\title{
The Patronage Effect: \\ Civil Service Reforms, Job-Seeking, and State Formation in Victorian Canada
}

by

\section{David Banoub}

A thesis submitted to the Faculty of Graduate and Postdoctoral Affairs in partial fulfillment of the requirements for the degree of

Doctor of Philosophy

in

History with Specialization in Political Economy

Carleton University

Ottawa, Ontario

(C) 2013

David Banoub 


\begin{abstract}
Patronage, in the mid- and late-nineteenth century, was central to Canadian politics. This period also witnessed a series of debates concerning the civil service and a range of reforms that attempted to eliminate patronage. This dissertation argues that, more than debates about administration and appointments, these were also struggles over how to construct the ideal civil servant and civil service. These were highly political issues that were beset by processes of inclusion and exclusion, especially with respect to gender, class, and race. In short, these were debates about the many facets of liberal governmentality and state formation in early modern Canada.

This dissertation also analyzes letters to federal politicians asking for appointments. Among other things, these documents expressed a range of opinions on how the bureaucracy should be managed, staffed and constructed. Letters asking for patronage also demonstrated how aspiring public servants understood and expected the appointment process to work. These letters reflected what type of people should have access to the civil service, and what type of people the applicants thought they were. As such, they informed and were themselves informed by broader political and administrative debates. These politics of Canadian patronage, I argue, were central to the everyday processes of state formation.
\end{abstract}




\section{Acknowledgements}

This dissertation would not have been possible without the staff, faculty, and intellectual climate at Carleton's Department of History and Institute of Political Economy. The opportunity to participate in a range of coursework, conferences, and discussions contributed to, changed, and sharpened my thinking about history, theory, and politics. The department's administrative team - Dr. Dominique Marshall, Dr. Jennifer Evans, Dr. James Miller, Joan White, Regina Aulinskas, and Irene Sanna - and Donna Coghill at the Institute all deserve thanks for making Carleton's bureaucracy always seem rational and never like an iron cage.

Special thanks to my supervisor, John C. Walsh, whose friendship, mentorship, and advice have been invaluable in developing my work, thinking, and teaching. His guidance transformed what seemed like an impossible amount of work into a manageable task. His unflagging enthusiasm for this project was contagious and made even the difficult work of revising, improving and editing an exciting process. Most importantly, John always reminded me of why I wanted to be a historian.

My examination committee, Professors Ian Radforth, Peter Hodgins, Bruce Curtis, and Dominique Marshall, provided generous thoughts, advice, and productive criticisms for how to improve this work. Drs. Marshall and Curtis were both kind enough to direct me in a reading course on state formation, as were Dr. Blair Rutherford and Dr. Cristina Rojas. The influence of these readings and meetings is demonstrated throughout this entire dissertation. It was also in one of these sessions that Dr. Curtis suggested this dissertation's title. 
Funding for this project was generously provided Carleton's Department of History, the Faculty of Arts and Social Sciences, and the Faculty of Graduate Studies and Postdoctoral Affairs. In addition to departmental funding, I was aided by the Carleton University Academic Staff Association Bill Jones Award, an Ontario Graduate Scholarship, and a Social Science and Humanities Research Council Doctoral Award. Research Assistantships for John Walsh and Bruce Curtis, and Teaching Assistantships also contributed to completing this project.

One of the pleasures of graduate studies was the sense of friendship and debate with my colleagues in the History Graduate Students' Association. I would especially like to thank David Tough, Jess Dunkin, Sara Spike, Brian Foster, and Susan Joudrey, all of whom were critical, thoughtful, and encouraging as the situation demanded. Sharing research and ideas with them in lectures and in living rooms, over coffees and beers, has been one of the best parts about my time at Carleton. Furthermore, teaching with Sara and Dave taught me lessons well beyond the scope of our courses.

My family and friends have also been unwaveringly supportive throughout my graduate studies. My friends have been especially kind in listening to me think through obstacles, and in helping me sometimes forget the world of civil service reform and patronage. I would like to thank my parents, Joseph and Judy Banoub, both biochemists, for being understanding when I told them I wanted to study history, and for never making me question that decision. Part of their acceptance was likely a result of the unconditional support they, and I too have, received from my grandparents, Robert Miller, Shirley Miller, Irma Stiers, and Habib Banoub Daoud (1918-2012). My brother, Daniel, and my sister, Kathryn, share the strange experience of being arts and humanities students in a 
family of scientists. They have both always pushed me to make my thinking more ambitious and my writing more precise.

Finally, my partner, Melanie Sturk, has lived with this dissertation as long as I have. For that whole time she has been thoughtful, understanding, and supportive. She never doubted me, or this work, and it is her confidence and partnership that has allowed me to complete this project. 
$\begin{array}{ll}\text { Abstract } & \text { ii }\end{array}$

$\begin{array}{ll}\text { Acknowledgements } & \text { iii }\end{array}$

Table of Contents vi vi

List of Illustrations _ vii

Chapter 1: Introduction 1

Part One: Debating, Constructing, and Regulating the Civil Service, 31 1867-1892

Chapter 2: 'The greatest possible public as well as party service:' Patronage, $\quad 32$ Politics and Rhetorics of Reform, 1867-1882

Chapter 3: A Question of Public Import: Partisanship, Public Men, and the 78 Kingsford-Langevin Affair

Chapter 4: 'An immense waste of power:' The 1891-92 Royal Commission and 106 the Civil Service's Regulation and Management

Part Two: Asking for Appointment: Patronage Letters, 1856-1896 150

Reading and Writing Patronage: A Social-Intellectual History 151

Chapter 5: Constructing Public Authority: Communities, the Public, and 156 Patronage Networks

Chapter 6: The Bureaucratic Body 196

Chapter 7: Desiring a Position: Emotions and Patronage 227

$\begin{array}{ll}\text { Chapter 8: Conclusion } & 257\end{array}$

$\begin{array}{ll}\text { Bibliography } & 265\end{array}$ 


\section{List of Illustrations}

7.1 Handwriting Sample, R.S. Bennison to Samuel Leonard Tilley, 1859230

7.2 Handwriting Sample, R.S. Bennison to Samuel Leonard Tilley, $1859 \quad 231$ 


\section{Chapter 1}

\section{Introduction}

"The bureaucracy is not a closed system; it is this that makes it a world instead of a thing. "1

David Foster Wallace, The Pale King, 2011

In 2011, Jason Kenney, the Conservative Citizen and Immigration Minister, responded to accusations of patronage appointments in his department by "producing a longer list of past Liberal patronage appointments." An editorial in the National Post was critical of this approach, lamenting that while "[y] ounger readers may not remember, but it is true nonetheless, that Mr. Kenney's partners in politics used to oppose patronage, full stop." "2 These accusations and evasions regarding patronage were not new tactics. The uses, defenses, and criticisms of patronage are long recurring themes in Canadian political debates. Given that this was a piece of contemporary political commentary, the Post editorial did not explore this long history.

In 2008, the Public Service Commission of Canada (PSC) produced a history of its first one hundred years. It described its work as "based on a century-old tradition of protecting public service appointments from political interference and ensuring a professional, non-partisan public service."3 The pamphlet includes a three-paragraph section on the nineteenth century, simply titled "Background." These paragraphs describe the main changes that occurred from the 1857 Act for Improving the Organization and Increasing the Efficiency of the Civil Service of Canada, the 1868 Canada Civil Service Act, and the 1882 Civil Service Act. It treats these pieces of legislation as starting steps

\footnotetext{
${ }^{1}$ David Foster Wallace, The Pale King (New York: Little Brown and Co., 2011), 86.

${ }^{2}$ Chris Selley, "Scandal-plagued Tories become the New Liberals," National Post, 7 December 2011.

${ }^{3}$ Public Service Commission of Canada, The 100 Years of the Public Service Commission of Canada, 1908-2008 (Ottawa: Public Service Commission of Canada, 2008), 4.
} 
towards the more successful reforms of the twentieth century. The section explains that “[t]oday's Public Service Commission is the legitimate heir to the civil service reform movement initiated in the $19^{\text {th }}$ century to create an independent, professional public service in which patronage and its associated corruption had no place." ${ }^{4}$ As the National Post editorial above suggests, this overstates the PSC's success in eliminating the widespread use of patronage. More problematically, this accepts the terms 'independent' and 'professional' in the nineteenth-century legislation as self-evident. In fact, these were highly contested ideas throughout the era.

This dissertation is a study of civil service reform, patronage, and job-seeking in the mid- to late-nineteenth century. During this time, the service expanded. Given the irregularities in departmental and colonial record-keeping prior to the reforms of the 1880 s, it is difficult to know the precise number of employees in the service. Compiling from "detailed and not always consistent figures," J.E. Hodgetts suggests that, in 1867, there 2,660 civil servants in across Canada, with 255 of them working in Ottawa. ${ }^{5}$ Ken Rasmussen provides a slightly different number, suggesting that at Confederation there were 264 employees in Ottawa, mostly doing clerical work. ${ }^{6}$ Despite a relatively sluggish economy in the decades after Confederation, the civil service continued to grow in this period. There were 551 civil servants in Ottawa in 1881, and 3,300 permanently

\footnotetext{
${ }^{4}$ Ibid., 4.

5 J.E. Hodgetts, The Canadian Public Service: A Physiology of Government (Toronto: University of Toronto Press, 1973), 89, 111; J.E. Hodgetts, Pioneer Public Service: An Administrative History of United Canada, 1841-1867 (Toronto: University of Toronto Press, 1955), 36. Hodgetts' also notes that there the United Canada there were equal numbers of Francophone and Anglophone civil servants. After Confederation, Francophones became a minority. Hodgetts, The Canadian Public Service, 35.

${ }^{6}$ Ken Rasmussen, "Administrative Reform and the Quest for Bureaucratic Autonomy: 1867-1918," Journal of Canadian Studies 29, 3 (1994), 47-49.
} 
employed under the Civil Service Act in $1892 .{ }^{7}$ Rasmussen also notes that government activity grew dramatically after the immigration and manufacturing booms of 1896; by 1900, there were 4,000-5,000 employees in Ottawa, and 38,000 across Canada. ${ }^{8}$

Throughout this period, then, most civil servants were located in cities and towns across the country with only a fraction of them (roughly 10-15 percent depending on the specific year) working in Ottawa.

This same period was when civil service reforms were debated and implemented, albeit unevenly. In contrast to the story that the PSC tells about itself, these reforms and debates did more than simply lead to the twentieth-century institutions along some unbroken line of professionalization and independence. Rather, the politics of change (and lack thereof) of the second half of the nineteenth century need to be understood historically, on their own terms. Debates about the civil service were more than debates about administration, record-keeping, and the appointment process. They involved imagining the public, political service and reward, and what type of person should be a civil servant. These were highly political issues that were beset by processes of inclusion and exclusion, gender, class, and race. In short, these debates were about the many facets of liberal governmentality in early modern Canada. They were not merely about how to manage a country or how to consolidate political power, but rather about what type of political systems were necessary. As we shall also see, these debates mattered to both politicians and the population whom they attempted to represent and govern.

\footnotetext{
${ }^{7}$ Hodgetts, The Canadian Public Service, 158; Canada, Parliament, Sessional Papers of the Dominion of Canada, vol. 11, $7^{\text {th }}$ Parliament, $2^{\text {nd }}$ Session (Ottawa: S.E. Dawson, 1892), 16C-xv. This number is slightly misleading, as many 'temporary' clerks were also hired and were not affected by the Civil Service Act. A wide range of workers were grouped in this temporary class, with salaries ranging from $\$ 1 /$ day to $\$ 4,500 /$ year. Parliament, Sessional Papers, 1892, 16C-xvi.

${ }^{8}$ Rasmussen, "Administrative Reform and the Quest for Bureaucratic Reform," 49.
} 


\section{Historiography of Patronage}

Traditionally historians have had little to say about patronage, seeing it only as corruption. This is especially true of traditional Canadian nationalist historians, who were interested in building a Canadian identity. ${ }^{9}$ In contrast, amongst political scientists, anthropologists and sociologists, a rich international literature on patronage (or clientelism) developed in the 1970s. These early debates are summarized in the collection Friends, Followers and Factions: A Reader in Political Clientelism. ${ }^{10}$ These studies focused on the workings of patronage systems - how patronage affected social, political, and economic relationships - in Southeast Asian, African, and Latin American examples. Carl H. Landé's introduction to the collection defines patron-client relations as unequal partnerships, based on the exchange of favours. These relationships are unequal because the patron has more wealth and power. Although they may reflect corruption, Landé suggests that these relationships may also serve to develop common community goals, by making the "private end-goals of the patron the intermediate goals of the clients." 11 Landé further notes that patron-client relationships are social networks, which foster connections between people and help to develop an inclusive sense of

\footnotetext{
${ }^{9}$ Biographers are particularly guilty of this. Donald Creighton's famous two-part biography of John A. Macdonald does not address patronage. Donald Creighton, John A. Macdonald, vol.1-2 (Toronto: The MacMillan Company of Canada, 1952-1955). Creighton, however, is not alone. Alaistair Sweeny's 1976 biography of George-Etienne Cartier has no mention of the spoils system. Alastair Sweeny, GeorgeEtienne Cartier (Toronto: McClelland and Stewart, 1976). P.B. Waite's 1985 biography of John Thompson mentions patronage in passing, but only to underscore Thompson's distaste for a corrupt system. P.B. Waite, The Man from Halifax: Sir John Thompson, Prime Minister (Toronto: University of Toronto Press, 1985). This trend is not limited to nationalist historians; Brian Young's biography of Cartier does mention patronage, and notes Cartier's role and interest in it. Young still does not examine patronage as a system, but rather as further evidence of Cartier's corruption and self-interest. Brian Young, George-Etienne Cartier: Montreal Bourgeois (Montreal and Kingston: McGill-Queen's University Press, 1981).

${ }^{10}$ Steffen W. Schmidt, Laura Guasti, Carl H. Landé and James C. Scott, eds., Friends, Followers and Factions: A Reader in Political Patronage (Berkeley: University of California Press, 1977).

${ }^{11}$ Carl H. Landé, "Introduction: The Dyadic Basics of Clientelism," in Schmidt, et al., Friends, Followers and Factions, xxi.
} 
community. ${ }^{12}$ Sociologist Vincent Lemieux's comparative overview of patronage, Le Patronage politique, similarly argues that "le patronage politique renforce toujours la connexité d'une société."13 His comparative approach enables him to highlight the different types of connections in different societies. In largely homogenous societies, like Quebec or communities of the Mediterranean, patronage has historically been a local matter and the emphasis on party loyalty and the centralization of political control. In the United States, by contrast, patronage has historically been used to decentralize federal power and give heterogeneous groups a stake in politics. American machine politics gave power and authority to communities while simultaneously linking new immigrants to the federal state. $^{14}$

The best-known histories of Canadian patronage draw from these debates over clientelism, social connections, and party politics. Gordon Stewart's The Origins of Canadian Politics examines the effects of patronage from the top-down focusing on the development of Canadian political parties and patronage's lasting imprint on the country's political landscape. He situates the origins of Canadian politics in the 1840s' debates over responsible government and the development of party government, a period characterized by the "intense use of patronage." 15 According to Stewart, Canadian politics differed from British and American because of the legitimatization of patronage.

\footnotetext{
12 Ibid., xxxii.

${ }^{13}$ Vincent Lemieux, Le Patronage politique: une étude comparative (Québec: Les presses de l'Université de Laval, 1977), 217.

${ }^{14}$ Ibid., 129-133, 154-155.

${ }^{15}$ Gordon T. Stewart, The Origins of Canadian Politics: A Comparative Approach (Vancouver: University of British Columbia Press, 1986), 88. The differences between the British and Canadian treatments of patronage are also explored by David E. Smith, "Patronage in Britain and Canada: An Historical

Perspective," Journal of Canadian Studies, 22:2 (1987), 34-54. Like Stewart, his comparisons suggest that in the early-nineteenth century patronage was removed from British public life. In that same period "Canada moved in the opposite direction and transferred the patronage directly in the hands of colonial leaders who made administration an extension of politics" (40).
} 
S.J.R. Noel's 1990 study of patron-client relationships in nineteenth-century Ontario similarly dealt with the functioning of party politics. Noel, a political scientist, explicitly draws from the clientelism literature. He traces the transition from direct patron-client relationships in the first part of the nineteenth-century to brokerage clientelism after the 1830s. He describes brokerism as the

answer to the inherent limitation of simple dyadic clientelism: its weak or non-existent horizontal links between patrons. By pooling the surplus capital of local patrons, and by adding to it capital from any external sources that might be available, brokers would be able to put together the deals that would make possible developments more ambitious than any previously undertaken, except by government. ${ }^{16}$

This early transition, suggests Noel, was the groundwork for Ontario's political culture. Confederation marked an important milestone and caused the elites to adapt to the new political realities, but politics remained localized and based on clientelism and brokerism. Alan Gordon explores this relationship between patrons, brokers and clients in an article on the career of Edmund Bristol, the Member of Parliament for Centre Toronto in the early twentieth century. Bristol, according to Gordon, was a "shrewd dispenser of patronage" and achieved success through "the science of connection. ${ }^{, 17}$ In his riding Bristol balanced appointments between the working class, new immigrants, and the wealthy. He also navigated political relationships between federal, provincial and municipal politics. Gordon suggests that relying on the continued importance of personal connections help to ease the transition from nineteenth-century patronage politics to the professionalism of the twentieth century. ${ }^{18}$ For French Canada, Gilles Paquet and JeanPierre Wallot argue that, at the turn of the nineteenth century, control of the patronage

\footnotetext{
${ }^{16}$ S.J.R. Noel, Patrons, Clients, Brokers: Ontario Society and Politics, 1791-1896 (Toronto: University of Toronto Press, 1990), 116.

${ }^{17}$ Alan Gordon, "Patronage, Etiquette, and the Science of Connection: Edmund Bristol and Political Management, 1911-1921." Canadian Historical Review, 80:1 (1999), 5, 6.

${ }^{18}$ Ibid., 32.
} 
system was one of the most important objects of conflict between the British authorities and the Parti canadien. Through quantitative analysis they demonstrate an ethnic bias in patronage appointments in early colonial government, with Francophones receiving fewer appointments and generally receiving lower wages in the late-eighteenth and earlynineteenth centuries. ${ }^{19}$

A popular source for Canada's history of political patronage is Jeffrey Simpson's Spoils of Power. His aim is ambitious: "to pull the thread of patronage through the whole broad cloth of Canada's political experience. ${ }^{, 2} \mathrm{He}$ outlines the use of patronage to reward allies and entrench political power from John A. Macdonald to Brian Mulroney. A well-known journalist, Simpson's survey is the source of most Canadians' understandings of the role of political patronage. Simpson notes although patronage is corruption, it is also an effective political tool. He states with some approval that "patronage, whatever its costs, has done its bit for national integration and political stability." 21

In addition to political, class, and linguistic issues, Ken Rasmussen, in “Administrative Reform and the Quest for Bureaucratic Autonomy: 1867-1918,” stressed the role of senior civil servants in the transition from patronage to professionalization. This cadre, he argues, "wished to overcome patronage politics in order to strengthen the regulatory and extractive capacities of the state, while at the same time promoting the public service as an attractive middle-class profession. ${ }^{22}$ Central to this project was separating politics and administration, which, Rasmussen highlights, nineteenth-century

\footnotetext{
${ }^{19}$ Gilles Paquet et Jean-Pierre Wallot, Patronage et pouvoir dans le Bas-Canada (1794-1812) (Montreal: Les presses de l'Université du Québec, 1973), 106, 133.

${ }^{20}$ Jeffrey Simpson, Spoils of Power: The Politics of Patronage (Toronto: Harper Collins, 1988), 2.

${ }^{21}$ Ibid., 16.

${ }^{22}$ Rasmussen, "Administrative Reform and the Quest for Bureaucratic Autonomy,” 46.
} 
reformers saw as "essential if the civil service was to serve the objective value of efficiency."${ }^{23}$ Robert A.J. McDonald examines this same process at a provincial level. Outlining the "ongoing rhythm of patronage and reform that marked British Columbia's early administrative history," he traces the transition from a small, decentralized, informal system in the 1870 s, to a modern, autonomous system in the 1940 s. $^{24}$ Refreshingly, these works discuss the efforts of civil servants in the search for professional autonomy. They incorporate the struggles of those attempting to reform the civil service. Writing from a public policy position, however, Rasmussen tends to overstate the separation of politics and administration. ${ }^{25}$ Resulting from this policy interest, he does not explore the quotidian politics of administration.

The histories of Canadian patronage convincingly highlight its importance in political systems, party, and class politics. These works do not, however, address questions of culture - of how federal patronage was made meaningful throughout society. Throughout this dissertation, I am interested in a still overlooked component: the people asking for jobs and potentially making up the state apparatus. These public employees and would-be public employees interacted with a range of ideas about the civil service and about the ideal civil servant.

\footnotetext{
${ }^{23}$ Ibid., $52 .$.

${ }^{24}$ Robert A.J. McDonald, “The Quest for 'Modern Administration': British Columbia’s Civil Service, 1870s to 1940s," BC Studies, 161 (Spring 2009), 22. He explains that since the province "remained a geographically fractured province of local communities into the 1940s," patronage continued to work (33). ${ }^{25}$ The "politics-administration dichotomy" is an important theme in much public policy analysis. It is explored by Peter Aucoin and Donald J. Savoie, "The Politics-Administration Dichotomy: Democracy versus Bureaucracy" in O. P. Dwivedi, Tim Mau, and Byron M. Sheldrick, "Canadian Public Administration Transition: An Introduction," in Dwivedi, Mau, and Sheldrick, eds., The Evolving Physiology of Government: Canadian Public Administration in Transition (Ottawa: University of Ottawa Press, 2009), 97-117; David Rosenbloom, "The Politics-Administration Dichotomy in U.S. Historical Context," Public Administration Review, 68:1 (2008), 57-60.
} 
In exploring how patronage was conceived and requested, the question of regionalism is another aspect to consider. In a mid-1970s article, Noel used the language of brokerism and clientelism to compare contemporary Atlantic, Central, and Western Canada. He found that Atlantic Canada and Quebec remained in the elementary stages, of face-to-face local clientelism; western Canada was in the secondary stage, where brokers mediated between political machines and local appointments; Ontario was in the third stage, which was marked by bureaucratic organizations overtaking local notables and party officials. ${ }^{26}$ Less comparative work has been done on the nineteenth century.

Of the works mentioned so far, Simpson's is the only study to consider patronage across Canada rather than focussing on a specific region. Stewart is particularly frank about ignoring the Maritime and Western Canadian provinces' role in the federal patronage system. He acknowledges that these regions had patronage systems, but explains that "the case made here, however, is that the Maritime and Western provinces, while they had an impact on post-1867 government formation and parliamentary alignments and while they certainly forced attention to particular issues, did not make a fundamental alteration in the political culture already established in the pre-1867 Canada." He concludes, rather glibly, that "on this matter Maritimers at least can console themselves, as they so often do, with the thought that Canadians are to blame for everything." ${ }^{27}$ Stewart's emphasis on party politics leads him to locate the origins of Canadian politics in Ontario and Quebec. That may be true, but as Philip Buckner has argued, patronage was also important and often sought-out in Atlantic Canada because

\footnotetext{
${ }^{26}$ S.J.R. Noel, "Leadership and Clientelism," in David Bellamy, Jon Pammett and Donald Rowat, eds., The Provincial Political Systems: Comparative Essays (Toronto: Methuen, 1976). Drawing from this work, Drawing Nelson Wiseman suggests that "patronage may be associated with distinctive regional cultures." Nelson Wiseman, In Search of Canadian Political Culture (Vancouver: UBC Press, 2007), 130.

${ }^{27}$ Stewart, The Origins of Canadian Politics, 7.
} 
there were fewer public positions there than in central Canada. Job-seekers in the Maritimes, Buckner suggests, followed the Central Canadian example. ${ }^{28}$

In exploring sources from New Brunswick and Nova Scotia, as well as from Ontario and Quebec, this dissertation identifies how and under what conditions the geographies of patronage mattered. This is especially so when it considers the relationship between patronage and the "outside service," that is positions that were held outside Ottawa in local communities. Chapter Five explicitly focuses on how "the local" and "community" in these places were fundamental to the political culture of patronage revealed in the letters. In other chapters, a variety of sources indicate that spatial and geographic concerns were included in political and administrative thinking about civil service, labour, and their relations with both the public and government.

\section{Histories of the Civil Service}

Debates over patronage in the mid- and late-nineteenth century took place in an era of civil service reform. To understand this, histories of the civil service are useful. The starting point for much Canadian history of the civil service is the work of J.E. Hodgetts. In Pioneer Public Service, he outlines the Province of Canada's administrative history from 1841 to $1867 .{ }^{29}$ His The Canadian Public Service pursues a history of the public service from Confederation to 1970. Hodgetts understood his work as a long-term "historical-analytical survey, mapping the profile and physiology of the public service." 30

\footnotetext{
${ }^{28}$ Philip Buckner, "The 1870s: Political Integration," E.R. Forbes and D.A. Muise eds., The Atlantic Provinces in Confederation (Toronto: University of Toronto Press, and Fredericton: Acadiensis Press, 1993), 56. E.R. Forbes explores a similar dynamic of Maritimers attempting to get better access to federal relief and welfare programs in the late 1920s and 1930s. He suggests these actions and the letters they wrote to politicians asking for aid were related to "the cumulative development of regional disparity in Canada." E.R. Forbes, Challenging the Regional Stereotypes: Essays on the $20^{\text {th }}$ Century Maritimes (Fredericton: Acadiensis Press, 1989), 170-171.

${ }^{29}$ Hodgetts, Pioneer Public Service.

${ }^{30}$ J.E. Hodgetts, The Canadian Public Service, 341.
} 
He connects the evolution and expansion of the Canada's public service to the physical, economic, technological, and cultural contexts in which it formed. For Hodgetts, the nineteenth-century Canadian public service had to overcome a number of contextual challenges: relatively weak infrastructure; distance; and linguistic tensions between French and English Canada.

Hodgetts, who in 1946 taught the first Canadian undergraduate course in public administration at Queen's University, inspired a range of scholars to investigate what he later called the "the nitty-gritty of organization and methods." ${ }^{31} \mathrm{He}$ has been referred to as the "the father of the study of Canadian public administration." "32 His influence was made readily apparent in a 1982 festschrift, The Administrative State in Canada. ${ }^{33}$ The essays in this collection are largely interested in institutional questions - in the phenomena "by which state institutions influence many aspects of the lives of citizens, especially those aspects which relate to the economy and social dimensions." 34 These essays examine the growth of federal and provincial governments, regulatory and communicative practices, and how twentieth-century state officials are held accountable. Most relevant to this dissertation is the chapter by Roch Bolduc and James Iain Gow, "Environment and Administration: Quebec, 1867-1980." They argue that during this period political, religious, economic and cultural forces controlled Quebec's bureaucracy. The forthcoming chapters in this dissertation similarly argue that the rhetoric of

\footnotetext{
${ }^{31}$ J.E. Hodgetts, "Review of The Ottawa Men by Jack Granatstein,” in International Journal, $37: 4$ (1982), 637.

${ }^{32}$ O. P. Dwivedi, Tim Mau, and Byron M. Sheldrick, "Canadian Public Administration Transition: An Introduction," in Dwivedi, Mau, and Sheldrick, eds., The Evolving Physiology of Government, xxxix.

${ }^{33}$ O.P. Dwivedi and John Meisel, eds., The Administrative State in Canada: Essays in Honour of J.E. Hodgetts (Toronto: University of Toronto Press, 1982).

${ }^{34}$ V. Seymour Wilson and O.P. Dwivedi, "Introduction," in Dwivedi and Meisel, eds., The Administrative State in Canada, 5.
} 
patronage drew from what Bolduc and Gow call this 'ecology' of historical context. ${ }^{35}$

Despite their historical approach, Bolduc and Gow are more interested in contemporary issues. Suggesting because of this outside control, the bureaucracy was in a relatively weak position to reform, they indicated that following the Quiet Revolution of the 1960s Quebec's administration had undergone "prodigious growth" and "had been given a role of managing and orienting social and economic life in the name of rationality." 36 This emphasis on contemporary management and policy is present throughout the collection. ${ }^{37}$

This concern with contemporary policy is present in The Evolving Physiology of Government, a second collection published in honour of Hodgetts in 2009, following a conference celebrating his ninetieth birthday. The essays in this collection explore the transformation of the PSC throughout the twentieth century. The PSC, the editors suggest, "has served us well. It has given dependability and reliability to the institutions of governance, and is has answered the challenge by shifting its orientation from a homogeneous administrative system to a multifaceted administrative culture." 38 The chapter that most addresses the nineteenth century is Ken Rasmussen and Luc Juillet's "The Origins of Merit in Canada," adapted from their Defending a Contested Ideal: Merit and the PSC of Canada. ${ }^{39}$ Rasmussen and Juillet explore the politicized history of the

\footnotetext{
${ }^{35}$ Roch Bolduc and James Iain Gow, "Environment and Administration: Quebec, 1867-1980," in Dwivedi and Meisel, eds., The Administrative State in Canada, 31.

${ }^{36}$ Ibid., 57. It should also be noted that this article, to its credit, places the Quiet Revolution and bureaucratic reforms in anti-colonial context. It introduces questions of race and language to those of administration. This is a fruitful avenue for exploration, and one whose politics is taken up in Sean Mills, The Empire Within: Postcolonial Thought and Political Activism in Sixties Montreal (Montreal and Kingston: McGill-Queen's University Press, 2010)

${ }^{37}$ The introduction emphasizes this as well: "all the essays implicitly concerned with the need to build a democratic theory which grapples seriously with the realities of the administrative state - one which explains how 'adequate public control' ought to be redefined in the light of modern conditions." V. Seymour Wilson and O.P. Dwivedi, "Introduction," 12.

${ }^{38}$ Dwivedi, Mau, and Sheldrick, "Canadian Public Administration Transition: An Introduction," xxxv.

${ }^{39}$ Ken Rasmussen and Luc Juillet, The Origins of Merit in Canada" in Dwivedi, Mau, and Sheldrick, eds., The Evolving Physiology of Government: Canadian Public Administration in Transition; Luc Juillet and
} 
concept of merit in the PSC commission. They argue that the idea of merit itself has a history, since it was contested throughout the twentieth century. The term, they explain, "has been an uneasy proxy for different sets of values and aspirations that are themselves not easy to either define or reconcile. ${ }^{, 40}$ While their book focuses on the twentieth century, Rasmussen's and Juillet's 2009 article explores the idea of merit in the nineteenth century. They describe appointment based on merit as the solution to "the corrupt patronage-riddled bureaucracy" and the tool necessary to "transform it into a dedicated professional body mindful on the public interest and capable of both supporting government decision-making and informing ministers about their proper roles and responsibilities within the constitutional system. ${ }^{41}$ To reformers they explain that merit was the essential principle to separate "administration from politics," which would make "public administration more efficient by ensuring the partisans who were appointed were capable of handling the nonpolitical nature of the majority of their tasks. ${ }^{, 42}$ Exploring the reforms of the nineteenth century is a welcome intervention in a literature that mostly emphasizes twentieth-century policy battles. Like the PSC's own pamphlet, their focus on the debates over merit, however, leads them to be less critical of terms such as 'political,' 'partisan,' 'efficiency' - all of which, we shall see in Part One of this dissertation, were also contested in this period. Similarly, even though their approach is historical, they write that the reforms of 1882 begin "an established pattern of administrative reform, that despite interruptions, would continue to accelerate until

Ken Rasmussen, Defending a Contested Ideal: Merit and the PSC of Canada, 1908-2008 (Ottawa: University of Ottawa Press, 2008).

${ }^{40}$ Juillet and Rasmussen, Defending a Contested Ideal, 7.

${ }^{41}$ Rasmussen and Juillet, The Origins of Merit, 74-75.

${ }^{42}$ Ibid., 81. 
1908." "43 They do not explore that pattern in detail, passing quickly to the twentieth century, when, they suggest, Canadians were more accepting of merit, governmental activity, and independence in the civil service. ${ }^{44}$

The institutional and public policy approaches largely concern contemporary issues. Even when their work is historical, it tends to treat the nineteenth century as a precursor to more successful reforms that come later. Michael Piva's work offers an interesting contrast to this, as he provides close analysis on a single act, the Civil Service Act of 1857. In "Debts, Salaries and Civil Service Reform in Pre-Confederation Canada," he argues that these reforms were primarily economic, not political nor bureaucratic. ${ }^{45}$ This same act is also examined in his article "Getting Hired: The Civil Service Act of 1857." In this work, Piva analyses the period between 1857 and 1861, when the government of the Province of Canada instituted an exam to govern appointments to the civil service, and focuses on middle-class formation. Piva uses the employment histories, medical certificates and references applicants provided to suggest what types of people took the exam, concluding that while their age varied, they were largely from the urban middle class, and many of the applicants already held permanent salaried positions. ${ }^{46}$ One of Piva's claims is that the influence of patronage in the civil service was exaggerated in

\footnotetext{
${ }^{43}$ Ibid., 82 .

${ }^{44}$ Ibid., 87.

${ }^{45}$ He writes, "[n]o doubt the Civil Service Act of 1857 represented a critical development in state formation, yet the primary motivation, as with so many other administrative reforms introduced during the union period, remained fiscal. "Michael J. Piva, "Debt, Salaries and Civil Service Reform in PreConfederation Canada," National History, 1 (1997), 135. Piva positions this article as revising a state formation approach, which, he claims, over emphasizes ideology and bureaucratic reforms. Piva did not identify what authors or titles he was revising. In "Getting Hired," however he does note that the authors in Colonial Leviathan, particularly Ian Radforth's essay, "Sydenham and Utilitarian Reform," in Allan Greer and Ian Radforth, eds., Colonial Leviathan: State Formation in Mid-Nineteenth-Century Canada (Toronto: University of Toronto Press, 1992), 64-102, overstate the importance of political ideas at the expense of financial ones. Michael Piva, "Getting Hired: The Civil Service Act of 1854," Journal of the Canadian Historical Association, 3:1 (1992), 106.

${ }^{46}$ Piva, "Getting Hired," 106-107, 117. These practices also suggest the type governmentalizing state practices explored in Bruce Curtis's work. Some of this work and these practices are discussed below.
} 
this period. He acknowledges that party considerations "governed the appointments of judges, J.P.s, magistrates, coroners and others" but "analysis of applications, examinations, and appointments to the inside service yields almost no evidence of patronage." 47 This is perhaps true of the short four-year period in Piva's study. As the debates and commissions of the late-nineteenth century show, however, patronage continued to be significant in the civil service throughout the late-nineteenth century.

In much of this work on the history of the civil service, civil servants themselves are largely absent. Rasmussen’s article, “Administrative Reform and the Quest for Bureaucratic Autonomy," discussed above, adds the view of senior civil servants. Another text that attempts to do this is Bill Doherty's Slaves of the Lamps, which aims to be a survey of the federal civil service focusing on the employees. In his introduction he states, "one fact is certain; as poorly paid and treated as they were, most of those early employees were proud to be known as 'Dominion civil servants."' He goes on to quote from Hodgetts's Pioneer Public Service, stressing that "these administrative pioneers deserve better of us than oblivion. ${ }^{, 48}$ Doherty, however, provides only a single chapter on the nineteenth century. The subsequent chapters are largely a survey of institutional and administrative changes and of the organizing activities of Frank Grierson, who was the librarian for the Civil Service Commission, and, according to Doherty, "a man out of his time," since he fought for bureaucratic autonomy in a period when others "would not dare." 49

\footnotetext{
${ }^{47}$ Ibid., 125.

${ }^{48}$ Bill Doherty, Slaves of the Lamp: A History of the Federal Civil Service Organizations, 1865-1924 (Victoria B.C.: Orca Books, 1991), Introduction (unnumbered page).

${ }^{49}$ Ibid., 492.
} 
In focusing on the career of an important bureaucrat, Doherty is part of a tradition of Canadian historiography on influential civil servants. Two important examples of this tradition are Jack Granatstein's The Ottawa Men and Douglas Owram's The Government Generation. Granatstein's monograph describes the efforts of a group of senior public servants, what he calls the "civil service Mandarins," as they attempted to meet internal and domestic policy challenges. ${ }^{50}$ Owram focuses on intellectual history, examining how an intellectual elite rose to prominence in the Canada's bureaucracy during the 1930s. Following the First World War and resulting from the growth of social science, Canadian intellectuals increasingly emphasized the importance of efficient planning, Keynesian economics, and the welfare state. ${ }^{51}$ Inspired by the examples of Granatstein and Owram, Barry Ferguson's Remaking Liberalism is another intellectual history of influential bureaucrats in the early twentieth century. Focusing on Adam Shortt, O.D. Skelton, W.C. Clark, and W.A. Mackintosh, all Queen's political economists turned civil servants, Ferguson explores their attempts to apply political economic ideas to Canada's social and political issues. According to Ferguson, they drew "from their insights into human nature and political behaviour," in their attempts to "find the means to remake political institutions in the wake of expanding democracy., ${ }^{, 52}$

Of these works, Ferguson's is the most relevant to this study. Although he does not examine the debates on civil service reform in the late-nineteenth century, he does

\footnotetext{
${ }^{50}$ Jack Granatstein, The Ottawa Men: The Civil Service Mandarins, 1935-1957 (Toronto: Oxford University Press, 1982). This term and this generation is also taken up by Kenneth Kernaghan and T.H. McLeod, "Mandarins and Ministers in the Canadian Administrative State," in Dwivedi and Meisel, eds., The Administrative State in Canada, 17-30.

${ }^{51}$ Douglas Owram, The Government Generation: Canadian Intellectuals and the State, 1900-1945 (Toronto: University of Toronto Press, 1986).

${ }_{52}$ Barry Ferguson, Remaking Liberalism: The Intellectual Legacy of Adam Shortt, O.D. Skelton, W.C. Clark, and W.A. Mackintosh, 1890-1925 (Montreal and Kingston: McGill-Queen's University Press, 1993), 8.
} 
describe the construction of professionalism and the application of political economic ideas that will be taken up throughout the dissertation. These social scientists attempted to influence society, transferring some governing authority from politicians to professional bureaucrats. ${ }^{53}$ Ferguson places these scholars within the mainstream of British and American social sciences, showing how they drew from history and social science to make policy suggestions. ${ }^{54}$

\section{'A Spectacle of Corruption'}

There is a tendency in both the works on Canadian patronage and on the civil service to treat nineteenth-century patronage as either a precursor to the more developed political forms of the twentieth century or as an obstacle on the road to democratic reform. Reg Whitaker attributes this to the "tendency to moralize, to dismiss patronage as mere corruption or as a primitive anachronism whose passing should be hastened." 55 Whitaker's own work complicates this by exploring the class dynamics of patronage and bureaucratic reform. ${ }^{56}$ This moralizing is noticeable even in works that explore the contexts and logics of these political systems and institutions. Jeffrey Simpson states that "patronage is the pornography of politics, enticing to some, repulsive to others, justified as inevitable, condemned as immoral, a practice seldom consider fit for polite discussion. ${ }^{.57}$ Bill Doherty notes that in 1893 the "plague of patronage was still

\footnotetext{
${ }^{53}$ Ibid., 30 .

${ }^{54}$ Ibid., 54 .

${ }^{55}$ Reg Whitaker, Between Patronage and Bureaucracy: Democratic Politics in Transition," Journal of Canadian Studies, 22:2 (1987), 56.

${ }^{56}$ Albert Breton's article "Patronage and Corruption in Hierarchies," Journal of Canadian Studies, 22:2 (1987): 19-33, adds further nuance to this. Breton suggests that patronage is a feature universal feature of human organizations, but not necessarily corruption. The corrupt tendencies can be restrained by competition for these appointments. He notes that, when coupled with partisan politics, it tends to lead to corruption, however.

${ }^{57}$ Simpson, Spoils of Power, 6.
} 
burdening the civil service." ${ }^{58}$ Ferguson is more nuanced. He still describes "the practice of politics and government in post-Confederation Canada" as "a spectacle of corruption," but he also outlines the arguments that the Queen's political economists used to criticize this system ${ }^{59}$ Ferguson describes how Adam Shortt explained the system's survival on the willingness of the voters to accept it. Shortt's student, O.D. Skeleton argued that patronage was in fact "entrenched by those dominant interests - politicians and businessmen - who were most actively participating in politics and benefiting from it. $" 60$ In Defending a Contested Ideal, Juillet and Rasmussen share Skeleton's perspective, noting that "what stood in the way of the reform of the public service for the first forty years of Canadian history was the self-interest of the political parties, which did not want to relinquish their power to appoint partisans to the public service." ${ }^{, 61}$ As we will see in this dissertation, patronage did not only serve the political elites - what Juliet and Rasmussen call the "political masters" and "unscrupulous politicians who might try to pressure them into circumventing laws or disregarding standards of conduct in order to further partisan gains. ${ }^{" 62}$ Chapter Three and the examples throughout Part Two, suggest that the electorate, and, at times, professional public servants wanted patronage too.

In this dissertation, rather than treating patronage as corruption, I examine its logic, its support, and the rhetoric used to request and to decry it. Like Stewart and Noel, I treat these as historical questions about the period's political culture. The forthcoming chapters diverge from the existing literature, however, in that they explore the clients that supported this culture as well as the patrons. There are examples throughout the

\footnotetext{
${ }^{58}$ Doherty, Slaves of the Lamp, 17.

${ }^{59}$ Ferguson, Remaking Liberalism, 118.

${ }^{60}$ Ibid., 137.

${ }^{61}$ Juillet and Rasmussen, Defending A Contested Ideal, 20.

${ }^{62}$ Ibid., 2.
} 
dissertation of corruption, partisanship, and electioneering, but they are placed in their historical context and investigated for their rhetorical reasoning, rather than contrasted to more democratic and contemporary policy practices. Politicians and voters both actively engaged in the culture of patronage, and this culture, I argue, needs to be taken seriously. To nineteenth-century politicians, patronage was not a 'plague' or 'pornography'; it was central to politics and it was openly discussed. That the letters requesting patronage appointments are archived as political correspondence points to patronage's ordinariness and everydayness. Similarly, we should remember that after George-Étienne Cartier's death, John A. Macdonald and Hector Langevin purged his papers of evidence of corruptions and abuses of power; the letters regarding patronage remain. In contrast to railway politics, there was nothing shameful about the request for and allocation of patronage.

\section{State Formation, Governmentality, and the 'Language of Stateness'}

The relationships between politicians, administrators, and job-seekers were an ongoing series of negotiations. These negotiations took place in a social and political context whereby constructions of race, class, and gender became entrenched. To understand these negotiations and contexts, I draw from the literature on state formation. Philip Corrigan and Derek Sayer's The Great Arch is a work that entangles politics and culture. Focusing on England, they suggest state formation is cultural revolution, and "aim to go behind the 'idea of the state', to show it as a construction, to decode its 'message of domination'. ${ }^{\prime 63}$ Although remaining focused on political relations they also

\footnotetext{
${ }^{63}$ Philip Corrigan and Derek Sayer, The Great Arch: English State Formation as Cultural Revolution (Oxford: Basil Blackwell, 1985), 8. In exploring the construction of the state, Corrigan and Sayer build on the insights of Philip Abrams, "Notes on the Difficulty of Studying the State," Journal of Historical Sociology, 1:1 (1988), 58-89.
} 
explore the deepening moral and social regulation. Rather than positing political and class relations as natural, Corrigan and Sayer stress their historic and cultural specificity. They write that

neither the shape of the state, nor oppositional cultures, can be properly understood [without] the context of mutually formative (and continuing) struggle between them: in other words, historically. Too often these have been sundered. State forms have been understood within state formation's own universalizing vocabularies, without reference to what they are formed against. ${ }^{64}$

The processes through which dominant orders were established were not isolated; they depended on moral, intellectual, social and economic concerns. Mark Neocleous's Administering Civil Society similarly shows the interconnections of class interests and state formation. Like Corrigan and Sayer, he suggests that the category of the political is broader than the electoral and the parliamentary; the political must include social and economic relations, and, he stresses, "the mechanisms of administration." ${ }^{.55}$ Throughout his text Neocleous argues that state formation was rooted in struggle, and political administration was central in mediating these struggles. This is extremely relevant to the debates over the civil service that will be explored in Chapters Two and Four of this dissertation. These debates hinged on constructions of authority, democracy, corruption, gender, efficiency - all political issues. Both patronage and civil service reforms were struggles. Job-seekers were struggling to find work for themselves, while patrons and reformers were both struggling for control of the appointment process. All these issues involved the construction of what a professional civil service, and what an ideal civil servant, was and was not.

\footnotetext{
${ }^{64}$ Corrigan and Sayer, The Great Arch, 7.

${ }^{65}$ Mark Neocleous, Administering Civil Society: Towards a Theory of State Power (London: Macmillan Press, 1996), 91.
} 
Motivated by Marxist thought, the struggle in much state formation literature is class struggle. Neocleous reminds us nineteenth-century state formation, in England, at least, was also the "process whereby social and economic relations are transformed into the relations of private property, commodity production and wage-labour." 66 Corrigan and Sayer's emphasis on cultural revolution is more influenced by cultural history and postmodern theory. Throughout The Great Arch they focus on the relations between capitalism and state formation, but explore the economy as socially constructed. They write that "real world 'economies' exist only as historical forms of civilization, and in the case of capitalist economy state formation is crucial to their making and sustaining." The relationships between power, political independence and liberal individualism were crucial to the culture development of the English state. ${ }^{68}$ In addition to highlighting the interplay of ideas, wealth and power, The Great Arch's critique emphasizes gender relations. Women, the authors are careful to point out, were excluded from the category of the liberal individual. ${ }^{69}$ These twinned assumptions of gender and class are central to this dissertation, since debates on patronage were also debates about what it meant to be a political, public man.

There is a rich tradition on the relationships between state and society, politics and culture, in Canadian historiography. Much of the literature from the 1970s and 1980s

\footnotetext{
${ }^{66}$ Neocleous, Administering Civil Society, 91. Emphasis in original. Rianne Mahon likewise proposed a Marxist approach to studying public policy. She writes that the understandings of public policy processes should incorporate both class struggle and the relative autonomy of the state. In this view, the state can been seen as the "organizer of hegemony," and it functions as "the series of compromises which seek to win the consent of the subordinate classes to the capitalist system." Public policy, then can be understood as a one of the means of subordinating popular interests to those of the "hegemonic fraction." Rianne Mahon, "Canadian Public Policy: The Unequal Structure of Representation," in Leo Panitch, ed., The Canadian State: Political Economy and Political Power (Toronto: University of Toronto Press, 1977), 193194.

${ }^{67}$ Corrigan and Sayer, The Great Arch, 203.

${ }^{68}$ Derek Sayer also theorizes this relationship in his article "A Notable Administration: English State Formation and the Rise of Capitalism," The American Journal of Sociology, 97:2 (1992), 1382-1415. ${ }^{69}$ Corrigan and Sayer, The Great Arch, 36, 95.
} 
coalesced in the essays in Greer and Radforth's Colonial Leviathan. As they explain in the introduction, their contributors draw from social history to explore how the political shifts of 1830-1870 were related to the "to the constellations of agencies and officers sharing in the sovereign authority." ${ }^{, 70}$ These essays make important insights on a range of topics. For this dissertation, perhaps the most relevant are those of Lykke de la Cour, Cecilia Morgan and Mariana Valverde, on gender regulation in Canadian society. Proposing studying Canadian state formation through a gendered perspective, they identify the establishment of the bureaucracy and the centralization of the political apparatus as "masculinization of public power" which was accompanied by the "rigidification of gender divisions." $"$ These gender constructions and the entrenchment of masculine privileges were also central to administrative issues, and will be taken up throughout this dissertation.

Gender is one analytical category that helps understand state formation as cultural revolution. Governmentality - the art of government, and the "conduct of conduct" - is another. $^{72}$ This is the focus of Bruce Curtis's 2001 monograph, The Politics of Population. Exploring the politics of census-making in mid-nineteenth-century Canada,

\footnotetext{
${ }^{70}$ Allan Greer and Ian Radforth, "Introduction," in Greer and Radforth, eds., Colonial Leviathan: State Formation in Mid-Nineteenth-Century Canada (Toronto: University of Toronto Press, 1992), 10. Michel Ducharme's work follows in this tradition, exploring the role of philosophical ideas in the construction of state forms. In his article, "Penser le Canada," he examines the philosophical consequences of the crises of 1838-40, arguing that this period was important in Canadian history because it was marked by the hierachisation of liberalism and nationalism. In this hierarchisation, the rebels of 1837-38 were committed to protecting their language and religion, while also following ideas of British liberalism. Michel Ducharme, "Penser le Canada," Revue d'Histoire de l'Amérique Française, 56:3 (Winter 2001), 358. Ducharme takes this idea up again in 2010 monograph, arguing that intellectual ideas about rights and liberties were central state formation in colonial Canada. State institutions were made legitimate by their following liberal ideas. Michel Ducharme, Le concept de liberté au Canada à l'époque des Révolutions atlantiques, 1776-1838 (Montreal and Kingston: McGill-Queen's University Press, 2010), 11-12.

${ }^{71}$ Lykke de la Cour, Cecilia Morgan and Mariana Valverde, "Gender Regulation and State Formation in Nineteenth-Century Canada," in Greer and Radforth, eds., Colonial Leviathan, 163.

${ }^{72}$ Michel Foucault, "Governmentality," in Graham Burchell, Colin Gordon and Peter Miller, eds., The Foucault Effect: Studies in Governmentality (Chicago: University of Chicago Press, 1991), 102-103.
} 
Curtis argues that instituting a statistical mode of enquiry was central to processes of state formation. He notes that "as a centralized administration began to seek to rule the colony directly, and as the intensity of its projects increased, knowledge about local conditions accumulated at the centre of government." ${ }^{, 73}$ The census was the key tool in acquiring that knowledge. From Corrigan and Sayer, Curtis draws the idea that political power requires cultural leadership, "the fashioning of imaginaries of whence current conditions came." The census served to create the imaginary of a manageable Canadian population by connecting "people as state subjects and citizens to official identities within a determinate territory in order to rule them. It does so through the disciplining of social relations and the centralization of knowledge. ${ }^{.75}$

By drawing on Foucauldian notions of governmentality, Curtis introduces an emphasis on techniques, disciplines, and power/knowledge to the study of Canadian state formation. He writes that, "governmentality broadens our understanding of domination and rule...it points to the production of disciplined and self-disciplined individuals; yet it also draws attention to totalizations, potential bases of social solidarity, and objects of rule without limiting solidarities exclusively to relations of class." ${ }^{, 76}$ There has been much written on the expansion of liberalism in nineteenth-century Canadian history. ${ }^{77}$ Curtis's

\footnotetext{
${ }^{73}$ Bruce Curtis, The Politics of Population: State Formation, Statistics, and the Census of Canada, 18401874 (Toronto: University of Toronto Pres, 2001), 7. Curtis has also explored this relationship between knowledge-production, governmentality, and state formation in a series of articles. Bruce Curtis, "The Canada 'Blue Books' and the Administrative Capacity of the Canadian State, 1822-1867," Canadian Historical Review, 74:4 (1993), 535-565; Bruce Curtis, "On the Local Construction of Statistical Knowledge: Making Up the Census of the Canadas," Journal of Historical Sociology, 7:4 (1994), 416-434. ${ }^{74}$ Ibid., 37.

${ }^{75}$ Ibid., 36.

${ }^{76}$ Ibid., 41.

${ }^{77}$ Ian McKay's influential article "The Liberal Order Framework: A Prospectus for a Reconnaissance of Canadian History," Canadian Historical Review, 81:3 (2000): 617-645, argues from the mid-nineteenth century onwards Canada's history has been governed by liberal ideas, notably the belief in individualism, equality, and property. There has been much written in response to this suggestion. Many of these debates are elaborated Jean-François Constant and Michel Ducharme, eds., Liberalism and Hegemony: Debating
} 
intervention highlights that even if greater freedoms were granted by political authority, there was still "more intense regulation." ${ }^{, 78}$ A liberal rationality operates at the level of the individual as well as on physical space and social abstractions. ${ }^{79}$ The census, for example, ties individuals to physical space as it creates official knowledge of the population.

This dissertation is written less strictly from a governmentality perspective than Curtis's work. It does not address questions of security, territory, and population central to many studies of governmentalities. ${ }^{80} \mathrm{I}$ do, however, take up his call to "analyse the state system as an organized set of capacities that are themselves objects of contest and struggle. $" 81$ Politicians debating civil service reforms and job-seekers asking for patronage were both governed according to dominant rationalities. These conditions need to be explored. Doing so is impossible without taking up a series of questions and insights from the work of Michel Foucault. Foucault and other theorists of governmentality address the connection between the government of the self and the government of others, stressing that in the liberal rationalities of the nineteenth century self-government was a key. Foucault described the role of the individual in liberal rationalities, noting that a person who wishes to govern others must first govern himself, his goods and his household. Conversely, when a state is well run the individual will

the Canadian Liberal Revolution (Toronto: University of Toronto Press, 2009). Jean-Marie Fecteau was also critical of McKay's approach, arguing that he ignored the regulatory aspects of this liberal order. As the rights of certain bourgeois individuals became better defined, they also established an order that marginalized and excluded those who did not fit - the poor, sick, and criminal. Jean-Marie Fecteau, $L a$ Liberté du pauvre : crime et pauvreté au XIXe siècle québécois (Montreal: VLB éditeur, 2004), 18.

${ }_{79}^{78}$ Curtis, Politics of Population, 40.

${ }^{79}$ In an American context Matthew G. Hannah, Governmentality and the Mastery of Territory in Nineteenth-Century America (Cambridge University Press, 2000) explores how mapping the American West was a crucial step in the creation of official knowledge and the mastery of territory.

${ }^{80}$ Michel Foucault, Security, Territory, Population: Lectures at the Collège de France, 1977-1978, Michel Senellart, ed., Translated by Graham Burchell (New York: Palgrave Macmillan, 2004). These issues are also central Mitchell Dean, Governmentality: Power and Rule in Modern Society (London, Sage Publications, 1999) and Nikolas Rose, Powers of Freedom: Reframing Political Thought (Cambridge: Cambridge University Press, 1999).

${ }^{81}$ Curtis, Politics of Population, 43. 
know how to manage his family and his affairs. ${ }^{82}$ The role of governing and disciplinary institutions is to therefore join "together the state's strength and individual felicity. This felicity, as the individual's better than just living, must in some way be drawn on and constituted into state utility: making men's happiness the state's utility, making men's happiness the very strength of the state. ${ }^{, 83}$ These processes are linked to processes of state formation. As state forms were elaborated, individuals were more clearly connected to territories and practices - they could better recognize how to govern themselves. Since these forms evolve over time, they need to be understood historically. The nineteenth century was a period of profound change, which, according to Foucault, "gave rise to a certain way of thinking, reasoning, and calculating. ${ }^{" 84}$ This liberal governmentality and rationality followed political economic ideals, and was enacted on individuals. Foucault's provocations are especially important in Part Two of this dissertation which connects the public debates about civil service reform to personal letters seeking patronage. As will be shown, job-seekers needed to demonstrate their self-government, and at times linked this to their household and community participation. In doing so they drew on the official rhetoric and conceptions, even as they attempted to circumvent official practices.

This dissertation treats both the debates over patronage and the letters requesting patronage as understandings of state formation and conceptions of government. The choices made with respect to the reading of evidence and the organization of the chapters, stem from the conceit that the processes through which the state was constructed need to

\footnotetext{
${ }^{82}$ Foucault, "Governmentality," 91-92.

${ }^{83}$ Michel Foucault, Security, Territory and Population: Lectures at the Collège de France, 1977-78, edited by Michel Senellart, translated by Graham Burchell (New York: Palgrave Macmillan, 2007), 327.

${ }^{84}$ Ibid., 286.
} 
be understood from below as well as from above. ${ }^{85}$ Elites participated in the debates on how public jobs should be managed, while potential workers attempted to fit themselves within this frame. Both groups engaged in what anthropologists Thomas Blom Hansen and Finn Stepputat call the "language of stateness." ${ }^{.86}$ To understand this language, they suggest that

one study how the state tries to make itself real tangible through symbols, texts, and iconography, but also that one move beyond the state's own prose, categories, and perspective and study how the state appears in everyday and localized forms: in brief, to study the state, or discourses of the state, from 'the field' in the sense of localized ethnographic sites, whether 'inside' or 'outside' of the evanescent boundaries between society and the state that usually crumbles when subjected to empirical scrutiny. ${ }^{87}$

Studies of state formation should aim to understand how the governors and the governed imagine the state. By exploring both "inside and outside of the evanescent boundaries between society and state," Hansen and Stepputat offer avenues to overcome reductive dichotomies of state and civil society, governors and governed. They suggest that the abstract "language of stateness" is reproduced and altered in everyday, localized contexts. Similarly, Timothy Mitchell highlights these unclear boundaries as an effect - that is a process and a construct - resulting from the expansion and development of governmental techniques. He writes, "we must analyze the state as such a structural effect. That is to

\footnotetext{
${ }^{85}$ Gilbert M. Joseph and Daniel Nugent make this suggestion in their introduction to Everyday Forms of State Formation: Revolution and the Negotiation of Rule in Modern Mexico. They claim the collection seeks to "fashion an analytical framework for simultaneously integrating views of the Mexican revolution 'from below' with a more compelling and nuanced "view from above." "Popular Culture and State Formation in Revolutionary Mexico" in Gilbert M. Joseph and Daniel Nugent, eds., Everyday Forms of State Formation: Revolution and the Negotiation of Rule in Modern Mexico (Durham: Duke University Press, 1994), 12.

${ }^{86}$ Thomas Blom Hansen and Finn Stepputat, "Introduction: States of Imagination" in Thomas Blom Hanson and Finn Stepputat, eds., States of Imagination: Ethnographic Explorations of the Postcolonial State (Durham: Duke University Press, 2001), 5.

${ }^{87}$ Ibid., 5. Sayer makes a similar point: "state forms or enactments do not merely constrain. The may also empower and enable, often in differential ways (men against women, for example). Individuals and groups may creatively adapt and use the forms through which, on another level, they are confined and constrained." Derek Sayer, "Everyday Forms of State Formation: Some Dissident Remarks on 'Hegemony'," in Nugent and Joseph, eds., Everyday Forms of State Formation, 376.
} 
say, we should examine it not as an actual structure, but as the powerful, apparently metaphysical effect of practices that make such structures appear to exist." ${ }^{\text {"88 }}$ Viewing state formation as an effect of cultural practices such as letter writing invites novel and critical approaches to understanding the history of political and social relations. For instance, those who are marginalized from political power may still influence state formation through their resistance, or through techniques used to bring them into the totalizing image of the state. Rather than accepting the dichotomies between patronage and democracy, or between politics and administration, I propose that Canadian patronage can be understood through this perspective. As patrons struggled to balance their power with a professionalizing civil service, and clients struggled to find work within the changing context, both articulated ideas about public work and public service. These had material consequences - they oversaw the expansion of state offices and actual employment of the clients. Rhetorically these interactions also challenged, restated, and confirmed the construction of a public servant.

\section{Outline}

This dissertation is divided into two sections. The first focuses on the debates, ideas, and rhetoric of politicians and administrators as they attempted reconcile patronage with the growing demand for an independent and professional civil service. It is bookended by chapters on the debates and findings of the Royal Commissions on the Civil Service in the early 1880 s and 1890 s. The middle chapter is a case-study of a pamphlet published by William Kingsford, an engineer in the Department of Public Works, after he was dismissed following the election of 1878 . Reading parliamentary debates,

\footnotetext{
${ }^{88}$ Timothy Mitchell, "Society, Economy and the State Effect," in Steinmetz, State/Culture, 89-90. Mitchell's emphasis on practices and techniques of government draws heavily from a Foucauldian Governmentality approach.
} 
newspapers (primarily The Globe), pamphlets and official documents on the civil service, and the Civil Service Commissioners' Reports, these chapters explore how ideas of partisanship, professionalism, efficiency and democracy were defined in the mid- to latenineteenth century. In Part Two, three chapters analyze different strategies used in letters requesting appointments. They focus on how job-seekers ask for help and strengthen their claims. These approaches vary from references to community authority, references to the applicants' bodies, and in the last chapter, to emotional appeals. An ironic thread runs through these three chapters, as applicants needed to ask for help while demonstrating the independence required for public work. These letters are efforts to make a claim for public authority and power through the author's private life. The letters are attempts to demonstrate self-governance, while asking for a chance to govern others as part of the bureaucracy. Patrick Joyce's use of governmentality for social history is illuminative here. For nineteenth-century Britain he describes a system of government based on cultivating the self while simultaneously watching (surveilling) others. This leads to what Joyce labels a "performative liberalism." ${ }^{" 89}$ This notion of performance is interesting for patronage letters. To my eyes they were performative acts, as they make private lives public and increase publicity for the applicant's public life.

Both sections of this dissertation are largely studies of federal Conservative politics in the Victorian Era. The Conservative Party was in power for the entirety of the period covered, except for 1873-78. Jeffrey Simpson suggests that, in this period at least, Conservatives were more effective in using patronage. This was not the case going into the twentieth century, when, under Laurier, the Liberals gained power and used patronage

\footnotetext{
${ }^{89}$ Patrick Joyce, The Rule of Freedom: Liberalism and the Modern City (London: Verso, 2003), 106.
} 
to reward their supporters. ${ }^{90}$ Given this balance of power, the bulk of the letters asking for appointments I read were to John A. Macdonald, George-Étienne Cartier, Samuel Leonard Tilley and Charles Tupper since all occupied important positions of power and influence during these years of largely Tory rule. In these four archives there were thousands of such letters. Although it would be interesting to compare these letters to those written to other politicians, and to compare federal ones to provincial ones, that would be prohibitively time consuming for this project. The choice of these four politicians also allowed me to pursue key themes across regions, as I explore letters from New Brunswick, Nova Scotia, Quebec, and Ontario - the four provinces that entered Confederation in 1867. In the introduction to Part Two, I speak in more detail about the methodology with respect to how I read and analyze the letters.

In the introduction to Capitalism, State Formation and Marxist Theory, Corrigan, Sayer and Harvie Ramsay write that "the State is constructed and fought over." 91 This dissertation is about constructions of and fights over the civil service. Politicians, administrators, and job-seekers all expressed a range of opinions on how it should be managed, staffed and constructed. These fights took place in the corridors of power. They were partisan and ideological debates. Challenges also came from all over the country in people asking for jobs. In writing to politicians, applicants were demonstrating how they understood and expected the appointment process to work. These appeals also reflected

\footnotetext{
${ }^{90}$ Simpson, Spoils of Power, 101-102, 107; Whitaker makes a similar point, noting that "The Liberals were the pre-eminently successful political party at the national level from the mid-1930s on, and they based their success on a combination of traditional patron-clients relations at the local level with dependence upon the policy inputs of the senior service," "Between Patronage and Bureaucracy," 63. He explores this in more detail in The Government Party: Organizing and Financing the Liberal Party of Canada, 1930-58 (Toronto: University of Toronto Press, 1977).

${ }^{91}$ Corrigan, Harvie Ramsay, and Derek Sayer, "The State as a Relation of Production," in Philip Corrigan, ed. Capitalism, State Formation and Marxist Theory (London: Quartet Books, 1980), 17.
} 
what type of people should have access to the civil service, and what type of people the applicants thought they were.

There was a space between what civil service reforms tried to do and what they did. This space was what allowed patronage to continue and represented a site where partisanship could continue and where non-ideal civil servants could engage the state apparatus. This was a rhetorical space in that how to ask for a job and how to write to power were socially governed. It was also a material space, since people where asking for jobs and for money. These jobs, in turn, linked a federal state to the many local communities and individuals it administered. In Victorian Canada, the politics of patronage were everyday issues. As public policy advisors and civil service reformers attempted to separate party politics from administration, they introduced a range of political practices that affected the management, the practices, and the make-up of the civil service. These changes shifted how would-be civil servants presented themselves to local and party patrons. 


\section{Part One}

Debating, Constructing, and Regulating the Civil Service,

1867-1892 


\section{Chapter 2}

\section{'The greatest possible public as well as party service:' Patronage, Politics and Rhetorics of Reform, 1867-1882}

We believe... that public men, realizing how much the prosperity and welfare of the country depends on a pure and efficient Civil Service, will not hesitate to abandon a patronage which is found to be injurious to the best interests of the country and which generally admitted to be a source of weakens and annoyance to themselves, as well as demoralizing to the constituencies. ${ }^{92}$

Report of Civil Service Commission, 1881

In 1878, James Domville, Member of Parliament (hereafter MP) for the recently elected Tories, rose in the House of Commons to describe a Liberal rally in New Brunswick that had transpired in the election. At this meeting, he explained, "the chairman... gave out the watchword: 'to the victors belong the spoils,' and they all cheered and clapped their hands at the sentiment... The whole election was run on the question that "to the victors belong the spoils.",93 Even in the House, Domville's comments appeared as a stridently partisan accusation; since the mid-1870s politicians from both parties had begun to advocate for civil service reform in which questions of party loyalty were to be displaced by objective meritocracy and ability. Yet Domville's remarks allude to how nascent this process of change still was in 1878 . At the same time as calls for reform emerged, patronage remained entrenched in the culture of Canadian politics.

The movement for reform was largely a federal movement for the Canadian civil service. As such, this chapter starts with the reorganizations following Confederation in 1867. Although that does not represent the starting point for Canadian patronage or for

\footnotetext{
${ }^{92}$ Canada, Parliament, Sessional Papers of the Dominion of Canada, Volume $10,4^{\text {th }}$ Parliament, $3^{\text {rd }}$ Session, (Ottawa: Maclean Roger, 1881), 13.

${ }_{93}$ Canada, Parliament, Debates of the House of Commons, $4^{\text {th }}$ Parliament, $1^{\text {st }}$ Session, vol. 1 (Ottawa:

Citizen Print. and Pub. Co., 1879), 554.
} 
this research project, it is a useful starting point to study the federal reforms to the civil service that came later in the century. In the aftermath of Confederation, the Canadian state underwent a series of transformations. Political relationships were in flux as local institutions came into contact with new, expanding federal authorities. The civil service was one of the institutions where these interactions took place.

Traditionally, these positions were governed by patronage, with ministers appointing whomever they thought fit, but this process came under scrutiny as the federal state apparatus began to coalesce and expand in both the capital and in local offices. As I explore below, these powers were slightly curtailed by the Civil Service Act of 1868 but only modestly. This appointment process was not seriously debated until the federal election of 1878, when patronage and appointments based on personal connections began to be criticized by members from both the Conservative and Liberal parties. These shared concerns over patronage led to the formation of the Civil Service Commission in 18801881, whose recommendations were instituted with the 1882 Civil Service Reform Act. More than its 1868 predecessor, this later act introduced profound changes to the structure of the Canadian civil service. Still, the act did not eliminate patronage nor partisanship in the appointment process. Despite the shared rhetoric of "reform" there was neither the political nor the popular will to overhaul the appointment system. Politicians still sought to reward their allies, while applicants still made personal claims on available situations. Even as reforms were codified into regulation and practice, personal connections between politicians and their constituencies remained important avenues of political power and political access. 
These contradictory impulses were performed in a series of parliamentary speeches and newspaper articles on civil service reform. I treat these texts as rhetoric to explore what they reveal about the period's political culture and processes of state formation. Discussions of patronage were based in understandings of politics and administration that were undergoing significant transformations. These political, cultural and administrative changes drew from programs across the colonial world. I suggest that, somewhat surprisingly, these shifts were manifested in a series of statements that promoted civil service reform while also promoting partisan patronage. After exploring the international reform movements, this chapter shifts to the debates over patronage and partisanship in the federal election of 1878. The chapter then ends with a discussion of civil service commission of $1880-1881$ and the debates and criticisms that followed the Civil Service Act of 1882.

\section{The Canada Civil Service Act, 1868}

The Canada Civil Service Act of 1868 was one of a series of federal reorganizations. Its goals were modest, to act as "a valuable safeguard against evils that were geared and irregularities that experience had shewn [sic] would probably arise in the administration of the public service." 94 It set the boundaries of who could be hired to the many positions, but these were formalities that could be avoided. For instance the Act stipulated that only candidates that were between eighteen and twenty-five years old could be appointed. A person over twenty-five, however, could "be appointed to any office or clerkship upon the application and report of the Head of the Department, specifying the reasons therefore." The regulations were further curtailed by the

\footnotetext{
${ }^{94}$ Parliament, Sessional Papers, 1881, 11.
} 
stipulation that a person over forty could be appointed with "a report of the appointment and the reasons thereof... submitted to Parliament at its then next Session." 95

Age was not the only factor that weighed in the nomination process. The 1868 Act also stated that every candidate must "produce such evidence as the Governor may think sufficient to his age, health and moral character." ${ }^{" 96}$ This rule is significant for two purposes. The first is it suggests that the imagined civil servant had moral and physical characteristics, but no mention of qualifications. This is one of the aspects that came under fire in the movement for reform. Experience and skills become part of how an ideal civil servant was constructed. As we will see, however, the moral and physical characteristics remained part of this construction. These aspects were heavily gendered and classed. Ideals of independence, respectability, activity and masculinity were all integrated into the ideal civil servant. Even as intangible personal qualities became less important as qualifications, health and morality would still be considered.

Providing proof of age, health and morality codified the expectation of letters of support that all candidates needed to include in their applications. These testimonials were sent to the Civil Service Board to be evaluated, further entrenching letters of support in the appointment process. ${ }^{97}$ Central to finding letters of support were personal, and likely partisan, connections. As we will see, the connections fostered ideas of reciprocity between politicians and their supporters. These relationships proved difficult to replace as demands for civil service reform became more prominent.

\footnotetext{
${ }^{95}$ Canada, Parliament, Statutes of Canada, $1^{\text {st }}$ Parliament, $1^{\text {st }}$ Session, (Ottawa: Malcolm Cameron, 1868), 42 .

${ }^{96}$ Ibid., 43.

${ }^{97}$ Ibid., 48.
} 
One of the provisions of the Act that aimed to insure some standard of qualification was introducing a pass/fail entrance examination. These exams, however, were largely voluntary and administered informally by the deputy ministers of every department. ${ }^{98}$ These provisions were not regularly enforced. Bill Doherty, for example, notes that between 1875 and 1880 only one candidate was recorded as having taken the exam. ${ }^{99}$ Even in the wake of the 1868 Civil Service Act, political patronage thus continued to be the most effective way for a candidate to obtain a position in the state administration.

This ongoing expectation of patronage was stated in letters to Samuel Leonard Tilley, New Brunswick's leading supporter of Confederation (member of the Liberal Party, until 1867, then a Conservative). As the Minister of Customs, applicants hoped that Tilley would have "a larger amount of patronage than before," and that there would be new offices "untrammeled by the claims of any old servants to be moved forward a step." 100 Other letters expressed hope for the "likelihood of an increased working force being required" or the "necessity for two offices, or for at least two distinctive appointments in as much as one will belong to the general govt and the other to the local govt." ${ }^{\text {101 }}$ Patronage networks shifted with the processes of state formation. As the civil service was reorganized and the federal state was expanded, candidates anticipated new positions and possibilities.

\footnotetext{
${ }^{98}$ J.E. Hodgetts, The Canadian Public Service: A Physiology of Government (Toronto: University of Toronto Press, 1973), 265.

${ }^{99}$ Bill Doherty, Slaves of the Lamp: A History of the Federal Civil Service Organizations, 1865-1924 (Victoria, BC: Orca Books Publishers, 1991), 10.

${ }^{100}$ Library and Archives Canada (hereafter LAC), Sir Samuel Leonard Tilley Fonds, MG 27 ID 15, vol. 20 , WA Smith to Tilley, 7 August 1867.

${ }^{101}$ LAC, Tilley Fonds, vol. 20, James A. Whitney to Tilley, 6 June 1867; LAC, Tilley Fonds, vol.19, John H. Hughes to Tilley, 15 April 1867.
} 
The Civil Service Act of 1868 was a short and pragmatic statute that was drafted in a period of bureaucratic transformation and reorganization. A letter to George-Étienne Cartier, the Conservative party's Quebec chief, claimed it was so weak it was "sur le point de venir [sic] un farce." 102 The making of the Canadian state required standards to ease the amalgamation of the different provincial systems entering Confederation. The Act could not be more ambitious or specific since the bureaucratic needs were still unclear. As Canadian politicians and administrators became more comfortable with the mechanism of the new dominion, the demand for a more professional state apparatus became stronger. The election of 1878 brought these demands to public attention, yet it also underscored the tensions between reforming ideals and the desire to appeal to a public that expected reciprocity for its partisan loyalty.

\section{Colonial Contexts of Reform}

Canadian civil service reforms were part of experiments in bureaucracy that took place throughout the colonial world. Politicians drew inspiration and warning from international examples. For example, the validity of the 'spoils doctrine' was sometimes debated in reference to the American system. In the aftermath of the 1878 election, each party accused the other of abusing patronage. They frequently conceived their claims for reform in a patriotic and anti-American language. A New Brunswick paper, the Liberalbiased Daily Evening News, described these exchanges: "The Opposition [Liberals] has charged that the New Government has discharged a number of officials on purely political grounds, and thereby introduced the American rotation-in-civil-service plan, which the Canadian people hold in abomination."103 The government denied the charges,

\footnotetext{
${ }^{102}$ LAC, Sir George Etienne Cartier Fonds, MG 27 ID 4, H. Beaudry to Cartier, 16 April 1869, 217.

${ }^{103}$ Daily Evening News, "Civil Service Tenure," 21 March 1879, 2.
} 
and according to the paper, "in turn have accused the late Federal Administration of having repeatedly done the very thing which its friend impute to the existing Government." The result was that during the "discussion of these charges and counter charges, leading men on both sides of the House have stood on common ground relative to the true tenure of our Canadian civil service." 104 This "common ground," evidently, represented a rejection of American administrative practices. From the late-eighteenth century, what the Americans called "rotation" was an important principle in their politics and administration. Writing in the early twentieth century, Carl Russell Fish noted that, by limiting the number of years during which an individual could hold office, American politicians hoped to "educate as many of the people as possible in the business of political life, and to protect them from the usurpations of men habituated to office." ${ }^{, 105} \mathrm{~A}$ judicious use of partisan appointments, mid-nineteenth-century administrators and politicians suggested, could prevent factionalism and better link administrators to the "will of the people". ${ }^{106}$ It should be noted, that although Canadian politicians and reformers decried the American system, they did not engage in serious debates about it. Similarly, the Canadian reformers failed to note that American politicians had introduced a Civil Service Bill that attempted to institute a competitive entrance exam in $1865 .{ }^{107}$ Just as Frank Underhill noted regarding the Confederation debates of the early and mid 1860 s, the "American ogre" could serve rhetorically as an effective, unifying external

\footnotetext{
${ }^{104}$ Ibid.

${ }^{105}$ Carl Russel Fish, The Civil Service and the Patronage (New York: Russell and Russell Inc, 1904 (1963)), 83.

${ }^{106}$ Matthew G. Hannah, Governmentality and the Mastery of Territory in Nineteenth-Century America (Cambridge: Cambridge University Press, 2000), 52; Bernard S. Silberman, Cages of Reason: The Rise of the Rational State in France, Japan, the United States and Great Britain (Chicago: Chicago University Press, 1993), 234-242.

${ }^{107}$ Ari Hoogenboom, Outlawing the Spoils: A History of the Civil Service Reform Movement, 1865-1883 (Urbana: University of Illinois Press, 1961), 17.
} 
threat. ${ }^{108}$ The realities of the civil service were less important than the appeal to antiAmerican sentiment.

For these critics, the foil to the perceived corruption of the American system was the British civil service. In 1874, in a speech given to the Toronto Club, Lord Dufferin, the Governor General of Canada from 1872 to 1878 , expressed the hope that from England Canada would inherit a permanent and non-partisan civil service, which "disposed to make the service of the State rather than that of party their chief object."109 Dufferin's appeals found a receptive audience. Victorian Canadian state formation routinely adopted practices from other bureaucratic states, as in the cases of school inspection, prisons and poverty relief. ${ }^{110}$ Although elevated, the British system was not presented as flawless. Canadian reformers worried that permanent appointments made civil servants feel too secure and that age limits sometimes prevented qualified candidates from appointments. Still it appeared to some as a preferable option. In an 1881 article on civil service reform The Globe argued that "[a]ny reasonable man must admit that, in comparison with the defects in the American 'spoils' system, the imperfections of the British competitive system are practically non-existent."111

For both British and Canadian reform movements, "bureaucratic efficiency" was an important concern. In his study of the 1853 Northcote-Trevelyan report on British civil service reform, A.P. Donajgrodzki notes that, although regularly invoked, “efficiency" was ambiguously defined. Sometimes it referred to a department's ability to

\footnotetext{
${ }^{108}$ Frank H. Underhill, The Image of Confederation (Toronto: The Hunter Rose Company, 1964), 4.

${ }^{109}$ Lord Dufferin, Speeches and Addresses of the Right Honourable Frederick Temple Hamilton, Earl of Dufferin, edited by Henry Milton (London: William Cowes and Sons Ltd, 1882), 164.

${ }^{110}$ Bruce Curtis, True Government by Choice Men: Inspection, Education and State Formation in Canada West (Toronto: University of Toronto Press, 1992); Jean-Marie Fecteau, La liberté du pauvre: crime et pauvreté aux XIXe siècle québécois (Montreal: VLB éditeur, 2004).

${ }^{111}$ The Globe, "Civil Service Reform," 10 December 1881, 8.
} 
achieve its goals, while other times it referred to the new roles the authors envisioned for the civil servants. This circular logic adds to the term's opaqueness - increased efficiency was both the cause and the result of administrative reforms. Not surprisingly, Donajgrodzki concludes that "the report oscillates between one definition and another, and it is sometimes difficult to disentangle them."

Efficiency was also a keyword for Canadian reformers. The 1881 civil service commissioners were especially interested in the efficiency of the different departments. In their interviews with witnesses they asked qualitative and quantitative questions about the number of workers and the type of work performed. For example, to the Chairman of Inland Revenue they asked: "Do you find your staff an efficient one, or have you a larger number than are required for the performance of the work?" 113 In line with this, the commissioners also asked the Deputy Minister of Militia and Defense if they had "a larger number of officers in your Department...than are required for the work?” and could the work "be carried on with a smaller staff of more efficient assistance?"114 Although not defined, efficiency seemed to be connected to the size of staff and the amount of work performed. ${ }^{115}$

In both countries, the frequent invocation of "efficiency" suggests that reforming rhetoric drew from nineteenth-century political economy. This school promoted the use of social sciences and reason to govern conduct. ${ }^{116}$ The ambiguity of meaning, however,

\footnotetext{
${ }^{112}$ A.P. Donajgrodzki, "New Roles for Old: The Northcote-Trevelyan Report and the Clerks of the Home Office, 1822-48," in Sutherland, Studies in the Growth of nineteenth-century Government, 83-84.

${ }^{113}$ Parliament, Sessional Papers, 1881, 121.

${ }^{114}$ Ibid., 84.

${ }^{115}$ Here the commissioners are in line with the reformers Michael Piva studied, whom he suggests were motivated by financial concerns, not administrative or political ones. Michael J. Piva, "Debt, Salaries and Civil Service Reform in Pre- Confederation Canada," National History, 1 (1997): 127-138.

${ }^{116}$ Michel Foucault stated that political economy "discovers a certain naturalness specific to the practice of government itself." The Birth of Biopolitics: Lectures at the Collège de France, 1978-1979, Michel
} 
suggests that politicians were reticent to be tied to a particular platform. Even while remaining unclear, by championing "efficiency" politicians could distance themselves from the existing order, which was seen as increasingly untenable. By not specifying a definition they were accorded more flexibility to combine emerging ideas with existing traditions and expectations. ${ }^{117}$

More precisely, while introducing his motion for civil service reforms in 1879, George Elliott Casey, Liberal MP from Ontario and originally a journalist, noted that they were based on the system that was used in the Indian Service. Its successes there, he argued, led the system to be adopted by other departments in the British bureaucracy. Casey, who had been agitating for a competitive examination and promotion by merit since 1875, argued that this system was based on "the business principle. Men were not chosen for their political sympathies, but for their fitness for the position, ascertained as far as this could be done without actual experiment." ${ }^{118}$ Here Casey referred to an idealized conception of business. Historians Graham D. Taylor and Peter A. Baskerville suggest that managerial reforms in mid-nineteenth century Canadian businesses were

Senellart et al. eds. Translated by Graham Burchell (New York: Palgrave, 2008), 15. Similarly, Corrigan and Sayer note that political economy was "simultaneously the discovery of economy (and 'the economy' argued for as a self-sufficing private realm governed by the laws of the market) and a politicization of a moral code (entailing specific forms of 'policing') that makes that possible." Philip Corrigan and Derek Sayer, The Great Arch: English State Formation as Cultural Revolution (Oxford: Basil Blackwell, 1985), 105. Both these passages suggest that politics and economics, like nature, followed observable laws. Furthermore, these laws could be internalized by individual subjects and would act as disciplinary mechanisms.

${ }^{117}$ As Partha Chatterjee suggests in Nationalist Thought and the Colonial World: A Derivative Discourse (London: Zed Books, 1986), the political world is one "where notions are inexact, and have political value precisely because they are inexact, and hence capable of suggesting a range of possible interpretations" (vii).

${ }^{118}$ Canada, Parliament, Debates of the House of Commons, $4^{\text {th }}$ Parliament, $1^{\text {st }}$ Session, vol. 2 (Ottawa: Citizen Print. and Pub. Co., 1879), 1270. Casey had first proposed these reforms in 1875. Casey's career and support for reform were outlined in an 1895 profile in The Globe, "Mr. Casey, M.P.: A Parliamentary Patriarch at Forty-Five; A Civil Service Reformer; The Youngest Member Ever Elected,” 25 January 1895, 6. 
"akin to groping in the dark." ${ }^{119}$ Even into the 1870 s and 1880 s, as accounting practices made it easier to evaluate employees, Taylor and Baskerville argue that, at times, "[k]in triumphed over business efficiency." ${ }^{120}$ In Northern Enterprise, Michael Bliss makes a similar point regarding life insurance companies. Emerging in the mid-nineteenth century, these companies, he suggests, were vulnerable "to practically every form of mismanagement," including bad investments, misjudgment, and "simple theft from poorly chosen agents." ${ }^{121}$ Hiring practices among Canadian businesses were neither as reformed nor as effective as Casey suggested. Despite the rhetoric not matching the realities of business practices, civil service reformers elevated private enterprise as a realm where efficiency was more important that personalities. Rather than personal and partisan connections, among other things the proposed reforms would rely on an examination to measure and compare candidates. In the context of mid-nineteenthcentury British reform, mentioned above, Jennifer Hart notes that many of patronage's critics were professionals who wanted to instill their administrative views on public departments and to ask "what sort of people were in them and how they got appointed. Hence there was much talk in and out of parliament of a place-hunting aristocracy and of idlers and pleasure-seekers who were appointed to oblige the political adherents of the government." ${ }^{\prime 22}$ Such a system increasingly seemed outdated and out-of-place in the context of Victorian conceptions of political economy, where personal and party

\footnotetext{
${ }^{119}$ Graham D. Taylor and Peter A. Baskerville, A Concise History of Business in Canada (Toronto: Oxford University Press, 1994), 184.

${ }^{120}$ Ibid., 183.

${ }^{121}$ Michael Bliss, Northern Enterprise: Five Centuries of Canadian Business (Toronto: McClelland and Stewart, 1987), 274.

${ }_{122}$ Jennifer Hart, "The Genesis of the Northcote-Trevelyan Report," in Sutherland, Studies in the Growth of nineteenth-century Government, 69-70.
} 
connections were (or at least were said to be) replaced by a measured and thus a known and trusted competency.

Casey's belief in measuring qualification, "ascertained as far as this could be done without actual experiment," also sought to elevate the bureaucracy to be outside, or at least removed from the passions of electoral politics. ${ }^{123}$ His appeals to measured competencies were predicated on a logic in which politics, society and the economy could be managed through rational knowledge, observable laws, and predictive patterns. Mark Neocleous's study of nineteenth-century British civil service argues that bureaucratic administration actively shaped civil society, but that for this to occur the administrative state had to appear standardized and regulated. These standards established norms that governed and disciplined both the administrators and the population they oversaw. ${ }^{124}$ The entrance exam championed by Casey for the rapidly expanding Canadian federal civil service certainly fit this broader nineteenth-century movement towards regulation and technical, rather than personal, qualifications.

A technical and economic language was also applied to the applicants themselves. Casey suggested that there would be no problem filling the civil service with suitable candidates. "Considering the number of professional men, school teachers included,

\footnotetext{
${ }^{123}$ Parliament, Debates, 1879, vol. 2, 1270.

${ }^{124}$ Mark Neocleous, Administering Civil Society: Towards a Theory of State Power (London: Macmillan Press, 1996), 44. Drawing from Marx and from Foucault, Neocleous's broader argument is that administrations mediate between the separate spheres of state and civil society. Bruce Curtis explores this relationship between the politics of empirical knowledge and government. He describes the period from $1840-1874$ as "one in which statistics as a form of knowledge became increasingly removed from its origins in historical, geographical and literary description. Discursive elements were purged from the visible surfaces of statistical practice, and statistics came to be seen primarily as knowledge in numerical form." Bruce Curtis, The Politics of Population: State Formation, Statistics, and the Census of Canada, 1840-1874 (Toronto: University of Toronto Press, 2001) 5. This transformation of raw data into statistics was essential to centralizing administration, which relied upon knowledge of the local conditions it sought to govern. These themes are also important in Curtis's article "The Canada 'Blue Books' and the Administrative Capacity of the Canadian State, 1822-1867," Canadian Historical Review, 74:4 (1993), $535-565$.
} 
annually trained in their public schools," he claimed, "there would be an abundance of raw material. ${ }^{125}$ By viewing applicants as materials, Casey underscored an industrial view of civil servants. What constituted a "professional" in this period was also contested and changing construction. For nineteenth-century Ontario, Gidney and Millar suggest the term referred to liberal or learned professions, where specialized knowledge and training conferred authority. ${ }^{126}$ Though Casey did not specify what he meant by "professional men," this statement suggests the shift Casey and others were trying to effect from a personal and partisan government to one based on expertise and training. In the patronage system, personal connections and partisan actions were fundamental to securing an appointment. By treating the applicants as raw materials, however, Casey implied that they follow the laws of political economy where personal connections become less important than measurable ability and experience. In the professionalized system, applicants could be managed and compared more easily, according to defined and technical criteria. As "raw material," applicants could also be shaped and managed into civil servants. This is also indicative of a Victorian understanding of citizenship and improvement, whereby citizens could be trained and put to work for social and state goals. $^{127}$

\footnotetext{
${ }^{125}$ Parliament, Debates, 1879, vol. 2, 1272. The gendered implications of 'professional men' are worth noting. Women were not able to be civil servants until after the 1881 Civil Service Commission's reforms. Even after 1881 they were only allowed to hold the lowest positions.

${ }^{126}$ R.D. Gidney and W.P.J. Millar, Professional Gentlemen: The Professions in Nineteenth-Century Ontario (Toronto: University of Toronto Press, 1994), 5, 205-206.

${ }^{127}$ Schools were one such place of training and improvement. Xiaobei Chen, Tending the Gardens of Citizenship: Child Saving in Toronto, 1880s-1920s (Toronto: University of Toronto Press, 2005). Voluntary associations were also imagined as sites of improvement, where knowledge was shared and put to common, industrial, and, often, nationalist ends. As Darren Ferry reminds us, however, these were also sites of class negotiations where "The commercial possibilities of science and technology could also represent contested terrain relating to various interest groups." Darren Ferry, Uniting in Measures of Common Good: The Construction of Liberal Identities in Central Canada, 1830-1900 (Montreal and Kingston” McGill-Queen's University Press, 2008), 254.
} 
As Casey recognized, such a separation of party politics and administration had been tested and developed in the Indian civil service, where many would-be reformers of the Canadian civil service had spent time, including Lord Dufferin, who served as undersecretary of State in India in the 1860s. Issues of paternalism versus democracy, and public opinion versus expertise, were debated and evaluated by India's administrators earlier in nineteenth-century. By the 1830 s, under Charles Metcalfe, who would later serve as Governor General of Canada in the 1840s, personal rule based on paternalism and patronage was replaced with scientific administration based on data collection and permanent positions based on expertise. This shift was codified with a series of regulations passed in 1833 instituting a competitive entrance exam and standardized systems of supervising, recording, and surveying. ${ }^{128}$ This process of recording created knowledge of the governed people - a knowledge which one editorial called "the first thing, the second thing, and the third thing, in an Indian administrator."129 Drawing from John Stuart Mill's insistence that India was ruled by writing, Homi Bhabha stresses the importance of recording in colonial government. He writes: "events experienced and inscribed in India are to be read otherwise, transformed into the acts of government and the discourse of authority in another place, at another time." ${ }^{130}$ In the Canadian example the space of writing - the space between authority and experience - was less deferred. Canadian state formation - in post-Confederation Central and Atlantic Canada, at least is a less a story of colonial domination than the Indian case. Race is a central issue here.

\footnotetext{
${ }^{128}$ The classic study of this is Eric Stokes, The English Utilitarians in India (Oxford: Clarendon Press, 1959). This history is also surveyed in Anthony Kirk-Greene, On Crown Service: A History of HM Colonial Services and Overseas Civil Services, 1837-1997 (London: I.B. Taurus Publishers, 1999).

129 "The Indian Civil Service: It's Rise and Fall," in John Blackwood, ed., Blackwood's Edinburgh Magazine, (March 1861), 276.

${ }^{130}$ Homi K. Bhabha, The Location of Culture (New York and London: Routledge, 1994), 135. Italics in original.
} 
In the nineteenth-century imagination, the assumed whiteness of Canadian civil servants meant that they could directly engage with the governing apparatus. The distance between the federal centre and the rest of the country sometimes made it difficult for state authority to be implemented in Canada, but this is a different distance and authority than the racialized one identified by Bhabha.

Despite the perceived success of civil service reform in India and England, these transformations were not as total as their supporters often indicated. Reforms were passed and celebrated, but there was not a complete shift in administrative practices. Different territories and departments in India were administered differently, and paternalist practices continued. ${ }^{131}$ In England, the Education Department would continue to use patronage for the selection of its inspectors and examiners until $1914 .{ }^{132}$ Similarly, Lord Trevelyan continued to write letters requesting appointments for his family and allies even after the publication of his and Northcote's 1853 report. ${ }^{133}$ This was hardly unique. In Canada, as historian Michael Piva notes, modest bureaucratic reforms, including a Civil Service Entrance Exam, had been instituted in the United Canadas in $1857 .{ }^{134}$ And, as we have seen, the Canada Civil Service Act of 1868 also made some effort at establishing a voluntary entrance exam, administered by deputy ministers from every department. ${ }^{135}$ But, by the close of the 1870 s, this Act "was practically a dead letter" as patronage and partisanship had persisted unabated. George Casey based his own

\footnotetext{
${ }^{131}$ Dirk H.A. Kolff, "Administrative Tradition and the Dilemma of Colonial Rule: An Example of the Early 1830s," in C.A. Bayly and D.H.A. Kolff, ed., Two Colonial Empires: Comparative Essays on the History of India and Indonesia in the Nineteenth Century (Lancaster: Leiden University Press, 1986) 105.

${ }^{132}$ Gillian Sutherland, "Administrators in Education after 1870: Patronage, Professionalism, and Expertise," in Sutherland, Studies in the Growth of nineteenth-century Government, 263.

${ }^{133}$ Humphrey Trevelyan, The Indian We Left Behind (London: Macmillan London Limited, 1972), 58.

${ }^{134}$ Michael Piva, "Getting Hired: The Civil Service Act of 1857" Journal of the Canadian Historical Association, 3:1 (1992), 95-127.

${ }^{135}$ Hodgetts, The Canadian Public Service, 265.
} 
advocacy on the limits of the existing Act, arguing that it "provided only a means of excluding the totally ignorant and that even this means was not put in operation."

\section{Election and Administrative Turnover}

Immediately following the election of 1878 , civil service reform became particularly pressing in light of two connected, but seemingly contradictory concerns. The incoming Conservatives claimed that the outgoing Liberals would fill positions with their supporters and friends. At the same time the Liberals alleged that the Tories would soon clear the bureaucracy of known Liberals. In the debates that ensued both sides expressed support for a permanent and non-partisan civil service, made up of men with "more patriotism and less personal partyism, vigor and economy in the management of political affairs, and a well understood policy at all times." ${ }^{, 137}$ Both sides voiced their respective interest in reforming and professionalizing the Canadian bureaucracy, just as Casey stated, by following professional and business principles. The fact that both parties accused the other of using patronage, however, suggests that this rhetorical support for professionalization was coupled with attempts to maintain practical and political control of the appointment process.

Observing this political theatre from New Brunswick, the Daily Evening News reported that, "a slight ripple of excitement is passing over the face of the press relative to the question as to whether the outgoing Government is likely to fill the vacant offices at its disposal before surrendering the reins of power. The interest shown by the press in the matter is shared by the public." 138 That the public was interested in this debate suggests

\footnotetext{
${ }^{136}$ Parliament, Debates, 1879, vol. 2, 1267.

137 Daily Evening News, "The Party that is Popular with Progressionists," 29 August1878, 1.

${ }^{138}$ Daily Evening News, "The Appointment Question," 1 October 1878, 1.
} 
the social and cultural importance of government appointments. ${ }^{139}$ Here party loyalties seem to have been more important than belief in political or administrative principles. Liberal supporters encouraged the government to make last minute appointments, while the Conservatives suggested that after a defeat this was not a proper course. In doing so, both parties found themselves arguing against the very principles they had defended in 1873. These stances seem to be particular to the immediate circumstances, rather than general tradition. Seemingly aware of this situation, the Daily Evening News wrote that "the leaders of the opposing parties have propounded the opposite doctrines as to the right of an outgoing government to exercise the appointing power.” The leading Tories "asserted that a dying Administration has the right to exercise all its functions up to the last moment of its existence," a belief that they "acted upon its last hours in 1873." ${ }^{140}$ At the same time, the "Reform leaders have laid it down as a fundamental principle that an Administration that has manifestly lost the confidence of the people should not undertake to dispose of the patronage of the Crown." The newspaper suggested that should the Mackenzie administration "in its last moments, exercise the appointing power...its opponents on their own principles could not possibly condemn the act, and its friends could not, on their principles, consistently defend it." ${ }^{\text {141 }}$ These passages indicate the paradoxical position both sides came to adopt, each supporting ideas they had decried five years earlier. It also shows the enduring importance of job allocation in the period's political culture. Despite the partisan political disagreements, both sides suggested that

\footnotetext{
${ }^{139}$ Public interest in administrative matters is further commented on in the following chapter, which deals with William Kingsford's detailing of his dismissal by Hector Langevin.

${ }_{140}$ Daily Evening News, "The Appointment Question," 1 October 1878, 1.

${ }^{141}$ Ibid.
} 
bureaucratic staffing was a political question - a question of rights and principles, and to some degree a matter of serving the citizenry.

As the Liberal party came into government in 1873, Alexander Mackenzie had been highly critical of the Tories' use of patronage. He made himself Minister of Public Works, a portfolio that traditionally oversaw many patronage appointments, and attempted to apply his own standards to the department, ridding it of what he saw as corruption. As Jeffrey Simpson notes however, the position "burdened him with a thousand details, and made him the lightning rod for complaints from the Liberal's own mob of office-seekers, contractors and partisan hangers-on."142 Mackenzie's personal opinions on patronage were difficult to reconcile with the party's and the public's demand for appointments based on partisan and personal connections. As they were leaving power in 1878, Mackenzie's Liberals again navigated this tension between pragmatism and principle by making some last minute appointments, but not as many as their supporters would have liked. When these appointments were met with criticisms, the Daily Evening News dismissed them: the appointments "were so few when they might have been so many that it seems ridiculous for the Conservative critics to sling so much ink on this point. If the lately deceased Government did not act up to the very letter of the principles laid down by its leaders on this matter in their strictures on the course pursued by the Macdonald Government, it at least kept within easy reach of their spirit."143

Here the tension between keeping political control of the civil service and ensuring the professionalization of the civil service can again be seen. For party

\footnotetext{
${ }^{142}$ Jeffrey Simpson, Spoils of Power: The Politics of Patronage (Toronto: Harper Collins, 1988), 102. Simpson also notes: "as a wag put it, Macdonald could say no with more grace than Mackenzie could say yes" (104).

${ }^{143}$ Daily Evening News, "The Resignation and the Appointments," 15 October 1878, 1.
} 
supporters, it was enough that Mackenzie and his supporters kept within the spirit of their principles, if not to their principles themselves. While this perhaps underscores a cynical irony of political life, it also shows how deeply notions of reward and party loyalty ran in Victorian society. The article concluded by noting that, "Mr. Mackenzie deserves much credit for resisting the tremendous pressure brought to bear upon him by claimants for the office. The Montreal Herald says he did this at the heavy cost of displeasing his faithful friends." ${ }^{144}$ Despite the rhetoric of professionalization, many people, presumably with varying experiences and party claims, still sought patronage appointments. Letters continued to be written to politicians explaining the applicants' circumstances, and asking for positions within the federal bureaucracy. This seems to indicate that established expectations could not be easily managed much less erased by a federal government committed to reform.

Concerns over the treatment of civil servants after the election were also expressed in debates about whether the new Conservative government would dismiss employees who had been supporters of the Liberals. This concern was merited. Upon their return to power, there was pressure on the Conservatives to dismiss Mackenzie's appointments and to reinstate Tory supporters that had been dismissed by the Mackenzie government. This was expressed as political idealism rather than partisanship. A petition from the House of Commons was sent to Macdonald in 1879; it alleged that by dismissing Tory supporters "the Constitution of Canada, as derived from the Mother Country, has been violated and set at defiances [sic], and the "American System" simply

\footnotetext{
${ }^{144}$ Ibid.
} 
and undisguised has been substituted instead." ${ }^{\text {"145 }}$ This is interesting since it was not patronage that was being criticized, exactly, but the idea of rotation - the "American system.” The Conservatives did not suggest a better way to appoint people, but simply that once appointed they should not be dismissed for party reasons.

The potential for dismissal was generally manifested in two ways. The first was the fear that the Conservatives would dismiss anyone who had expressed sympathies or allegiances towards the now-opposition Liberals. As the next chapter will discuss, this was the case for William Kingsford, an engineer who served under both governments. The second fear was that new Tory government would punish those who "made themselves conspicuous for their partisanship in behalf of the Mackenzie Government in the general election contest." ${ }^{\prime 146}$ While subtle, the difference in the two positions is important. Many people argued that it was acceptable for civil servants to have political preferences. What was less acceptable was that they use their position or neglect it to do party work during an election. This debate centered largely on the definition of partisanship. For example, the Daily Evening News suggested, "the number of Dominion officials who took an offensively prominent part in the late great political struggle is probably quite small. It is quite possible that very many of them cast their ballots on the Government [Liberal] side; but if they did, that fact did not in itself constitute them political partisans." ${ }^{\prime 47}$ It was argued that the government should not punish a civil servant for preferring the opposing party. If punitive dismissals were allowed, both parties argued, it would introduce American-style administration, based on "to the victors belong

\footnotetext{
${ }^{145}$ LAC, Sir John A. Macdonald Fonds, MG26-A, vol. 307, House of Commons to Macdonald, 15 April $1879,140009-140010$

${ }^{146}$ Daily Evening News, "The Clamor for Dismissals," 29 November 1878, 1.

147 Ibid.
} 
the spoils" principles. While holding an office, however, civil servants were expected to be non-partisan and non-political. As the Daily Evening News argued, voting did not constitute offensive partisanship.

The degree of political participation allowed for civil servants was a contested topic in this period. There were debates about the relative merits of disenfranchising public servants. For some, civil servants should be allowed to vote, so long as they did so "in a quiet, inoffensive manner, according to their own convictions of duty." "148 In the House, Frédéric Houde, a Nationalist Conservative, argued for access to the vote by the civil service appointments in the language of citizenship. He stated that "a person was no less a citizen enjoying civil equality, though he should not belong to the party of the Government of the day." ${ }^{149}$ While all citizens, regardless of political allegiance, should be eligible for public service, Houde insisted, "public employés were required who were neutral in politics." ${ }^{\prime 50}$ In this view, a non-partisan civil service would be more democratic, as it would remove the pressures of political allegiance in the appointment process.

Others took a more severe stance. Dalton McCarthy, a Liberal-Conservative MP from Ontario, suggested, "it was a scandal, to say the least of it, that men in the payment of the country, who lived on the public money, and who were as much the servants of one as of the other party, should be permitted to interfere in elections on either side. ${ }^{151}$ In addition to calling for a non-partisan civil service, the reference to "living on the public money" seems to suggest the continuance of a slightly condescending attitude towards

\footnotetext{
${ }^{148}$ Daily Evening News, “Civil Service Interference in Dominion Politics”, 2 May 1878, 1.

${ }^{149}$ Parliament, Debates, 1879, vol. 1, 579-580.

${ }^{150}$ Ibid.

${ }^{151}$ Canada, Parliament, Debates of the House of Commons, $3^{\text {rd }}$ Parliament, $5^{\text {th }}$ Session, (Ottawa: Maclean, Roger, 1878), 2244.
} 
civil servants. As Michael Piva notes for the late 1850s and early 1860s, salaried employment was understood to be, in part, a form of dependence, and therefore not in accordance with masculine expectations of independence. ${ }^{152}$ Again, this indicates a tension between cultural values, in this case the economic independence and class status required for political citizenship, and the non-partisanship of professionals. In this view, public servants lost their political rights because they gave up their independence.

It was during these debates that Tory MP, James Domville, raised the issue of the Liberal electoral platform in New Brunswick, referenced at the start of this chapter. Domville claimed to be surprised that people would suggest the Conservatives supported partisanship in the civil service, since at the Liberal rally he attended the chairman promised patronage, and the audience applauded. ${ }^{153}$ Whether or not the accusation was accurate is less significant than how it was framed. Relying on patronage to garner popular support in local meetings was still a useful strategy. Domville's language also reflected the growing separation between trained experts and the public. He noted that the meeting's audience cheered at "the sentiment" of widespread patronage. This example highlights both the federal interest in reform and the continuing popularity of patronage. Whether referring to traditions of patronage and political influence or expressing calls for reform, commentators were making their arguments in reference to the particular circumstances and expectations in which they acted. ${ }^{154}$ Opposing parties and politicians often shared opinions over the preferred bureaucratic system, but they also shared an interest in maintaining partisan control. The promotion of neutrality created new

\footnotetext{
152 Piva, "Getting Hired," 107.

${ }^{153}$ Parliament, Debates, 1879, vol. 1, 554.

${ }^{154}$ As we will see later, Domville's quote also points to the role of local circumstances in shaping, shifting and complicating federal programs.
} 
problems for the politicians to address, regarding the role and nature of the civil service. If stances taken by politicians seemed to change between those in power and those in opposition, both sides, however, constantly referred to the creation of a better and less partisan civil service.

\section{Rhetorical Contradictions in Federal Debates}

The federal parliamentary debates over the management of civil servants following the 1878 election reveal a shared rhetoric of non-partisanship and permanency. Members from both parties seemed to agree that politics should be separated from the bureaucracy. When discussing Casey's proposed civil service reforms members from both parties expressed their support. Although there seemed to be a shared understanding by members from both parties that a professional and permanent public service was the preferred system, a variety of understandings were expressed. As we have seen, patronage and political appointments remained important even as members increasingly spoke of civil service reform. Some members of parliament were more open in their attempts to reconcile existing partisan appointment practices with the new context of professionalization.

Still, some MPs showed their attachment to older systems quite strongly. Frederick de Sainte-Croix Brecken, a Conservative from Prince Edward Island (PEI), explained that although he agreed that the Conservative government had not introduced the American system, he wished that it had. This thinking was based in the circumstances in his riding: As recorded in the Debates, "He [Brecken] had been endeavouring to have certain political opponents dismissed from office, but had not as yet succeeded. He did 
not, however, despair, but intended to try again." 155 Brecken went on to explain that dismissals after elections were particularly common in his province, consequently “among their most bitter and abusive opponents were men who held Dominion offices." 156 The administrative history in PEI, it seems, was one where civil servants were rotated when the government changed. Issues of loyalty and reciprocity were more important, in this case, than nonpartisanship or disinterested professionalism. Brecken claimed that he could not work with the previous government's administrators since they had no relationship, and the administrators had no reason to follow his platform. He wished he could dismiss these men, but the increasing emphasis on a permanent civil service made this difficult.

Although Brecken claimed he wanted to dismiss his opponents in PEI's civil service, his partisanship was also tempered by his support for reform. He admitted that he was generally in favour of a permanent civil service. He connected this to time-saving and public service. He explained that "he had to attend to a very large correspondence from his constituents on this very subject. He also admitted that it was more conducive to the public interest that the civil service should be permanent than that the staff of public servants should be dismissed upon every change of Administration." ${ }^{157}$ The reference to large correspondence indicates the popular expectation for rewards and the demand for patronage appointments. Brecken's stance also underscores a tension in the period's political culture. The non-partisan rhetoric of an efficient and permanent civil service was coupled with the attempts to conserve partisanship and political control. This also suggests that there was an important local dimension to Victorian political culture. What

${ }^{155}$ Parliament, Debates, 1879, vol. 1, 553.

156 Ibid., 554.

${ }^{157}$ Ibid., 553. 
was advantageous to proclaim in the House may not have matched with what was necessary to secure local support.

A letter from Isaac Buchanan, a merchant and former Member of Legislative Assembly for Hamilton, suggested that these contradictory feelings were pragmatic. Previously, he noted, he had supported civil service reforms, but "since it has been violated, I would think it worse than childish to commence insisting on a rule being in abeyance to exclude a man who has done so much for the public." ${ }^{158}$ Since the appointment process was still governed by partisanship, Buchanan suggested it was not the time to uphold ideals. This private letter suggests that politicians were grappling with the changing demands and circumstances. Although they recognized the importance of reform, they did not follow these tendencies at the expense of party power. This pragmatism, however, linked party and public good. Buchanan further suggested that a partisan appointment was justified, since the appointee had served the public, "if supporting you [Macdonald] (at great sacrifice to himself) has been, as we suppose the greatest possible public as well as party service." 159 As reform rhetoric gained momentum, these contradictions became common in discussions about the civil service. Advocates of civil service reform stressed permanency and non-partisanship. As we have seen, there were disagreements over how non-partisan and political interference would be defined; there were also some reservations expressed by members desiring to maintain political control of the government offices, and those desiring to keep an avenue to reward their allies. Despite these misgivings, there was a general agreement from both parties that "the discussion had revealed a deplorable state of affairs" and that this

\footnotetext{
${ }^{158}$ LAC, Macdonald Fonds, vol. 310, Isaac Buchanan to Macdonald, 29 November 1879, 140801.

159 Ibid.
} 
question was "distinct from all party feeling." 160 The debate led to a consensus that reforms were needed in the Canadian civil service. Within the context of professionalization the traditional reliance on patronage was no longer acceptable. Ideally, it was also argued, these reforms would benefit all politicians, freeing them from the demands for patronage appointments, and thus enabling them to focus on policy issues. To his colleagues in Parliament, Frédéric Houde asked, "could a Minister be completely free to act for the best, when he was solicited and importuned by dozens of members to grant such or such an employment to their protégés?"161 In the late 1870s, it seems that politicians were connecting civil service reform to concerns over the quality and nature of Canadian politics. Attending to questions of patronage took up their time and limited their ability to legislate effectively and fairly. Here, and in Houde's statement, we see evidence of attempts by politicians to separate politics and administration. Previously patronage had openly been an important part of Canadian politics. In the emerging context, however, this was no longer the case. If professionalizing was partially based on non-partisanship then making appointments could no longer be championed as a political responsibility or right. This is not to suggest that patronage stopped being important it Canadian politics, but rather that as reforming rhetoric took hold, the patronage process became increasingly monitored and regulated.

The quality of Canadian politics was further raised in reference to the type of people entering the civil service. Houde claimed that, as long as members of government made public appointments, there would be "too great a number of employés [sic], and much incompetence; the service now badly performed, and a useless increase in

\footnotetext{
${ }^{160}$ Ibid., 578.

${ }^{161}$ Ibid., 579.
} 
expenditure" ensued. ${ }^{162}$ An editorial in The Globe similarly highlighted the dangers of relying on patronage. It noted that the current system "causes self-seeking men of a low order of mind to degrade political contests; it is responsible for the appointment and retention in the public service of inefficient men... and for the insolent bearing with which petty officials, who obtain their places by favour of Ministers, disgust the public." 163 In another editorial, the paper connected patronage to "a serious defect in the national character," and an "evil" that "arises...from coupling service to a political party with the idea of reward out of the patronage that party may have to bestow." ${ }^{164}$ Given that both politicians and the public both continued to seek patronage, The Globe's rhetoric here was somewhat overblown. It does suggest, however, that ideas about politics, the public, character, and the civil service were changing in this period. The civil service's politicization was connected to inefficiency and dependence. The proposed solution to this situation was having an impartial Civil Service Commission that oversaw competitive entrance exams, and examined applicants based on merit rather than party claims.

As noted earlier, in his 1879 motion to institute civil service reform, Casey compared the civil service to private businesses. He went on to lament the fact that private businesses received a better class of applicants than the government, even when the government offered better pay. He attributed this largely to the hiring process. Taking aim at the 1868 appointment system, Casey stated, "[i]f a private institution wished to select an employé, they did not ask some of their friends to recommend a young man and then take him on trust," instead they "wished to be satisfied that the young man was

\footnotetext{
${ }^{162}$ Parliament, Debates, 1879, vol. 1, 579.

${ }^{163}$ The Globe, "Civil Service Reform," 9 July 1881, 8.

${ }^{164}$ The Globe, "Office Seeking," 8 July 1881, 4.
} 
capable of discharging the duties which would be imposed upon him, and that he was honest and had the physical ability to withstand the strain of the work he had to do."165 For Casey, This was not how the government operated. Rather than appointing the applicant best suited to a position, like a business, the civil service rewarded party connections. Seen this way, the proposed reforms to the civil service were, in Corrigan and Sayer's terms, cultural revolutions. ${ }^{166}$ Indeed, changing the appointment processes necessitated changing how politicians and their supporters conceived of party loyalty and public service. In this period there also occurred a shift in how bureaucrats were represented. While there was still some sentiment that public servants were "dependent" on public funds, there was also a growing sense that they should be educated and qualified, and respected as professionals.

Developing a body of practices to standardize civil service appointments also shifted the responsibility for satisfactory performance. The proposed reforms on public employees would formalize demands, other than party loyalty. In the existing patronagebased system employees were held responsible to their patrons, the politician that appointed them. Evaluating this system, Casey stated: "there could be nothing more hollow than this sham of responsibility." ${ }^{\prime 167}$ Politicians were not asked to justify their appointments, and were able to pressure and influence the appointees who depended on their protection. Casey went on to specify that the political nature of these appointments was problematic. Regarding appointments, he suggested that if a politician was

\footnotetext{
${ }^{165}$ Ibid., 1267. Again, note the gendered language that reflects how the ideal civil servant was imagined.

${ }^{166}$ Corrigan and Sayer, The Great Arch. They argue that one of the processes of state formation is establishing the "ways in which we are collectively represented to ourselves, and in which 'permissible' parameters and forms of individual identity are defined and symbolized for us" (6). The changing conception of civil servants is one part of these processes of collective representation. Despite the term 'revolution' these changes can occur slowly over generations.

${ }^{167}$ Parliament, Debates, 1879, vol. 2, 1268.
} 
"responsible to anybody it must be to his constituents; but his constituents were not always especially well qualified to judge the fitness of an appointment." As long as appointments were political, Casey feared, politicians might "appoint the man who was the most popular, and not the man whom he knew to be most fitted for the position."168 The call for a Civil Service Commission paralleled a movement toward accountability and performance standards. This demonstrated a growing separation between public opinion and public service, party and country, politics and processes of state formation. The language of professionalization aimed at being non-partisan. The goals of making the civil service permanent and professional went along with attempts to eliminate a longstanding, and at times emotional, public connection between patronage and public service. The above quote also highlights the changing status of professionals in a democratic culture. The reforming platform stated that, because of their training and positions, certain civil servants had the authority to evaluate other candidates. In addition to being a process of regulation and standardization, the professionalization of the civil service was also a process that contributed to the reification of civil servants as “experts." 169

One of the advantages of a regulated process was that it would be easier to understand how civil servants should "render those services to the country for which he had received a salary." 170 Thomas Robertson, the Liberal MP from Hamilton, stated "when a gentleman was appointed to a public office, it was understood, generally, to be

\footnotetext{
168 Ibid.

${ }^{169}$ In The Rule of Freedom: Liberalism and the Modern City (London: Verso, 2003) Patrick Joyce notes that the civil service exam itself was a "technology of publicity" that "fabricated an ethical persona for the administrator of government." The act of recruitment and assignment based on an entrance exam constructed the civil servant as neutral and qualified, therefore creating the authority to govern (123).

${ }^{170}$ Parliament, Debates, 1879, vol.2, 1268.
} 
the reward for the service of himself or his friends, on behalf of the party that put him in the position. When he had obtained his reward, he thought he should be encouraged, and, in fact, compelled to remain for ever out of the political arena." ${ }^{171}$ In this statement, the reason for appointment was separated from the role of the civil servant. While Robertson thought receiving a position should be a political reward, once in office he wanted civil servants to be non-political. Both Robertson's and Caron's statements suggest the ways by which the coexistence of partisan feelings with the plans for professionalization was possible at the time.

The agreement over the merits of regulating the appointment process led to a new contested issue: "the great angel, or demon, of Examination."172 Administrators and politicians debated how to best identify and distinguish those who were qualified for the civil service. Some politicians expressed reservations about the effectiveness of a competitive exam alone. One of the concerns was that "superior proficiency in the class of subjects selected as the basis of examination is not proof of the possession of practical capacity." ${ }^{173}$ While suggesting that appointments should be based on qualifications, there seems to be an implied, if mild, support for patronage in this statement. Letters of support from influential officials would be able to vouch for an applicant's practical ability - an ability that may be difficult to predict or quantify.

There were also debates in this period about the ability to measure proficiency. Critics of testing suggested that performing well in an examination "does not always indicate superior proficiency." This was especially the case, since "an undisciplined mind may be crammed by special effort for a special appearance. For cramming is not training.

\footnotetext{
${ }^{171}$ Ibid., 556.

172 Blackwood, "The Indian Civil Service: It's Rise and Fall," 264.

${ }^{173}$ Daily Evening News, “The Canadian Civil Service and Competitive Examination,” 7 April 1877.
} 
Nor does mere cramming give the crammed mastery over subjects on which he is supposed to be specially posted." ${ }^{\text {174 }}$ While expressing a doubt about competitive exams, this still suggests that there was a need to find a method to identify the best applicant. The disapproving reference to the "undisciplined mind" is also interesting, since it suggests that there was a proper way for individuals to be trained. There were similar debates over the nature of examinations for the Indian and English civil services. Critics in England argued that students focused too much on the competitive and not enough on education, claiming that "nothing is learned that should be learned, everything is taught that should not be taught." ${ }^{175}$ While admitting that applicants often crammed for the exam, its supporters replied that "well, it's better even to be 'crammed' than to be empty, either in head or body." ${ }^{176}$ The types of education and knowledge that were best suited for the civil service were contested. While some promoted classical education, others preferred the more pragmatic ability to briefly learn and demonstrate necessary skills. In Britain there were also debates on whether a written exam could measure a candidates' moral worth. Queen Victoria herself expressed concern over this. William Gladstone, the Prime Minister, assured her that "experience at the universities and public schools of the country showed that the test of open examination was also an effectual test of character as the previous industry and self-denial, without which proficiency could not be acquired, were rarely separated from general habits of virtue."177 This shows a different concern than those of Canadian reformers, but still suggests that testing was a contested system of

\footnotetext{
${ }^{174}$ Ibid.

${ }^{175}$ E. Ray Lancaster, "Competitide [sic] Examination," The Universal Review, (Nov 1888), 375.

${ }^{176}$ Ibid., 381.

${ }^{177}$ Shriram Maheswari, The Evolution of Indian Administration (Lakshmi Narain Agarwal, 1970), 34. Again, the racialized component means that concerns in India were somewhat different than in Canada. The whiteness of Canadian and British applicants gave them a perceived moral and intellectual advantage.
} 
measurement. While there were debates and doubts about the proper way to instill and to measure this discipline, there was a growing belief that there must be standard techniques to do so. ${ }^{178}$

Debates over civil service reform indicate a shared interest between Liberals and Conservatives to separate party politics and administration. Both sides expressed support for decreasing the reliance on personal and partisan patronage. Even as they stated this support, however, members from both parties, to some degree, continued to rely on and support patronage. This interaction between newer and older political practices indicates that reform was not a linear progression from 'Old Corruption' to a new professionalism. ${ }^{179}$ Civil service reform indicated a changing political culture, one that was uneven, inconsistent, and, we shall see later, thoroughly embedded in place. Indeed, politicians had to navigate between a variety of shifting interests and contexts.

\section{The Civil Service Commission}

The shared rhetoric of reform and professionalization was made manifest in 18801881 by the formation of a Royal Commission on the Civil Service. The Tory government appointed the commissioners. The chairman was Donald McInnes, "a

\footnotetext{
${ }^{178}$ Theodore M. Porter's Trust in Numbers: The Pursuit of Objectivity in Science and Public Life (Princeton: Princeton University Press, 1995) notes that having standardized systems of measurement and evaluation were central in transforming "local skills into generally scientific knowledge," which in turn helped establish central, bureaucratic control (21). Evaluating applicants for the civil service was part of this process.

${ }^{179}$ Drawing from E.P. Thompson, Corrigan and Sayer outline 'Old Corruption' as an "unrationalized" state form that was ascendant in England after the Glorious Revolution of 1688. It was a form that relied on "patronage-clientage, place-men and fee-plunder features of state employment in the eighteenth century." They differed from previous scholars by arguing that 'Old Corruption' was conducive to capitalism, if in complex and contradictory ways." Corrigan and Sayer, The Great Arch, 88-89. Drawing from The Great Arch in a Canadian context, Allan Greer argues that "[t]hough hardly a model of efficiency and harmonious administration, this system known to radical critics as 'Old Corruption,' managed to preserve the rule of a small class throughout the eighteenth century and well into the Victorian era. It did so essentially by combining a rather ramshackle state apparatus with a diffuse but highly effective network of social economic subordination." Allan Greer, The Patriots and the People: The Rebellion of 1837 in Rural Lower Canada (Toronto: University of Toronto Press, 1993), 88-89.
} 
gentleman of large experience" from Ontario. Edmond J. Barbeau - a "Montreal gentleman specially qualified and independent" - was his assistant. ${ }^{180}$ The commission reviewed the various departments of the federal civil service, interviewed department heads and workers, and had at "their disposal a very full collections of reports on all the continental systems as well as the system which obtains in England." ${ }^{, 181}$ The report was later praised as "one of the most thorough and satisfactory reports, I think, ever presented in relation to the civil service of any country." 182

The commissioners' report to Parliament was 41 pages long, but nearly 550 pages with appendices. McInnes and Barbeau based their inquiries into "the organization of each [department], the system of keeping the books, accounts and statistics, of collecting the revenue, of the checks on and control over the expenditure of the appropriations voted by Parliament for the public works, and for the various services appertaining to each Department." ${ }^{, 183}$ The report also included the transcripts of interviews with Department heads and letters from civil servants. The interviews with civil servants were varied in form and content, but the subjects were categorized as: appointments to office; promotion; efficiency of organization; efficiency of staff; sufficiency of staff; salary; temporary service; technical duties; discipline; accounts; superannuation; and new theoretical organization. ${ }^{184}$ Again, efficiency in one of the key concerns. In addition to the management and appointment of the civil servants, the commissioners also reported on the quotidian practices of the different departments. They suggested that offices keep

\footnotetext{
${ }^{180}$ Canada, Parliament, Debates of the House of Commons, $4{ }^{\text {th }}$ Parliament, $3^{\text {rd }}$ session (Ottawa: MacLean, Roger, 1881), 1396; Parliament, Sessional Papers, 1881, 9.

${ }^{181}$ Parliament, Debates, 1881, 1397.

${ }^{182}$ Canada, Parliament, Debates of the House of Commons, $6^{\text {th }}$ Parliament, $2^{\text {nd }}$ Session, (Ottawa: MacLean, Roger, 1888) 131.

${ }_{183}$ Parliament, Sessional Papers, 1881, 47.

${ }^{184}$ Ibid., 15.
} 
attendance books, so that the employees' arrivals could be documented and monitored. ${ }^{185}$ How the offices were organized and how the employees were situated/supervised was an issue of concern. The commissioners pointed to the Savings Branch of the Post Office as a good example of organization because "the offices are large enough to allow the clerks to come under the eye of their immediate superior. The result of this arrangement is to promote the efficiency as well as the economy of the service." ${ }^{186}$ According to this view, the possibility for constant supervision would improve the civil servants' work habits.

The specificity and scope of the report further suggests the importance of record keeping and documentation in administrative practices. The report similarly highlighted this, suggesting that every appointment and promotion should be published in the Canada Gazette, the official government newspaper. ${ }^{187}$ Publishing the appointments made them public and legible. This added an element of transparency and permanency to the appointment process. The power of writing was further made evident by an ironic silence. The commissioners noted that "in the course of our enquiry we have not allowed the name of a single individual to be taken down as being obnoxious to censure. We have thus endeavored to make our enquiry as little invidious as possible." They explained that this was not because there were no incompetent employees, but rather because it would not be fair to dismiss people who "have been brought into a Service for which they have little aptitude, by a faulty system for which they are not responsible, and under which there is an implied contract between the Government and its employees." ${ }^{188}$ Even as they attempted to minimize their influence, the commissioners respected the reciprocal

\footnotetext{
185 Ibid., 32.

186 Ibid., 49.

${ }^{187}$ Ibid., 24.

188 Ibid., 45.
} 
relationships between politicians and civil servants, or, patrons and clients. By blaming the system for incompetence, the commissioners could avoid attaching a permanent, negative mark to unfit employees.

The content of the commissioners' report, as with its recommendations, existed in an international context. The commissioners provided summaries of the systems used in the United Kingdom, France, Sweden, the German Empire, Belgium, and the United States. Furthermore, it included copies of the United States Civil Service Regulations, the Pendleton Act, and the Northcote-Trevelyan Report. These comparisons were used to show the successes of replacing patronage appointments with competitive examinations. Politicians understood the civil service as representing and reflecting Canada's place in the world. For Canadian politicians in the 1880 s, this usually meant measuring against and following the British example. When introducing the commissioners' report, Casey explained that "Neither they nor I can, of course, claim originality for these views, because they are taken almost without alteration from the system at present in operation in England." He went on to stress the empirical basis for these reforms: "the fact that it is not an untried or theoretical system is the strongest argument for the proposed scheme. The Commissioners conclude that a system which has been found to work almost perfectly in England, in curing the evils attached to political patronage, would have the same effect in Canada." 189 Here Casey reiterated the rising importance of political economy in reforming rhetoric. The proposed changes had been tested, and found successful - they fit with material and scientific understandings of progress.

The suggestions in the commission's report were codified in the 1882 Civil Service Act. This act implemented a series of changes reorganizing the civil service. One

${ }^{189}$ Parliament, Debates, 1881, 1396. 
of the crucial changes was the divisions of the service into the 'inside service,' which was the positions based in Ottawa, and the 'outside service,' made up of the offices in the rest of Canada. The act made a clear hierarchy of supervision, with department heads reporting to deputy ministers. These positions were still controlled and appointed by ministers. ${ }^{190}$ Despite not being raised during the discussion of the Bill, one of the more radical changes was that women were now allowed to enter the Civil Service, although only at the lowest level of clerk. Writing that "we see no reason whatever why female clerks should not be quite as efficient public servants as men," the commissioners still warned that there would still be "several obstacles in the way of their employment which we fear it will be very difficult if not impossible to overcome." ${ }^{191}$ Such obstacles were they would need separate rooms in which to work and other women should not supervise them. Even as the civil service was officially opened to women, this suggests that the ideal civil servant was constructed as male. Women were still not expected to enter the service. That this issue was not mentioned in the House of Commons further suggests that was not considered a serious option. Limiting women to the third class also shows the distinction between male and female civil servants. Young men entering the service were expected to progress to higher positions and higher pay. Women, on the other hand, were restricted to drudge work. More than limiting the material opportunities for female workers, this shows the ideal civil servant was imagined to be male.

Opening the civil service to women, while limiting their opportunities within it fit with the broader paternalism that working women faced in the Victorian era. Regarding female banking clerks in the early twentieth century, Kate Boyer notes these positions

\footnotetext{
${ }^{190}$ Hodgetts, 209-210.

${ }^{191}$ Parliament, Sessional Papers, 1881, 29.
} 
were often filled by educated, middle-class women who were paid roughly the same as male brick layers. ${ }^{192}$ In Limited Livelihoods, Sonya O. Rose describes a similar system in nineteenth-century British factories. Both employers and working men, she argues, “assumed a connection between 'career ladders,' technical competence and masculinity." 193 As in Canada's civil service, men were expected to advance to higher paying jobs, while women were restricted to dead-end positions. The civil service commissioners aimed at instituting business practices into the public service; limiting women to low-paying positions was one of these practices. ${ }^{194}$

The ideal civil servant was further specified in the 1882 Civil Service Act. Like the 1868 Act, candidates still had to be of appropriate age, health and moral character. A fourth characteristic was added to the description; applicants had to demonstrate the possession of "the requisite knowledge and ability to enter on discharge of his official duties." ${ }^{195}$ Here the term 'his' again stresses the civil servant's presumed gender. The general abilities required were as handwriting, orthography, arithmetic, and copying. For

\footnotetext{
${ }^{192}$ Kate Boyer, "Miss Remington" Goes to Work: Gender, Space, and Technology at the Dawn of the Information Age," The Professional Geographer, 56, 2 (2004), 203.

${ }^{193}$ Sonya O. Rose, Limited Livelihoods: Gender and Class in Nineteenth-Century England (Berkeley: University of California Press, 1992), 27. For retail work, Donica Belisle shows that department stores mostly employed and catered to women. Despite this, few women advanced to managerial roles, and even when they did it was in select departments typed as feminine. Even as department stores created spaces for women to work, they were still governed by assumptions on female servitude and inferiority. Donica Belisle, Retail Nation: Department Stores and the Making of Modern Canada (Vancouver: UBC Press, 2011), 163, 192.

${ }^{194}$ That the federal bureaucracy reproduced patriarchal arrangements and practices from industry and business fits with Rachel Harrison and Frank Mort's broader discussion of the connection between patriarchy and nineteenth-century state formation. They write that "the State can be seen to draw on, transform and modify particular sets of patriarchal relations, through legislation governing the transmission of property, marriage and sexuality, but it cannot be seen to create those relations. "Patriarchal Aspects of Nineteenth-Century State Formation: Property Relations, Marriage and Divorce, and Sexuality," in Philip Corrigan, ed. Capitalism, State Formation and Marxist Theory (London: Quartet Books, 1980), 81. This also follows insights about state formation and the entrenching of gender divisions, made by Lykke de la Cour, Cecilia Morgan and Mariana Valverde, "Gender Regulation and State Formation in $19^{\text {th }}$ C Canada," in Allan Greer and Ian Radforth, eds., Colonial Leviathan: State Formation in Mid-Nineteenth-Century Canada (Toronto: University of Toronto Press), 1992.

${ }^{195}$ Parliament, Sessional Papers, 188, 18.
} 
certain positions the commissioners suggested that geography, history (English, Canadian, and American), and book-keeping would be beneficial. These are the skills are generally those taught in a basic, high school education. They further noted that to work in Quebec "it has become evident... in order to act efficiently... a public officer should have such knowledge of French as will enable him to converse in that language." "196 Specifying ability and knowledge as part of the hiring process was a significant change to the civil service. It was also a change that sought to replace partisanship and personal connections.

To measure these skills the Act introduced an entrance examination, administered by a Board of Examiners, that would hold exams in the provincial capitals, as well as anywhere else deemed necessary by the Government. This Board was "authorized to examine all candidates for admission to the Service, and to give certificates of qualification to such persons as are found qualified, according to regulation then in force." ${ }^{\prime 197}$ This is a key formalization of the appointment process. Candidates now had to provide proof of their age with official evidence, such as their Certificate of Birth. Similarly proof of health had to be obtained from a practicising physician, and proof of character from a "certified Minister of Religion."198 Again, the process of professionalization was also a process of record-keeping. Rather than relying on personal connections, candidates had to turn to doctors and ministers, experts in their fields, for evidence of their physical and moral fitness. Keeping with the spirit of record-keeping, it

\footnotetext{
196 Ibid., 24.

${ }^{197}$ Canada, Parliament, Debates of the House of Commons, $4^{\text {th }}$ Parliament, $4^{\text {th }}$ Session, (Ottawa: Maclean, Roger, 1882, 69.

${ }^{198}$ Canada, Board of Civil Service Examiners, Rules and Regulations of the Board of Civil Service Examiners, (Ottawa, 1882), 4.
} 
was also specified that the examinations were written. ${ }^{199}$ No logic was given for this, but it seems to indicate a drive for documentation. A stamp was created for the Civil Service Board, which was to be put upon the completed examinations. The formalization of the appointment process suggests the uroboric nature of state formation. A government body was created to manage, govern, and formalize the hiring of government employees. The stamp was an official symbol that showed the paper was officially recognized.

A preliminary examination, which could be taken in English, French, or both, was instituted to test the applicants' knowledge of "of orthography and elementary arithmetic, and whether his handwriting is such as to justify his admission to the qualifying examination." Even though the passage assumed male applicants, women were also expected to take the examination. ${ }^{200}$ This again stresses the construction of the civil service as a masculine career, even as it was formally opened to women. There were also class assumptions here. To have the requisite writing and math skills, applicants needed at least some education. The requirements did not specify educational levels, but they demanded skills that were largely part of a high school education. Furthering a classed component, applicants were required to pay two dollars to take the preliminary examination. ${ }^{201}$ The logic of this preliminary examination was to avoid wasting the examiners' time with unsuitable candidates. The logic of holding two examinations is less significant, than the fact that it implemented a standard for the minimum abilities required for a achieving a position. This was the first time in the Canadian civil service that the qualities of a suitable appointee were formalized.

\footnotetext{
199 Ibid., 1.

${ }^{200}$ Parliament, Sessional Papers, 1881, 29.

${ }^{201}$ Board of Examiners, Rules and Regulations, 1882, 4.
} 
After passing the preliminary examination, a candidate could be tested by the Board of Examiners, to ascertain "that he is free from any physical defect or disease which would be likely to interfere with the proper discharge of his duties; also that his character is such as to qualify him for the Service."202 The candidate's body was officially examined for a second time. It no longer sufficed for candidates to be qualified, or politically deserving, or have a physician's proof of health, they also had to physically embody the characteristics of a civil servant. ${ }^{203}$ A civil servant's age and physical fitness were further discussed and evaluated in the planning for superannuation. Establishing a safety net would allow the government "to replace, by active, energetic men, those who are worn out in the service, whom the Government would hesitate to dismiss without giving them a retiring allowance."204

The physical examination also highlights the contradictory impulses of processes of professionalization. Despite the move toward standardizing qualifications, we can still see a vague and intangible aspect to what made a good civil servant. It was left to the examiners to decide whether an applicant's character was suited for the civil service. In a period of standardization, with an emphasis on measurable and define qualities, a candidate's character, rather than ability, was a still one of the qualities of a deserving civil servant. This irony is underscored by the fact that a doctor's certificate needed to be buttressed by the examiners' review.

\footnotetext{
${ }^{202}$ Parliament, Debates, 1882, 69.

${ }^{203}$ As the work of Michel Foucault and Timothy Mitchell stress, power is often related to the supervision, regulation, and disciplining of the a subject's body. Foucault, Knowledge/Power, 57-58; Mitchell, Colonising Egypt, 100. This will be explored in more detail in Chapter Six.

${ }^{204}$ Canada, Parliament, Debates of the House of Commons, $5^{\text {th }}$ Parliament, $1^{\text {st }}$ Session (Ottawa: Citizen Print, 1883), 793.
} 
The relative lack of formalized characteristics for appointment and the institution of an entrance exam rather than a competitive one led to a great deal of criticism of the Civil Service Act. Casey lamented that the "Bill does not embody the great radical principle in the method of appointing civil servants which we expected it would, namely, that of competitive examination. ${ }^{205}$ Edward Blake, a Liberal MP, took this criticism even further and suggested that the informal nature of the exam was meant to enable partisanship. Of Hector Langevin, a Tory MP and the Secretary of State, he asked: "You do not think they will be colorable examinations - the color blue, for example?"206 Langevin replied to the suggestion by pointing to the democratic qualities of the qualifying examination. He stated:

I have no doubt that there will always be politics connected with appointments made by any Government. I have yet to see a Government which will appoint its opponents in office. As a rule, a Government appoints its friends; but in this case all, whether friends or foes, have to pass the examinations, and they will all be treated alike, because the examinations will be conducted not by political men, not by the Ministers or their friends, but by men who will have no interest one way or the other but to see whether the person who comes up examination is qualified for it, and if he is, he will get his certificate. ${ }^{207}$

While responding to the a partisan criticism, Langevin underscored the tensions between political aspirations and reforming tendencies, that were so common to debates over the nature of civil servant appointments. Langevin also demonstrated how the professionalization of the civil service was a gendered and socio-political process. Langevin, like most other commentators, assumed the civil servants would be men. It was also assumed that these men would be of a class and background to have personal connections with politicians. Despite the language of improvement and democracy, this process was still one of reciprocity, and one of consolidating bourgeois class interests.

\footnotetext{
${ }^{205}$ Parliament, Debates, 1882, 71.

${ }^{206}$ Ibid., 794.

${ }^{207}$ Ibid., 794.
} 
The political rhetoric and circumstances of the period were full of contradictions as politicians attempted to maintain their traditional avenues of power while adapting to increasingly popular ideas of professionalization.

Langevin similarly reflected this tension between standardization and personal characteristics in a discussion of the examiners themselves. George William Ross, the Liberal MP from Middlesex, Ontario, compared the proposed reform bill to that of Senator Pendleton's in the United States. In the Pendleton Bill, a penalty was imposed on examiners for acts of partiality or favoritism. Langevin disagreed. Since, "the examiners will be men of good position and well qualified in the discharge of their duties," and the government "will have the right to remove them with a stigma attached to any misconduct," there were enough provisions in place. ${ }^{208}$ In Langevin's view personal characteristics and appeals to honor were better suited to regulate the examiners' behavior than formal rules. He reiterated this point, stating that "the best guarantee is the honor of the man himself." Similarly, Langevin was against having an official oath for the examiners, because “they may be sworn, but I rely more on a man's honor than upon his oath. If he is dishonorable he makes his oath as well." Even as they were forming an official board to oversee and regulate the entrance process and measure candidates personal, intangible qualities were part of the political vision. Langevin then turned the reforming rhetoric on itself, suggesting that "Confidence is reposed in clerks in commercial houses or in public offices, and a certain amount of confidence must necessarily be reposed in men in the [examiners]. ${ }^{209}$ As noted earlier, Casey and other reformers wanted the civil service to be run like a business, rewarding those who proved

\footnotetext{
${ }^{208}$ Ibid., 1122.

${ }^{209}$ Ibid., 1123, 1124. This logic of public honour and reputation was important to William Kingsford and explored in the next chapter.
} 
themselves deserving. Here Langevin was using a similar logic, but to argue the opposite point. Even as administration was becoming more formal and regulated, there was space for personal and partisan influence.

Ross accused Langevin of "allowing the matter to be initiated in a very loose way." 210 This flexibility allowed the governing party to appeal, at times, to both reforming and partisanship rhetorics. In an exchange with John A. Macdonald, Casey suggested that replacing patronage with competitive exams "may perhaps be a subject on which there is a difference of opinion between himself and those whom he has to consult." ${ }^{211}$ This criticism is echoed in Bill Doherty's Slaves of the Lamp. Doherty argues that "patronage may have suited the political parties but it didn't suit the service."212 These statements suggest that the failure of the 1882 reform to eliminate patronage was the result of cynical partisanship and corruption by the Tory politicians. This is certainly a reasonable criticism, as the Conservative leadership was savvy, and at times corrupt. When placed in the context of the debates at the end of the $1870 \mathrm{~s}$, however, these modest reforms seem to reflect the variety of stances expressed by politicians and a public that both supported them and was also still actively seeking patronage.

One area where patronage was still actively sought was in departments away from the national center. Although the language in the Civil Service Act refers to all departments, the rules governing civil servants, and the qualifying examinations for appointment were only enforced in the inside service. This suggests the chasm between federal initiatives and their implementation at the local level. Matthew Hannah argues that both colonial and national governments "involve the making of decisions in distant

\footnotetext{
${ }^{210}$ Ibid., 1124.

${ }^{211}$ Parliament, Debates, 1881, 1397.

212 Doherty, Slaves of the Lamp, 14.
} 
centers which affect local conditions of life for the subjects or citizens," which in turn create vertical relationships between decision-makers and the local communities they govern. ${ }^{213}$ In the case of Canadian civil service reform this led to local and provincial resistance to reform. This friction was further motivated by the concerns over the unrepresentative character of the state bureaucracy. Immediately following Confederation, and continuing into the 1880 s, people in the Atlantic Provinces and Quebec were critical of the abundance of positions being granted to Ontarians. ${ }^{214}$ As Chapter Five will argue, religious and linguistic issues were part of these concerns over allocation. Some French Canadians and Roman Catholics stated that they were underrepresented both in federal positions and their own communities. ${ }^{215}$ Appealing to their MPs was one method that enabled to access political power and secure employment. By exploiting this politicians could secure support, even as they promoted and championed reforms at the national level.

An 1883 petition from PEI highlighted the perceived inequality in appointments, but in reference to the island's relationship with other Atlantic provinces. It complained that the several positions, including Inspector of Inland Revenue, Inspectors of Customs, and Inspectors of Post Offices, had "been merged into the Nova Scotia office." Instead, they "claim[ed] as a right that the Provincial head of every department should be a resident of the Island." 216 The petition highlighted how attempts to make the service more efficient clashed with local needs and expectations. To the critics in PEI this was a

\footnotetext{
${ }^{213}$ Hannah, Governmentality and the Mastery of Territory, 114.

${ }^{214}$ Hodgetts, The Canadian Public Service, 35.

215 The beginning of this dissatisfaction in Quebec is traced in Gilles Paquet et Jean-Pierre Wallot, Patronage et pouvoir dans le Bas-Canada (1794-1812) (Montreal: Les Presses du l'Université du Québec, 1973). It was exacerbated by concerns over the declining French population and out migration throughout the 1860s. The dissatisfaction of Roman Catholics is also especially voiced in letters to Tupper.

${ }^{216}$ LAC, Macdonald Fonds, vol. 332, Charlottetown to Macdonald, 3 August 1883,145108.
} 
political issue as much as an administrative one. The petition argued, "We entered confederation upon an equal footing in this respect with the other province and though immediately after the union our right was reorganized it would appear as if lately it is the policy of the Government gradually to reduce the Civil Service here and make us a Department of either Nova Scotia or New Brunswick."217 This was not expressed in terms of patronage or reciprocity, but those of political equality. Having a functioning civil service to administer the region and positions to give to people in the region was related to the province's autonomy. Following the Civil Service Act of 1882, ideas about administration still brushed against those of political questions of equality, autonomy, and local expectations. The civil service was still a politicized issue, even as reforming ideals took hold.

The Canadian civil service, and state apparatuses in general, underwent significant material and discursive changes throughout between 1867 and 1882. The image of an ideal civil servant and the appointment process for that servant were transformed and specified. On the one hand this was a re-imagining that replaced reciprocal patron-client relations with ideas of the competitive, democratic professionalism. The aim of the Civil Service Board was to counter patronage's pernicious influence, blaming it for

admission to the Service of those who are too old to be efficient; of those whose impaired health and enfeebled constitutions forbids the hope that they can ever become useful public servants; of those whose personal habits are an equally fatal objection; of those whose lack of education should disqualify them; and of those whose mental qualities are of an order that has made it impossible for them to succeed in private business. ${ }^{218}$

\footnotetext{
${ }^{217}$ Ibid.

${ }^{218}$ Parliament, Sessional Papers, 1881, 16.
} 
The new image of a civil servant was an active, educated, qualified candidate, rather than a political crony. This new image, was also, still a middle-class male. While adding ability to the appointment process this is also a further entrenchment of gendered and classed assumptions, even as women were officially made eligible for certain low-ranked positions.

The processes of professionalization were further complicated by the ongoing efforts of politicians and the public to continue patronage. It was useful to politicians as a method to reward supporters and to win elections. The public across the country also continued to seek appointments through connections. This is not to suggest that the reforms of 1882 were failures, but rather to place them within ongoing processes of social and political ordering. Even though they did not eliminate patronage, civil service reforms were important steps in establishing an expanding and professional Canadian civil service. Debates and conflicts over the nature of the civil service and how to manage partisan influence continued throughout the 1880 s, culminating with another Royal Commission on the Civil Service in 1891-1892. The shifts outlined in this chapter set the rhetoric in which these debates took place. 


\section{Chapter 3}

\section{A Question of Public Import: Partisanship, the 'Public Man,' and the Kingsford- Langevin Affair}

His usefulness was gone, the office was no longer required and therefore it was abolished, and Mr. Kingsford left the Service. ${ }^{219}$

Sir Hector Langevin, 1881, in Parliament

In 1881, William Kingsford "left" the civil service under acrimonious terms. He documented his leaving in Mr. Kingsford and Sir H. Langevin, The Case Considered with the Official Correspondence: A Memoir for the Historian of the Future, a document that, like the Commissioner's report on the Civil Service published at the same time, highlighted the tensions between professionalization and partisanship in the service.

Kingsford was born in England in 1819. He came to Canada in 1838, as part of the forces sent to suppress the Lower Canadian Rebellion. While in the military, he learnt techniques of land surveying. He was appointed the deputy city surveyor of Montreal in 1842. Kingsford went on to become a civil engineer, a railway advisor, and, in his spare time, a journalist. In 1870, Kingsford was given a position in the Department of Public Works overseeing various surveys of harbours and rivers under federal control. ${ }^{220}$ Despite his nearly forty years as a civil engineer, Kingsford is best remembered for the historical work he published after his career in the Civil Service - the multivolume History of Canada. ${ }^{221}$

William Kingsford died in September 1898. Shortly after, the Canadian Magazine published a eulogy, titled "A Canadian Historian: A Sketch for Mr.

\footnotetext{
${ }^{219}$ William Kingsford, Mr. Kingsford and Sir H. Langevin, The Case Considered with the Official Correspondence: A Memoir for the Historian of the Future (Toronto: R.G. McLean, 1882), 16.

${ }^{220}$ M. Brook Taylor, "Kingsford, William," Dictionary Canadian Biography Online, http://biographi.ca/009004-119.01-e.php?id nbr=6196, last accessed 2 July 2013.

${ }^{221}$ William Kingsford, The History of Canada, vol. 1-10 (Toronto: Rowsell \& Hutchison, 1887-1898).
} 
Kingsford." The title suggests that his history was his primary accomplishment: "the History of Canada is Dr. Kingsford's monument. It is there that the man is to be found, and those who would know him must seek the knowledge not in the meager notice of personal traits here given, but in the pages in which are written the story of this Dominion." ${ }^{222}$ Based on extensive archival research, it was an account of the military, constitutional, and political history of the British North American colonies, from their founding to the establishment of responsible government. As a historian, Kingsford was praised by his eulogist for his "loyalty to the truth, courage and independence." 223 Reviews of the volumes as they were published similarly heaped praise on Kingsford's methods, and testified to his rigorous approach. Reviewing the second volume, for example, an article in Canadiana noted that Kingsford was "earnest in the search for the truth, fearlessly independent in expressing his opinions." The review attributed the volume's strength to the "the wealth of testimony with which, at much trouble and expense, he has supported his views and illustrated his theories, is worthy of all commendation. ${ }^{224}$ These passages underscored the importance accorded empirical evidence and personal authority in writing a history.

Although written for a different purpose, Kingsford's history shared many traits with the Civil Service Commissioner's report of 1881. History of Canada was the work of a Victorian intellectual, and its critical reception showed the ongoing interactions between political and personal authority. ${ }^{225}$ After the publication of the History's fourth

\footnotetext{
${ }^{222}$ R.W. Shannon, “A Canadian Historian: A Sketch for Mr. Kingsford," The Canadian Magazine, Vol.12, no.3 (January 1899), 194.

${ }^{223}$ Ibid., 192.

${ }^{224}$ John Reade, “Canadian Histories,” Canadiana, Vol. 1, no. 1 (Jan. 1889), 13.

${ }^{225}$ These traits also put Kingsford in the same category of middle-class cultural leaders documented in latenineteenth century biographical dictionaries. In his study of these collections, Robert Lanning notes that these biographies often stressed the "intellectual wholeness" of these cultural leaders, whose "moral and
} 
volume, The Dominion Illustrated made this link between Kingsford's personality and his methods even more clearly: "from its inception the author has proceeded calmly in the independent investigation of every event with which he has had to deal, unswayed by tradition or prejudice or any motive save that of ascertaining the truth and placing it fairly before the hands of his readers. ${ }^{, 226}$ This review noted Kingsford's modern approach to the past. His investigation was anchored in his rationality. He was calm, independent, and unbiased. Robert Lanning notes that this historical approach was connected an "everimproving future. ${ }^{, 27}$ To legitimate this future, nineteenth-century promoters, such as William Kingsford and his readers, attempted to build links to the past.

Kingsford consciously worked to cultivate an image of progressive Victorian masculinity. In scrapbooks, he kept records of his ideas, projects, and interests. ${ }^{228}$ In both his early career as an engineer and his later life as historian and public intellectual, he relied on presentations of professionalism, reason, and empiricism. The Canadian Magazine noted that, at times, this dedication led to a "a certain intellectual rigidity which prevented him from doing full justice to that side of the case which was alien from his sympathies." ${ }^{229}$ The magazine went on to suggest that this non-conciliatory and

\footnotetext{
intellectual unity working in tandem with material culture." Robert Lanning, The National Album:

Collective Biography and the Formation of the Canadian Middle Class (Ottawa: Carleton University Press, 1996), 49.

${ }^{226}$ The Dominion Illustrated, Vol. 5, no. 128 (Dec. 13, 1890), 397.

${ }^{227}$ Lanning, The National Album, 60. Alan Gordon's study of historians' uses of Jacques Cartier makes a similar link between nationalist goals and national history. Although historians were largely middle-class intellectuals, this identity and history was meant to have broad social appeal. Alan Gordon, The Hero and the Historians: Historiography and the Uses of Jacques Cartier (Vancouver: UBC Press, 2010), 3. Catherine Hall has examined the work of Thomas Macaulay in relating British history to the creation of white, liberal subject. She noted that his "His male readers were invited to identify with the values of education, industry, and independence, manly virtues, while his female readers could identify with familiar, domesticated, polite forms of femininity." Catherine Hall, "Macaulay: A Liberal Historian" in Simon Gunn and James Vernon, eds., The Peculiarities of Liberal Modernity in Imperial Britain (Berkeley: University of California Press, 2011), 25.

${ }^{228}$ Archives of Ontario, William Kingsford Fonds, F 1016.

${ }^{229}$ Shannon, "A Canadian Historian," 192.
} 
stubborn attitude might have been the cause for "the treatment Dr. Kingsford received from Sir Hector Langevin, Minister of Public Works in the Macdonald Government."230

Kingsford's departure from the service is typically an affair glossed over by historians, but it is highly relevant to this dissertation. ${ }^{231}$ Kingsford had been employed in the federal government's Department of Public Works since 1870 as an engineer in charge of public harbours in Ontario and Quebec. Following the Conservative Party's returned to power in 1878, Hector Langevin, the new Minister of Public Works, dismissed Kingsford in the rather unceremonious terms that opened this chapter. Kingsford challenged his dismissal. At first he wanted to be reinstated. When this seemed unlikely, he asked for a year's pay of $\$ 3,300$, and eventually asked for a half-year's salary.

While Kingsford's dismissal was high profile and well documented, his situation was not unique. In this period other civil servants were fired for interfering in politics. ${ }^{232}$ This was a particularly contested issue because what constituted political action was not yet standardized, so civil servants were at the mercy of politicians. ${ }^{233}$ Kingsford went so far as to publish a pamphlet about his dismissal, aware that it was unlikely he would change the government's mind. More than just appealing to public opinion, he hoped that in documenting the affair "the historian may turn to it in the future and conceive that it

\footnotetext{
${ }^{230}$ Ibid., 193.

${ }^{231}$ It is mentioned only in passing in Martin Brook Taylor's study of Canadian historians, Promoters, Patriots, and Partisans: Historiography in Nineteenth-Century English Canada (University of Toronto Press, 1989), 261-262. Similarly, it is not mentioned in Douglas Owram's history of the Department Public Works, Building For Canadians: A History of the Department of Public Works, 1840-1960 (Public Relations and Information Services, Public Works Canada, 1979). This absence is somewhat surprising, since there is an entire chapter on Langevin's time as Minister of Public Works that focuses on patronage and scandals.

${ }^{232}$ According to Douglas Owram, Langevin was particularly interested in maintaining "a friendly staff" in Public Works, Building For Canadians, 123-124.

${ }^{233}$ Canada, Parliament, Debates of the House of Commons, $4^{\text {th }}$ Parliament, $1^{\text {st }}$ Session, vol. 1 (Ottawa:

Citizen Print. and Pub. Co., 1879), 551.
} 
presents a phase of official life which in a few sentences, he may deem it expedient to perpetuate. $" 234$ This chapter seeks to do just this, albeit not in pursuit of the truth behind Kingsford's dismissal as he wished when he published his pamphlet in 1882. Instead, this chapter argues that the rhetoric on which Kingsford and others relied was reflective of Canada's political culture in the late 1870 s and early 1880 s and examines how this rhetoric operated in the context of civil service reform and that the previous chapter outlined. As we shall see, private and public issues, and ideas of patronage and professionalism continued to interact. Furthermore, in publishing the pamphlet Kingsford made a personal issue, that of his employment, a public matter. This reflected a Victorian belief in public debate and empiricism. ${ }^{235}$ It also reinforces the changing roles and expectations for civil servants, who existed in both professional and partisan worlds.

\section{The Dismissal}

The reasoning for the firing was unclear. Langevin originally claimed that Kingsford's post was no longer necessary due to departmental reorganization. In 1879

\footnotetext{
${ }^{234}$ Kingsford, Memoir, 14.

${ }^{235}$ This emphasis on empiricism corresponded to the rationalism that many scholars suggest was central to the emergence of the bourgeois public sphere in the nineteenth century. This work is often inspired by the thought of Jurgen Habermas, who argued this public was based on presumed, if not actual, equality a dedication to reason, and the problematization of taken-for-granted assumptions. Craig Calhoun, "Introduction: Habermas and the Public Sphere" in Calhoun, ed., Habermas and the Public Sphere (Cambridge, Mass: MIT Press, 1992), 12-13. This is also the type of rational, empiricist public outlined in Jeffrey L. McNairn, The Capacity to Judge: Public Opinion and Deliberative Democracy in Upper Canada, 1791-1854 (Toronto: University of Toronto Press, 2000). These rational men met in voluntary associations, shared newspapers, and debated public opinions. That McNairn explores men in the public sphere is not a coincidence. As Nancy Fraser has argued, however, access to these cultural products was largely limited to bourgeois men. Furthermore, this ideal public excluded "subaltern counterpublics" such as women, minorities, and workers, whose interests were marginalized by being designated 'private.' Nancy Fraser, "Rethinking the Public Sphere: A Contribution to the Critique of Actually Existing Democracy" in Calhoun, Habermas and the Public Sphere, 123. Similarly, Darren Ferry has been critical of the class politics of these Canadian voluntary associations. He suggests that "[w]hile embracing the concept of inclusiveness, voluntary associations could also be highly exclusive, as witnessed in the class discord inherent in agricultural organizations, the 'professionalization' of scientific and literary societies, the 'selective intolerance' of fraternal orders, the tensions over gender issues in temperance societies." Darren Ferry, Uniting in Measures of Common Good: The Construction of Liberal Identities in Central Canada, 1830-1900 (Montreal and Kingston” McGill-Queen's University Press, 2008), 287.
} 
Railways and Canals was made a separate department from Public Works. ${ }^{236}$ There was no position for Kingsford in either department. Martin Brook Taylor, who has written on Kingsford's historical contributions, suggests that in serving under Liberal Prime Minister Alexander Mackenzie "Kingsford unwittingly became the author of his own misfortune."237 Moreover, Kingsford was vocal in his personal and professional admiration of Mackenzie, whose stern demeanor and personal industry matched Kingsford's worldview. One of his obituaries conceded that Kingsford's position would likely have been secure if he had "preserved a judicious silence with regard to his political opinions at a time when party feeling ran high, and when the expression of strong sympathy with the fallen Premier by a civil servant occupying a conspicuous position would naturally be resented."238

In addition to partisanship, other reasons were given for Kingsford's dismissal. Kingsford himself listed several reasons that had been made known to him: "Sir H. Langevin's assertions are that my duties were no longer to be performed; that money was saved by my dismissal; that six month's pay was readily given me; that he had but a certain number of assistants; that my office had been abolished."239 This focus on economic reasons and reducing the size of the civil service would have been resonant at the time. As we have seen, the introduction of ideas from business management - notably efficiency and economy - were popular parts of civil service reform. In Parliament, Langevin alluded to these tropes in distinguishing between those dismissed and those

\footnotetext{
${ }^{236}$ Previous to this division, railways were the main Public Works project. The new alignment pushed projects from the periphery to the department's focus (i.e., government buildings, dredging, harbours and rivers that were not part of a canal). Owram, Building for Canadians, 140.

${ }^{237}$ Brook Taylor, Promoters, Patriots, and Partisans, 262.

${ }^{238}$ Shannon, "A Canadian Historian," 193.

239 Kingsford, Memoir, 14.
} 
discharged. The former is when "a man is sent away for good cause," while the latter means "he was not required any longer, though he might be a very good man." 240 To be discharged was then related to efficient management and not performance or discipline. Langevin insisted that Kingsford was discharged. To further this point he explained that engineering positions were also eliminated in New Brunswick, Nova Scotia, and throughout Ontario. ${ }^{241}$ Neither Kingsford nor his supporter, the recently-unseated Prime Minister, Alexander Mackenzie, accepted these reasons for his dismissal. Mackenzie called the rearrangements "a farce" designed to "legislate Mr. Kingsford out of his position."242

It is impossible to know the actual reason for his dismissal. It is likely, though, that charges of partisanship would have been deeply offensive to Kingsford, who presented himself as a rational professional - an empiricist above the petty interests of party politics. ${ }^{243}$ In an American context, Matthew Hannah refers to the late-nineteenthcentury professionalizing civil service as made up of "public men of affairs," who understood impartiality as "a matter of personal reputation and a product of moral conduct." 244 To defend himself and contest his dismissal, Kingsford relied on the same tenets of empiricism and public rationality as he did in his historical work. He did this by appealing to the public through the aptly titled Mr. Kingsford and Sir H. Langevin, The Case Considered with the Official Correspondence: A Memoir for the Historian of the Future. This pamphlet was a collection of the correspondence between Kingsford and

\footnotetext{
${ }^{240}$ Ibid., 16.

${ }^{241}$ This reasoning was somewhat convenient for Langevin, since both he and Mackenzie admitted to not being aware of any engineers in New Brunswick. Langevin added, "as soon as I discovered it I dismissed them all." Kingsford, Memoir, 17.

242 Kingsford, Memoir, 25.

243 Taylor, Promoters, Patriots, and Partisans, 262.

${ }^{244}$ Matthew G. Hannah, Governmentality and the Mastery of Territory in Nineteenth-Century America (Cambridge: Cambridge University Press, 2000), 63.
} 
Langevin and relevant excerpts from the Hansards. Kingsford sought to lay out his case for both public and historical judgment, and hoping both would side with him. Sadly for Kingsford, however, his eulogists and biographers frequently overlook this chapter from his life. His obituary simply explained that "To this event, which Dr. Kingsford felt at the time was a cruel blow, we in large measure owe the "History of Canada." ${ }^{, 245}$ More recently, Martin Brook Taylor includes Kingsford in his study of nineteenth-century English historiography in Canada. In a single paragraph he outlines Kingsford's dismissal, concluding: "Blocked by the government from further participation in major nation-building projects, too proud and perhaps too old to find the lesser assignments of private contracting rewarding, Kingsford turned, rather surprisingly, to writing the history of Canada." ${ }^{246}$ Yet both the firing and Kingsford's response to it are deserving of more explicit focus because of what they teach us about the political culture and public sphere of the late-Victorian period. While Kingsford's biographers feel this was a minor episode in an otherwise full, productive life, Kingsford himself likely felt otherwise in 1882.

\section{The Pamphlet}

A Memoir for the Historian of the Future opened by linking individual and public interests. Kingsford explained that he was "aware that what is known as individual wrong seldom obtains either sympathy or consideration with the great mass of men." Other than a "momentary feeling of regret, a passing spasm of indignation that injustice should have been committed," a personal issue could not be expected to maintain public interest. ${ }^{247}$ This was a problem, according to Kingsford, because this brief interest was precisely what allowed politicians to consider "a line of conduct which his interest or his vanity

\footnotetext{
245 Shannon, “A Canadian Historian,"193.

246 Taylor, Promoters, Patriots, and Partisans, 262.

${ }^{247}$ Kingsford, Memoir, 1.
} 
may dictate, and which his conscience or his experience may tell him will call forth stern criticism when it is first made public." ${ }^{248}$ This passage is instructive of Kingsford's professionalized view of politics and administration. He identified 'interest' and 'vanity' as motivations that would lead to criticism if public attention was sustained. The implication being, especially in the latter, that they conflicted with a rational construction of public good. Kingsford seemed to understand that political authority was shifting, if unevenly, from politicians to the public they represented. Kingsford's memoir was appealing to an authority above partisanship. In bringing public attention to the issue Langevin could be held accountable for his actions. This is also an example of Kingsford's historical approach. He presented evidence, from personal and official archives, to document his case. Rather than describing his character explicitly, Kingsford's memoir presented evidence for public evaluation that would allow the readers to come to a (correct) conclusion themselves.

Although dealing with a personal matter - his employment - Kingsford classified this as an instance when "so important a principle lies at the base of individual wrong...that the whole heart of the community is stirred and awakened." 249 Politicized dismissals from the civil service were not uncommon in this period. ${ }^{250}$ Resulting from his interest in journalism and his long career, however, Kingsford was in a unique position to appeal to public and democratic sentiment. To support his claim, Kingsford relied on Victorian ideals of respectability and independence. He described himself as having

\footnotetext{
248 Ibid.

${ }^{249}$ Ibid., 4.

${ }^{250}$ For example, Régis Cardinal was accused of canvassing for the Liberals and dismissed by the Conservative Government after the election of 1878. More generally, Charles Tupper suggested that "whenever it could be shown that a public officer, instead of attending to his duties, gave his time and attention to political work, he should be dismissed." Parliament, Debates, 1879, 551.
} 
"only his cause and truth to sustain him." Langevin, on the other hand, was "in office, with power, with Ministers at his side interested in his character being cleared, with a political party to whitewash him by a vote, with numerous class of retainers and adherents ready and obsequious to do his bidding." ${ }^{, 251}$ More than presenting himself as the overwhelmed underdog in the dispute, Kingsford was also outlining the changing relationship between reason, politics, and professionalism. If Kingsford was dismissed for partisanship he was a victim of the older 'victor-spoils' approach to administration. As he suggested, this approach relied on privilege and authority. To counter this, Kingsford attempted to arm himself (and his readers) with 'truth. ${ }^{252}$

That Kingsford was contesting ministerial authority underscores the reasoning relied on by reformers. Professionalization of the civil service was tied to its democratization. Rather than being governed by the whims of politicians, Kingsford and other reform-minded actors appealed to and based their claims in public opinion. In Imagining the State, Mark Neocleous uses a corporeal metaphor to explain this process. Democratic politics, he argues, entails "a disincorporation of the body politic, which begins with either a literal or metaphorical decapitation." ${ }^{, 53}$ No longer is authority held by a leader, but rather by an imagined public. In challenging Langevin, the Minister of

\footnotetext{
${ }^{251}$ Ibid., 4.

${ }^{252}$ As we will see in the next chapter, this distinction between appointments based on personal characteristics and those based on quantitative data continued to be flexible and highly debated into the 1890 s.

${ }^{253}$ Mark Neocleous, Imagining the State, (Maidenhead: Open University Press, 2003), 23. Neocleous draws from the work of Simon Critchley to make this point. Simon Critchley, "Re-tracing the political," in David Campbell and Michael Dillon, eds., The Political Subject of Violence (Manchester: Manchester University Press, 1993).
} 
Public Works, Kingsford was appealing to a public that existed outside the state and a public that ought to act as a moral authority for the state's conduct. ${ }^{254}$

Kingsford's challenge relied on the changing image of the civil service. He asked "is the public service to be made a convenience for a Minister to purchase adherents, or satisfy enmities at the public expense and to the public detriment?"255 Contrasting personal and public interest was a common rhetorical tactic in this period. As we saw in the preceding chapter, members of the public continued to expect and desire patronage as reforms began to take shape. In fact, the week after Kingsford's dismissal Arthur Gordon wrote to John A. Macdonald, explaining that since Kingsford's dismissal created an opening, he would like to be considered for Harbour Engineer. ${ }^{256}$ Nevertheless, placing patronage in opposition to public interest was an increasingly frequent tactic amongst reformers. Like those explored in the previous chapter, Kingsford also borrowed rhetoric from private business. He complained that "there is no recognition of merit, no reward for an honorable career, no encouragement to industry, and to devotion of duty;" instead "subserviency and political influence" were rewarded. ${ }^{257}$ This noble ideal civil servant identified by Kingsford fit with that described by reformers throughout the 1880s. An 1886 article in the Globe championed reforms that encouraged "as far as may be appointments by merit, promotions by merit, a fair's day work for a fair's day pay by a reduced and efficient staff." 258 There is some irony in the fact that Langevin also relied

\footnotetext{
${ }^{254}$ As Chapter Five will argue, depending on the writer and on the circumstances, many different publics were imagined as being the basis the political authority.

${ }^{255}$ Kingsford, Memoir, 4.

${ }^{256}$ Library and Archives Canada (hereafter LAC), Sir John A. Macdonald Fonds, MG26-A, vol. 364, Arthur Gordon to Macdonald, 7 January 1880, 168754. That Gordon would have heard of the dismissal and that there was an opening lends credence to the notion that Kingsford was removed for partisan issues, and not as Langevin would eventually claim, because of a reorganization.

${ }^{257}$ Kingsford, Memoir, 12.

${ }^{258}$ The Globe, 13 December 1886, 6.
} 
on ideas of reduction and efficiency to justify dismissing Kingsford. ${ }^{259}$ This also shows, though, how flexible stances were in this period. Politicians, administrators, and wouldbe civil servants frequently expressed contradictory ideas as they all attempted to maneuver through a changing political landscape.

Kingsford's example is interesting because he was less concerned with overall reforms than in his own claims. He described a better system as being one where "the public service is to be conducted honestly, ably, and justly with benefit of the State, and to the advancement of good government and the public interest." ${ }^{, 260}$ In such a system "[w] hether men who, loyally fulfilling their obligations, are to be protected by the aegis of public opinion, in their position, so long as they perform their duty honorably and satisfactorily." This suggests that even among those who were interested in professionalization, personal and intangible characteristics were important parts of public service. Satisfaction and honour were the same types of references used in patron-client relationships. Kingsford was limited by what Thomas Blom Hanson and Finn Stepputat called the "language of stateness." 261 The continuous processes of state formation were reliant on widespread practices of governance and authority. Even though Kingsford was dissatisfied with the existing system, he was unable to suggest one that relied on different constructions of service. The main difference that he identified was a public service that was answerable to the public rather than to politicians. This fits with the processes of democratization. Despite this ostensible democratization, however, it is still a stance that

\footnotetext{
${ }^{259}$ In general, Langevin was regarded as interested and skilled at managing Public Works, which meant being interested in efficiency and economy. Owram, Building for Canadians, 124, 162.

${ }^{260}$ Kingsford, Memoir, 4.

261 Thomas Blom Hanson and Finn Stepputat, "Introduction: States of Imagination," in Hansen and Stepputat, eds., States of Imagination: Ethnographic Explorations of the Postcolonial State (Durham: Duke University Press, 2001), 5. Hanson and Stepputat draw from Pierre Bourdieu, and refer to this "language of stateness" as an example of state capital, which has "the (meta)authority to validate or invalidate other forms of authority, that is, to have the last word in a territory, to have the last judgment" (6).
} 
relies on existing constructions of honour, respectability and service. These definitions continued to exclude a large portion of the public from public service and public debate.

Even as Kingsford referred to increasingly technical and professional language, his memoir still frequently relied on moral claims. He criticized existing notions of patronage, explaining that "in public life there are always many inferior agents to do the bidding of their masters, who are only too willing to earn the wage of sycophancy and subserviency. The scruples of this class are light." ${ }^{262}$ This emphasized the contradictory understandings of civil service. While writing to maintain his position and making a public appeal for support, Kingsford was disapproving of other civil servants who were dependent on the support of others. This rhetoric highlighted the dependence of those reliant on patronage, and criticized it for being unscrupulous. Kingsford linked these types of relationships to general problems in the political culture. He explained that the result of such patron-client relations was that "men in a position to be mischievous, with no principle to guide or restrain them, seldom hesitate to carry out their purpose." This temptation to mischief was exacerbated by the fact that they were not held accountable for their actions, because "the interval of being called into account is long and when there are defenders in the House of Commons and elsewhere to justify their conduct or to turn aside the debate in any awkward investigation. ${ }^{263}$ Kingsford's solution was to turn to the same methods he would later use in his historical work - to provide evidence to the public and let reason decide.

In his memoir Kingsford placed himself squarely in opposition to unaccountable mischief-makers. In making his case public he made it a matter of record and public

\footnotetext{
${ }^{262}$ Kingsford, Memoir, 3.

${ }^{263}$ Ibid., 3.
} 
judgment. He stated that, "I write this with deliberation, with a full sense of the character of my language. If I make an unadvised and calumnious accusation, I should be criminally prosecuted, and I hold myself at the disposal of Sir H. Langevin to answer him as he may call upon me. ${ }^{264}$ This stressed the significance of having an official record, a publicly-accessible archive of "the facts." He was willing to be held accountable to his word, and willing to be punished if proven untrue. This was also an implied challenge to Langevin. Kingsford was challenging him to repudiate him in public and on the record. This belief in the authority of archival evidence reflects the historical consciousness and method that Kingsford would later apply to his History of Canada volumes. As with his researching and writing of Canada's history, Kingsford presented his professional life empirically to the public.

Making the case and the documents public also involved an element of performative liberalism and masculinity. This challenge placed Kingsford's position as a public man of reason in contrast with Langevin's duplicity. Later in the memoir, Kingsford made this challenge to Langevin's masculinity more explicitly. He explained that he did not understand Langevin's motives in dismissing him. He suggested that they might have been "whim, caprice, malignancy, hatred, pained vanity, or feminine fullblown pride and insolence. ${ }^{265}$ Each of these causes is marked by being irrational, and consequently feminine. Kingsford extrapolated that "the public service should be à l'abri of all such influence. ${ }^{266}$ This is a frank reminder that the processes of professionalization

\footnotetext{
${ }^{264}$ Ibid., 5 .

${ }^{265}$ Ibid., 12. In making recommendations some patrons made similar links between their support, recommendations and masculinity. In 1884, Macdonald was pressuring $\mathrm{CH}$ Mackintosh to change one of his recommendations for a government position. Mackintosh refused on the grounds that "It would look neither manly nor honest to forsake him now and to treat my pledge to those who have supplanted him." LAC, Macdonald Fonds, vol. 319, CH Mackinstosh to Macdonald, 14 July 1884, 144208.

${ }^{266}$ Ibid., 12.
} 
were deeply gendered. As the civil service was reimagined as a place of rational, democratic behaviour it reinforced that it was a space of men.

\section{Creating and Defending the Good Public Man}

A Memoir for the Historian of the Future had a specific motivation, to contest Kingsford's dismissal and to support his requests for reimbursement. The logic within this document reflects a larger issue in the period's political culture. Just as he would with History of Canada, Kingsford created a document that relied on record-keeping and publicity. As Patrick Joyce outlines in the British example, nineteenth-century liberalism relied on facts and objectivity. This was applied to arguments, but also at a personal level: "a premium was put not only on the superior rationality of what could be quantified and known statistically, but also on the person who employed statistics to think and consider." ${ }^{267}$ Joyce notes that this was both a political and a personal concern. The performance of liberalism also relied on following expectations of respectability and the constructions gentlemanly behaviour. ${ }^{268}$ These interactions between respectability and objectivity are evident throughout Kingsford's memoir. He noted that his concerns rose "above the appeal against personal wrong," becoming a question of "public import and morality, and the consideration a public issue." ${ }^{, 69}$ Consequently, in his correspondence and his pamphlet he attempted to make the record official and publicly known.

Part of Kingsford's concern with making his case public was to protect his reputation. When speaking to Parliament he made the motivation clear. He stated that "the defence of one's character is imperative, and I must say that in this case I find

\footnotetext{
${ }^{267}$ Patrick Joyce, The Rule of Freedom: Liberalism and the Modern City (London: Verso, 2003), 26.

268 Ibid., 124.

${ }^{269}$ Kingsford, Memoir, 4.
} 
reputation has not only been questioned, but assailed." ${ }^{270}$ This was both a personal and a professional concern. Since "a public department is a small world," and "anything extraordinary runs through it like wildfire," it was likely that the news of the accusations would spread quickly, and uncontrollably. ${ }^{271}$ One consequence of this was that Kingsford claimed he knew of the Langevin's intention to dismiss him two hours after Langevin made his intentions known in a letter. Another consequence was that others would be aware of the situation. According to Kingsford's records, Langevin had originally claimed that Kingsford was a patronage recipient under the Liberal government. This would likely have offended Kingsford's sense of independence. In the same debate, Langevin expressed concerns about his own reputation, but in regard to parliamentary procedure and privilege. Responding to Mackenzie and Kingsford's allegations he stated: "there is another thing. The hon. gentleman said the reason I was giving was not an honest reason. I do not think that is very complimentary to any Member of Parliament. ${ }^{, 272}$ This was more indicative of the deference expected by MPs, than concerns for professional reputation. Both of these concerns underscored the importance of respectability in public interactions. This deference was an important element in patron-client relationships. As these relations were replaced with regulated processes, the interactions between politicians and administrators also shifted. Kingsford's challenge to Langevin became more than a personal claim; it reflected the changing basis of authority in public administration.

As we have seen, Kingsford referred to patron-client relationships in highly critical terms, making reference to service and corruption. Kingsford also complained

\footnotetext{
${ }^{270}$ Ibid., 23

${ }^{271}$ Ibid., 7.

${ }^{272}$ Ibid., 16-17
} 
that "A paper...in the County of Bruce called me a 'Grit Agent.",273 This was an affront to Kingsford's ideas of professionalism. Amongst the reformers throughout the $1870 \mathrm{~s}$, partisanship became increasingly linked with irrationality and bias. Again, this accusation was personally damaging to Kingsford, as it cost him his position. It also fit with broader concerns about respectability and reason. Kingsford referred to these claims as "falsehoods the most systematic uttered by men to whom I did not speak, to suit their own ends." He concluded, "I heard all these things and treated them with contempt."274 To link the accusations against him with the personal interests of his accusers further underscored the difference between public and partisan good. The implication is again that Kingsford was a professional, motivated by reason and the public good, while Langevin and his allies were motivated by partisanship, and other less noble causes.

The accusation of Liberal partisanship was made all the more frustrating to Kingsford because the opposite claim was made against him while the Liberals, under Alexander Mackenzie, were in power. He claimed there were several instances when he was reported as "acting in the interests of the Conservative party," and Mackenzie was warned, "that I was endeavoring to embarrass him."275 Again Kingsford repudiated this with reference to his learned professionalism. He explained: "Every Government engineer knows it is a mode with a class of contractors and their agents to prosecute their claims and to avoid their responsibility in this form." ${ }^{276}$ The professionalizing rhetoric implied non-partisanship, but for political aims. Kingsford's generalization posited

\footnotetext{
${ }^{273}$ Ibid., 8.

${ }^{274}$ Ibid., 11.

${ }^{275}$ Ibid., 11.

${ }^{276}$ Ibid., 11-12.
} 
engineers as disinterested workers, letting others address political issues. ${ }^{277}$ As argued in the preceding chapter, however, this was also a period when the civil service was still highly politicized. Politicians complained of interference from those appointed by previous governments, and people publicly still expected to be rewarded for their support with a government position. While overstating the extent of professional disinterest, Kingsford highlighted the emerging shift between politicians and civil servants. As the relationship between the two changed, professional rhetoric became more important. It is also worth noting that Alexander Mackenzie supported Kingsford in his appeal against Langevin, so it is probable the accusations of Tory conspiracies were not substantiated. That false accusations were passed through offices suggests that the civil service was hardly the haven of reason that Kingsford claimed.

Mackenzie's support for Kingsford outlined the changing, and sometimes confused, ideas about public service. In his exchanges with Langevin he brushed aside the notion that the firing was tied to efficiency. According to Langevin, the new arrangement reduced the average costs of surveys, thus increasing the number of surveys that could now be afforded. Mackenzie replied, "the hon. Gentleman talks about the number of surveys, but it entirely depends on what the surveys were. There have been a large number of a very trifling character. The fact remains that the hon. Gentleman dismissed an old and faithful servant." ${ }^{278}$ In challenging Langevin's claims of efficiency, Mackenzie made an appeal to data. He disagreed that the Public Works department was more efficient. He concluded, however, that this was less relevant than how Kingsford

\footnotetext{
${ }^{277}$ This separation of professional workers from politics fit the broader discourses about scientific and engineering work in an age of "mechanical objectivity." Lorraine Daston and Peter Galison, "The Image of Objectivity," Representations, 40, Special Issue (1992), 81-128.

${ }^{278}$ Kingsford, Memoir, 15.
} 
was treated. Again we can see ideals of empiricism coexisted with those of loyalty and service. Mackenzie felt that Kingsford "deserved well of the department," even if, as a Tory appointee, he was "a political opponent of mine." 279 This view was outside the partisanship that normally governed patron-client relations throughout the earlier nineteenth-century. Mackenzie later identified Kingsford as part of a group that performed "good service for their country." 280 In addition to linking Kingsford to nationalist causes, this made an appeal to a public outside the state. The public good was constructed as different than party service. This fits with the somewhat non-partisan view of the civil service. Kingsford's service was not for party or personal gain, but for the good of the country. In defending Kingsford, Mackenzie referred to an authority removed from partisan interest. This frames the civil service differently from the existing patronclient or victor-spoils systems. Nevertheless, it was a view based on a personal characteristic, loyalty, rather than more empirical and objective data. A reformist patron like Mackenzie felt comfortable invoking the very positions he wanted to reform - a personalized understanding of public service - when they could function as effective rhetorical tools.

The approaches Kingsford used to contest his dismissal also reflected the changing understandings of service, loyalty and professionalism. He explained that "as was natural in such circumstances I addressed myself to friends with political influence, and asked their intervention."281 In their study on professional work in nineteenth-century Ontario, Gidney and Millar note that it was common for professional men to help their

\footnotetext{
${ }^{279}$ Ibid., 16.

280 Ibid., 25.

281 Ibid., 25.
} 
younger colleagues. ${ }^{282}$ Regarding patronage, a common example of this was writing recommendations. In a political context, older and well-connected men also often turned to personal connections as their first option. Even though Kingsford was promoter of the type of empiricism that underscored standardization and regulation, he still recognized the importance of something as intangible as friendship in times of crisis. As noted above, Kingsford was concerned with his reputation. He did not want to be a figure of public gossip. Rather, he claimed, he originally understood all this as "a matter of some delicacy," and attempted to keep it relatively private. ${ }^{283}$ In turning to his friends for intervention he attempted to go through informal channels and protect his privacy. The reluctance of making his case a public issue also reflected Kingsford's self-representation as a professional civil servant. Tom Crook has argued that secrecy was an important corollary to transparency in British civil service reform. This movement was one to "secure a class of gentlemen administrators distinguished by their moral character and capacity for corporate self-sacrifice and quiet reserve."284 These men were trusted to know what should be made public and what should not. In attempting to keep his situation private, Kingsford placed himself in this model.

One of the people he turned to was Charles Tupper, then the Conservative Minister of Railways and Canals. Kingsford first approached his deputy minister, although he "did not do so officially but personally, a course often followed in a public department." 285 This fits with Kingsford's original attempt to keep the matter private. It

\footnotetext{
${ }^{282}$ R.D. Gidney and W.P.J. Millar, Professional Gentlemen: The Professions in Nineteenth-Century Ontario (Toronto: University of Toronto Press, 1994), 183.

${ }^{283}$ Kingsford., Memoir, 25.

${ }^{284}$ Tom Crook, "Secrecy and Liberal Modernity in Victorian and Edwardian England," in Gunn and Vernon, eds., The Peculiarities of Liberal Modernity in Imperial Britain, 82.

${ }^{285}$ Kingsford, Memoir, 23.
} 
also shows how personal ties remained important, even as departmental processes were regulated and standardized. His appeal to Tupper further reflected the interaction between personal and professional characteristics. Kingsford hoped that as "a professional man, he would understand the slight put upon me."286 This again highlights Kingsford's concern for his professional and his public reputation. As a doctor and another professional man, it was likely that Tupper would recognize the important interaction of respectability and employment, as well as that of personal and public appearances. Furthermore, Kingsford expressed hope that, since Tupper was "a man of education... he would not commence the administration of his Department by a gratuitous departure from those principles of right and fair dealing." 287

There is of course implicit flattery to Tupper and criticism of Langevin in this statement, and these were indicators of the moralizing and self-aggrandizing elements involved with civil service reforms. Bourgeois, professional men led these reforms. As administration became more standardized and regulated, it was expected to conform to notions of professional respectability. As Philip Corrigan, Harvie Ramsay, and Derek Sayer note, "state-forms are related to the social relations and conditions of specific modes of production in their historical development. ${ }^{, 28}$ In the example of latenineteenth-century Canadian civil service reform, the motivating social relations were those of bourgeois professionalism. As Kingsford flattered Tupper, he also situated himself as part of this professional class that both recognized and set the right way to govern and administer.

\footnotetext{
${ }^{286}$ Ibid., 23.

${ }^{287}$ Ibid.

${ }^{288}$ Philip Corrigan, Harvie Ramsay, and Derek Sayer, "The State as a Relation of Production," in Corrigan, ed., Philip Corrigan, ed. Capitalism, State Formation and Marxist Theory (London: Quartet Books, 1980), 5. Emphasis in original.
} 


\section{The Reluctant Pamphleteer}

Even as Kingsford made personal and private appeals, he still relied on techniques of data collection and publicity. Immediately after his dismissal he wrote a personal letter to John A. Macdonald, not published in the pamphlet, challenging Langevin's claims and anticipating his later decision to go public with "the facts" of his dismissal. "The proper mode of establishing this view," he explained, "is to publish the correspondence and documents bearing upon the case." ${ }^{289}$ Here his reliance on empiricism was linked to the public. He explained that the ideal place to do this would be in a newspaper, arguably the most visible and influential space of the public sphere in the late Victorian era. His correspondence and remarks were too large, however, so he made a pamphlet. As in his pamphlet, however, he also made sure to note that with his letter to Macdonald he enclosed "copies of the complete correspondence between myself and the Hon. Mr. Langevin.",290

Kingsford applied this inventorial approach to specific correspondence as well as to the more general terms of his claims and investigations. To Macdonald he noted and complained that "seventeen days have elapsed and I have received no communication on the subject." ${ }^{291}$ He similarly complained to Langevin that in the six months since he sent a letter, he had not received a response. In outlining these silences, Kingsford showed his tendency to observe as specifically as he could. He was also willing to analyze these

\footnotetext{
${ }^{289}$ LAC, Macdonald Fonds, vol. 310, William Kingsford to John A. Macdonald, December 11880 , 140994.

${ }^{290}$ Ibid., 140993.

${ }^{291}$ Ibid., 140994.
} 
observations. To Kingsford, the silence from Langevin confirmed that "it is not the intention of the Government to give me professional employment."292

Part of the process of writing privately was to suggest that he was willing to make the matter more public. When writing to Macdonald he explained that one of the reasons he was keeping the Prime Minister abreast of his situation was "in the case of my being forced to appeal to...the House of Commons, you will not be without knowledge of the circumstance under which that appeal will be made."293 This statement served a myriad of rhetorical and strategic functions. In providing information to Macdonald, it paid him the deference he would likely have expected as the top patron in the Canadian system. It also served to further catalogue Kingsford's motivations and evidence. In writing to Macdonald, he was being transparent about his goals and his interests. Despite being respectful and clear to Macdonald, there was also an ultimatum in this statement. Should he not be satisfied with this treatment through personal channels, Kingsford claimed he would go through more formal means. Shortly after this letter, he wrote again, this time expressing his frustrations and intentions more strongly. Still not receiving responses from Langevin, he stated: "I am forced to the consideration that it is idle to expect justice at the hands of the Minister of Public Works and that there is no alternative course but to appeal to the people of Canada, through their representatives in the House of Commons, for justice against the persistent wrong I am experiencing." ${ }^{294}$ Kingsford again emphasized his reluctance to go public. In expressing that he was "forced," Kingsford underscored that this avenue was a last resort. This statement also highlighted the

\footnotetext{
${ }^{292}$ Kingsford to Langevin, 20 August 1880, in Kingsford, Memoir, 32.

${ }^{293}$ LAC, Macdonald Fonds, vol. 310, William Kingsford to John A. Macdonald, 10 November 1880, 140976.

${ }^{294}$ LAC, Macdonald Fonds, vol. 310, William Kingsford to John A. Macdonald, December 91880 , 140998.
} 
changing understanding of the civil service. Kingsford's personal issue was to be placed before the people of Canada. In doing this he challenged the privilege of ministers to manage the civil service to their own means.

Having issues of employment, dismissal, and government recompense made public was a concern for the government in this period. A "private and confidential" letter to J.S. McCuaig brought up the case of a lighthouse keeper who was fired, but still owed fifty dollars. Even though this was a much smaller sum than that sought by Kingsford, the letter still stated that such charges "would have a tendency, if made public, to bring the Gov into disrepute. ${ }^{, 295}$ Here public reputation is a concern, but for the whole government. This was related to the shifting importance of patron-client relationships in the period. As politicians attempted to keep control of the civil service, one of the key aspects was keeping the loyalty of the civil servants. The publicity brought on by not paying an employee what he was owed would have hurt this position.

Bringing public attention to a case was not guaranteed to bring about government action. Kingsford was never paid the money he felt he was owed. In fact, it sometimes had long-lasting repercussions for the claimant. For Kingsford, for example, the federal government apparently did not officially buy any copies of his History of Canada. ${ }^{296}$ But it is the example of D.B. Skelly that illuminates some of the potential professional harm that came from making a public case against unfavourable civil service appointments.

Skelly wrote a number of letters to Macdonald unsuccessfully asking for interventions and appointments between 1872 and 1890. He was an engineer and Conservative partisan from Hamilton and after contributing his own money to an 1872

\footnotetext{
${ }^{295}$ LAC, Macdonald Fonds, vol. 307, E.B. White to J.S. McCuaig, November 3 1879, 139931.

${ }^{296}$ Shannon, "A Canadian Historian," 194. The government of Ontario, under Oliver Mowatt did buy 100 copies, though.
} 
campaign he expected an appointment from Macdonald. The positions he was offered were not to his liking. He wanted a supervisory position, but was instead expected "to take off my coat and work" on a railway. He was also offered a job as an engineer in Red River, but that only paid fifty dollars a month, which he took as an "insult." 297 This is indicative of the complexities of patron-client relationships. These were ongoing negotiations that intersected with ideas about service, loyalty and respectability. Skelly, who saw and presented himself as a professional, wanted a job with more prestige, reward, and luxury than he was offered. Kingsford wrote about professionalism in terms of education, reason, and judgment. Skelly brought another performative element of this professionalism - dress. In resisting removing his coat, Skelly was aware that the body was where constructions about respectable masculinity were made visible. Not coincidentally, as the civil service was reformed in the late nineteenth century the body, too, became increasingly regulated, an issue explored in more detail in Chapter Six.

To request better positions, and eventually to ask for compensation for the money he spent on the election, Skelly took a similar approach to Kingsford. He wrote to Macdonald asking for "favor by a private letter." ${ }^{, 298}$ Here he was relying on friendship and personal connections to sort out his position. He explained that he could "if asked get up a petition... signed by the best men in the city, but sir I do not wish to do it a present." Seeking public support was a common tactic to secure a patronage appointment, but

\footnotetext{
${ }^{297}$ LAC, Macdonald Fonds, vol. 302, D.B. Skelly to Macdonald, 16 June 1873, 137953. Ideas about respectability, dress and work were a recurring theme in Skelly's life. In 1879 he was an engineer in the Hamilton fire department. He was thrown into a gutter and charged for insubordination by Alexander William Aitcheson, the reform-minded chief, for not wanting to wear the departmental uniform. Skelly argued, unsuccessfully, that his skill as an engineer distinguished him from the others and he should not be expected to dress like them. David G. Burley, "Aitcheson, Alexander William" in Dictionary of Canadian Biography, http://www.biographi.ca/009004-119.01-e.php?\&id nbr=6520, last accessed 2 July 2013. ${ }^{298}$ LAC, Macdonald Fonds, vol. 302 D.B. Skelly to T. Ferguson, Macdonald, February 7 1872, 137906.
} 
Skelly preferred the issue "be only known to you [Macdonald] and myself." 299 The relationship between liberal independence, respectability, and patronage was complex. Like Kingsford's memoir, Skelly was expressing a private interest in a public appointment. Unlike Kingsford, however, he sought to keep the matter between himself and his Tory patrons. The situation was somewhat different, since Kingsford was dismissed while Skelly was seeking a post, but both writers were expressing concerns about their reputations. For Skelly, while asking for help it was important to keep the appearance of his independence.

Skelly did eventually make parts of his correspondence public when he took his case before the Minister of Justice. In an 1880 letter to Macdonald, marked "strictly private," he claimed it would be the last correspondence on the subject. Skelly explained that Macdonald would only hear of his case "from public quarters, I am sick and tired begging my own from you. I don't want one cent from you but what is honestly due me and that Sir I think you cannot blame me for trying to get as best I can." ${ }^{, 300}$ This approach did not pan out. His letters were passed back and forth between assistants, but his case was never heard and an appointment never came. In 1890, after years of frustrations and misfortune he was informed that the reason Macdonald "failed to make your words good in my case is due to the fact that I made public some of your private letters." ${ }^{301} \mathrm{In}$ reference to this, Skelly wrote Macdonald a long and impassioned letter, which will be explored in more depth in Chapter Seven. What is relevant here is that it highlights the awkward positioning of appointments between public and private for both politicians and

\footnotetext{
${ }^{299}$ LAC, Macdonald Fonds, vol. 302, D.B. Skelly to Macdonald, January 101872,137901

${ }^{300}$ LAC, Macdonald Fonds, vol. 364, D.B. Skelly to Macdonald, January 12 1880, 168604.

${ }^{301}$ LAC, Macdonald Fonds, vol. 489 D.B. Skelly to Macdonald, October 13 1890, 244622. Interestingly, Skelly also points out that he only made Macdonald's letters public after Macdonald had done the same to him This is taken up in more detail in Chapter Seven.
} 
applicants. Resulting from the emphasis on respectability and independence, these positions continued to be based on personal characteristics. This personal aspect meant that private circumstances were considered in the process. But these were also public positions, and public attention was sometimes brought to these matters.

The cases of Kingsford and Skelly are instructive about the flexibility and persistence of patronage even as reform ideas took hold. This highlights the Foucauldian point that the state is a set of practices, "a way of governing, a way of doing things and a way too of relating to government. ${ }^{302}$ Kingsford and Skelly both demonstrated a way of relating to politicians and administrators that drew from modernizing, democratic rhetorics and from patron-client rhetorics. They focused both on professionalism and on loyalty, on qualification and on friendship. These two cases further show the changing conceptions of the civil service. Although still under the influence of politicians, administrators were beginning to make appeals to different types of authority. At times this authority was based on professional credentials. In other instances, Kingsford and Skelly appealed to public opinion. That both were reluctant to make their cases public also suggests that this transition was uneven. Personal connections and characteristics were important even in a period of reform. To be a good public servant was to navigate this relationship successfully.

The attempts to maneuver between public and private are also reminders that processes of state formation were sometimes enacted at an individual level. Kingsford attempted to participate in the political culture through both private and public channels.

\footnotetext{
${ }^{302}$ Michel Foucault, Security, Territory, Population: Lectures at the Collège de France, 1977-1978, Michel Senellart, ed., Translated by Graham Burchell (New York: Palgrave Macmillan, 2004), 277.
} 
Although these are general categories, when looked at an individual level, they highlighted the different ways people wrote about public work. Kingsford's appeal was personal and, at times, private. When he did not get the results he desired he turned to the authority of public opinion. As he did this he also presented himself as representing the imagined ideal public servant - one who was motivated by professionalism, nonpartisanship, and empiricism. ${ }^{303}$ In turning to public opinion Kingsford differentiated between public and party interests. The rhetorical basis for his claims that he was unjustly dismissed lay in the fact that considered himself to be a good public servant. In contrast, Langevin was motivated by partisanship, rather than a sense of the public good. While still deferring to political elites, Kingsford relied on a political and moral authority outside the state and partisan interests.

The changing basis of authority is also demonstrative of how government administrators moved between public and private worlds. Appointments were based on private characteristics and still to a degree on personal connections. At the same time, Kingsford appealed to public discourse to support his claim. The civil service commission of 1880-1881 attempted to make the internal workings of the civil service more widely known and registered. The next chapter will explore how these efforts were made more precise and explicit in the 1891-92 commission.

\footnotetext{
${ }^{303}$ Robert Lanning notes that a similar tactic was biographical dictionaries, where entries were deliberately selected for their "representativeness," which "was established as a public identity; that is, to the extent that individual lives could be seen or claimed to be parallel to the life of the nation, in terms of progress and the development of character and of purpose." Lanning, The National Album, 69.
} 


\section{Chapter 4}

\section{'An immense waste of power:' The 1891-92 Royal Commission and the Civil Service's Regulation and Management}

The panic spreads in the civil service. Day after day the grossest irregularities are exposed in the departments. Day after day wholesale jobbery and rascality are exposed before the Committee on Privileges and Elections. ${ }^{304}$

The Globe, 1891

The Board has now been organized over ten years, and therefore had large opportunities of gaining experience in regard to the best modes of examination and the requirements of the service. They have discharged their tasks to the best of their ability, and have reason to believe that their work has been satisfactory, since it has operated to preclude any but worthy and fairly capable persons from obtaining employment in the Civil Service. ${ }^{305}$

Report of the Board of Civil Service Examiners, 1893

By the 1890s, debates about the civil service were less on the nature of the work and positions, and more focused on every day regulation and practices. Since the civil service was more organized, debates about competitive examinations, efficiency, economy, and professionalism were more integrated than they had been. As the previous two chapters argued, the civil service reforms of 1882 did not eliminate patronage or partisanship in Canada's civil service. It became more heavily monitored and the appointment process more heavily regulated, but political influence remained an important reality for the federal bureaucracy. A variety of criticisms and suggestions were levied at the civil service throughout the 1880s. The frequent amendments reflected that administrative ideas and the relationship between politicians and administrators were evolving, or at the very least perceived to be doing so.

As these multiple positions continued to be staked and navigated throughout the 1880s, the Civil Service Act continued to be debated and amended. It was brought before

\footnotetext{
304 The Globe, 15 July 1891, 24.

${ }^{305}$ Canada, Parliament, Sessional Papers of the Dominion of Canada, Vol. 9, $7^{\text {th }}$ Parliament, $3^{\text {rd }}$ Session, (Ottawa: S.E. Dawson, 1893), 16B-8.
} 
the House so frequently that Peter Mitchell, an independent Member of Parliament (hereafter MP) from Northumberland, suggested that "in place of getting legislation from year to year in amendment of the Civil Service Act, which in my opinion and the opinion of others should never have been brought into existence, the Government should repeal the Act; it would be the most popular thing that they have done for a long time."306 Mitchell's proposal showed the frustrations with the reforms' inability to meet the expectations of reformers. The frequent amendments to the act also reflected, however, the procedural nature of state formation. The Civil Service Act of 1882 was not an endpoint, but rather one instance in the continuous processes of definition, expansion, and rationalization of the Canadian state.

These ongoing debates and amendments led to the creation of a second Royal Commission on the Civil Service, in 1891-92, and to amendments to the Civil Service Act in $1895 .^{307}$ This remains an understudied period in Canadian administrative history. In J.E. Hodgetts' pioneering work, The Canadian Public Service, there is no mention of the 1895 amendments. The $1891-92$ commission is similarly underrepresented. Hodgetts uses the nineteenth-century civil service commissions as sources on departmental organization, but he does not analyze their logics. In Hodgetts' index, the Royal Commission of 1892 only has four instances; these are largely used as sources to identify organizational features that continued into the twentieth century. ${ }^{308}$ This lack of emphasis

\footnotetext{
${ }^{306}$ Canada, Parliament, Debates of the House of Commons, $5^{\text {th }}$ Parliament, $3^{\text {rd }}$ Session, (Ottawa: Maclean Roger, 1885), 1097-1098.

${ }^{307}$ Canada, Parliament, "An Act Respecting the Civil Service of Canada" Sessional Papers of the Dominion of Canada, Vol. 10, $7^{\text {th }}$ Parliament, $5^{\text {th }}$ Session (Ottawa: S.E. Dawson, 1895), 16A-181.

308 J.E. Hodgetts, The Canadian Public Service: A Physiology of Government (Toronto: University of Toronto Press, 1973), 266. Similarly, Gordon T. Stewart highlighted how until 1914 patronage was used to maintain political and regional stability. The Origins of Canadian Politics: A Comparative Approach (UBC Press, 1986), 87, 99.
} 
is likely because patronage continued to be prominent into the twentieth century. ${ }^{309}$ This narrative, however, does not do justice to the complex processes of state formation that underscored reform. The continuous nature of civil service reform was noted by the 1892 Report from the Civil Service Commissioners: "This Act [Civil Service Act of 1882], although not going so far in its provisions as was recommended by the Commission, has been amended year by year, with one exception, from the time of its being first placed on the Statute book until the year $1889 .{ }^{310}$ In this instance, the commissioners underscored that the 1882 Act implemented an entrance examination for the civil service, rather than the competitive examination as recommended by the commissioners and also used in England.

This chapter explores the continuing criticisms and suggestions levied at the civil service, especially those collected in the 1892 Civil Service Commissioners' Report. As in the lead-up to 1882 , these criticisms take aim at the continued partisanship and favoritism in the civil service - against "the shabbiest and meanest boodling yet revealed... in connection with the sale of Government offices." ${ }^{311}$ Again, the responsibilities and expectations of what a civil servant should do and how they should be evaluated were debated. The main sources used here - Sessional Papers, Hansards, and newspapers - reflect a shared public rhetoric of politics and of reform. In these sources, we can see administrators and politicians making public statements about administrative practices. These statements point to the civil service's ongoing re-

\footnotetext{
${ }^{309}$ Bill Doherty, Slaves of the Lamp: A History of the Federal Civil Service Organizations, 1865-1924 (Victoria, BC: Orca Books Publishers, 1991), 17; Ken Rasmussen, "Administrative Reform and the Quest for Bureaucratic Autonomy: 1867-1918," Journal of Canadian Studies 29:3 (1994): 45-62; David E. Smith, "Patronage in Britain and Canada: An Historical Perspective," Journal of Canadian Studies, 22:2 (1987), 34-54.

310 Canada, Parliament, Sessional Papers of the Dominion of Canada, vol. 11, $7^{\text {th }}$ Parliament, $2^{\text {nd }}$ Session (Ottawa: S.E. Dawson, 1892), 16C-xviii.

${ }^{311}$ The Globe, 5 September 1891, 12.
} 
imagining in the late-nineteenth century. This rhetoric shows debates over the best methods to achieve reform and the best way to evaluate candidates. It also demonstrates politicians' and administrators' self-conscious reliance on transnational ideas of selfgovernment, supervision and record keeping. And, as in the preceding chapters, both Conservatives and Liberals again attempted to make this a partisan issue, contrasting the other side's corruption with their own reforming initiatives.

The key difference between the reforms of 1882 and those of 1892 was the specificity and precision of the commissioners' report. The main thrust of the 1882 report was fairly simple: "the Commissioners recommended to adoption of the essential principles of open competitive examination and promotion by merit as an effectual remedy for all the important defects of the system then in vogue. ${ }^{„ 312}$ It set out the basic organization and supervision of Canadian bureaucracy. As we will see, the suggestions made in 1892 were more far-reaching. The everyday management of the civil service became the commissioners' goal. It was no longer enough to limit partisanship in the appointment process; rather, the 1892 report aimed to governmentalize the civil service to standardize everyday practices, to promote efficiency, and to regulate personal conduct. These changes were technical and have generally been ignored. As Nikolas Rose reminds us, however, "it is, most often, at this vulgar, pragmatic, quotidian, and minor level that one can see the languages and techniques being invented that will reshape understandings of the subjects and objects of government, and hence reshape the very presuppositions upon which government rests. ${ }^{.313}$ These changes were situated in a context of reform and professionalization, and they were promoted with a rhetoric of

\footnotetext{
${ }^{312}$ Parliament, Sessional Papers, 1892, 16C-xvii.

${ }^{313}$ Nikolas Rose, Powers of Freedom: Reframing Political Thought (Cambridge: Cambridge University Press, 1999), 31.
} 
democratization. This rhetoric, and the specificity that accompanied it, was enabled by the reforms of 1882. As such, we need to think of 1892 as part of the longer, messier, and oftentimes fragmentary processes of state formation.

\section{The Civil Service Commissioners}

The civil service commissioners were George Hague, George Wheelock Burbidge, Edmond Barbeau, and John Mortimer Courtney. There was little commentary about the commissioners' political affiliations, but they did have links to the Conservative party. Courtney was born in England and had worked in India and Australia before joining the Canadian Treasury in 1869 . This position was a Tory appointment and he worked with Samuel Leonard Tilley, the Minister of Finance, to prepare the National Policy budget. ${ }^{314}$ Burbidge, from New Brunswick, was the lawyer that assembled the Crown's case against Louis Riel in $1885 .{ }^{315}$ Hague and Barbeau were both prominent Montreal bankers. Hague, who was the commission's chairman, was the general manager of the Merchant's Bank in Montreal. This bank worked with the Tory government in the 1860s to resolve a banking credit crisis. ${ }^{316}$ These appointments reflected the balance between partisanship and professionalism. It is somewhat ironic, if not surprising, that those appointed to reform the civil service had party affiliations. That these party affiliations were not widely broadcast suggests that the commissioners were presented

\footnotetext{
${ }^{314}$ John A. Turley-Ewart, "Courtney, John Mortimer," Dictionary of Canadian Biography Online, http://www.biographi.ca/009004-119.01-e.php?\&id_nbr=7299, last accessed 3 July , 2013. Turley-Ewart notes that Courtney had "liberal leanings" since he was "sympathetic to the Liberal attack on patronage."

${ }^{315}$ Desmond H. Brown, "Burbidge, George Wheelock" Dictionary of Canadian Biography Online, http://www.biographi.ca/009004-119.01-e.php?id_nbr=6593, last accessed 2 July 2013.

${ }^{316}$ This resulted, in part, from the Provincial Notes Act of 1866 . This act, written by Tory Alexander Tilloch Galt, limited the rights of banks to print their own notes, replacing them with government notes. The Bank of Montreal was the only financial institution to accept the law. Ronald Rudin, "King, Henry Edwin' Dictionary of Canadian Biography Online, http://www.biographi.ca/009004-119.01e.php?\&id_nbr=6197, last accessed 3 July 2013. Edmond Barbeau had been the manager for the Montreal City and District Savings Bank. John Irwin Cooper, "The Origins and Early History of the Montreal City and District Bank, CCHA Report, 13 (1945-46), 15-25.
} 
objective and non-partisan - the same class of public men of affairs with whom William Kingsford was aligned.

Hague's appointment, according to The Globe, gave "general satisfaction."317 Given the emphasis on applying business methods to the civil service, Hague's background was not surprising. The focus on business rather than politics was reiterated when asked if the commissioners would inquire into the scandals over corruption and patronage throughout the 1880s. The Globe quoted Hague as explaining that "there will be no inquiry into scandals. The object is simply to place the civil service on a business footing. There is nothing political in the inquiry at all."318 This highlighted the process of professionalization that was at the commission's centre. It sought to replace political concerns and influences with those based on business principles. This practical focus likely also reflected the partisan concern that the Conservative government would not want a commission it appointed to inquire further into its corruption scandals. ${ }^{319}$

The commissioners were self-consciously transnational in their outlook. They continued to draw inspiration and warnings from the European, Indian, and American examples. The U.S. in particular was treated differently than it had been in the debates leading to the 1882 report. Politicians still tended to draw on anti-American rhetoric, but both the commissioners and the administrators they interviewed espoused a more nuanced view. Several department heads acknowledged that the American civil service

\footnotetext{
317 The Globe, "The Civil Service Commission," 15 October 1891, 5.

318 Ibid.

319 The Langevin-McGreevy scandal, where Thomas McGreevy accepted kickbacks to grant public works contracts, under Langevin's supervision, was likely the issue they had in mind. Douglas Owram, Building For Canadians: A History of the Department of Public Works, 1840-1960 (Public Relations and Information Services, Public Works Canada, 1979), 161-162.
} 
had adopted a competitive examination, and it had been somewhat successful. ${ }^{320}$

Commissioner George Hague closed the report by explaining in preparation for his duties he visited Washington, to study the workings of the American civil service. He explained that he was particularly interested in exploring the open, competitive appointment process. This system, he reported, "has worked admirably, and is carried out in a most business-like and efficient manner." ${ }^{321}$ He recommended this example to the Board of Civil Service Commissioners. To Hague part of the appeal of the new American system was that it was 'business-like' and 'efficient.' He included a letter from the United States' Postmaster General, J.N.O. Wanamaker, which elaborated on this theme, explaining that open competition helped "keep out laziness, loafing, and inefficiency." Applying competition to promotions was also an improving measure, since it ensured "that the competent and able men will get on and the other men be left behind." 322

The United States serving as a model for successful bureaucracy points to a shifting transatlantic world. As Daniel Rodgers notes in Atlantic Crossings, the latenineteenth century saw a shift in America's view of the Europe. Up to that point, Americans tended to portray Europe as "the Old World: the continent of decadence and decay," while the America was "new: the continent of rebirth, a site of new historical dispensation." 323 The realignment of the late-nineteenth century, however, repositioned

\footnotetext{
${ }^{320}$ Parliament, Sessional Papers, 1892, 16C-xxiii. Goldwin Smith praised President Cleveland for "so nobly and bravely struggling to rescue the American Republic," from a rotating, partisan civil service. Goldwin Smith, "The Political History of Canada," The Nineteenth Century and After: A Monthly Review (July, 1886), 14

${ }^{321}$ Parliament, Sessional Papers, 1892, 16C-xciii.

${ }^{322}$ Ibid., 16C-xciv.

${ }^{323}$ Daniel T. Rodgers, Atlantic Crossings: Social Politics in a Progressive Age (Cambridge, Mass: The Belknap Press of Harvard University, 1998), 34. Rodgers defined period from 1870-1945 as "the Atlantic era in social politics." This was an era where economic and social ideas reached "from Berlin to San Francisco" (4).
} 
Europe as the "base of culture, custom and time" to American thinkers. ${ }^{324}$ Canadian thinkers and planners are absent from Rodgers' discussion of the North Atlantic economy of ideas. The debates over civil service reforms, however, show that Canadian reformers were engaged in this transatlantic world. The shift in Canadian thought and rhetoric was significantly different from that of Americans, however. Previously in the century, Canadians presented England as the beacon of progress and America as the nadir of corrupt practices. By the 1890 s the rhetoric of Canadian bureaucrats was more nuanced regarding American practices. Administrators were able to compare and contrast the Canadian example with both American and British (and to a lesser extent other European and colonial) practices. This example somewhat complicates the relationship between Canadians and American thought, presented by Damien-Claude Bélanger. He suggests that in late-nineteenth-century Canada the U.S. was linked to modernity. Canadian thinkers struggled with "different understandings of Canada, one of which was fundamentally anti-modern. ${ }^{, 325}$ Linking American reforms with modernity fits with how civil service reformers now thought of the U.S. These reformers did not, however, have the same anti-modern qualms as the personalities in Bélanger's study.

In their report, the commissioners explained that they understood the purpose of reforms as "remedying the evils which have prevailed" and "increasing the efficiency and economy of the service. ${ }^{326}$ Much as in 1882, this meant replacing patronage with business methods, but the commission was even more precise in its goals. The commissioners explained their recommendations were "to suggest such improvements in

\footnotetext{
${ }^{324}$ Ibid., 39.

325 Damien-Claude Bélanger, Prejudice and Pride: Canadian Intellectuals Confront the United States, 1891-1945 (Toronto: University of Toronto Press, 2011), 7.

${ }^{326}$ Parliament, Sessional Papers, 1892, 16C-x.
} 
methods applicable to all departments as will tend to prevent irregularities in future."327 This rhetoric was fairly general, but the goal precise: to develop standard practices for the civil service.

To enable their inquiry the commissioners' prepared a series of questionnaires for different members of the inside service. They asked permanent employees about appointments, promotion, discipline, duties, salaries, and superannuation. Temporary clerks were asked the same questions, except for those pertaining to superannuation. On departmental levels, they examined present organization, efficiency and sufficiency of staff, the supervision of the financial business of the departments, the system of purchase, and the performance of extra work. The questionnaire also asked respondents to comment on "any other subject connected with the Civil Service which, in the opinion of the Commissioners, requires consideration and readjustment in order to attain the greatest possible efficiency." ${ }^{, 32}$ They followed the questionnaires with interviews with deputy heads and departmental representatives. The commission cast a wide net so as to gather as much information as possible.

Using questionnaires rather than interviews reflected two of the commissioners' methodical concerns. They explained that "this method of procedure had the effect, it is believed, of obtaining accuracy of information in matters of detail, and also of shortening to some extent the time occupied in the enquiry." ${ }^{329}$ In-and-of itself this view demonstrated ideas about a statistical and scientific mode of enquiry. This mode was dominant in social and political thinking in the Victorian era. In an essay on nineteenthcentury liberalism, security and public sanitation, Thomas Osborne writes that

\footnotetext{
${ }^{327}$ Ibid., 16C-xii.

${ }^{328}$ Ibid. The outside service was once again left largely to its own initiatives.

${ }^{329}$ Parliament, Sessional Papers, 1892, 16C-xiii.
} 
"[e]verything was to be administered: roads, canals, morals, health, commodities....

Nothing was to be impervious to the gaze of knowledge; the exercise of government demanded a thoroughgoing instrumental command of the domain to be governed." 330

Knowledge mediated the relationship between the state and authority. By supporting their positions with empirical data, administrators could strengthen their claims. As Theodore Porter argues, scientific investigation and data are forms of communication. By presenting data as objective and complete, they help secure the authority of the investigators. ${ }^{331}$ Mark Neocleous makes a similar point in Imagining the State. He refers to statistics as a technique of government, whereby the process of information-gathering is turned into official state knowledge. ${ }^{332}$ By gathering as much information as possible, the commissioners presented their report as being authoritative knowledge. It was more valuable because it was vast and empirically complete. This highlights how the process of governmentalization operates at all levels in the civil service. By referencing empiricism, the commissioners were able to highlight their rationality, and their subsequent position to govern the conduct of those below them in the administration. The commissioners wanted empirical data, but they also wanted to be fast and inexpensive. In other words, even in their methods they promoted efficiency and economy. Following their recommendations, the commissioners appended the responses as evidence to their report, giving their suggestions an empirical and thus factual basis.

\footnotetext{
${ }^{330}$ Thomas Osborne, "Security and Vitality: Drains, Liberalism and Power in the Nineteenth Century" in Andrew Barry, Thomas Osborne, Nikolas Rose, eds., Foucault and Political Reason: Liberalism, NeoLiberalism, and Rationalities of Government (Chicago: University of Chicago Press, 1996), 100. Bruce Curtis, "The Canada 'Blue Books' and the Administrative Capacity of the Canadian State, 1822-1867," Canadian Historical Review, 74:4 (1993), 535-565; Bruce Curtis, "On the Local Construction of Statistical Knowledge: Making Up the Census of the Canadas," Journal of Historical Sociology, 7:4 (1994), 416-434.

${ }^{331}$ Theodore M. Porter, Trust in Numbers: The Pursuit of Objectivity in Science and Public Life (Princeton: Princeton University Press, 1995), viii.

${ }^{332}$ Mark Neocleous, Imagining the State, (Maidenhead: Open University Press, 2003), 54. Neocleous draws heavily from Ian Hacking's The Taming of Chance (Cambridge: Cambridge University Press, 1990).
} 
The commissioners furthered their investigation by making a public call for any person who desired to make a statement about the civil service. They could comment on whether "any abuse or irregularity existed, or wherein any step might be suggested or taken to increase the efficiency and economy of the service." 333 The Commission's Secretary would record their names, and they could put their name forward to be a witness before the Commission. This fit with the Commission's attempts to gather as much information as possible. It also legitimized the investigation by buttressing it with democratic rhetoric. As we will see, reforms were promoted in terms of justice and equality. Open competition would give those without political connections a chance at appointment. The commissioners' investigation likewise followed this trend. In asking for public contributions they gave citizens a chance to express their ideas and opinions on the civil service. The irony of this is that the appeal to the public secured the authority of the small group of commissioners. Those who responded to this call to the public would likely have been from the same class as those who desired positions, generally middleclass men, or those from the upper classes who had interests in local administration. Processes of state formation rely on creating collective representations. Although totalizing, the conditions on these representations are generally limited and exclusionary. ${ }^{334}$ The report on the civil service was given heft because it was positioned as being democratic, even if this served to reinforce the dominant assumptions about civil servants.

\footnotetext{
333 Parliament, Sessional Papers, 16C-1892, xiv.

${ }^{334}$ Philip Corrigan and Derek Sayer, The Great Arch: English State Formation as Cultural Revolution (Oxford: Basil Blackwell, 1985), 6.
} 


\section{Continuing Criticisms}

The commissioner's report to Parliament gave credit to the Civil Service Act of 1882 for beginning the process of reform. And by the close of the 1880 s, the Canadian civil service had undergone significant transformations. The Civil Service Act of 1882 gave a sprawling and poorly defined administrative body some coherent shape. Contemporary observers described the bureaucracy as an "organised system," that enforced age limits, and regulated appointments and promotions. ${ }^{335}$ According to The Globe, the Act's "main point of excellence" was instituting an entrance exam as a requirement for appointment. ${ }^{336}$

Despite these changes, however, The Globe also reported that the civil service was "not yet free of recognised defects." ${ }^{, 337}$ Patronage continued, unsuitable applicants were still sometimes appointed, and departments had grown out of proportion to the amount of work. Adding to this, "many of the rules laid down in the existing Statutes have been found inconvenient and more or less impracticable, and consequently irregularities have occurred in carrying them out." 338 In his interview with the commission, J.L. McDougall, the Auditor General, explained what he understood to be the defect in the Canadian system. Improvement was hampered, he suggested, by "the continuance of the notion that the management of the public business is the management of what belongs to the Government of the day and not to all the tax payers of the country. ${ }^{339}$ Here he highlighted the ongoing lack of separation between party politics and the civil service, suggesting that politicians continue to see appointive positions as

\footnotetext{
${ }^{335}$ The Globe, 22 February 1889, 3.

${ }^{336}$ Ibid.

${ }^{337}$ Ibid.

${ }^{338}$ Parliament, Sessional Papers, 1892, 16C-ix.

${ }^{339}$ Ibid., 16C-22.
} 
serving their interests, rather than those of the contributing citizenry. ${ }^{340}$ This also reflected a more nuanced understanding of the relationship between governed and governors. Previously, this relationship had been referred to in terms of expectation, reward, and loyalty. The introduction of taxes was a more precise marker of to whom the government was held responsible. This was part of the emergence of a new way to speak about citizenship. Arguably, the biggest piece of legislation in this process was the Franchise Act of 1885, which granted political citizenship to property-owning or renting men who were British subjects. ${ }^{341}$

A secretary in the Post Office, C. Falconer, also stressed the changing relationship between administration and government. He explained that since appointments were considered "a sort or reward for political services rendered, it is more difficult in the Civil Service than in other spheres of labour to bring to bear upon those employed the pressure necessary for securing efficient service."342 Falconer touched upon two frequently used reforming tropes: efficiency and comparisons between the civil service and the private sector. As long as patronage continued, the logic went, the most self-motivated and disciplined employees would enter the private sphere. Those entering in the civil service would focus on gaining favor with patrons, rather than performing their duties.

\footnotetext{
340 The term 'contributing citizens' is drawn from Shirley Tillotson's, Contributing Citizens: Modern Charitable Fundraising and the Making of the Welfare State, 1920-66 (Vancouver: UBC Press, 2008).

${ }^{341}$ As Adele Perry argues, the expansion of this liberal political system was highly connected to the expansion of colonialism and patriarchy. Adele Perry, "Women, Racialized People, and the Making of the Liberal Order in Northern North America," in Jean-François Constant and Michel Ducharme, eds., Liberalism and Hegemony: Debating the Canadian Liberal Revolution (Toronto: University of Toronto Press, 2009), 276. For a detailed examination of the politics of the franchise see Veronica Strong-Boag "The Citizenship Debates: The 1885 Franchise Act," in Robert Adamoski, Dorothy E. Chunn, and Robert Menzies, eds., Contesting Canadian Citizenship: Historical Readings (Peterborough: Broadview Press, 2002), 69-95; Colin J. Grittner, “A statesmanlike measure with a partisan tail:” The Development of the Nineteenth-Century Dominion Electoral Franchise, M.A. Thesis, (Ottawa: Carleton University, 2009). ${ }^{342}$ Parliament, Sessional Papers, 1892, 16C-412.
} 
McDougall further attributed patronage's ability to survive both to politicians' ambition and to demand from party faithful. He explained that the pressure from a politician's supporters was "the result of sentiment and sympathy if not selfishness, and is strong in proportion as the object of the solicitation of the politicians is weak... and the member of the Government wishes to please the man whose vote counts in keeping in power a ministry or in supplanting it. ${ }^{״ 43}$ As we saw in Chapter Two, voters expected patronage, and politicians relied on it to garner support. Even with increasing civil service regulations this remained the case. An 1888 letter to John A. Macdonald, for example, hoped that as the MP for Kingston Macdonald would "have once more the direct interest officially with your old friends here - more particularly with those in the civil service who are of your own choice and make. ${ }^{344}$

McDougall's description of the patronage's mediating role in the relationship between politicians and supporters told a familiar story. He did, however, reflect a shift in rhetoric and outlook from those previously described. Rather than treating this system as business-as-usual, he adopted a reforming view, describing patronage as politically toxic. The danger came from the fact that there were generally more supporters than positions to be awarded. Relying on promises of patronage to secure support might often lead to disappointment. "At best," McDougall explained, "several ardent supporters are rendered lukewarm ones if not opponents." It was not worth risking offending those who were passed over, since whomever was appointed "cannot be turned into two and may even be

\footnotetext{
${ }^{343}$ Parliament, Sessional Papers, 1892, 16C-22. As we will see in Chapter Seven relationships based on sentiments were an important part of the negotiations between patrons and would-be clients throughout the second-half of the nineteenth century.

${ }^{344}$ Library and Archives Canada (hereafter LAC), Sir John A. Macdonald Fonds, MG26-A, vol. 328, J. Murphy to Macdonald, 4 January 1888, 148425.
} 
annoyed that he was not thought worthy of a better position. ${ }^{\text {} 345}$ Interestingly this was a political strategy in favour of professionalization. Although politics and administration were still connected, political strategists began to address them differently.

Falconer made a similar point about patronage negatively affecting relationships, but from the vantage of the civil service's responsibilities. Again pointing to efficiency, self-discipline, and perceived quality of work, he worried that resulting from patronage the "cultivation of political favour thus becomes a matter of more importance than the increase of zeal and efficiency." Like McDougall he related to the personal relationship between patrons and clients, politicians and supporters: "to stand well with friends possessing political influence is of more value to an average civil servant than to stand well with his official superiors. ${ }^{346}$ The Chairman of the Board of Civil Service Examiners, John Thorburn, made this just as explicit in his interview with commission. He noted, "[a]ppointments, when made on political grounds, almost necessarily tend to lower the public service, to degrade the electorate and to bring discredit upon the management of the affairs of the country." ${ }^{347}$ This points to an understanding of patronage as a political tool, connecting politicians and the electorate, as well as managers and the managed. This is a shift from the promise of 'to the victors go the spoils.' In this example, patronage is noted as a political hindrance. Thorburn also highlighted the complicated balance between reform and patronage that politicians navigated. He stated that MPs sometimes complained "of the worry and annoyance to which they are subjected, and the great sacrifice of time and patience they have to submit to in foraging for positions in the departments for supporters whose claims it is not

\footnotetext{
${ }^{345}$ Parliament, Sessional Papers, 1892, 16C-22.

${ }^{346}$ Ibid., 16C-412.

${ }^{347}$ Ibid., 16C-557.
} 
always safe to ignore." While being annoyed by this demand, however, they also recognized that "when every vote counts, promises are made." ${ }^{348}$ As we have seen, this balance frequently led to politicians relying on contradictory rhetorics and positions on patronage.

Part of eliminating patronage was making civil servants responsible to their supervisors, rather than the politicians who secured their appointment. In their interviews, both Falconer and McDougall pointed to the need for an outside body, a permanent Civil Service Commission, to regulate appointments, with an end goal of decreasing patronage. A permanent body was required because it was unlikely that "the possessors of political patronage are prepared to part with what seems to them an element of power to be used for the furtherance of their own ends. ${ }^{, 349}$ Falconer concluded that even if the political elite were willing to reform it would be impossible without instituting a competitive exam as the primary method of evaluating the candidates.

\section{Evaluating Preliminary Examinations}

The ongoing relationship between the partisanship and professionalization was expressed in the continued debates on the entrance examination instituted in 1882. Since the examination was simply the minimum for a position, it created a system where the government still selected candidates regardless of their standing in the examination. Resulting from this system, once a candidate passed the exam "he sets to work at once to bring all the pressure - political, social, religious - that he can obtain to bear upon the different Ministers of the Crown." ${ }^{350}$ Factors other than the technical still controlled

\footnotetext{
348 Ibid.

${ }^{349}$ Ibid., 16C-412.

${ }^{350}$ Parliament, Sessional Papers, 1892, 16C-558.
} 
appointments to the civil service. This was a bane to those who, by the 1890 s, were advocating for more reforms.

Those who called for a competitive examination made reference to tropes of improvement. Thorburn, for instance, linked competition with the public good: "the more thoroughly all such elements of favouritism, of whatever kind, and partisan recompense for favours, either received or expected, are eliminated from the public service, the better it will be for the country." ${ }^{, 351}$ The commissioners similarly related the quality of the entrance examination to the quality of the applicants to civil service positions. In their report, they noted that the examination was neither limiting appointments nor insuring the quality of appointments. One reason was that the questions on the examination were "of such a character that the ordinary High School boy could without difficulty pass them."352 Here we can again see the gendering and classing of the imagined civil servant. Despite the awareness of women working in the Civil Service, applicants were assumed to be male. The applicants were also assumed to have some knowledge that exceeded the basics of high school education. Even this is more precise than the language previously used. The 1881 report suggested that the examination should test "the requisite knowledge and ability to enter on discharge of his official duties. ${ }^{, 353}$ Although not terribly well defined, the 1892 report was more precise than the tautology used in 1881 . Rather than simply demonstrate the required knowledge, the commissioners explained that this meant a basic high school education.

\footnotetext{
351 Ibid.

352 Ibid., 16C-xix.

${ }^{353}$ Canada, Parliament, Sessional papers of the Dominion of Canada, Vol. 10, 4th Parliament, $3^{\text {rd }}$ Session (Ottawa: Maclean, Roger, 1881), 18.
} 
The quality of applicants was also related to the number of people who wrote the exams. Following the 1882 reforms, critics complained that more candidates took and passed the qualifying exams than there were available spaces. Peter Mitchell described these circumstances with the same acerbity with which he called for the abolition of the Civil Service Act. He referred to the examination as "a useless piece of expense," that had "created a class of officials and perpetuates sons of officials in the civil service, as a special class who look forward to no other future." These sons, he warned, "are led to look forward, as their highest object in life, to a position in the civil service, and it ruins hundreds of them." ${ }^{, 354}$ Here Mitchell showed an enduring condescension towards the civil service. As noted earlier, in the late 1850 s civil servants were seen as dependent, and consequently less than fully respectable men. Throughout the mid- and late-nineteenth century, professionalization and the rise of a middle class had done a great deal to change this attitude about respectable bourgeois labour. In the American context, Cindy Sondik Aron notes that the rise of white-collar labour changed social aspirations and goals. The growing middle class fashioned new goals of "security and the promise of an adequate (if not extravagant) salary." ${ }^{355}$ As permanent salaried work became more common, selling one's labour was less considered a forfeit of one's independence. As Mitchell's remarks indicated, however, older views of respectability and independence continued as well. James McMullen, a Liberal MP from Ontario, discussed this frequency of exams in more moderate terms. He suggested that the inequality between applicants and

\footnotetext{
${ }^{354}$ Canada, Parliament, Debates of the House of Commons, $6{ }^{\text {th }}$ Parliament, $2^{\text {nd }}$ Session (Ottawa: Hunter Rose, 1888), 131.

${ }^{355}$ Cindy Sondik Aron, Ladies and Gentlemen of the Civil Service: Middle-Class Workers in Victorian America (Oxford: Oxford University Press, 1987), 185.
} 
positions - "the evil of having a lot of young people waiting...for dead men's shoes,",356 as George Elliott Casey, a reformer and Liberal MP, called it - caused hopefuls to seek alternative means to secure an appointment. One such route was their connections with and claims upon their MPs. He stated: "I think it is wrong to encourage young men to pass an examination in the hope that they may get an appointment when there are so many on the list. ${ }^{\not 357}$ Here the criticism was not at the quality or efficiency of the examination, but rather that the examination process created a situation where too many applicants felt they had a claim to a position. McMullen concluded that this entrenched the reciprocal relationship between politician and supporter that protected patronage. Since the exam was relatively frequent there were "great many of them who are hoping and waiting and urging on their representatives to try and secure them an appointment. ${ }^{, 358}$ Despite the reforms, the appointment process still encouraged applicants to petition politicians - the letters to and claims upon politicians continued. Since it was a qualifying exam, not a competitive one patronage existed along side the reforms.

This continued reliance on patronage was met with criticism. Liberal Edward Blake characterized the qualifying exam as a screen... it is a system which, under the guise to the public of giving those advantages... of giving those advantages of getting rid of political favoritism and of securing to the most efficient an entrance into the public service, it is none of these things, but it is a system which gives the right to employ political patronage under a cloud, which gives the right to employ the least deserving instead of the most deserving without the public knowing. ${ }^{359}$

This was the core of the criticisms leveled against the Civil Service Act. It was essentially a toothless act that maintained the status quo. Despite his support for the civil service

\footnotetext{
${ }^{356}$ Parliament, Debates, 1888, 131.

${ }^{357}$ Canada, Parliament, Debates of the House of Commons, $7^{\text {th }}$ Parliament, $2^{\text {nd }}$ Session (Ottawa: S.E. Dawson, 1892), 284.

${ }^{358}$ Ibid., 284.

${ }^{359}$ Parliament, Debates, 1885, 1285.
} 
commission and excitement over the report, Casey came to refer to examinations as "a farce... they are not the sort of examinations recommended by the Government's own Commission, appointed nine years ago for the purpose of framing a system of Civil Service reform. ${ }^{„ 360}$ This type of criticism was common. As in the late $1870 \mathrm{~s}$, however, the debates over patronage in the 1880 s were more nuanced than accusations of corruption and maintain partisan influence.

The 1891-92 civil service commissioners shared these concerns over the examination's quality and effectiveness. As in 1882, the commissioners expressed their preference for a competitive examination. They referenced how this system "has worked admirably in the mother country, where it has long been in operation. It has also worked well in the United States as far as it has been adopted." For both the American and the British systems, the commissioners argued that the competitive examination "proved efficacious in correcting many long-standing abuses, and supplying the country with a class of intelligent and industrious officers, to the great advantage of the service both in the way of efficiency and economy., ${ }^{361}$

The rhetoric of improvement was, at times, also linked to democratizing the service. The superintendent of the Post Office Savings Bank, David Matheson, promoted the "competitive principle" in reference to democracy and fairness. He suggested that its value lay in "destroying privilege." If Canada desired "a people's service," he argued, then "every well educated young man from one end of the country to the other may have a perfect right to come before the examiners and be tested according to his fitness,

\footnotetext{
${ }^{360}$ Canada, Parliament, Debates of the House of Commons, $6{ }^{\text {th }}$ Parliament, $4^{\text {th }}$ Session (Ottawa: B. Chamberlain, 1890), 218.

${ }^{361}$ Parliament, Sessional Papers, 1892, 16C-xxiii.
} 
according to his standing, and to be chosen for public employment."362 The idea of a people's service underscored the difference between the politicized and technical views of the civil service. In the former, positions belonged to the government to reward its supporters. In the latter view, the civil service belonged to "the people," and positions were open to anyone who demonstrated their qualifications. This was a period of changing political definition and organization. William Dawson LeSueur, the Secretary of the Post Office Department and, according to A.B. McKillop, "the most wide-ranging Canadian-born intellectual of his generation," ${ }^{363}$ defined democratic government as one "under which the sovereign power of the State...was distributed, as the lawyers say, "per capita." "364 Of course, in the late-nineteenth century, 'the people' referred to propertied, male, British subjects. Jeff Hearn underscores this period in Britain as one "of men's relative democracy (or viriocracy: government by adult males.)"365 In Canada, the changes to the franchise opened political participation to more men. The political group 'the people' was a changing and limited category. Still, while exclusionary, this view of the civil service contrasted with the victors-spoils view relied on until the early 1880 s. Even in this (limited) new understanding, personal characteristics were still recognized as important criteria. Matheson qualified his description of 'the people,' explaining that “of course there is an element of character and conduct to be considered and physical health to be vouched for." 366

\footnotetext{
362 Ibid., 16C-123.

${ }^{363}$ A.B. McKillop, A Critical Spirit: The Thought of William Dawson LeSueur (Toronto: The Carleton Library, McClelland and Stewart Ltd, 1977), ix.

${ }^{364}$ Ibid., 165.

365 Jeff Hearn, Men in the Public Eye: The Construction and Deconstruction of Public Men and Public Patriarchies (London: Routledge, 1992), 128-129.

${ }^{366}$ Parliament, Sessional Papers, 1892, 16C-123.
} 
There was not unified agreement on the competitive exam as a democratizing initiative. These competing ideas drew from international thought and examples, where the main points of reference were England and other British colonies. In the 1892 report, Canadian administrators were more willing to criticize these examples than they previously had been. LeSueur expressed doubts that that Indian civil service had "as manly a tone as it had in the time of the East India Company." ${ }^{367} \mathrm{He}$ went onto doubt whether "we can cite the English Civil Service as being very superior to our own in point of efficiency. ${ }^{368} \mathrm{He}$ did not elaborate these criticisms, but this is a more confident position than previously demonstrated. Rather than simply attempting to follow British examples in the metropole or in the colonies, Canadian administrators were now critically engaging and debating them.

Alfred D. Decelles, Parliament's General Librarian, expressed mixed opinions about the examination. He conceded that a competitive examination would eliminate a large number of unsuitable candidates. He explained that due to the size and diversity of the country, it was unlikely to be introduced. This resulted from "our seven provinces and

\footnotetext{
${ }^{367}$ Ibid.,16C-615. The connection of masculinity to the Indian Civil Service was also a widespread trend. In Colonial Masculinity: The 'Manly Englishman' and the 'Effeminate Bengali' in the late nineteenth century, Mrinalini Sinha provides a close reading of the Indian Public Service Commission's papers, British and Indian newspapers, and British parliamentary addresses. Sinha argues that the "the Commission was poised to exploit the differences between Hindus and Muslims from making the British-dominated covenanted service even more exclusive than before." Sinha goes on to suggest that "the spectre of 'Bengali' and 'Hindu' domination at the competitive examination was thus disingenuously deployed by several AngloIndian witnesses to mask their own hostility towards allowing natives to compete at the competitive examination in London," 111.

${ }^{368}$ Parliament, Sessional Papers, 1892, 16C-615. William White made a similar argument about the British system. To the commissioners he explained that although Britain had a competitive exam and Canada had a pass system, it was not clear that the British system was superior. His doubts came from the longstanding questions over the effectiveness of a competitive examination. He stated that simply passing the exam evidenced the educational requirements necessary to perform the required duties. On the other hand, he continued, "the ability to pass the most brilliant examination is no necessary indication of the zeal and energy which are the chief factors in the efficiency of a clerk," Parliament, Sessional Papers, 1892, 16C698.
} 
our differences of races and religion, each section claiming its share of the patronage."369 LeSueur was even more sceptical of the use of a competitive examination. LeSueur was one of few administrators to support a preliminary exam, rather than a competitive one. In addition to being a civil servant, LeSueur also wrote on the relationship between morality and politics across the Anglo-American world. He stressed that politics must be guided by clear moral convictions, if it was to overcome self-interest. ${ }^{370}$ He repeated this idea in the 1892 report. When interviewed, he explained that if control of appointments was given to a "non-political board," it would attract "that class of persons who are of quiet, sedentary habits, who have a good deal of time for study, not much inclination to engage in business pursuits, and somewhat lacking in initiative and enterprise - the very kind likely to stand well in an examination." 371 The critical reference to sedentary habits reflects the type of active masculinity and character that was desired in a civil servant more than men who were good administrators, they also had to be physically and politically active citizens. $^{372}$

Despite the range of positions expressed, in general, the commissioners found the qualifying examination unsatisfactory. Adding to this, they also worried that if an applicant was a supported by an administrator or a politician "a number of trials have been allowed before they finally passed." 373 The actual purpose of the exam was one

\footnotetext{
${ }^{369}$ Parliament, Sessional Papers, 1892, 16C-528.

${ }^{370}$ McKillop, A Critical Inquiry, xvi, 161.

${ }^{371}$ Parliament, Sessional Papers, 1892, 16C-614.

372 The relationship between physicality, morality, intelligence and masculinity was a significant concern across the transatlantic world in this period. As Mrinalini Sinha, Colonial Masculinity: The 'Manly Englishman' and the 'Effeminate Bengali' in the late nineteenth century (Manchester: Manchester University Press 1995) suggests for India and Gail Bederman, Manliness and Civilization: A Cultural History of Gender and Race in the United Sates, 1880-1917 (Chicago: University of Chicago Press, 1995) for the United States, these concerns were often combined with concerns about race.

${ }^{373}$ Parliament, Sessional Papers, 1892, 16C-xix. This was a reasonable concern. One Conservative MP from New Brunswick, Pierre Amand Landry, noted that "I do not hesitate to say that where everything else
} 
aspect that complicated this debate. This suggests that the examination simply became part of the patron-client relationship, rather than a tool to eliminate patronage. Again we can see the fragmented processes of state formation. Rather than one appointment system replacing the other, new and old traditions coexisted and interacted. The resiliency of patronage was partially a result of politicians and their supporters adapting to the new context.

\section{Monitoring Examinations}

The 1892 commissioners were not able to replace the entrance exam with a competitive one. They did, however, add another level of specificity to the process. They distinguished between a preliminary examination and a qualifying examination. The former was for lower grades, the latter higher grades. ${ }^{374}$ Although not making the civil service competitive, having separate exams created another level of regulation in the appointment process. The preliminary examination tested penmanship, orthography, arithmetic, and reading. Each subject was marked out of 60 and candidates required an average of 50 percent or more. The examination tested technical skills. The reading examination was "for the purpose of ascertaining that none of the candidates stutter or are short-sighted." ${ }^{375}$ Yet even in the most technical of contexts, it was difficult to avoid the expression of cultural sensibilities regarding things like self-government. For example, an 1894 orthography passage was on "Missing Great Chances," and warned young men not

equal - I do not say you should appoint or promote men who are manifestly unfit for office - but where persons are equal in ability, equal in other respects, equal in honesty or integrity, I say that the Government should favor their supporters," Canada, Parliament, Debates of the House of Commons, $6^{\text {th }}$ Parliament, $1^{\text {st }}$ Session. Ottawa: MacLean, Roger, 1887, 666.

${ }^{374}$ LAC, Department of Militia and Defence Fonds, RG9-II-A-1, Vol. 223, file no. A8758, P. LeSueur to Governor General in Council, 22 October 1888. Positions in the Lower Grades included messengers in inside and outside, porters, sorters, packers, letter carriers, mil transfer agents, box collectors, tidewaiters, assistant inspectors of weights and measures, temporary copyists. The higher grades included third-class clerks in certain departments.

${ }^{375}$ Parliament, Sessional Papers, 1895, 16B-36. 
to "luve pleyshure moore than studdy," at risk of taking a "loer graid ov wurk bekaus ov yoore falur" (sic). ${ }^{376}$

The qualifying examination was more precise than the preliminary ones. The categories were: penmanship; orthography; arithmetic, including interest, vulgar and decimal fractions; geography (mostly Canadian); history (mostly Canadian, but with some British and French); grammar; composition; transcription. There were also optional examinations in: composition in another language; translation from secondary language; précis-writing; book-keeping by double entry; shorthand; type-writing. Subjects were valued marked out of 100 . To qualify for a position, candidates had to pass all exams. If a single examination was failed, they could rewrite that subject at the next examination. ${ }^{377}$

The qualifying exams were more explicit in combining technical and political knowledge. The history exam focused on political history. Candidates had to answer questions on Canadian-U.S. relations, reciprocity, and the causes of Confederation. The history exam, from 1894, had central-Canadian bias, with eight of the twelve questions focusing on Upper and Lower Canada, prior to $1867 .{ }^{378}$ Other exams also related directly to politics. The passage to be translated from English to French was taken from a Thomas D'Arcy McGee speech on the relationship between reading/writing history and patriotism. The précis-writing exam featured a long passage on the laws governing military and naval service with other nations, loyalty, and illegal shipbuilding. ${ }^{379}$ As with the preliminary examination, even the tests that were not explicitly political had a focus

\footnotetext{
${ }^{376}$ Ibid. Since it was an orthography exam, the passage was badly misspelled. Candidates were deducted five marks for every word they failed to spell correctly.

${ }^{377}$ LAC, Department of Militia and Defence Fonds, vol. 223, file no. A8758, P. LeSueur to Governor General in Council, 22 October 1888.

${ }_{378}$ Parliament, Sessional Papers, 1895, 16B-39.

${ }^{379}$ Ibid., 16B-41-43.
} 
on self-government. The orthography section in the 1894 qualifying examination was 'Counsel to Young Men." This passage included a range of advice on how behave in private and in public, at home and at business. ${ }^{380}$ The exams' focus suggests that the ideal civil servant was someone who had both technical and political knowledge. He was also someone who was a respectable young man - one that would ideally marry and respectably govern a household. Even as quantitative measures replaced personal connections in the appointment process, personal characteristics and private behavior remained part of the thought surrounding civil servants. This fits with liberal governmentalities that rose to prominence in the nineteenth century. Such a rationality, Foucault noted, must "act on the consciousness of people, not just to impose some true or false beliefs on them.... in such a way that their opinion is modified, of course, and along with their opinion their way of doing things, their way of acting, their behavior as economic subjects and as political subjects." 381 The passages selected for the orthography and penmanship exams reinforced ways of acting. These passages did not address politics. They did, however, reinforce how the potential civil servants - usually young men - should act.

One of the processes of state professionalization was to introduce standardized methods and regulations. As part of this, the 1892 Civil Service Report outlined a series of possible offences regarding the examination. Punishable offenses (as defined in the Civil Service Act) included impersonating a candidate, letting someone else take the exam for them, and attempting to procure an examination paper or any questions relating to the exam without authority. Anyone found guilty could be imprisoned for up to six

\footnotetext{
${ }^{380}$ Parliament, Sessional Papers, 1895, 16B-40.

${ }^{381}$ Michel Foucault, Security, Territory, Population: Lectures at the Collège de France, 1977-1978, Michel Senellart, ed., Translated by Graham Burchell (New York: Palgrave Macmillan, 2004), 275.
} 
months, fined up to $\$ 200$, and, if already employed in the civil service, dismissed. ${ }^{382}$

These conditions proved necessary; there were several instances of examination fraud in the early 1890s. John McGillicuddy, an employee in the Printing Bureau, was charged with selling promotion examination papers to mail clerks in $1891{ }^{383}$ In 1894 , A.J. Prud'homme and Louise Williams were disqualified from the civil service, after it was found that Williams had copied Prud'homme's arithmetic examination. ${ }^{384}$ In 1893, there were also three cases of impersonation reported; two were attempted and stopped, while one was successful. ${ }^{385}$ On one level the laws served a pragmatic purpose. They protected the integrity of the examination. These laws also served a more symbolic purpose: to enhance the Civil Service Board's authority. It gave them the legal power to discipline and punish anyone who tried to circumvent their rule. Here administrators used the law to forge a system that entrenched their own authority.

Drawing from Foucault, Timothy Mitchell distinguishes between power and discipline. The latter is internalized and manifested though individual choices. The former, on the other hand, "operates by setting external limits to behavior, establishing negative prohibitions, and laying down channels of proper conduct." ${ }^{386}$ Pierre Bourdieu connects this idea of power to the processes of modern state formation. This process, he argues, is underlined by "shift from a diffuse symbolic capital, resting solely on collective recognition, to an objectified symbolic capital, codified, delegated and

\footnotetext{
382 Parliament, Sessional Papers, 1892, 16C-xliv.

${ }^{383}$ LAC, Department of Justice Fonds, RG13-A-2, vol. 94, file no. 871, P. LeSueur, Secretary of Board of Civil Service Examiners, to Deputy Minister of Justice, 26 September 1894, 24.

${ }^{384}$ LAC, Department of Justice Fonds, vol. 95, file no, 899, P. LeSueur, Secretary of Board of Civil Service Examiners, to Deputy Minister of Justice, 21 September 1894.

${ }^{385}$ Parliament, Sessional Papers, 1895, 16B-8.

${ }^{386}$ Timothy Mitchell, "Society, Economy and the State Effect" in George Steinmetz, ed., State/Culture: State Formation after the Cultural Turn (Ithaca: Cornell University Press, 1999), 86
} 
guaranteed by the state, in a word bureaucratized." ${ }^{387}$ By outlining illegal practices, and establishing official repercussions, the civil service commissioners were entrenching their bureaucratized authority. Whereas just a few decades earlier the qualifying examination for the civil service was optional, now it was mandatory, regulated, and its legitimacy was protected by official laws. In addition to determining who qualified for positions, they also developed the means to punish anyone who attempted to circumvent their authority.

\section{Everyday regulation}

The recommendations made in 1892 demonstrated the increasing rationalization of state practices. The processes of replacing political influence with professional independence were accompanied by expanding standards and rules that could be applied evenly to each department and location. This standardization applied to appointments and promotions, but also to more quotidian practices, such as book-keeping, attendance, hours of work, and supervision. Since these relations were understood as regularities it meant they could be governable, reproducible and predictable. Increased record-keeping and evaluations allowed administrators to govern the regular, daily behaviour of their employees. Since these data were used to reward or punish them, it motivated workers to meet departmental expectations. Any civil servant who desired a promotion, or even jobsecurity, had constantly to be meeting the standards and expectations set by department heads and the Board of Civil Service Commissioners. This also encouraged the civil

\footnotetext{
${ }^{387}$ Pierre Bourdieu, "Rethinking the State" in Steinmetz, State/Culture, 65-66. Mark Neocleous's Administering Civil Society: Towards a Theory of State Power (London: Macmillan Press, 1996) makes a similar point. He writes that "Because law structures social reality its deference to administration is a necessary requirement for administrative power. For administration to be regarded as normal and right law must render it so" (163).
} 
service to be more self-governing, since authority was taken from politicians and given to professional administrators.

The report refers to these practices as the "internal economy of departments., 388 "Economy" is the key word, as it refers to a general, managed order of things. Just as finances must be properly kept, internal economy highlights the need to do the same for offices, employees, practices and records. More generally, the proposed system was referred to in terms of introducing "business methods...in the internal organization of the service." ${ }^{389}$ As the civil service grew in size and in scope, this type of regulation became more necessary. The commissioners emphasized that a "considerable part of the work in Ottawa consists of supervising, checking, and directing the work done by officers of the Government...in all parts of the Dominion." ${ }^{390}$ Clearly defined practices were easier to reproduce and to monitor at a distance. After 1892 this work was manifested in annual reports to Parliament. Again, this is an example of constant supervision. One disciplinary technique in the civil service was ongoing evaluation. Annual reports reproduced this evaluation through all levels of the service. The commissioners were responsible to Parliament just as clerks were responsible to their department heads.

One of the significant concerns of the Civil Service Commission was how to make the service more efficient. This applied to the quality of employees and to departmental work. The commissioners noted that resulting from the distance between different officers there was "great waste of time is occasioned by the necessity of writing notes, references, and memorands [sic], and writing replies to them or by the necessity of

\footnotetext{
${ }^{388}$ Parliament, Sessional Papers, 1892, 16C-xx. The suggested work hours were 9:30-5. Officers could leave at 4 if they were not busy and their deputy gave them permission, but not earlier. (xxv)

${ }^{389}$ Parliament, Sessional Papers, 1892, 16C-xciii.

${ }^{390}$ Ibid., 16C-Xv.
} 
sending for officers from other buildings, all of which detracts from efficiency." ${ }^{391}$ To eliminate this, they turned to a still-pressing issue in bureaucratic management: reductions. The commissioners proposed finding examples of overlap and duplication of work, and simply not replacing certain positions when a vacancy occurred. They suggested this method for it did not punish those currently employed. As a vacancy occurred it would provide an opportunity for review and evaluation. ${ }^{392}$ This system would eliminate the "tendency to make promotions for the benefits of officers who had reached the maximum salaries of their class, whether vacancies in the higher class existed or not, and for that purpose to create unnecessarily higher class clerkships."393 The process of making the civil service more efficient, in this instance smaller and less expensive, was established as an ongoing process. The rhetoric of efficiency and economy was codified into the actual management of the civil service.

Another step in these processes of professionalization and governmentalization was making clearer the chains of command. Permanent employees in the inside service were divided into first and second divisions. The first division included deputy heads, officers with special professional or technical qualifications, chief clerks, first-, second-, and third-class clerks. The second division was made of those doing more temporary tasks: shorthand writers, typewriters, précis-writers abstractors, indexers, copyists, writers generally; messengers, overseers, packers, sorters, and persons filling like positions. $^{394}$

\footnotetext{
${ }^{391}$ Ibid., 16C-xxv.

392 Ibid., 16C-xxvii.

${ }^{393}$ Ibid., 16C-xx.

${ }^{394}$ Ibid., 16C-xxix, 16C-xxx. As in 1882, the outside service was given less systematic analysis. The commissioners wrote that "Outside Service includes all persons employed in the Civil Service otherwise than on the departmental staffs at Ottawa, and the Governor in Council may divide the same into two divisions, to be known as the first division and the second division, and determine what classes of officers
} 
This division was more precise than that made in 1882 . The hierarchy of the departments was more clearly outlined. It followed that as workers were held more accountable to their superiors, they would become less malleable by and reliant on political influence. Related to this were attempts to make deputy heads as independent from political influence as possible. The Globe applauded this process, explaining that currently deputy heads were "afraid to call their souls their own and refuse to answer the simplest question concerning public departmental affairs without consulting the Minister. ${ }^{395}$ The commissioners were in favor of Ministers being involved in the department. After all, they had to report their department's work to Parliament. Ministers also usually had business experience that was useful. If they were too close to the department, though, it tended "to bring the administration of public affairs somewhat too closely into contact with politics." ${ }^{396}$ Since politicians were still involved with the civil service finding the balance between politics and administration was an ongoing process. By making the departments more independent, and the office hierarchy better established, the commissioners were attempting to remove political influence from administration, while simultaneously seeking to governmentalize it. This was not a perfect process, but it reflected more detailed and thorough organization than the previous report.

To insure that departments were free from political interference, the commissioners called for the establishment of a permanent board, the Civil Service Commission of Canada, to oversee the whole bureaucracy. The commission would be made up of five people: a chairman, who was to be an "experienced permanent member,"

or employees shall belong to each division, the relative grades of the different classes in the Outside Service, and all matters incident to appointment and promotion therein, not herein otherwise provided for" (16C-xxx).

${ }^{395}$ The Globe, "The Civil Service," 19 May 1892, 1.

${ }^{396}$ Parliament, Sessional Papers, 1892, 16C-xx. 
and an advisory council of four deputy heads. ${ }^{397}$ Reflecting the state's linguistic concerns, the commissioners specified that at least one member of the board should be a FrenchCanadian. The government of the day would appoint the Board, "in the manner customary with officers of a superior class," and the commission would report annually to Parliament. ${ }^{398}$ The commission would have a staff that included a secretary and an accountant.

The commission's duties included appointing and monitoring all civil service examiners and assistant examiners. In general the commission would be responsible to test and evaluate all candidates for appointment and promotion, and periodically to investigate and report on the "state and management of public business, and the official conduct of public servants. ${ }^{, 399}$ Management of public business and conduct meant keeping track of the division of labour, establishing standard bookkeeping, hours of work, lunch, monitoring absences, and issuing fines for "non-attendance or slight deviation from established rules." 400 Attendance registers facilitated this process of governmentalization. They recorded when officers arrived and left, making individuals into subjects whose habits were monitored and recorded. These registers would in turn help the commissioners inspect the department as a whole.

The focus on standardizing everyday practices was part of a modernizing project. In The Hero and the Historians, Alan Gordon argues that "modernity reordered and expanded social relations in ways that broke down older communal face-to-face

\footnotetext{
397 The Globe, "The Civil Service," 19 May 1892, 1.

${ }^{398}$ Parliament, Sessional Papers, 1892, 16C-xxi.

399 Ibid., 16C-xxii.

${ }^{400}$ Ibid. The Globe suggested that "when not otherwise engaged the commissioners might make inquiries on behalf of the Government in matters of public expenditure and cognate subjects, thereby saving the cost of special commissions." "The Civil Service," 19 May 1892, 1.
} 
associations." ${ }^{401}$ Patronage was (and continued to be) reliant on personal associations. Letters asking for positions or asking for references attempted to create these relationships, even if they were from a distance. Reforms to the civil service aimed to remove this personal aspect, replacing it with standardized and monitored practices. The commissioners were self-aware about this project. They championed departments that demonstrated "the spirit of invention and improvement at work in various officers." $" 402$ At the same time, they were critical of departments that continued to rely on "cumbrous and old-fashioned methods of keeping accounts, copying letters and conducting business generally. ${ }^{403}$ New methods were praised, while old methods were decried as being inefficient. The supervision of a civil service board would get rid of these outdated methods, while helping all departments benefit from improving initiatives. These new methods would be made standard, and implemented in every department across the country.

The permanent Commission's reach highlights the interaction between professionalization, rationalization and state formation. It was a bureaucratic solution to the problem of governing the bureaucracy. The civil service commissioners recommended establishing a permanent administrative body to monitor and evaluate the civil service. Because the permanent commission would be made up of experts, they would be best qualified to judge departmental efficiency. Since the commission "will have no patronage to exercise, and will be free from even a suspicion of acting from

\footnotetext{
${ }^{401}$ Alan Gordon, The Hero and the Historians: Historiography and the Uses of Jacques Cartier (Vancouver: UBC Press, 2010), 3.

${ }^{402}$ Parliament, Sessional Papers, 1892, 16C-xxxi.

${ }^{403}$ Ibid., 16C-lxxxi. Not surprisingly, these 'old-fashioned' methods were contrasted with "business-like methods."
} 
interested motives," the only methods to evaluate civil servants would be technical - their ability to perform their jobs. ${ }^{404}$

Another method to facilitate better management of the civil service was the spatial organization of the offices. The commissioners observed that the officers were divided into small rooms, which separated employees whose work was related. These divisions also meant that "facilities for idling and talking and seeing visitors were greatly enlarged, to the detriment of the work." 405 These inefficiencies were exacerbated by the fact that the divisions made supervision by the deputy head more difficult. The current system, the commissioners, argued was inefficient. It created "an immense waste of power." 406 The solution to this was to rearrange the offices to better allow the supervisor to monitor workers. ${ }^{407}$ The commissioners recommended the "well known principle that to ensure proper performance of work, supervision, and discipline, in a business office, the chief responsible officer must be in a position to have an efficient purview and close communication with his subordinates, and the proper grouping of men whose work is related."408 The commissioners returned to the trope that the civil service should be managed like a business. This passage further presented striking governmental overtones. As the supervisor is better able to manage those below him - in this instance to literally discipline and monitor them - the workers will better govern themselves.

The problem of corruption in the examination process was similarly related to supervision and the physical spaces in which exams were written. In their 1893 report,

\footnotetext{
${ }^{404}$ Ibid., 16C-xxii.

${ }^{405}$ Parliament, Sessional Papers, 1892, 16C-lxxxii.

${ }^{406}$ Ibid., 16C-lxxxii.

${ }^{407}$ This same process of reorganization and disciplining was happening in late-nineteenth-century factories. Jeremy Stein, "Time, space and social discipline: factory life in Cornwall, Ontario, 1867-1893," Journal of Historical Geography, 21:3 (1995): 278-299.

${ }^{408}$ Parliament, Sessional Papers, 1892, 16C-xxv.
} 
the civil service examiners wrote that copying might result from "inability of the examiners to exercise a perfect supervision of the candidates while at work." ${ }^{409}$ They hoped that better spaces - spaces that would allow better supervision - would be provided in the future. The relationship between proper conduct, supervision, and space was made explicit in this concern. Though ideally civil servants would be self-motivated and self-disciplined, the commissioners realized that both candidates and employees needed to be supervised to guarantee proper behavior. This supervision was spatial as well as documentary and hierarchical.

The relationship between the quality of supervision and the quality of work was one of the areas which the commissioners suggested a permanent civil service commission would be of use. They found that too often there was "an absence of that esprit de corps which ought to animate and usually does animate the members of the same body or service." ${ }^{410}$ By establishing standardized practices, making departments more efficient, and facilitating cooperation between the different departments, the commission would improve the quality of work, and the disposition of workers. Surveillance of work, workers, and workspaces was too important to be left to discretion of various departments and their administrators.

\section{Regulation and Improvement}

One of the promoted outcomes of these reforms was an improved political culture. The commissioners argued that their modernizing initiatives would lead to better quality civil servants, selected according to merit rather than favoritism. Eliminating favoritism was also directly linked to electoral and parliamentary politics. Their logic

\footnotetext{
${ }^{409}$ Parliament, Sessional Papers, 1893, 16B-7.

${ }^{410}$ Parliament, Sessional Papers, 1892,16C-xxiii.
} 
suggested that politicians would have to rely on their records and their policies to garner support once patronage could not be relied on as a campaign strategy. Again there is an authoritative and exclusionary aspect to this suggestion. The commissioners' view of improved political culture was one that followed their suggestions and gave them more authority. The quality of civil servants was measured through rubrics that they created and recorded on forms that they sanctified.

The recommendations in the report were supported with reference to the appointees' personal qualities. With a competitive examination, the commissioners promised that "[i]ntelligence and capacity will meet with their due reward, politics and favouritism will cease to dominate." Rather than make appointments based on party or personal connections, only an applicant's measurable abilities would be considered. By highlighting the separation of politics from the civil service, the passage highlights the process of professionalization. The result of this process, the commissioners suggested, was that "the service will soon become attractive to many persons who now seek other avenues of employment, and in general the title of public servant will be an honour to be coveted. ${ }^{, 411}$ By eliminating favoritism, a better quality of applicants would be attracted. Here, the commissioners did not make an explicit reference to business-qualities. Nevertheless, the passage implied a belief in liberal governmentality. Properly selfpossessed applicants would not want to work under a system where partisan concerns were more important than measurable qualities.

Having a better-regulated system for promotion was also part of the process of improving the quality of civil servants. The Globe generously explained that "the civil service is not made up of poltroons or sycophants, and that the efforts of these gentlemen

\footnotetext{
${ }^{411}$ Parliament, Sessional Papers, 1892, 16C-xxvii.
} 
sometimes bring down upon their heads epithets which anyone else would deeply resent." ${ }^{, 412}$ The current system of promotions made employees too dependent on the whims of politicians. The commissioners wanted promotions to result from seniority. The permanent civil service commission would oversee these promotions. A permanent board would further contribute to establishing regulations by providing avenues for redress if an applicant felt they had been unfairly passed over. Relating opportunities for advancement to performance, not politics, would attract the type of self-governed applicants that should fill the civil service. The commissioners explained, "men should look to the positions in the grades above them as the natural rewards of service, ability and diligence, and nothing is more discouraging to them than to find that some one has been brought into the department and appointed over their heads. ${ }^{, 413}$ Making promotions the result of measurable performance history created incentives for employees to be self-governing. Standardizing practices would attract the type of worker that typically sought employment in the business communities - rational, ambitious, and self-disciplined.

As the civil service was professionalized "no man or woman who aspires, as all have a right to aspire, to any such position, will have occasion to seek or use any influence less honourable than his or her own merit and fitness for office." ${ }^{.414}$ The commissioners connected professionalization with personal characteristics and ideas of government. Although vague and intangible, the idea of honour fits with the expectation that political citizens would follow through on their responsibilities and their expectations. This demonstrates professionalization as a process of state formation, since civil servants were judged on their individualized performances, rather than on partisan

${ }^{412}$ The Globe, 1 September 1893, 2.

${ }^{413}$ Parliament, Sessional Papers, 1892, 16C-14.

${ }^{414}$ Ibid., 16C-xxvii. 
criteria. This was an example of disciplinary power fostering self-government. Reforming rhetoric hoped that better practices would produce better applicants ${ }^{415}$

The above statement is one of the few instances where women were considered alongside men in discussions of the appointment processes. Women's place and performance in the service was one of the areas investigated by the commissioners. This was a marked shift from the pervious decade. Although women were allowed to enter the civil service after 1882 , they were still not often considered in debates. ${ }^{416}$ Attuned to the new presence of women in the bureaucracy, the 1892 Civil Service Report more explicitly addressed the gendered civil servant. The commissioners distinguished between male and female employment in their report's preamble. Men, according to the commissioners, usually "render services of a professional character, such as engineers, architects, etc, and are men of high education and experience. ${ }^{, 417}$ From their assumed skill and training, men were given permanent positions and expected to advance. Women were limited to positions in the temporary class. ${ }^{418}$ The differences outlined here reflect how work was conceived differently for men and women. That the commissioners explained what type of man would be required for professional positions implied that there were some men who by experience, character or education were better qualified than others. Women were, at least rhetorically, considered a more homogenous group.

\footnotetext{
${ }^{415}$ Mitchell, "Society, Economy and the State Effect," 86.

${ }^{416}$ Among the amendments made to the Civil Service Act throughout the 1880s, only one mentioned women. In 1883, Joseph-Adolphe Chapleau proposed that copyists be included on the list of positions that require the qualifying and preliminary exams. He stated that "the main reason of this amendment is that a certain number of female writers seek employment in the Departments who should not be assimilated to third class clerks because they are not getting any of the benefits of the Act for superannuation or promotion." Canada, Parliament, Debates of the House of Commons, $5^{\text {th }}$ Parliament, $2^{\text {nd }}$ Session, (Ottawa: MacLean, Roger, 1884), 1388.

${ }^{417}$ Parliament, Sessional Papers, 1892, 16C-xvi.

${ }^{418}$ In 1891, for example, 28 women were hired to prepare the census. Rather than being placed on salary, these clerks "were paid strictly for the amount of work they do." Their earnings ranged from 6.25 to 43.5 cents per page complied. Parliament, Sessional Papers, 1892, 16C-xvi.
} 
Related to this conceptual monolith, temporary positions did not require passing the entrance examination. The reforms offered by professionalization were not extended to women. The governmentalization of the civil service was as a gendered process. As the civil service was increasingly monitored and detailed, it was increasingly thought of in masculine terms. In not extending these standardizing practices to women it further marginalized their place within the service, and further excluded them from the construction of the ideal civil service. ${ }^{419}$

In each interview with department heads and deputy heads the commissioners included a single entry about women clerks. They asked if any women were employed in the department, and how efficient was their work. They also asked if there were any work in which only women could be employed. Neither the North West Mounted Police nor by the Department of Militia and Defence employed a single woman. The deputy minister of Militia and Defence explained that was because clerks "are not required." ${ }^{420}$ Other departments were slightly more open to the presence of women, and reported that they were "very efficient in their work." ${ }^{421}$ Regardless of the positive reports, some administrators were still concerned about women's presence in the service. Antoine Gobeil, the Deputy Minister of Public Works, noted that there were two women in the office and they "render very good services, and are both very efficient." Despite this fact, he stressed, "I personally prefer the employment of men. The women clerks may be as good as men, but they are not better, and the discipline required in the department can, I

\footnotetext{
${ }^{419}$ In Men in the Public Eye, Jeff Hearn explores this process in Britain. He refers to it as a process of domination, whereby certain men entrench their rule over other men and over women. In bureaucracies, this was achieved by including women in the organizational structure but in limited and restrictive ways. Hearn, Men in the Public Eye, 157-159

${ }^{420}$ Parliament, Sessional Papers, 1892, 16C-289, 16C-146.

${ }^{421}$ Ibid., 16C-95.
} 
think, be better enforced when dealing with men than with women." ${ }^{422}$ Given the rising importance of empirical evidence in administrative issues, this is a revealing statement about the prejudices women faced in constructions of public work. It was not enough for women clerks to be as good men; to justify their place in the department, Gobeil thought they would have to be better. When the evidence suggested that they were qualified, he turned to stereotypes about discipline. ${ }^{423}$

Departmental and staff discipline were not the only objects of improvement. Reforming initiatives were also connected to supervisors and to politicians. The Globe lamented evolution of the relationship between the Government and the party, resulting from the distribution of patronage. "Instead of being leaders responsible to the party that elected them," the newspaper explained, "they are its masters, requiring and... receiving unquestioning allegiance." 424 This limits political debate. The newspaper goes on to conclude that "the worst effect.... is that Parliamentary government in being degraded to such a condition political ethics which is in every way antagonistic to it." ${ }^{, 425}$ This is a stronger stance than those taken a decade earlier. The Globe described patronage as

\footnotetext{
${ }^{422}$ Ibid. 16C-467. Regarding the Canadian census of 1861, Bruce Curtis highlights similar patriarchal assumptions in social observation. Male enumerators preferred male informants and tended to treat female respondents with skepticism. In the recording of employment itself, these enumerators assumed married women would not work, and if they did was seen as a "civil disabilit[y]." Bruce Curtis, "On the Local Construction of Statistical Knowledge," 426.

${ }^{423}$ In Discipline and Punish, Michel Foucault explained how the disciplinary practices control, regulate and order every personal, social and economic detail. "In discipline," he writes, "the elements are interchangeable, since each is defined by the place it occupies in a series, and by the gap that separates it from others. The unit is, therefore, neither the territory (unit of domination), nor the place (unit of residence), but the rank: the place one occupies in a classification. Michel Foucault, Discipline and Punish: The Birth of the Prison, Alan Sheridan, trans (New York: Vintage Books, 1979), 145. Patrick Joyce expanded on this idea in his study of the liberal, British city. He writes: "the question of defining what entities should be represented might be as much a matter of exclusion as inclusion (inclusion being marked, for example, by the possession of reason, independence, the holding of property, and by male identity, among other definitions of the political nation)." Patrick Joyce, The Rule of Freedom: Liberalism and the Modern City (London: Verso, 2003), 99.

${ }^{424}$ The Globe, 9 July $1892,4$.

${ }^{425}$ Ibid.
} 
degrading and opposed to political ethics. This is a much more critical view than the business-as-usual approach previously seen. It is also a view that criticized the politicians relying on patronage, rather than would-be civil servants attempting to find and secure employment.

One element that did not change from the previous decade was that there were sometimes contradictory views expressed about patronage. The Globe noted the difference between "legitimate and illegitimate patronage which any Government can exercise. ${ }^{, 426}$ Legitimate patronage, for example, included yearly expenditures in newspaper offices. Illegitimate patronage was attempting to influence a newspaper, described as "simply the spoils of party." $" 427$ This is a different issue than appointments. It still reflects, however, the changing views on influence and professionalism. The patronclient relationship was being re-imagined in terms of independence and political improvement. The Globe compared a newspaper selling its influence to a man selling his vote. The latter was "despised," while the former was "an object of contempt and not the guardian of public freedom." ${ }^{428}$ Independence for newspapers and for civil servants was in the public interest. Those in a position to benefit from traditional avenues of power sought to maintain those methods. The rhetoric used to promote these methods had changed and the language of patronage was combined with that of political reforms.

One of the promoted outcomes of civil service reform was the positive effect it would have on the population as a whole. Liberal Party leader Edward Blake made this point: "A gift blindeth the eye," he explained, "and in all times a principal danger to popular institutions has arisen from the corruption of those charged with the conduct of

${ }^{426}$ The Globe, 10 September 1891, 9 .

${ }^{427}$ Ibid.

${ }^{428}$ Ibid. 
public business. ${ }^{429}$ This was a partisan accusation, but one made in governmental terms.

Blake suggested that those at the top set a bad example, which harmed all public

business. Blake went on to make this a class issue. He explained that the

temptations with reference to money, wealth, patronage, offices... more seriously affect us who are not absolutely beyond the reach of want, affect us who are dependent upon our continued exertions for the maintenance of ourselves and our families, than they do the man who is very wealthy; not, God forbid, not because the poor man is of less noble nature - it is not so - but because his circumstances, in the very nature of things, intensify the temptations in his case. ${ }^{430}$

It was up to the elites to set this right. As the politicians better governed themselves, those who were dependent would fall into line. The Globe similarly argued that the bad habits resulting from patronage "cannot at once by unlearned." The writer hoped, however, that once patronage was eliminated it would "deprive professionals of their chief present motive for following politics. The taxes which now infest, the wheat will presently wither away, and the old enemy will have to sow a fresh crop of some other kind. ${ }^{431}$ The paper, like Edward Blake, presented a vision for the future based on reform and improvement of the past. A better quality of politics, debate, and administration were the promised result of reforming the civil service.

Civil service reforms were based in changing ideas of political economy, government, and administration. These shifts, however, were not linear movements from corruption to democracy, nor from partisanship to professionalism. Rather, they were part of the multitude of processes of state formation. As new political orders emerged existing political traditions continued to be important. Members from both the Conservative and

\footnotetext{
${ }^{429}$ The Globe, "The Testimonial System," 6 February 1892, 6.

${ }^{430}$ Ibid.

${ }^{431}$ The Globe, 19 January 1889, 12.
} 
Liberal parties took, at times, contradictory positions regarding political patronage and the civil service. Despite a shared rhetoric about reform and professionalization, politicians from both sides attempted to use the public service for personal and partisan gain. These ways of speaking about politics coexisted, and were applied differently depending on the particular circumstances and audiences.

The 1882 reforms and the amendments regarding supervision, payment, and expenditure made in 1892, made serious structural changes to the Canadian civil service. These changes, however, did not stop politicians from using patronage, which was not officially barred until 1908. The moderate nature of the reforms was such that patronage and reform coexisted and interacted. This was especially the case with instituting a qualifying rather than a competitive exam. While it set a minimum level of qualifications for receiving a position, recommendations and personal connections were still crucial.

Debates over patronage and the civil service were more than just administrative changes. These rhetorics also reflected ways of thinking about politics. The different positions staked were based on ideas of political interests, professionalization, and public service. As politicians attempted to adapt to new circumstances while maintaining their control over political networks, they sometimes expressed seemingly confused and contradictory ideas and beliefs. These navigations were further complicated by attempts to place them in a variety of different local contexts. Calls for civil service reform were accompanied by the attempts to maintain, and increase, existing tools for political control. This was a period when patronage was being re-cast as "corruption" but this change unfolded incrementally and unevenly over both time and space. Local 
expectations of patronage coexisted with federal calls for professionalization of the civil service rather than being uniformly replaced by them.

Neither the Civil Service reforms of 1882 nor the suggestions made in 1892 succeeded in eliminating patronage. This does not mean they should be viewed as failures. Even though patronage continued, Canada's civil service became more sharply defined, more closely regulated, and better archived - in short, it was more governed than it previously had been. As we will see in the following chapters, as these changing constructions of the civil service were both challenged and drawn upon by those seeking patronage. 


\section{Part Two}

Asking for Appointment:

Patronage Letters, 1856-1896 


\section{Reading and Writing Patronage: A Social-Intellectual History}

This dissertation has, so far, mostly examined official public documents. It has outlined the changing political and rhetorical situations of the mid- and late-nineteenth century. This was a period when patronage and its role in the civil service was often debated and challenged. The dissertation now turns its focus to letters requesting patronage appointments. Such letters were all written with the same goals - to get a job or to recommend someone for a job. They used different strategies and reflected different lives. As such, they can be read in multiple ways.

An important influence on this approach is Cindy Sondik Aron's study of the American federal civil service. Aron effectively uses patronage requests to explore what type of people entered the civil service and shows the links between salaried government employment and the development of the middle class. She notes that those without personal contacts use letters to establish their political credentials. Typically, she suggests, men would express their political sympathies and public behaviour, while women would highlight their family's political background. Women were better able to make emotional appeals, since it was socially acceptable for them to appear needy. ${ }^{432}$ Aron's examination of patronage letters and personal relationships is a formative influence on this project. While her focus is a history of the American civil service, I am interested in the rhetorical strategies used to debate and request patronage. Politicians, administrators, and job-seekers who were outside the bureaucratic structure all employed this rhetoric. In writing and speaking about the civil service and the appointment process, this rhetoric explained a range of conceptions of how politics should work.

\footnotetext{
${ }^{432}$ Cindy Sondik Aron, Ladies and Gentlemen of the Civil Service: Middle Class Work in Victorian America (Oxford: Oxford University Press, 1987), 98-99, 102.
} 
These were and are more than just letters asking for jobs; they also make links between public service and a range of political issues. ${ }^{433}$ As such, they are rich examples of rhetoric. In his review of Bryan A. Garner's A Dictionary of Modern American Usage, David Foster Wallace effectively summarized the core of a rhetorical approach: "[w]hen I say or write something, there are actually a whole lot of different things I am communicating. The propositional content (i.e. the verbal information I'm trying to convey) is only one part of it. Another part is stuff about me, the communicator. Everyone knows this. ${ }^{, 434}$ In the context of social-intellectual history, Quentin Skinner makes a similar point. To place a writer within a society he recommends that historians "understand what questions a writer is addressing, and what he is doing with the concepts available to him." It is simultaneously necessary "to understand some of his basic intentions in writing, and is thus to elicit what exactly he may have meant by what he said—or failed to say." ${ }^{435}$ Skinner's assumption of a male writer is problematic. He does not investigate the histories of exclusion and of privilege that accompanied the ascendance of early modern European philosophies, such as liberalism, republicanism,

\footnotetext{
${ }^{433}$ Another approach to understanding these letters would be to read them as artifacts of nineteenth-century epistolary culture. William Merrill Decker, for instance, refers to letters that were not designed for publication or even broad circulation "as a marginal literary form," and advocates an approach that explores their literary style, form, and conventions. William Merrill Decker, Epistolary Practices: Letter Writing in America Before Telecommunications (Chapel Hill: University of North Carolina Press, 1998), 20. Another approach could focus on how these letters were received and how they may have been read as appears in John Durham Peters, Speaking into the Air: A History of the Idea of Communication (Chicago: University of Chicago Press, 1999). A range of approaches to epistolary history in the context of immigrant letters appears in Bruce S. Elliott, David A. Gerber, and Suzanne M. Sinke, eds., Letters Across Borders: The Epistolary Practices of International Immigrants (New York: Palgrave MacMillan, 2006). Here, however, it is the rhetoric in nineteenth-century patronage letters that is of primary analytical concern. ${ }^{434}$ David Foster Wallace, "Authority and American Usage," in Consider the Lobster and other Essays (New York: Little, Brown and Company, 2006), 96.

${ }^{435}$ Quentin Skinner, The Foundations of Modern Political Thought, Volume I: The Renaissance (Cambridge: Cambridge University Press, 1978), xiii-xiv. Elsewhere, he elaborates that he is "interested in intentionality not with respect to meanings but with respect to speech acts. I am interested, that is, in trying to recover what may have been the meaning of the act of writing particular texts." Maria Lucia PallaresBurke, The New History: Confessions and Conversation (Cambridge: Polity Press, 2002), 223.
} 
and neo-Romanism. Although patron-client relations were largely relationships between men, the forthcoming chapters will explore some women writers. Skinner's larger point, however, remains instructive. Writers rely on resources to argue their points, and these resources are acquired in and dependent upon their society. The rhetorical turn asks scholars to appreciate these tools, and turn to them for insights into the society in which they operated.

That Skinner calls this a social-intellectual history is significant. In looking at letters asking for appointments, this dissertation shifts its focus from the statements made by politicians to statements made by those seeking to improve their position. As we will see, in some examples they are people who are struggling to support themselves and their families. Regarding the history of philosophy, Richard Rorty calls for historians to stop "skipping-from-peak-to-peak level," and to participate in the "nitty-gritty of intellectual history," where "the distinctions between great and non-great dead philosophers, between clear and borderline cases of 'philosophy,' and between philosophy, literature, politics, religion and social sciences are of less and less importance. ${ }^{, 436}$ Drawing from this, I treat the patronage letters as political rhetoric. What is important is how ordinary language attempted to be effective in its socio-political environment.

Bettina Bradbury also offers a useful frame with which to examine the rhetoric in these letters. Writing about widowed women in Montreal, Bradbury argues that they used a range of strategies to meet their daily challenges. In doing so, she explains that widows pulled together "their own particular patchworks of possibility, framed by their wealth,

\footnotetext{
${ }^{436}$ Richard Rorty, "The Historiography of Philosophy: Four Genres," in Richard Rorty, J.B. Schneewind, and Quentin Skinner, eds., Philosophy in History: Essays on the Historiography of Philosophy (Cambridge: Cambridge University Press, 1984), 70.
} 
their health, their skills, and their family situation." "437 "Patchworks of possibilities" is a useful concept to think with when considering all types of requests for patronage. The following chapters explore ideas about religion, family, communities, reciprocity, service, gender, and friendship. Applicants based their claims on whatever they could, hoping to secure an appointment.

Not all letters in this period were rhetorically rich. For example, one letter to John A. Macdonald simply stated, "I am in favor of the appointment of J.E. Smith as collector here." ${ }^{, 438}$ Another brief letter stated: "My Dear Sir John, You have often told me to write you on the occasion of any vacancy. The collectorship of Toronto is vacant. ${ }^{, 439}$ It is impossible to know why these letters were so brief. They may have reflected that the patron was already familiar with the applicant. They might also suggest the writer did not have much to say. Although this type of letter was common, it was not dominant. As we will see, many letters were more detailed. In these details, we can see popular understanding of Canada's shifting political cultures.

Another aspect that is difficult to know is which of these letters were successful. This question is deliberately avoided in the following chapters. There are two reasons for this. The first is inspired again by Skinner whose histories of philosophies attempted to bracket issues of truth. Rather than asking philosophical questions about what was true, Skinner mapped how people altered their positions, and changed what they held to be true. ${ }^{440}$ In this vein, I do not ask what worked in a patronage letter, but what did the

\footnotetext{
${ }^{437}$ Bettina Bradbury, Wife to Widow: Lives, Laws, and Politics in Nineteenth-Century Montreal (Vancouver: UBC Press, 2011), 328.

${ }^{438}$ Library and Archives Canada (hereafter LAC), John A. Macdonald Fonds, MG26 A, Vol. 300, Sir MC Cameron to Macdonald, 2 March 1868, 137201.

${ }^{439}$ LAC, Macdonald Fonds, vol. 300/1, JB Hurlbert to Macdonald, 28 February 1868, 137189.

${ }^{440}$ Kari Palonen, Quentin Skinner: History, Politics, Rhetoric (Cambridge: Polity Press, 2003), 59-60; Pallares-Burke, The New History, 216.
} 
applicants do and what did they think and hope might work? The second reason is pragmatic. Through attendance books, annual reports, and censuses it may be possible to know which of these applicants were successful. It would still, however, be impossible to know why they were successful - the causes of an appointment are more difficult to reconstruct. Furthermore, even if a request was ignored it still demonstrates how an aspiring civil servant engaged with the period's political culture. Such an approach is further buttressed by the observations of Dominique Marshall in her history of Quebec's welfare state, where she found "[relief] requests that were both accepted by officials and ignored by them." ${ }^{441}$ Even ideas and requests that were rejected contributed to thinking about the civil service. As such they need to be understood historically.

The following chapters are arranged thematically. Chapter Five examines applicants attempting to demonstrate their authority with a reference to a range of communities. Chapter Six focuses on references to the body in patron-client relationships. Chapter Seven turns to sentimental requests. The second half of the nineteenth century was a period when reforms attempted to limit the ways people imagined the civil service. Nevertheless, the letters show how a range of citizens continued to shift and adapt to the conditions of debate. These letters illustrate how processes of state formation were not only debated at elite levels. These processes were located, reproduced, and at times, contested in the society that administrators attempted to govern.

\footnotetext{
${ }^{441}$ Dominique Marshall, The Social Origins of the Welfare State: Québec Families, Compulsory Education, and Family Allowances, 1940-1955, translated by Nicola Doone Danby (Waterloo: Wilfrid Laurier University Press, 2006), xii.
} 


\section{Chapter 5}

\section{Constructing Public Authority: Communities, the Public, and Patronage Networks}

An 1869 letter sent to George-Étienne Cartier, the Conservative Minister of Militia, recommended an applicant for the federal civil service because he was "bien connu pour ses principes religieux et politiques, père d'une jeune et nombreuse famille." ${ }^{442}$ Likewise, an 1888 applicant asked Prime Minister John A. Macdonald to make him the Customs Collector for Goderich, Ontario, because he was the treasurer of the local Conservative Association, and was a "a man of great service in the church.",443 These two letters made reference to a range of associations that were part of establishing a claim. They alluded to both religious and partisan participation. The former also connected the claim to supporting a family. It is impossible to know the sincerity of these associations. It is possible, by treating them as rhetoric, to show how patronage requests and political appointments were related to community concerns. Largely focusing on the outside service - positions away from Ottawa - this chapter explores how popular ideas about public service were articulated, limited, and supported in reference to a wide range of shifting communities.

The concept of community itself is contested. John C. Walsh and Steve High argue against the tautologies of "common sense" understandings, based on shared sociability or municipality. Instead, they call for understanding "community as imagined reality, community as social interaction, and community as process." ${ }^{444}$ They also insist on understanding all elements as critical to understanding the power relations inherent in

\footnotetext{
${ }^{442}$ Library and Archives Canada (hereafter LAC), Sir Georges Etienne Cartier Fonds, MG27 ID4, Aug. Campron to Cartier, 1 May 1869, 346.

${ }^{443}$ LAC, Sir John A. Macdonald Fonds, MG26 A, vol. 320, J Beck to Macdonald, 18 July 1888, 144453.

${ }^{444}$ John C. Walsh and Steve High, "Rethinking the Concept of Community," Histoire sociale/ Social History, 32:64 (1999), 257.
} 
the ongoing processes of (re)creating communities. While Walsh and High stress the politics of community making, the arguments advanced in this chapter demonstrate how community was also a critical context for the political culture of patronage. Marguerite Van Die has similarly argued that changing understandings of religion and community altered constructions about the Victorian family. She notes that, in the second half of the nineteenth-century, a "changing sense of place and time" meant that people would have to integrate "self-identity, family and religion in new ways." 445 From a governmentality perspective, Nikolas Rose makes a similar point. He argues that community is "a moral field binding persons into durable relations. It is a space of emotional relationships through which individual identities are constructed through their bonds to micro-cultures of values and meanings." 446 This chapter outlines how patronage applicants connected their claims to a wide range of community-oriented relationships - the local, the national, the public, the religious, and the familial. Their aspirations to administrative roles were, in many letters, given currency by roles they already played in their everyday lives.

By focusing on a range of individualized and localized understandings of constructions of civil servants and political men, this chapter complements but also departs from the major Canadian literature. Gordon Stewart describes patronage in terms of how patrons manipulated and benefited from patron-client relations. ${ }^{447}$ Noel adds nuance to this approach. He focuses on the mediating role of brokers to connect grand patrons and clients, a practice especially important as clientalist networks expanded in the

\footnotetext{
${ }^{445}$ Marguerite Van Die, Religion, Family and Community in Victorian Canada: The Colbys of Carrollcroft (Montreal and Kingston: McGill-Queen's University Press, 2005), 41.

${ }^{446}$ Nikolas Rose, Powers of Freedom: Reframing Political Thought (Cambridge: Cambridge University Press, 1999), 172. Emphasis in original.

${ }^{447}$ Gordon T. Stewart, The Origins of Canadian Politics: A Comparative Approach (Vancouver: University of British Columbia Press, 1986), 87, 99.
} 
1840s and 1850s. ${ }^{448}$ This work emphasizes the partisan and political elements of these relationships. As we will see, however, these relations were more complicated than partisan or political interests revealed. Although focusing on political effects, Noel notes that patron-client relationships, "were conditioned by customs of the community and the character of the economy in which they are located, but they are invariably personal, face to face and reinforced by other ties, such as those of common religion or ethnicity, or (as in Upper Canada) of common service in the local militia regiment. ${ }^{, 449}$ Building on this insight, I trace how the applicants drew from these relationships. At least in the rhetoric of applicants and politicians, political considerations and personal ambitions were reproduced and reinforced at a range of levels, suggesting a political culture of patronage that was more complex and more participatory than that mapped by Noel and Stewart.

\section{Writing the Local}

An anonymous 1879 letter to John A. Macdonald, the Prime Minister, referred to a recent appointment in the Morrisburgh post office as being of "grave importance," and an issue that was "simply an outrage upon the public, the conservative party of the County of Dundas, and the representative of the County at the Commons. ${ }^{450}$ More precisely, the letter charged that the popular appointment of Mr. Dillen, "a zealous leader of the conservative party in the Country" and a man "highly esteemed by the people generally in Morrisburgh," was overturned by a petition circulated by the "leader of the Grits aided by 3 or 4 disappointed conservatives. ${ }^{, 451}$ Although this was an issue of local partisanship, it highlights the interaction between local issues and electoral parliaments.

\footnotetext{
${ }^{448}$ S.J.R. Noel, Patrons, Clients, Brokers: Ontario Society and Politics, 1791-1896 (Toronto: University of Toronto Press, 1990), 116.

${ }^{449}$ Ibid., 14.

${ }^{450}$ LAC, Macdonald Fonds, vol. 307, Anonymous to Macdonald, 1879, 139905.

${ }^{451}$ Ibid.
} 
1879 was period of bureaucratic realignment, with the Conservatives coming back into power after the election of 1878 . This anonymous letter suggests that these administrative realignments were important throughout the community. In highlighting the importance of local support in the appointment process, this writer also highlighted a different interaction than those typically discussed in patron-client relations. Rather than deferring to the Member of Parliament (MP), this writer suggested that parliament represented the county. This moved political authority to the community, rather than leaving it with the patron.

We have seen that the relationship between politics, the public, and the basis of authority was changing in the second half of the nineteenth century. The rhetoric of democratization that accompanied professionalization emphasized that political power came from "the people". ${ }^{452}$ Letters asking for appointments also suggest that this authority was configured in place. At times, people based their claims on a position in their public roles in their local communities. An 1864 letter to Samuel Leonard Tilley, then New Brunswick's Liberal premier (after 1867, Tilley became a federal Conservative), from J.H. Scott, referenced the different communities with which the writer identified. Asking for the position of Resident Physician at the Saint John General Hospital, Scott explained that "I am a native of St. John, and have graduated in the medical university of New York with honor to my country and to myself. ${ }^{, 453}$ Scott made a connection between his personal success and his community. This implied that his appointment would be popular in Saint John. This last point was reinforced by the fact

\footnotetext{
${ }^{452}$ In the nineteenth century, this class of political citizens was also being redrawn along classed and gendered lines. Allan Greer, The Patriots and the People: The Rebellion of 1837 in Rural Lower Canada (Toronto: University of Toronto Press, 1993), 127.

${ }^{453}$ LAC, Sir Samuel Leonard Tilley Fonds, MG27 ID15, vol. 16, J.H. Scott to Tilley, 5 June 1864.
} 
that he was "solicited by many gentlemen of this city to solicit from you the appointment to that office." ${ }^{454}$ Being urged to apply for a position by others will be taken up in more detail below, but it suggests that his ambition was not only for personal reasons; rather, his appointment would be popular in the municipality of Saint John. Scott referenced other reasons why he should be appointed - his qualifications and experience, and his ability to "conduct the management of the Hospital in as economical a manner" his letter was largely based on the fact that it would be popular in the local community of the city.

The importance of local interests was similarly raised in an 1861 letter to Tilley, recommending John Lloyd as a Justice of the Peace. The letter explained that that "it is the earnest wish of the residents of York Point to have a resident Justice of the Peace in the neighborhood."456 This was a short letter, since Lloyd was "already known to you [Tilley] both personally and politically." ${ }^{, 457}$ The author did not explain his qualifications nor why he would be a popular choice. He did, however, explain that the appointment would satisfy local wishes. Another 1861 letter to Tilley, from James Stevens, illustrated how broad patronage networks considered local concerns. Stevens explained that James Dixon, from Indian Island, NB, applied to him for appointment as Deputy Collector. Before writing to Tilley, Stevens inquired about the applicant, and discovered that "the people of Indian Island very generally recommend him and on enquiry I learn that he is competent to fill the office."458 This highlighted the continued localness of state employees in the expansion of state bureaucracy. As the state apparatus grew politicians

\footnotetext{
454 Ibid.

455 Ibid. This idea of economy was central to the rhetoric of reform and professionalization.

${ }^{456}$ LAC, Tilley Fonds, vol. 9, P. Collins to Tilley, 23 February 1861.

${ }^{457}$ Ibid.

${ }^{458}$ LAC, Tilley Fonds, vol. 10, James G Stevens to Tilley, 16 July 1861.
} 
did not know the people who were seeking appointments. Without a standardized appointment process, personal recommendations were important to speak to an applicant's character. Since it was difficult to manage the growing civil service meeting local expectations was important. Stevens noted that there was another applicant for the position, but he did "not reside in the locality and has no recommendation from Indian Island that I am aware of." ${ }^{459}$ There was no mention of this other applicant's qualifications. That he did not have local support was enough to disqualify him or at the very least portray him in an inferior light in contrast to James Dixon. Promises of local support were one way to buttress a relative lack of information on the applicants.

Appeals to local support were common in letters to Tilley. An 1858 letter supporting John Jordan, from Black River, NB, for a post in the emigration office, stressed that his "clames [sic] on the public is very great." ${ }^{460}$ The writer supported Jordan because of experience and qualifications, adding that since "few men have as much Good news to the county as he," he would be a popular appointment. ${ }^{461}$ The recommendation referred to the circular relationship between individual and public interests. Resulting from his past work Jordan would be popular. At the same time, he was to be considered for a position because of his past work and because his appointment would be popular. An 1869 letter to George-Étienne Cartier, the Conservative Minister of Militia, likewise appealed to public demand, and made connections to larger trade patterns. Louis Renaud sought a harbour-master position for his son. He explained that “[j]'apprends et j'ai vu sur les journaux que les gens de Trois Rivières désirant avoir un maître de Havre, vu

\footnotetext{
${ }^{459}$ Ibid.

${ }^{460}$ LAC, Tilley Fonds, vol.3, Hawkes to Tilley, June 141858.

${ }^{461}$ Ibid.
} 
l'augmentation du shippage de cette ville. ${ }^{, 462}$ Here the relationship between personal and local interests was related to economic and social changes. The harbour-master position was desired to manage and control the increased shipping in the region. Renaud's request for his son was based in the community's economic conditions. This example also shows how patronage interacted with processes of state formation and commercial expansion. ${ }^{463}$ These positions were available because of the state's material expansion. There were more jobs to be filled. At the same time, the requirements to fill these positions were based on constructions of public masculinity. These ideas about state employment existed in public spaces and responded to public demands and changes.

Local demands were also a factor to be managed in the appointment process. This is related to how people asked for jobs, but it reflected the patrons' points of view. Writing to Nova Scotia's Conservative premier, Charles Tupper, H. Binney explained that there "is a jealousy of townships amongst the County." ${ }^{464}$ Referring mostly to School Inspectors, he stressed local interest in appointments. Appointments were partisan concerns, but they were also connected to local demands. As was discussed in Chapter Two, victor-spoils promises continued to be important at least until the 1878 election. That communities were concerned about the allocation of government jobs helps to explain this. These concerns were reproduced at different levels of government. An 1878 letter to Nova Scotia's Provincial Secretary made a similar point. Recommending FN Gisborn as Inspector of Mines, it explained that he was from Greystone, "one of the largest counties in the Province," which was "entitled to some of the important offices,

\footnotetext{
${ }^{462}$ LAC, Cartier Fonds, Louis Renaud to Cartier, 21 April 1869, 272-273.

${ }^{463}$ Timothy Mitchell refers to this process as a the state effect, where the state exists "a material force and as ideological construct." Timothy Mitchell, "Society, Economy and the State Effect" in George Steinmetz, ed., State/Culture: State Formation after the Cultural Turn (Ithaca: Cornell University Press, 1999), 76.

${ }^{464}$ LAC, Sir Charles Tupper Fonds, MG26 F, H. Binney to Tupper, 18 March 1865, 565.
} 
particularly when we can produce qualified men. ${ }^{465}$ This suggests the links between past experience, local support, and political management. Gisborn was recommended because he was qualified, but also because his county was generally underrepresented.

References to local support were made at different levels. A 1900 letter writer to Tupper explained, "I do not feel at liberty to press upon the Hon Hugh John Macdonald [Manitoba's Conservative premier] the claims of any person who is not a resident of Manitoba," since his "patronage is very limited and the claims upon his consideration from parties within the Province will be very numerous. ${ }^{466}$ Although at a provincial level, this shows that managing local needs was part of the process. The limited number of appointments in the region made this management more of an issue. As a solution, the advisor suggested the federal party should seek "to obtain the recommendation of a prominent supporter of Mr. Macdonald from within the Province." ${ }^{, 467}$ Not surprisingly, this relationship between federal and provincial recommendations was also contested. In 1886 John A. Macdonald wrote to William Bain Scarth, a railway promoter and advisor in Winnipeg, to "protest against the Conservative party in Winnipeg, or anywhere else interfering with appointments to office. These are made upon the responsibility of the Government and we must be quite unfettered in our choice." ${ }^{468}$ Despite Macdonald's efforts, this suggests that federal control over patronage was contested. This is line with the Macdonald described by Gordon Stewart, who "[i]nstead of haphazard and personalized methods of rewarding sympathizers and friends... tried to ensure that

\footnotetext{
${ }^{465}$ Provincial Archives of Nova Scotia (hereafter PANS), Provincial Secretary's Papers, RG 7, vol. 84, folder 1, Alex Macdonald to Prov. Secretary, 13 November 1878, 165.

${ }^{466}$ LAC, Tupper Fonds, George F Clark to Tupper, 24 January 1900, 10401.

${ }^{467}$ Ibid.

${ }^{468}$ Archives of Ontario (hereafter AO), William Bain Scarth Fonds, F 67, John A. Macdonald to Scarth, 26 January 1886 .
} 
patronage was given only in return for hard, dedicated work on behalf of the party.",469 That local matters were considered, though, suggests that Macdonald had to negotiate more than just partisanship. He conceded this point to Scarth, noting that, "any suggestions or recommendations of yours I shall be happy to get and will receive and duly consider any recommendation made by our friends as interested Conservatives." ${ }^{, 40}$ Patronage was a popular local issue as well as an administrative one for politicians. For Macdonald controlling patronage was also a way to manage, and at times bend to, local authority. While attempting to maintain his personal control over patronage, Macdonald also accepted local knowledge and recommendations. More complicated than centralized, powerful patrons and localized, grateful clients, job-seeking involved a complicated balance of competing local, partisan, personal and public interests.

\section{Shifting Communities}

The political reorganization of 1867 changed the civil service's size and its organization. Although references to local communities were still important, the federal community involved a wider base. N. Samuels outlined this material expansion to Cartier when he wrote it was "under Confederation that Emigration has become of great notice under Government and as there is no Dominion German Emigrant Agent, I beg of you to get me that appointment. I speak and write the language." ${ }^{471}$ Here he explained new concerns and explained why he was qualified to manage them. The type of knowledge that was required of the ideal civil servant in this period also changed. Samuels notes that he is "acquainted with Canada from Halifax to Sarnia." ${ }^{\text {"47 }}$ Rather than pointing to local

\footnotetext{
${ }^{469}$ Stewart, Origins of Canadian Politics, 67.

${ }^{470}$ AO, Scarth Fonds, John A. Macdonald to Scarth, 9 February 1886.

${ }^{471}$ LAC, Cartier Fonds, N. Samuels to Cartier, 23 April 1869,

472 Ibid.
} 
support or references, here the applicant made his claim, in part, on knowledge of the geography of the new community of Confederation.

On a more practical level, the new order of things and expanded territory created problems in managing the civil service. In the outside service, especially, supervision was increasingly difficult as the head offices were located away from where much of the work was done. W.C. Miller, a New Brunswick advisor to Charles Tupper, wrote to Tupper about the political situation in Saint John in 1879. He stressed, "as a newspaper man and a supporter of yours [I] know better than you precisely can all the currents and eddies of public opinion down here. ${ }^{, 473}$ Again, there was a range of factors at play here. Miller was attempting to secure his position as an advisor to Tupper. He referenced his respectable and public position, and his knowledge of local affairs to show his advice was trustworthy. This note also underscores the difficulty in managing public works at a distance. Regarding some recent dismissals, Miller further noted this difficulty. He wrote that the dismissals may be "justified by reasons of state," but they would still "make bad blood where the government cannot afford to lose friends." ${ }^{474}$ At times, the postConfederation rearrangements created a tension between federal and local interests. Part of managing patronage networks in this period was taking both of these into account.

While this new balancing act sometimes created problems for politicians attempting to dole out positions, it also offered a new, more subtle way of dealing with unhappy reactions to appointments. In 1879, Tupper received a letter criticizing his appointment of a Mr. Bligh as a Shipping Master in Halifax. Tupper responded that he was "very glad to receive the advice of the representatives of the people," but that he was

\footnotetext{
${ }^{473}$ LAC, Tupper Fonds, roll C3203, W.C. Miller to Tupper, 28 November 1879, 2292-2293. Emphasis in original.

${ }^{474}$ Ibid.
} 
also "responsible for every appointment made by the government of which I am a member, not only to the people of N.S. bit of the entire Dominion." ${ }^{475}$ This highlights how patronage communities overlapped and sometimes competed. At times, patronage requests were based in local recommendations. As the civil service expanded and was run from Ottawa, this was no longer necessarily the case. Here Tupper ignored concerns from Halifax. Tupper supported Bligh because "at my request [he] spent a large sum of money contributing to the County of Kings... and from that time he has done all that lay in his power to sustain my cause." ${ }^{476}$

For politicians these flexible and expanded patronage networks offered a polite way to decline or defer requests for appointment. Charles Tupper's letterbook from the late 1890s has several examples of him politely telling applicants from across Canada to write to their local MP. For example, in response to a letter recommending Alex Downay as official reporter for the Exchequer Court of Canada in Ontario, Tupper said he would transfer the letter to the Minister of Justice, who oversaw that appointment. He also suggested that the application would be stronger with a recommendation "from the Members of Parliament representing the City of Toronto."477 This was the type of personal request that civil service reforms were attempting to eliminate in this period. Although this example shows that they did not succeed in that goal, it also shows how the appointment process was becoming more regulated. Tupper was on the verge of becoming prime minister at this time, but he still deferred to local recommendations. It is possible that this expanded and regulated bureaucracy provided Tupper a simple way of shifting an applicant's expectations to someone else, while maintaining good graces. As

\footnotetext{
${ }^{475}$ LAC, Tupper Fonds, Roll C3203, Tupper to MB Daly, 3 February 1789, 2248.

476 Ibid.

${ }^{477}$ LAC, Tupper Fonds, Tupper to R.A. Pyne, 14 April 1896, 7816.
} 
we saw in Chapter Two, regarding Alexander Mackenzie, saying no to patronage requests without offending the applicant was a delicate manner sometimes handled better by some politicians than others. Charles Tupper exploited this new organization when, after the death of the Fishery Inspector from the North-West Territories, he promised support to two different applicants, if they could acquire recommendations from their local Member of Parliament. ${ }^{478}$

\section{Imagining the Public}

Closely related to how patronage requests located in different communities was how applicants frequently made reference to ideas of the public itself. This was another unstable term. As Leonore Davidoff and Catherine Hall argue, constructing demarcations between public and private in the nineteenth century was a process of bourgeois men carving out spaces for themselves to perform their respectability. ${ }^{479}$ Whether appealing to public support or making claims of their own status as public individuals, applicants made connections between their personal interests and those of a larger, imagined community. At times this public referred to a group localized in a municipality or a region. At other times, though, applicants could also refer to a particular subset of a community. It is important to remember that construction of the public was highly gendered. The idea of the public was also used to make reference to the broader, and still changing, political and masculine realm.

This fits with my broader argument that these letters reflected an (admittedly complicated) aspect of liberal governmentalities. On this relationship between the self

\footnotetext{
${ }^{478}$ LAC, Tupper Fonds, Tupper to A Macdonald, 6 April 1896, 7684; Tupper to H Sayer, 6 April 1896, 7685.

${ }^{479}$ Leonore Davidoff and Catherine Hall, Family Fortunes: Men and Women of the English Middle Class, 1780-1850 (New York: Routledge, 1987, 2002), 319,
} 
and the political community in Great Britain, Patrick Joyce writes that the "the self and the social, always existed in relation one to the other in liberalism, though the relationship changed dramatically over time." 480 To take part in nineteenth-century politics and government was to take part "in the real world of the political sphere." the civil service in this relationship, and suggests that it was "conceived as beyond politics." 482 This was also the case in rhetorics of civil service reform in Canada. As we have seen though, the reality was much more complicated. Canada's civil service throughout the second-half of the nineteenth century was based on political and public concerns. In asking for appointments, applicants demonstrated their position with society, and made claims about that position.

An 1858 letter to Tilley, from John Robertson, asking for a post in the railway office opened by highlighting the same kinds of local credentials considered earlier in this chapter. He explained that he had been a resident in Saint John for over thirty-seven years and that he could obtain recommendations from prominent individuals. He further insisted he was "pretty well known to the business community and not altogether a stranger to yourself." 483 By explaining that he was part of the business community Robertson was able to communicate ideas about his character. This community was marked by reason, respectability, and industriousness - all characteristics of a selfgoverned individual. As we have seen, a large part of the rhetoric of professionalizing the civil service was drawn from business language. This appeal indicates, however, that even as patronage was the accepted method of management, business ideas were part of

\footnotetext{
${ }^{480}$ Patrick Joyce, The Rule of Freedom: Liberalism and the Modern City (London: Verso, 2003), 100.

${ }^{481}$ Ibid, 101.

${ }^{482}$ Ibid., 103.

${ }^{483}$ LAC, Tilley Fonds, vol. 4, John Robertson to Tilley, 22 June 1858.
} 
how civil servants were imagined. The business community was also described as one of the groups that monitored and evaluated these appointments. An 1880 letter recommending an applicant for Toronto Port Collectorship promised that he "will be popular both with business men and party men. ${ }^{484}$ Here we can see how closely quotidian politics were linked to commercial interests. Not only were business tropes used to evaluate the civil service, but the business class was one of the interests considered in the appointment process.

The connections between the business, partisan, and public communities were reinforced in an 1889 letter to Macdonald regarding James Domville. Domville was a former Tory MP from New Brunswick, who accused the Liberal party of campaigning on the promise of "to the victors belong the spoils" in the 1878 election. ${ }^{485}$ A petition signed by senators and members of the House of Commons wrote that Domville's financial situation was "so serious that they feel compelled to ask you [Macdonald] to take his case into your consideration and to remember his former services to you and your friends and that you will be pleased to recommend him for some suitable office." ${ }^{486}$ The service they listed included his years in the Conservative party, especially their years in opposition. They went on to link his business career with public work, adding that "[w]hen Mr. Domville was in business and in possession of means to do so he always contributed most cheerfully to all charitable objects. ${ }^{, 487}$ In the eyes of his political supporters

\footnotetext{
${ }^{484}$ LAC, Macdonald Fonds, vol. 310, JJ Foy to Macdonald, 20 September 1880, 140880. Another letter to Macdonald makes a similar point. J Guity recommended CJ Campbell for Toronto Collector of Customs, whom "I find in conversation with business men that [he] would be a favorite." LAC, Macdonald Fonds, vol. 310, J Guity to Macdonald, 30 December 1879, 140834.

${ }^{485}$ Canada, Parliament, Debates of the House of Commons, $4^{\text {th }}$ Parliament, $1^{\text {st }}$ Session, vol. 1 (Ottawa: Citizen Print. and Pub. Co., 1879), 554. This is discussed in Chapter Two. ${ }^{486}$ LAC, Macdonald Fonds, vol. 333, Parliament to Macdonald, 1889, 150590.

${ }^{487}$ Ibid.
} 
Domville deserved help for partisan reasons, but also because he had demonstrated the type of public participation that was expected of respectable public men.

This conflating of business and public interests was stated even more strongly in another letter from Robertson to Tilley. He recognized that there were likely many applicants from the business community because of the general decline in local commerce. While this was bad for business, it was likely positive for Tilley, since "it would enable you to procure the services of a better class of persons on the works than you would if times were good, for I believe there are many in Business now that would be glad if they were clear of it and had a good situation. ${ }^{, 488}$ The business community was literally constructed as 'a better class of persons.' Its members were presumed to be the best type of applicants for public jobs as well as private ones.

In addition to business ideas, Robertson also linked civil service with public opinion. Explaining that he understood that there were several applicants for the railway positions, he was sure Tilley would appoint "those who you think will be the most capable of performing the duties of the office, and would be most likely to give general satisfaction in carrying them out Publickly [sic]. ${ }^{, 489} \mathrm{He}$ also linked being a civil servant with meeting public expectations. ${ }^{490}$ This is slightly more nuanced than the typical descriptions of victor-spoils politics. Rather than simply being a negotiation between patron and client, Robertson understood the appointment process as involving public scrutiny and evaluation. Robertson went on to link pleasing the public with his past

\footnotetext{
${ }^{488}$ LAC, Tilley Fonds, vol. 4, A. Robertson to Tilley, 26 June 1858.

${ }^{489}$ Ibid.

${ }^{490}$ Governmental literature is again helpful in understanding this relationship. Rose refers to "the community-civility game. It involves new conceptions of those who are to be governed, and of the proper relations between the governors and the governed," Powers of Freedom, 188. The back-and-forth surveillance between administrator and the wider public helps regulate these relations. This is also similar to what Joyce identifies as "performing liberalism," Rule of Freedom, 106.
} 
experiences: "as the duties to be performed are all together new to me I would not like to say at once that I could perform them satisfactory, but I have considerable experience in trying to give general satisfaction to the Publick." ${ }^{491}$ This strategy was also used by James Jordan in 1862 when he wrote, "I have no hesitation in saying that I shall feel myself perfectly competent with little practice of performing the duties of both offices to the satisfaction of the government and the traveling public." ${ }^{492}$ This was an interesting tactic, since both statements included the admission that the applicant was not totally qualified for the position. However, since they were generally popular, and understood how to perform publicly, they were suitable candidates.

The interaction between partisan and local concerns was also demonstrated in the 1870 appointment of judges in Nova Scotia. Tupper wrote to Stewart Campbell, the member from Guysborough, NS, explaining that "You are well aware that during the last four months the public mind has been much excited by the strong and constantly reiterated statements of the utterly inefficient state of the Bench in N.S. owing to the advanced age or infirmity of several of the judges." This resulted in the "imperative duty to ignore every consideration but the selection of two gentlemen of the very highest legal attainments and widest experience now in active practice at the bar. ${ }^{, 493}$ In the same letter Tupper asked for a nomination for a census-taker for the region. Ideally, it would be "an

\footnotetext{
${ }^{491}$ LAC, Tilley Fonds, vol. 4, A. Robertson to Tilley, 26 June 1858.

${ }^{492}$ LAC, Tilley Fonds, vol. 12, James Jordan to Tilley, 29 April 1862.

${ }^{493}$ LAC, Tupper Fonds, C3202, Tupper to Stewart Campbell, 28 September 1870. Donald Fyson has written about the appointments of magistrates in Quebec, in a slightly earlier period. Fyson found that to be considered fit to be a magistrate a person had to fit a hierarchy of considerations. The first was to be considered respectable (defined by morality, class, ethnicity, race, age, and temperament). Secondly, a magistrate had to be loyal to Britain. This second point is temporally and geographically contingent. Quebec/Lower Canada was recently conquered in Fyson's period. Finally, the third component for an appointment was competency. Donald Fyson, Magistrates, Police and People: Everyday Criminal Justice in Quebec and Lower Canada, 1764-1837 (Toronto: The Osgoode Society for Canadian Legal History, University of Toronto Press, 2006), 73-88.
} 
able man. He must be well educated and possess a good deal of administrative ability as upon his local management the accuracy of the Census will largely depend."494 Both these comments suggest that qualifications such as experience and efficiency were, at times, part of the considerations for patronage appointments. It also suggests that even under the victor-spoils system, ability and local issues sometimes took precedence over patronage concerns. It was necessary to appoint an experienced and qualified candidate to appease the local population. In this example, we see professionalizing ideas - education, ability, and effective management - as a local issue. The interaction of patronage and reform was not one of parochial attachment to patronage conflicting with centralizing reforms, nor was it as simple as corrupt politicians attempting to maintain the system that entrenched their power. Even as local parties still sought appointments they referred to the ideas of bureaucratic efficiency and reform.

Public opinion was also sometimes referenced as a reason to dismiss an employee. Writing to Tilley from Grand Lake, NB, Richard Robertson claimed that "common report say that the present sheriff must loose [sic] his situation from the many complaints urged by those whom he is employed." ${ }^{, 495}$ Here again local and public opinions were being used as the basis of whether or not someone should keep their position. This was linked to Robertson's own interests, since he assured Tilley that, if given the opportunity, he was "fully competent to assume that responsibility, and to fill that office, to the satisfaction of the Public and credit to myself." ${ }^{, 496}$ More than linking his reputation to public satisfaction, this posited the public as the authority over the position.

\footnotetext{
${ }^{494}$ LAC, Tupper Fonds, C3202, Tupper to Stewart Campbell, 28 September 1870.

495 LAC, Tilley Fonds, Richard Robertson to Tilley, 16 March 1863, 496 Ibid.
} 
Patron-client relationships involved much more than just partisan service. Applicants made their private cases in reference to a range of public issues.

\section{Performing Independence}

As William Kingsford demonstrated in his resistance to Langevin's firing of him, public service positions sometimes involved private concerns. This tension was also demonstrated in letters asking for positions. Often, letters would ask a politician for a job, then explain that they could get references, if needed. Relying on private channels was sometimes a matter of expediency. After a death in the Woodstock, NB Recorder's Office, W.L. Alterton wrote to Tilley, his uncle: "I thought of applying for the office if you consider it advisable and would do what you could for me." He went on to assure Tilley that "[i]f a petition is necessary, I am confident I can obtain any amount of petitioners. ${ }^{, 497}$ In this example it was possibly just easier to go to Tilley first. Nevertheless, it showed a preference to keep his request private, until he had to make it public and gather references.

Sometimes keeping a job request private was explicitly about safeguarding one's reputation. Relying on personal connections was frequently used to circumvent the official route to a position. In his correspondence with John A. Macdonald, D.B. Skelly asked that "the matter [Skelly asking Macdonald for a position] be only known to you and myself." ${ }^{498}$ This was a particularly important for Skelly since his reputation was damaged and his safety threatened after letters describing his activities spying on the Fenians in the 1860s were accidentally made public when Macdonald returned them to

\footnotetext{
${ }^{497}$ LAC, Tilley Fond, vol. 16, W.L. Alterton to Tilley, 11 April 1864.

${ }^{498}$ LAC, Macdonald Fonds, vol. 302, D.B. Skelly to Macdonald, January 10 1872, 137901. He also asked for a 'private letter,' vol.302 D.B. Skelly to T. Ferguson, Macdonald, February 7 1872, 137906; and stressed that he wrote 'several private letters, vol. 302, D.B. Skelly to Macdonald, 10 January 1872, 137900 .
} 
the wrong person. ${ }^{499}$ More generally this reflected the fact that even if common, it still might be personally embarrassing to ask for aid. G.M. Elliott explained this to Macdonald in 1882, explaining that he would like a post in the Napanee Customs Department, "[b]ut I do not wish to injure my influence in the County by applying for it unless there is the good prospect of success." ${ }^{, 500}$ Despite patronage being the accepted method of appointment in this period, there were still concerns about how asking for help might affect one's reputation in the community. In his letter to Tilley, Richard Robertson made this connection with striking clarity. "If necessary I can get a petition numerously and respectably signed," he promised, "but it seems to me degrading to have my name hawked around the country for the sake of a situation in the power of a friend to bestow." ${ }^{501}$ While basing his qualifications in his public appeal, he attempted to keep the issue of his application private. There is some irony in the fact that seeking public support for a public position was seen as degrading. This irony underscores the interaction between private characteristics and public service. It also shows a degree of public satisfaction with a paternalistic political culture. Asking only Tilley was less damaging and degrading than asking the community at large. This irony highlights the performative aspects of class and masculinity in the Victorian era. For these job-seekers, the realities of their independence differed from their public performances. The reward of a position was perhaps worth forfeiting illusions of independence, but without the reward it was a matter best kept private.

${ }^{499}$ LAC, Macdonald Fonds, vol. 302, D.B. Skelly to Macdonald, 10 January 1872, 137900; vol. 489, D.B. Skelly to Macdonald, 13 October 1890, 244624. This gets taken up in more detail in the following chapters. ${ }^{500}$ LAC, Macdonald Fonds, vol. 316, G.M. Tilley to Macdonald, 12 July 1882, 143123. He added, "Neither does Mr. Rae wish to formally apply for it for suitable reasons."

${ }^{501}$ Ibid. 
This tactic was also used in an 1870 letter to Cartier. "Je peux produire des certificats de personnes respectables et ayant de l'influence en la cité de Montréal," Clément Désmarais explained, "si toute fois vous daignez regarder d'un bon œil ma présente application. ${ }^{.502} \mathrm{He}$ did not want to get a petition until he was encouraged to do so by Cartier. Asking for Cartier's support before seeking it from those in his community would have served to strengthen his case. It also allowed him to know there would be a reward if he made his situation and ambitions public. He also distanced himself from his dependence on Cartier's support, explaining that he found himself "dans une position difficile et sans ressources pour subvenir aux besoins de ma mère et de mes jeunes sœurs. ${ }^{, 503}$ This fit with how Marguerite Van Die described many public actions in the Victorian era, as assertions that individuals were "part of an apparently seamless web of family, religion, and community." ${ }^{504}$ Désmarais' request was linked to his family obligations. He sought a position not for his own benefit but those for whom he was responsible. While asking for help he still made sure to describe how he fit the construction of a respectable, and somewhat independent man.

A common tactic to get around this tension between public and private, respectability and dependence, was to stress that others encouraged you to ask for the position. Joseph Giroux explained to Cartier that "à la suggestion de plusieurs de nos amis je prends la liberté de vous écrire de suite à votre arrivée afin de vous demander la place de Landing Waiter. ${ }^{, 505}$ Rhetorically this served two possible functions. First, Giroux based his request in local and public support. Rather than needing help, he was

\footnotetext{
${ }^{502}$ LAC, Cartier Fonds, Clément Désmarais to Cartier, 9 May 1870, 775-776.

${ }^{503}$ Ibid.

${ }^{504}$ Van Die, Religion, Family and Community in Victorian Canada, 147.

${ }^{505}$ LAC, Cartier Fonds, Joseph Giroux to Cartier, 13 April 1869, 200.
} 
responding to his community. Second, it highlighted his political connections to Cartier. Attributing his request to 'nos amis' stressed that they had friends in common. This point was made even more strongly when he wrote that it "[i]nutile de me rappeler à vos souvenirs, et ce que j'ai pu faire pour le parti. ${ }^{, 506}$ More than being popular, then, his request was framed within reciprocal party service. Sliding between public and private, independent and dependent, said and unsaid, Giroux reminded Cartier of his service while expressing he did not have to remind him!

Numerous letters to Tilley made similar points. In 1858, John Jordan wrote he had "been induced at the request of some of the influential friends of the present government to apply for the Emigrant Agency Office.” ${ }^{, 507}$ Similarly, in 1863, George King explained he too had "been requested by a large number of persons in this vicinity to make an application for the appointment of Issuer of Marriage Licences." ${ }^{508}$ Both these letters suggest that the applicants were responding to public opinion, rather than unfortunate circumstances. Patronage networks were somewhat more complicated than simply powerful patrons and needy clients. People seeking jobs stressed their party connections, but they also took pains to show their independence and their local support. Jordan went on to assure Tilley that "it would be difficult to make a more popular appointment than myself." ${ }^{509}$ Although perhaps immodest, this suggests that his public backing would sway Tilley. In 1867, Charles Everett wrote to Tilley and described this relationship between public support and personal interests even more strongly. His interest in the position

\footnotetext{
${ }^{506}$ Ibid, 201. An 1882 letter to Macdonald made a similar, if less ironic, statement. Recommending his son as a customs officer, J. Chamberlain hoped that "his political records is so fresh in your memory to entertain this claim in preference to those who have always stood firm to the one side." LAC, Macdonald Fonds, vol. 316, J Chamberlain to Macdonald, 23 June 1882, 143090.

${ }^{507}$ LAC, Tilley Fonds, vol. 3, John Jordan to Tilley, 3 May 1858.

${ }^{508}$ LAC, Tilley Fonds, vol. 14, George G. King to Tilley, 21 February 1863.

${ }^{509}$ LAC, Tilley Fonds, vol. 3, John Jordan to Tilley, 3 May 1858.
} 
arrived only after "finding my name freely spoken of as a candidate for the postmastership of the City of St. John." ${ }^{510}$ Public interest preceded his private interests or even needs. He then stated he would accept the position, while placing the onus on the patrons. He suggested that "should the Govt having control of the matter think that they could without embarrassment tender the office to me I shall be happy to accept it." ${ }^{511}$ In distancing himself from actually asking for help he was able to underscore his independence, even as he actually asked for the job.

This rhetorical distancing was also shown in an 1890 letter to Macdonald from J.B. Forsyth. He decided to apply for a vacant Collectorship, he said, after "a number of our warm political friends have been good enough to assure me of their assistance if I apply." ${ }^{, 512}$ His application was again based in community support. It was this community that could speak to his qualifications and his party service. Forsyth concluded by connecting his application to the changing administrative context. He suggested it would be better to appoint him rather than simply promoting a clerk to the vacancy. If the latter course was taken "why should not every head clerk be promoted when a vacancy occurs from Halifax to Vancouver?" ${ }^{, 13}$ He presented his request as a solution to an administrative problem. It would be better to appoint him than to set a precedent for internal promotion. 1890 was just prior to the second Royal Commission on the Civil Service. Forsyth was not only connecting his claim to popular support but also to the changing administrative context. Professionalization complicated patronage relations, but

\footnotetext{
${ }^{510}$ LAC, Tilley Fonds, vol. 20, Charles Everett to Tilley, 3 July 1867 . It may be worth noting that 511 Ibid.

${ }^{512}$ LAC, Macdonald Fonds, vol. 335, J.B. Forsyth to Macdonald, 6 January 1890, 151252.

${ }^{513}$ Ibid., 151253.
} 
applicants were sometimes able fit their requests and their personal lives into the new context.

\section{Religion}

The competing and shifting understandings of how patronage should be allocated, and from which communities public authority should derive, was routinely raised in reference to religion. In patronage requests religion acted, at times, as a means of linking people together, but also as a way of isolating different groups. In letters asking for positions, the importance of religion depended on a politician's own beliefs, associations, and the community in general. Religious participation was manipulated and referred to in a variety of ways. Marguerite Van Die argues that, in Victorian Canada, religion structured social experience, in similar ways to "marriage and kinship patterns, moral and legal obligations and expectations, and the allocation of valued resources." ${ }^{514}$ Patronage networks were another structure that governed certain actions in this period. Patronage networks also constituted a structure that interacted with religion in a range of ways and contexts.

Letters from New Brunswick and Nova Scotia that made reference to religion often stressed the need to balance positions between Catholics and Protestants. This was, in turn, linked to maintaining party support. In the lead-up to an 1861 election, a letter to Samuel Tilley from James Cassidy complained that no Catholics in Moncton held an appointment. This situation was "not doing the Catholics justice," since "as long as we support the Liberal [Tilley's] government we should have a small share if we don't get equal." ${ }^{, 515}$ Reciprocal relations, in this view, were connected to denominational concerns.

\footnotetext{
${ }^{514}$ Van Die, Religion, Family and Community in Victorian Canada, 9.

${ }^{515}$ LAC, Tilley Fonds, vol. 9, James Cassidy to Tilley, 14 February 1861.
} 
If Catholics continued to support Tilley and the Liberal Party, they should be rewarded with appointments. Cassidy went on to make his claim in terms of both religion and qualifications, "claim[ing] those offices as a right to me as a Catholic.... every just man in the government will say I have a just claim and a good right to those offices from my hard labour and losses I have sustained." His claim was based on past political service and his hard work, but it was simultaneously framed as an issue of religious equality.

Stressing that he was both hard working and Catholic, Cassidy engaged another debate that shaped appointments in the period: one about the character of Catholics. In 1862, letter writer James Olive reported on the divisions between Protestants and Catholics in the Parish of Lancaster. Olive was concerned that a petition was being circulated to have the district redrawn, and have Catholics - for the most part "persons of an inferior class, ill qualified to govern themselves, much less others" -appointed to the School Board. ${ }^{516}$ If the reorganization passed, he protested, "the respectable portion of the community would be outnumbered and have no voice in the management of their local affairs." As Protestants lost local power, it would be transferred to "a set of ignorant and bigoted persons, having no stake in the parish nor any desire only to further their own selfish interests, would have the ruling powers to the very great detriment of the place. ${ }^{517}$ Religion was connected to who was qualified to take part in politics and in administration. Bureaucratic concerns were, in this instance, voiced through a rhetoric of religious bigotry. This rhetoric was further connected to local parish and district concerns, to a politics of both religion and place.

\footnotetext{
${ }^{516}$ LAC, Tilley Fonds, vol.11, James Olive to Tilley, 14 March 1862. J.R. Miller has identified the tensions between increasingly conservative Catholicism and more liberal Protestant groups in nineteenth-century Canada, especially after the European revolutions of 1848. "Anti-Catholic Thought in Victorian Canada," Canadian Historical Review, 66:4 (1985), 476.

${ }^{517}$ LAC, Tilley Fonds, vol.11, James Olive to Tilley, 14 March 1862.
} 
These localized concerns about religious equality and discrimination were manifested differently from district to district. While James Olive was concerned with Catholics being given too much administrative power, an 1863 letter to one of Tilley's assistants explained that the "Catholics of Portland place confidence in you that you will have the man elected from among their midst who will be his successor. And any thing to the contrary will be a direct insult to that body." 518 The letter referred specifically to positions on the magistracy, which, at the time, had only one Catholic out of thirteen seats. In this example a religious group was transformed into an interest group that needed management. In 1881, James Hogan, a Catholic minister from Montreal, made this point explicitly to Macdonald. ${ }^{519}$ He recommended P. Ryan as customs officer for Montreal, explaining that "as Parish priest for the constituency... I can assure you that in case of his appointment, not only is there no danger of loss to the Government, but that on the contrary, the favor conferred will secure for it additional support." ${ }^{, 520}$ Since he was the parish priest, Hogan could write with authority on both Ryan and on the community. This also suggests that patronage was understood in relation with community support. The interaction between politicians and local administrators was structured by partisan and local interests, but also by religious interests.

Religion was at times presented as a concern to be managed. This fits with the mid-nineteenth century as a period of deepening religious conflict. ${ }^{521}$ It was also,

\footnotetext{
${ }^{518}$ LAC, Tilley Fonds, vol. 14, Robert McCann to Charles Watters, 30 March 1863.

${ }^{519}$ LAC, Census of 1871, Montreal City, St. Anne's Ward, 58.

${ }^{520}$ LAC, Macdonald Fonds, vol. 311, Rev. James Hogan to Macdonald, 20 April 1881, 141419.

521 These conflicts were particularly intense between orange orders and working class catholic groups. In Toronto, this conflict lead to riots, explored in Gregory S. Kealey's chapter "The Orange Order in Toronto: Religious Riots and the Working Class," in his Toronto Workers Respond to Industrial Capitalism, 1867 1892 (Toronto: University of Toronto Press, 1980). For New Brunswick in the 1840s similar tensions appear in Scott W. See, Riots in New Brunswick: Orange Nativism and Social Violence in the 1840s (University of Toronto Press, 1993). The gendered connotations of such violent conflicts between
} 
however, a period of optimism, where many developers and improvers hoped ideas of progress, expansion, and technology would settle these religious tensions. ${ }^{522}$ This same optimism was central to thinking about civil service reforms. In this period of professionalization, religious concerns would, ideally, be removed from the realm of administrative politics. An 1870 letter to Cartier, from James Quinan, the Vicar General from Arichat, expressed this hope that religious differences would be removed from the appointment process. Upon hearing that Nova Scotia was rumoured to receive additional judges on the Supreme Court, Quinan wrote: “Certainly a man's religion is neither a qualification nor a disqualification for a seat on the Bench, and I would be the last person in the world to claim a position, or office, for any man, on the mere ground of religion." After establishing his impartial position, Quinan went on to make a qualification. He explained that "it sometimes happens, notwithstanding, that the claims of a minority are systematically set aside, and an individual of their body properly qualified for such or such an officer, and aspiring to it by the desire of his friends, is ignored, in on other ground than that of his religion, by the intolerance of a bigoted majority. It has been so heretofore in Nova Scotia." ${ }^{523}$ Quinan claimed to be writing on behalf of the 90,000

Protestants and Catholics in Montreal are outlined by Dan Horner in “'Shame on You as Men!': Contesting Authority in the Aftermath of Montreal's Gavazzi Riot, 1853," Histoire sociale/ Social History, vol. 44, no. 87 (2011), 29-52. Political tensions between liberal intellectuals and the ultramontane authorities in Quebec are outlined in Jean-Paul Bernard, Les Rouges: libéralisme, nationalisme et anticléricalisme au milieu du XIXe siècle (Montréal : Les presses de l’Université du Québec, 1971).

${ }_{522}$ Suzanne Zeller, Inventing Canada: Early Victorian Science and the Idea of a Transcontinental Nation (Toronto: University of Toronto Press, 1987), 8. A.A. den Otter similarly views these beliefs as central to ideas of Canadian nationalism. He is ultimately critical of these optimistic Confederation-era politicians and promoters, since they promoted "technological nationalism" which "created a false sense of identity, based not on the ideas and feelings of a people but founded on a disposable commodity. The Philosophy of Railways: The Transcontinental Railway Idea in British North America (Toronto: University of Toronto Press, 1997), 30.

${ }^{523}$ LAC, Cartier Fonds, James Quinan to Cartier, 21 March 1870, 576 
Catholics in Nova Scotia, "who pray that one of the judges to be appointed, be taken from their body, if a properly qualified person can be found among them."

Quinan's appeal highlights the shifting grounds upon which patronage was enacted in this era. The judge should be qualified but also from a particular part of the community. Similarly, Quinan's request was from a minority group but one with a great deal of support and influence. Religion itself should not be considered, except in this situation when it needed to be considered to rectify the bigotry of Canadian political culture. ${ }^{525}$ Quinan was criticizing state practices from his position as a leader in the Nova Scotia's Catholic community. As he advanced this particular cause, he still echoed ideas of the impartial bureaucratic state.

The movement for professionalization of the civil service was designed to shift the electoral issues away from matters of 'ins and outs' regarding government jobs. As we have seen, these reforms had mixed results. Even as the rhetoric of patronage was replaced with one of regulated processes, religion continued to shape interests in the appointment process. In 1878, an electoral year and a year when reforming tropes were becoming entrenched in the mainstream of Canadian political rhetoric, W. Miller wrote to Charles Tupper, then Minister of Public Works, advising him on the minority rights and patronage in Saint John, New Brunswick. Miller reported that John A. Macdonald's treatment of the Roman Catholic minority in the Maritimes was "flagrantly unjust" and "strongly impolite." Despite the fact that "the principle of respecting minorities is respected in other Provinces of the Dominion," Catholics in the Maritimes had been

\footnotetext{
${ }^{524}$ Ibid.

${ }^{525}$ This is an example the expanding cultural language of the state. Processes of state formation set the language through which the state can be criticized and reformed. Philip Corrigan and Derek Sayer, The Great Arch: English State Formation as Cultural Revolution (Oxford: Basil Blackwell, 1985), 164.
} 
"ignored. I might say contemptuously ignored in the most unjustifiable manner. ${ }^{, 526}$ For Miller this was a problem at every level of government, from positions in the federal cabinet to local situations. Maritime Catholics, he insisted, were "ignored in everything. ${ }^{, 527}$ Miller explicitly connected these Catholics with the party's electoral strategies and with partisanship in general. He encouraged Tupper to see if "Sir John...feels himself strong enough just now to treat us even worse than [former Liberal Prime Minister] Mr Mackenzie did, but the latter found out his error, and acknowledged and regrets it when too late, and so many others. ${ }^{, 528}$ Elections in this era were, at least partially, run on how to allocate patronage positions. Mackenzie was unpopular because of his reluctance to rely on victor-spoils ideas. According to Miller, religious tensions amplified these concerns. He concluded with a warning to the Conservative party: "I should be very surprised if the Catholic electorate of the Dominion will be indifferent to our treatment, for its injustice is too palpable not to arrest their attention. ${ }^{.529}$

This sense that Macdonald was hostile to Catholics did not go away. In 1887, The Globe published an attack on Macdonald's appeals to Orangemen in Toronto. As Gregory Kealey has argued, this group had a "profoundly ambiguous heritage" in Toronto in this period. For Protestant workers, the Orange Order aided the struggle to survive in city. At the same time, however, the Order produced tensions with Catholics that sometimes led to riots. ${ }^{530}$ The Globe reported, based on signed declarations and the testimony of Senator John O'Donohoe, that Macdonald planned to "humbug the Orangemen in the Chestnut Park arrangements." At the same time, he was planning to

\footnotetext{
${ }^{526}$ LAC, Tupper Fonds, C3203, W Miller to Tupper, 30 November 1878, 2184

${ }^{527}$ Ibid., 2185. Emphasis in original.

${ }^{528}$ Ibid., 2186.

${ }^{529}$ Ibid., 2188

${ }^{530}$ Kealey, Toronto Workers Respond to Industrial Capitalism, 98.
} 
"humbug the Catholics" while circulating a pamphlet that claimed Catholics "did not get a fair share of the Provincial patronage, that Mr. Mowat and his colleagues treated them unjustly, and therefore that they should raise a sectarian cry and vote for... the Tory Candidates. ${ }^{531}$ This touched on how involved and intimately connected to politics these patronage networks continued to be. The Globe accused Macdonald of using appointments and rumours of injustice as an electoral strategy. This article also showed how the rhetoric of patronage involved managing sectarian and religious tensions. The fact that this was fundamentally a rhetorical strategy is highlighted by the fact that Macdonald was accused of ignoring both Orangemen and Catholics, while still trying to appeal to both these groups. According to the paper "[s]uch modes of humbugging different bodies of people at the same time are not new to Sir John." ${ }^{, 532}$ More than simply giving appointments, patronage was a process of political management.

In 1893, The Globe again referenced the interaction between public service and religion. In this instance, the rhetoric of professionalism was used. In response to a pamphlet that claimed there were more Catholics than Protestants in the civil service, the paper explained that it was "a matter of indifference whether the employees of the Dominion are Catholics, Protestants or disciples of Confucius, Mohammed or Buddha, so long as they do their work well.."533 Tropes of impartiality had replaced the discriminatory ones used earlier. This distanced The Globe from the anti-Catholicism it espoused earlier in the century, under George Brown's editorship. ${ }^{534}$ The newspaper added that the pamphlet was deliberately misleading, since it ignored over half the

${ }^{531}$ The Globe, 19 January 1887, 4.

${ }^{532}$ Ibid.

${ }^{533}$ The Globe, Catholics at Ottawa, December 2 1893, 8.

${ }^{534}$ Miller, "Anti-Catholic Thought in Victorian Canada," 480. 
departments and exaggerated the number of Catholics in the departments it counted. The newspaper concluded that even if the civil service was skewed Catholic, it would not mean Catholics had undue influence. This was related to the restructuring of the civil service and establishing civil servants as impartial. The Globe stated: "We know of no better way of depriving a man of political influence than taking him out of the neighborhood where he is known and sending him to Ottawa to be one of the undistinguished army of civil servants.. ${ }^{, 535}$ This is an interesting stance that reflects the circular logic that governed the changing ideas about society and administration. The Globe claimed that religion did not matter as much as performance in the civil service. At the same time, however, since civil servants did not have much influence, there was no threat of Catholics being given too much power. This was further connected to issues of place and the local. Someone who was influential in a particular community or neighborhood would become less influential when rewarded with a position in and/or from Ottawa.

One interesting way that personal belief was combined with ideas of association and community were the several references to temperance organizations in letters to Samuel Leonard Tilley. At least fourteen writers in Tilley's collection at Library and Archives Canada make connections between temperance and patronage. In comparison, in Cartier's collections, I found only two examples of this; in Tupper's, a single example; and none in Macdonald's. For Cartier, an applicant stated that "I am of perfect sober habits, and energetic in the endeavour to perform to the satisfaction of my superiors." Another letter of reference included sobriety and probity as qualities that recommended

\footnotetext{
${ }^{535}$ The Globe, Catholics at Ottawa, December 2 1893, 8.

${ }^{536}$ LAC, Cartier Fonds, James Brian to Cartier, 6 September 1871, 1367-1368.
} 
the applicant. ${ }^{537}$ Both of these letters position sobriety as a personal characteristic, not as a community interest. ${ }^{538}$

The references to temperance in Tilley's letters are more substantive. T.W. Acheson notes that in New Brunswick evangelical religion was particularly influential, resulting from a cooperation with the Liberal Reform Party, and the successful political careers of three evangelical liberals: Lemuel Allen Wilmot, Samuel Leonard Tilley, and George Edwin King. ${ }^{539}$ Tilley was active in New Brunswick temperance circles, and was a member of the Sons of Temperance. This point was not lost on those seeking his influence and patronage. B.J. Underhill referred to Tilley as his "Dear Brother," and explained he was writing "reluctantly but at the same time feel that I am addressing a friend that will not view it amiss although I do add one more to the already long list of hungry expectants." 540 Another applicant explained he was "comparatively speaking, a stranger to you." He was hopeful for help and willing to write, however, because he had "frequently had the honor of meeting with [you] at session of the...the Sons of Temperance. ${ }^{, 541}$ Both these examples relied on Tilley's participation in the temperance movement (and in a fraternal voluntary association) as the basis for their claim. This points to the interaction between personal activities and public employment. These

\footnotetext{
${ }^{537}$ LAC, Cartier Fonds, Paul Serris to Cartier, n.d., 134.

${ }^{538}$ According to Brian Young's biography of Cartier, temperance was likely not a concern for Cartier, who was generally concerned with economic matters rather than moral ones. Young describes Cartier and his family as "drinkers, dancers, and flirts," - traits that strained their relationship to his wife and her family, who were "strong Catholics." Brian Young, George-Etienne Cartier: Montreal Bourgeois (Kingston and Montreal: McGill-Queen's University Press, 1981), 29. For John A. Macdonald, Ged Martin notes that although his drinking decreased in the last twenty years of his life, throughout the 1870s and 1880s he positioned himself against Liberal policies of intervention, which included temperance legislation. Ged Martin, "John A. Macdonald and the Bottle," Journal of Canadian Studies, 40:3 (2006), 178.

${ }^{539}$ T.W. Acheson, "Evangelicals and Public Life in Southern New Brunswick, 1830-1880, in Marguerite Van Die, ed., Religion and Public Life in Canada: Historical and Comparative Perspectives (Toronto: University of Toronto Press, 2001), 51.

${ }^{540}$ LAC, Tilley Fonds, vol. 2, B.J. Underhill to Tilley, 18 January 1858.

${ }^{541}$ LAC, Tilley Fonds, vol. 10, William Dudley to Tilley, 28 June 1861.
} 
applicants attempted to parlay their voluntary religious service into a public position.

This strategy was particularly appealing in New Brunswick because one of the leading politicians was part of this religious community. The local context was one where appeals to temperance were considered effective strategies.

At times these links between religiosity, temperance, and public work were made even more strongly to Tilley. In a letter of recommendation, John Richely concluded that since "you and he are churchmen, I leave the case with you." ${ }^{, 52}$ Religion, in this instance, was the sole basis the recommendation. It was also considered enough of a link between Tilley and the applicant to create a patronage network. Similarly, another letter explained, "Mr Davidson is a member of our Order, and has labored with considerable success for the past two years in this Province as a temperance Inspector." ${ }^{, 543}$ The applicant's private work for a volunteer association was turned into the basis of his appeal for a civil service position. As in the letter to Cartier above, some applicants writing to Tilley also noted their own temperance as proof of their respectable and moderate character. These appeals were more common in New Brunswick, because of the particular intersection of personal, public and religious activity. Demonstrating one's own temperance and one's involvement with the movement was a rhetorical tactic to appeal to Tilley.

\section{Family}

Family was another private realm referenced in requests for public work. Like ideas of the local and the public, familial spaces were also shifting during the Victorian era. Echoing Davidoff and Hall, John Tosh suggests that the separation of work from

\footnotetext{
${ }^{542}$ LAC, Tilley Fonds, vol. 10, John Richely to Tilley, 5 August 1861.

${ }^{543}$ LAC, Tilley Fonds, vol. 3, C.W. Kingston to Tilley, 11 June 1858.
} 
home was an expectation of middle class masculinity in the Victorian era. ${ }^{544}$ This did not mean, however, that ideas about the family and a man's role within his family were removed from ideas about work. Jeff Hearn argues that in this same era the expansion of state powers eroded those of private patriarchies. This expansion was combined with the "consolidation, and perhaps diffusion, of the patriarchal nuclear family." 545 Even as ideas about public and private were being differentiated, there were overlaps and disjunctions in how these realms were articulated. In patronage requests, Canadian men frequently pointed to their private roles as fathers, husbands, and heads of households. By referencing their dependents, applicants were also able to add an emotional element to their appeal, while qualifying their dependence upon the patron.

One of the earliest letters in Cartier's LAC collection used family obligations as the basis for his request. After apologizing for disturbing Cartier "au milieu de vos nombreuses occupations pour une affaire vraiment personnelle" he explained that "la situation toute particulière où je me trouve ayant à soutenir de vieux parents me forcent de demander aujourd'hui à votre gouvernement ce que je n'ai jamais demandé à aucun ministre. ${ }^{, 546}$ Implicit in the apology was a distinction between personal and public concerns, the latter being a politician's primary interest. The applicant gestured to his independence, stressing that he had never done this before. He only contravened his

\footnotetext{
${ }^{544}$ John Tosh, A Man's Place: Masculinity and the Middle-Class Home in Victorian England (New Haven: Yale University Press, 1999), 17. For Upper Canada in this period, Marguerite Van Die notes that the "male gender construct was on of "marketplace manhood." Van Die, Religion, Family and Community in Victorian Canada, 83. In a working-class context, Bettina Bradbury has argued that this separation, mixed with new coercion to arrive at work on time changed the dynamics of family life. She argues that this separation was overstated, however, since family and religion were important to masculinity as well. Bettina Bradbury, Working Families: Age, Gender and Daily Survival in Industrial Montreal (Toronto: McClelland and Stewart, 1993), 37.

545 Jeff Hearn, Men in the Public Eye: The Construction and Deconstruction of Public Men and Public Patriarchies (London: Routledge, 1992), 114-115.

${ }^{546}$ LAC, Cartier Fonds, Cyrile Boucher to Cartier, 18 July 1856, 17o-17p.
} 
typical behavior because of family obligations - to care for his parents. He went on to explicitly connect these private problems with the public. He explained that "si vous pouviez me donner une place dans une département public voue rendriez à un jeune compatriote un service. ${ }^{, 547}$ In moving from a rhetoric of family to one of a wider community, he was asking as a compatriot. This connected his involvement to the broader imagined community of French Canadians.

This strategy of highlighting family obligations was fairly common. An 1861 letter to Tilley from John Stuart described how he was laid off from his office job, as the office suffered during "hard times." Now, "I have a wife and four children to support and earning nothing, those hard times press heavily upon me." ${ }^{548}$ He positioned himself as a victim of circumstance who otherwise meeting the demands of respectable employment. This letter also stressed the modest nature of the request, asking Tilley only for a post that would "furnish me a bare living." In exchange for consideration, he promised to "keep the favor in lasting remembrance and perhaps the time may arrive that I can be of some service to you." 549 This letter, too, moved from a personal, domestic issue to a wider one of political reciprocity.

Connecting patronage, politics, community improvement, and the family was at times even more explicit. William Boyd asked Tilley for a position that would "enable me to continue for some time longer, the education of my children, who I trust, may become useful in the province, in the classics and the sciences, and to support them and myself just comfortably." ${ }^{, 550}$ As with many examples we have seen in this chapter, this

\footnotetext{
547 Ibid.

${ }^{548}$ LAC, Tilley Fonds, vol.10, John Stuart to Tilley, 11 July 1861.

549 Ibid.

${ }^{550}$ LAC, Tilley Fond, vol.5, William J Boyd to Tilley, 23 February 1859.
} 
removed the onus for the request from the applicant and placed it elsewhere, in this case on his children. Supporting his family would be a public benefit to the whole province. That Boyd suggested classics and science were the key to this education may also be noteworthy. In the Victorian era, science was connected to hope for progress and development. ${ }^{551}$ Daniel Samson has outlined the role social improvement and optimism in the development of liberal government in Nova Scotia in this period. ${ }^{552}$ Boyd's example also suggests that these ideas were related to administrative and family issues. His public position would help him raise his children into good citizens. Ideas of improvement, detailed by Samson and others, were, in this example, applied to a household level. Of course, as Foucault suggested, in a liberal rationality "a person who wishes to govern the state well must first learn how to govern himself, his goods and his patrimony." At the same time, though, when a state is well run "the head of the family will know how to look after his family, his goods and his patrimony."553 Boyd's connection between his position, his family's education, and the community shows the interplay these different levels of liberal governmentality. In an era of scientific improvement, educating your children for public participation was part of practicing good self- and home-management.

\footnotetext{
551 Suzanne Zeller, Inventing Canada, 5.

552 Daniel Samson, The Spirit of Industry and Improvement: Liberal Government and Rural-Industrial Society, Nova Scotia, 1790-1862 (Montreal and Kingston: McGill-Queen's University Press, 2008). E.A. Heaman makes similar points about the role of agricultural exhibits in forming a liberal farming community in Upper Canada/ Ontario, E.A. Heaman, The Inglorious Arts of Peace: Exhibitions in Canadian Society during the Nineteenth Century (Toronto: University of Toronto Press, 1999). Samson's Nova Scotia is much less unified than the public sphere described by Heamon, or by Jeffrey McNairn in The Capacity to Judge: Public Opinion and Deliberative Democracy in Upper Canada, 1791-1854 (Toronto: University of Toronto Press, 2000).

${ }^{553}$ Michel Foucault, "Governmentality," in Graham Burchell, Colin Gordon and Peter Miller, eds., The Foucault Effect: Studies in Governmentality (Chicago: The University of Chicago Press, 1991), 91-92.
} 
H.F.L. Berthelot asked for a civil service position in terms of his family concerns. He flatteringly told Cartier that "[s]i vous me faites entrer au Bureau des Statistiques vous serez un des bienfaiteurs de ma famille qui vous sera très reconnaissante. ${ }^{, 554}$ Berthelot detailed how he was burdened by his parents' debt, adding that his job as a lawyer did not allow him to pay the debt and support his family. He was clear in his request: "je cherche aujourd'hui n'importe quel emploi dans les bureaux du gouvernement afin de gagner de l'argent. " $" 555$ This is a surprisingly frank declaration given the effort most applicants took to show their modest and independent nature. It is also a reminder all these patronage requests involved a material and classed element. For all the performances of social identity - of public masculinity, of independence, of reason, of self-government - in the end these were also material requests.

The family remained a concern in letters about patronage throughout the last decades of the nineteenth-century. In 1869, Thomas McGinn wrote to Cartier "in the earnest and confident hope that some suitable employment may be given to me, whereby I, with my family, may be enabled to eat the bread of honest industry." ${ }^{556}$ He signaled ideas about respectability, hard work and family support - all qualities that would normally mark an independent, public man. Similarly, an 1887 letter to Tupper asked for consideration for a recently opened sheriff position. The position would suit him, he explained because "[w]hen you have eight children, still too young to do anything, a little addition to what farming brings him, in the hard times, is most desirable." ${ }^{.57}$ The

\footnotetext{
${ }^{554}$ LAC, Cartier Fonds, H.F.L. Berthelot to Cartier, 13 March 1865, 18g-18h.

${ }_{555}^{55}$ Ibid.

${ }^{556}$ LAC, Cartier Fonds, Thomas McGinn to Cartier, 20 April 1869, 259.

${ }^{557}$ LAC, Tupper Fonds, vol. 6, H Phipps to Tupper, 25 November 1887, 3642.
} 
reference to "hard times" qualified his request for help, implying normally he could provide for his family.

In some instances family connections were also part of this process. P.H. Attwood wrote to Lord Stanley, the Governor General, in 1889 asking for a position in Manitoba. He hoped that Stanley was "not unmindful of services rendered the Mother Country in the somewhat distant past," because "I am the son of a Waterloo veteran." also described his own military service and usual independence, but attempted to strengthen his claim through his father's service. In 1864, Solomon Powell outlined his family's deep history in New Brunswick. He noted he was "a descendant of the loyalists and our family settled this county as British subjects and who first contributed to make the wilderness fertile planes, that they carried on the whole Mercantile Machinery for years. ${ }^{, 559}$ Amidst the debates over political realignment in 1864 it is possible that an appeal to loyalty, to a wider British community, would have been powerful. More locally, Powell was linking his family's history to that of the county in which he lived. Furthermore, this loyalist history was connected with developing property and commerce, important elements of respectability. An 1867 letter to Cartier made a similar, although less elaborate claim. Walter Blanchard asked for forgiveness in bothering Cartier, but then asked him to "extend the kindness which you have already shown to my father (Louis Blanchard) for whom you obtained a situation in the Inland Revenue Department. ${ }^{, 560}$ It is possible that the applicant was implying his father's service should be rewarded through his son. More generally, this shows how patron-client networks

\footnotetext{
${ }^{558}$ LAC, Macdonald Fonds, vol. 332, P.H. Attwood to Lord Stanley, November 1889, 149965.

${ }_{559}^{5 A C}$, Tilley Fonds, Solomon T. Powell to Tilley, 5 December 1864.

${ }^{560}$ LAC, Cartier Fonds, Walter Blanchard to Cartier, 14 May 1872, 1961.
} 
were rarely limited to the patrons and clients. These relationships reverberated through households, associations, and a range of shifting communities.

Patrons also recognized the importance of family concerns in appointments. In an 1896 response to a letter about Frank Ryan, a printer who would likely be laid off, Tupper explained appointments in simple terms. Discussing the possible lay off of a printer, he noted as the "work began to slacken... a good many men will require to be laid off who are in worse position than he is, inasmuch as some of them have wives and large families of children to support." Tupper promised "[e]verything will be done that is possible to keep him on, but I fear that as a matter of simple justice the lot will have to fall upon him. ${ }^{, 561}$ How to organize letting people go was one of the aspects covered by the civil service reforms of the previous decades. As late as 1896, it was not as simple as quantifiable issues, such seniority or performance, however. Just as Tupper recognized the need to balance appointments with local concerns and issues, and Macdonald and others tried to manage the balance of Catholics and Protestants in the civil service, an employee's family obligations remained a consideration, even in the era of reform. In this same period, Tupper wrote to Langevin about dismissing another printer. He explained that " $[\mathrm{h}]$ is brother and his brother-in-law are kept and this is a single man while the others have families." $" 562$ These two examples suggest that when possible, married men were given preference to single ones. It also suggests that the politics of patronage networks were reproduced at a family level.

\footnotetext{
${ }^{561}$ LAC, Tupper Fonds, Tupper to Rev Cannon McCarthy, 6 April 1896, 7689.

${ }^{562}$ LAC, Tupper Fonds, Tupper to Langevin, 24 April 1896, 8073.
} 
In The Practice of Everyday Life Michel de Certeau comments on the range of factors that connect, separate, and shift partitions between work and leisure. He writes: "sly as a fox and twice as quick: there are countless ways of "making do." ${ }^{963}$ Quotidian practices offered workers paths to resist dominant structures and to find spaces to add their own meaning to these structures. In letters asking for patronage appointments jobseekers reflected this idea of countless tactics to 'make do' and form their "own patchworks of possibilities. ${ }^{, 564}$ In asking for help they articulated a private concern directly to a politician. In this articulation they referenced a multitude of ideas and communities. Their requests were private, but they were formed in the communities they asked to administer and govern. In these rhetorical performances, applicants demonstrated the polysemic understanding of community. They responded to geographic and political concerns with concerns of their own.

These letters also reflected the contradictory impulses of processes of state formation. In parliamentary debates and elections we have seen how politicians attempted to promote reforms while maintaining their own personal and partisan influence. These requests represent related processes. Corrigan and Sayer explain that the cultural revolution of state formation "denotes the terms through which 'the State' may be worshipped, criticized, grasped, reformed, reconstructed, denied, held together, affirmed and carried onwards. ${ }^{, 565}$ Patronage requests and recommendations are another aspect of these languages of the state. Both private and public, independent and asking for help, for personal gain and for the public good, these letters are instances where ordinary

\footnotetext{
${ }^{563}$ Michel de Certeau, The Practice of Everyday Life: Steven Rendall, trans., (Berkeley: University of California Press, 1984), 29.

${ }_{564}$ Bettina Bradbury, Wife to Widow: Lives, Laws, and Politics in Nineteenth-Century Montreal (Vancouver: UBC Press, 2011), 328.

${ }^{565}$ Corrigan and Sayer, The Great Arch, 164-165.
} 
citizens drew from and deployed, tactically, political rhetorics. While drawing on language of state, they also transformed this language through, what Thomas Blom Hanson and Finn Stepputat call, "localized meanings." ${ }^{, 66}$ The gatekeeping efforts of patrons, and later in the century professional bureaucrats, were challenged by these local adaptations.

Whether or not these were successful is less important than what they demonstrate. In Victorian Canada, social and cultural ideas about patronage were made and remade over time and space. Politicians, like job-seekers, responded to and drew from these ideas. Despite their efforts politicians did not have a monopoly on the political culture. These requests for patronage were reflected political changes and local interests, and placed individual concerns within broader, public contests.

\footnotetext{
${ }^{566}$ Thomas Blom Hansen and Finn Stepputat, "Introduction: States of Imagination” in Hanson and Stepputat, eds., States of Imagination: Ethnographic Explorations of the Postcolonial State (Durham: Duke University Press, 2001), 5.
} 


\section{Chapter 6}

\section{The Bureaucratic Body}

In the parliamentary debates preceding civil service reforms, George Elliott Casey proclaimed that men from all parties "seemed to agree that something was wrong in the Civil Service, that some remedy was required, though there was not a universal agreement on the remedy he proposed." ${ }^{567}$ On one level, this was a metaphor that described the problems caused by patronage. For Casey and his allies the civil service was ill; as he said, it needed a "remedy" to heal it. On another level, this reflected a rationality that drew parallels between the body and larger political systems. Just as Casey likened reform as a remedy for the diseased civil service, rhetoric about the civil servants themselves similarly made connections between their bodies, their abilities, their characters, and the public good. ${ }^{568}$

Processes of state formation take place over different scales, periods, and geographies. The body is one of the levels governed by these processes. Michel Foucault reminds us that in bourgeois capitalist societies power is enacted on the body as well as on the consciousness. "In fact," he stresses, "nothing is more material, physical, corporal than the exercise of power." ${ }^{, 569}$ Norbert Elias's survey of the relationship between

\footnotetext{
${ }^{567}$ Canada, Parliament, Debates of the House of Commons, 4th Parliament, 1st Session, 1879, vol. 2 (Ottawa: Citizen Print. and Pub. Co., 1879), 1267.

${ }^{568}$ This fits with a Foucauldian governmentality approach. Foucault refers to upwards and downwards continuity to describe these links between self-government and broader state processes. To be fit to govern others an individual must demonstrate that he can properly and effective govern himself and his household, Michel Foucault, "Governmentality," in Graham Burchell, Colin Gordon and Peter Miller, eds., The Foucault Effect: Studies in Governmentality (Chicago: University of Chicago Press, 1991), 91-92. In Imagining the State, Mark Neocleous also makes a link between the body and understandings of the state. He writes that "one reason why many found the body metaphor a useful way of imagining power and sovereignty lies in the fact that a community imagined in terms of a body appeals because it connotes unity and integration, identity and concord, wholeness and indivisibility. In other words, order." Mark Neocleous, Imagining the State, (Maidenhead: Open University Press, 2003), 14.

${ }_{569}$ Michel Foucault, Power/Knowledge: Selected Interviews and Other Writings, 1972-1977, Colin Gordon, editor (New York: Pantheon Books, 1980), 57-58. Foucault explores how "[t]he classical age discovered
} 
manners and state formation in European history, The Civilizing Process, also makes this point. He argues that the civilizing process resulted in "a real process, a change in the behaviour of the people." ${ }^{570}$ These processes touched on table manners, speech, and led to the "association of sexuality with shame and embarrassment." ${ }^{, 571}$ For Elias, these civilizing processes were related to processes of state formation. By establishing recognized rules, codes, and manners they contributed to the increased regulation of society, engendering a new form of rule. ${ }^{572}$ For this chapter, the important point is that people's bodies were governed by these transformations.

In a disciplinary society, according to Foucault, these embodied power relations are linked to the accumulation of knowledge, in this case knowledge of the body. Foucault highlights military, educational and medical institutions as producing this knowledge. ${ }^{573}$ This relationship between government, the body, and empirical thought is taken up in Nadja Durbach's study of the anti-vaccination movement in mid-nineteenthcentury England, Bodily Matters. She argues that this movement was significant because it "clearly articulated anxieties around the safety of the body and the role of the modern state." 574 The field of statistics was central to these debates, since it collected data on social subjects. The debates about vaccination were about how human bodies worked, and how best to protect them - statistics gave public health policies their support. ${ }^{575}$ In

the body as object and target of power," in Discipline and Punish: The Birth of the Prison, translated by Alan Sheridan (New York: Vintage Books, 1979), 136.

${ }^{570}$ Norbert Elias, The Civilizing Process: Sociogenetic and Psychogenetic Investigations, translated by Edmund Jephcott (London: Blackwell Publishing, 1939, 2000), 85.

${ }^{571}$ Ibid., 151.

572 Ibid., 191, 254.

${ }^{573}$ Foucault, Power/Knowledge, 59.

${ }^{574}$ Nadja Durbach, Bodily Matters: The Anti-Vaccination Movement in England, 1853-1907 (Durham: Duke University Press, 2005), 5-6.

575 There was a Royal Commission to investigate the administration of vaccinations appointed in 1889 . It sat and released reports until 1896. Durbach, Bodily Matters, 10. 
Living Liberalism, Elaine Hadley connects thought about the body to citizenship. She suggests that in Victorian Britain, the liberal subject was an abstraction, "a masked and often disavowed reliance on particular sorts of physical bodies as well as their material and cultural prerogatives. Put bluntly, the white, male body of property and high social standing." ${ }^{576}$ Pamela K. Gilbert makes a similar point in The Citizen's Body: "the social body...included and depends upon a definition of the (ideal) body of the individual citizen. 'Citizenship' is constructed as dependent on the internalization of certain kinds of

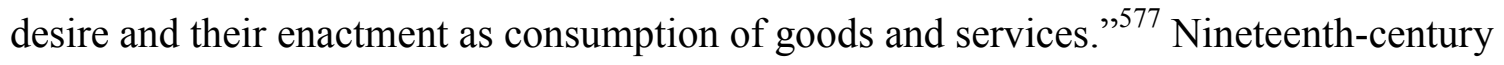
liberalism depended on healthy, white, male bodies that could work, consume, govern themselves and others. ${ }^{578}$ These ideal liberal bodies were the same ones that were assumed to make up Canada's civil service. This, however, was not always the case. Letters asking for public work, as we have seen already, were often based on the declaration of personal qualities and the reminder of social and political connections. One of the personal aspects sometimes described in letters was how an applicant's body or health was connected to their request. Often, in these requests the applicant's body did not fit with how normal bodies were imagined.

This chapter builds on the tension between building a civil service of normalized bodies and job-seekers using particular details about their bodies in their requests. It

\footnotetext{
${ }^{576}$ Elaine Hadley, Living Liberalism: Practical Citizenship in Mid-Victorian Britain (Chicago: The University of Chicago Press, 2010), 12.

${ }^{577}$ Pamela K. Gilbert, The Citizen's Body: Desire, Health, and the Social in Victorian England (Columbus: The Ohio State University Press, 2007), 7.

${ }^{578}$ In a review of Patrick Joyce, The Rule of Freedom: Liberalism and the Modern City (London: Verso, 2003), Chris Otter, The Victorian Eye: A Political History of Light and Vision in Britain, 1800-1910 (Chicago: The University of Chicago Press, 2008), and Stephen Legg, Spaces of Colonialism: Delhi's Urban Governmentalities (Oxford: Blackwell Publishing, 2007), John C. Walsh notes that these liberal subjects also had "[t]he freedom to move, from home, to work, to clubs, to church, to market, to parks." Walsh, "Review of The Rule of Freedom, The Victorian Eye, and Spaces of Colonialism," Urban History Review, 38:1 (2009), 39.
} 
explores how, when, and under what conditions rhetoric about the civil service was also rhetoric about the body. The first part of the chapter looks at how the body was referred to in patronage letters. Generally, these references were to bodies that did not conform to idealized construction. These requests made old age, sickness, and disability part of the request. Demonstrating how a body did not fit the normal construction of a civil servant highlights how uneven and contradictory these things often were. The chapter then moves to rhetoric about the body in civil service legislation. One of the deliberate outcomes of the civil service reforms in the 1880s was that certain types of bodies were removed from the service. The ideal civil servant was constructed with a particular type of body, which was increasingly administered. The official rhetoric about the civil service was one of normalization; in this chapter the focus is on government documents' descriptions of ideal, standard bodies. This was a contrast to the letters about bodies that did, or no longer could, conform to dominant images.

This tension between normalization and individual circumstances addresses alternative constructions of Canadian state formation and of political modernity. Although patronage has been defined as corruption, these types of letters, based on bodily circumstances, underscore why it was relevant to portions of the public. The personal aspect to appointment created a space where particular situations could be manipulated into a claim. Professionalization offered standardized methods of job allocation, but these were based on presumptions about a particular type of character (respectable, efficient, masculine) and a particular type of body (young, healthy, male). Women writing to politicians were able to highlight the fractures in these constructions, at times fitting with the dominant construction, and at other times using constructions of femininity to their 
advantage ${ }^{579}$ In a similar way, writers who referenced non-ideal bodies, whether through age, disease or disability, similarly tried to turn their particular circumstances to their advantage.

\section{The Active Applicant}

Most of the letters asking for government work did not mention the applicant's body. There is, perhaps, something telling in these silences. If a particular type of body was assumed for the civil service, applicants that fit that construction did not need to explain that they fit. Unless otherwise stated, it could be assumed that applicants were healthy, relatively young men. As well, in a system that was based on personal connections, the patron would often know the applicant, so a bodily description was not necessary. An 1888 letter to the Prime Minister, John A. Macdonald, hints that bodily references were usually linked to sickness. J. Murphy, a minister from Ontario, made several recommendations as a result of "the several vacancies here created by deaths or incurable illness." Murphy hoped to find a place in the Customs office for his father and wanted to remind patrons of the "fact that father is in perfect health and has of late ...not lost even a single hours duty through illness.

In other instances, references to the letters asking for patronage did make reference to the applicants' bodies in terms of how they would be well suited to a job often in reference to their youth and energy. One applicant, writing to Samuel Tilley in 1858 made typical connections between his claim and his popular support, as "every gentleman and business person in Fredericton, and in this city know me well." He went on to add a bodily aspect to his claim: "I am of temperate habits, and in the enjoyment of

\footnotetext{
${ }^{579}$ This is taken up again in the next chapter.

${ }^{580}$ Library and Archives Canada (hereafter LAC), Sir John A. Macdonald Fonds, MG26 A, vol. 328, J Murphy to Macdonald, 4 January 1888, 148425.
} 
good health. ${ }^{581}$ Another applicant explained that he wrote because of Tilley's

"willingness to assist all in your power, our young men." Following this, he requested a position in the "many departments under government which require active, honest young men." He added, "and I can procure any number of credentials." 582 Even before there were standardized appointment processes, being a public servant was generally thought of as an occupation for young men. Part of this was related to assumptions about career paths. In addition to being politically connected, and belonging to the party in power, people seeking position were typically constructed as young men that had not yet started their careers. Even though this was not necessarily the reality of the civil service, especially in the mid-nineteenth century, it was still a way to ask for help while fitting within the respectable codes of behavior.

In 1879, Lady Lisgar, widow of the Dominion's second Governor General, made connections between an applicant's body and the expanding state apparatus when she recommended her nephew, Robert Dalton, for a position with the North West Mounted Police. Writing to Tilley, she outlined his connections to her influential family and his qualifications. Dalton was "for five years a clerk in the Merchant's Bank." He wanted to find something else, however, because "the pay is small and the prospects of promotion not bright." ${ }^{583}$ Lady Lisgar was in a powerful position to make this recommendation, and that the wives of politicians were up-to-date on political developments is not surprising. ${ }^{584}$ Lady Lisgar concluded her letter by explaining that he was "a fine, strong,

\footnotetext{
${ }^{581}$ LAC, Sir Samuel Leonard Tilley Fonds, MG27 ID15, vol. 3, James Mount to Tilley, 10 May 1858.

${ }^{582}$ LAC, Tilley Fonds, vol. 12, James P. Craig to Tilley, 27 July 1862.

${ }^{583}$ LAC, Tilley Fonds, vol.21, Lady Lisgar to Tilley, 9 May 1879.

${ }^{584}$ For a slightly earlier period, Bruce Curtis describes the social and political role Lady Durham played Lord Durham's clique's performance of power and authority. Bruce Curtis, "'The Most Splendid Pageant Ever Seen': Grandeur, the Domestic, and Condescension in Lord Durham's Political Theatre," Canadian Historical Review, 89:1 (2008), 59, 65. Katherine M.J. McKenna also explores the political activities of
} 
young fellow 22 yrs old and has been always good and healthy.", 585

Another strategy that relied on the applicant's age was people asking for appointments because in their old age they wanted to take advantage of the reciprocal relationships their service had cultivated. Writing to Nova Scotia's provincial secretary, Andrew Doyle asked to be appointed as a watchman to the new provincial building then being built in Halifax. He was qualified for the position, since he had been a watchman for seventeen years, and always "endeavoured to act faithfully and honestly." ${ }^{, 586} \mathrm{He}$ wanted to guard the new building, he explained because "I am unfitted by age for the performance of more active duty." ${ }^{587}$ While maintaining that he was qualified for the new position he was also explaining why he could no longer fulfill the requirements of other kinds of work. This explanation was related to his body, because of his age.

William Dean wrote to Alexander Campbell, a Conservative Senator and the Postmaster General, in 1872, making similar connections between his age and body, his service, and his connections. "[N]ot being very strong and having a large family to support with very little income," he asked for "benevolent consideration," for a job in the newly built lighthouses. ${ }^{588}$ While this was not a position under Campbell's control, for a job-seeker any extra influence would offer better possibilities for appointment. This was

elite women in A Life of Propriety: Anne Murray Powell and her Family 1755-1849 (Montreal and Kingston: McGill-Queen's University Press, 1994).

${ }^{585}$ LAC, Tilley Fonds, vol.21, Lady Lisgar to Tilley, 9 May 1879. Keith D. Smith has connected processes of state formation to policing the Canadian West in the late 1870s. The North West Mounted Police participated in the processes of "observation and intelligence [that] gathering was to provide a portrait of the progress of colonial rule." This was explicitly racialized since in the West this colonial rule was based on knowing aboriginal people and of constructing oppositions between progressive colonial society and traditional indigenous ones. Keith D. Smith, Liberalism, Surveillance, and Resistance: Indigenous Communities in Western Canada, 1877-1927 (Athabasca: AU Press, 2009), 17.

${ }^{586}$ Provincial Archives of Nova Scotia (hereafter PANS), Provincial Secretary's Papers, RG7, vol. 69, folder 3. Andrew Doyle to Provincial Secretary, 29 June 1867, 264.

${ }_{587}$ Ibid.

${ }^{588}$ Archives of Ontario (hereafter AO), Alexander Campbell Fonds, F23-1, Letter, William Dean, Kingston, to A. Campbell, 15 October 1872, 863. 
also a reminder that the state's material expansion played a role in the daily hopes and plans of the people administered by that expansion. As the Canadian state apparatus was built, there were new jobs that people could seek. The way people thought of these positions and framed their requests were based in their personal, quotidian circumstances. Dean was forty-eight and had five children, between the ages of three and eighteen. ${ }^{589} \mathrm{He}$ had served for twenty-three years in "Her Majesty's Service," and for several "short periods" worked for Campbell. He further deployed the usual tropes in these letters, his "good character," and that he supported the Tory party and John A. Macdonald in Kingston's elections. ${ }^{590}$ More than outlining Dean's service, this letter was noteworthy because it also underscored the embodied element of government work. Resulting from his age, Dean could no longer do the type of labour he had earlier in his life. He felt he was still able, however, to be the caretaker of a lighthouse. Different types of labour required different types of ability, and were experienced differently. Furthermore, his connections to Campbell were based on his age. This suggests that in the patronage system, job-seekers sought to use seemingly non-ideal circumstances to their advantage. Dean's inability to support his family was the result of his body and age - his "not being very strong." While his age weakened his body, it also allowed him to have developed the relationship with his patron that he used to frame his request. ${ }^{591}$

\footnotetext{
${ }^{589}$ LAC, Census of 1871, Province of Ontario, District 66, 49.

${ }^{590}$ AO, Alexander Campbell Fonds, F23-1, Letter, William Dean, Kingston, to A. Campbell, 15 October 1872,863 .

${ }^{591}$ This relationship between age and service was also made in an 1869 letter to George-Etienne Cartier, the Tory Minister of Militia: "je me fais vieux et je me crois qualifié pour cette place." He added that he and Cartier had known each other "de puis années," and Cartier knew that "j'ai eu a souffrir en 37 et 38." Sir George Etienne Cartier Fonds, MG26 ID4, F.M. le Pailleur to Cartier, 28 April 1869, 327-328.
} 


\section{Bodies at Public Work}

More common than appeals for help because of the applicant's age, were those based in reference to general sickness or injury. This dissertation has treated patronage letters as rhetorical performances - of the self, of public activity, and of the applicant's merit. They were attempts by the authors to make links between their personal lives and histories and broader political histories. As they wrote their lives, these applicants sometimes included descriptions of their health as part of their thinking about public work. In the patronage system, these particular circumstances could be transformed into part of the applicant's request.

One such request that made links between personal sickness and a public claim was from Z. Estey to Tilley in 1859. Estey explained that he was "anxious on account of the state of my health." He wanted a position that would give him "an opportunity to have time for exercise after office hours, or that will require my body more or less in the air. ${ }^{, 592}$ Here the regularity that came from office work was linked to his body. By keeping standard hours during the day, Estey would be able to improve his body through exercise. In No Place of Grace, T. Jackson Lears outlined the sense of unease and discomfort that resulted from the excesses of bureaucratic society in the late-nineteenthcentury United States. ${ }^{593}$ Anti-modern culture was a response to this social and moral

\footnotetext{
${ }^{592}$ LAC, Tilley Fonds, vol. 6, Z. Estey to Tilley, 19 August 1859. It is possible that previous to this Estey was a farmer. There are two Z. Estey's listed in the 1851 census of New Brunswick, both farmers. 1851 Census of New Brunswick, York County, Douglas Parish, 12, 35.

${ }^{593}$ T.J. Jackson Lears, No Place of Grace: Antimodernism and the Transformation of American Culture, 1880-1920 (New York: Pantheon Books, 1981). This idea of introducing different air was a major theme in the emerging discourses of occupational health. Carolyn Steedman summarizes the work of nineteenthcentury Doctor, Charles Thackrah. Thackrah "divided 'professional men' and the diseases of their occupations into three types: persons whose mental application was alternated with exercise in fresh air; those who too know exercise at all; and those who lived and worked 'in a bad atmosphere, maintain one position for most of the day, take little exercise and are frequently under the excitement of ambition." Charles Turner Thackrah, The Effects of Arts, Trades and Professions and of Civic States and Habits of
} 
crisis. Writing in an earlier and less bureaucratized period, Estey was outlining a different relationship with bureaucratic work. Regular hours and a less taxing job would have given him the time and energy to exercise his body. This bodily dimension was further directly linked to his claim. "I have been so long sick," he concluded, "that makes me feel deserving of doing something that will not only give me some imployment [sic] but an opportunity to regain my health. ${ }^{, 594}$ This was a fairly circular logic. He deserved a job because he had been sick; and, he wanted a job for exercise to improve his health. This logic, however, helps highlight how personally involved the clients were in patron-client relationships. Whether job-seeking to support a family, or in Estey's case to improve his health, turning to these networks offered opportunities for survival and redemption to those who were disadvantaged.

An applicant's health also was used to explain why they needed help. This fits with the tension common in many of these letters between asking for help while also struggling with the demands of liberal respectability that governed the Victorian era's political culture. This was made explicit in one 1862 letter to Tilley. "I should not trouble you were it not for the unfortunate position in which I find myself placed, with a large helpless family to support and no visible means of doing it," wrote Andrew Scoullar. ${ }^{595}$ We have seen that this was a fairly common technique. ${ }^{596}$ Scoullar's reason for unemployment was slightly different, however. He elaborated: "Owing to my severe illness last winter I was thrown out of employment." ${ }^{597}$ These were circumstances that

Living, on Health and Longevity: with Suggestions for the Removal of the Agents which Produce Disease and Shorten the Duration of Life, $2^{\text {nd }}$ ed., (London: Longman, 1832), 173-92 in Carolyn Steedman, Dust: The Archive and Cultural History (New Brunswick, New Jersey: Rutgers University Press, 2002), 22.

${ }^{594}$ LAC, Tilley Fonds, vol. 6, Z. Estey to Tilley, 19 August 1859.

${ }^{595}$ LAC, Tilley Fonds, vol. 13, Andrew Scoullar to Tilley, 27 August 1862.

${ }^{596}$ Chapter Five explored references to family circumstances as the basis for asking for patronage.

${ }^{597}$ LAC, Tilley Fonds, vol. 13, Andrew Scoullar to Tilley, 27 August 1862. 
were out of his hands; illness placed him in a position that required assistance. He was able to explain away his lack of work, because of his health. Rhetorically, this explanation helped the applicants fit within the liberal political culture based on independence and self-possession. That Scoullar, and others describing their health, did not elaborate on the particulars of their illnesses may also have spoken to his public participation and political connectedness. If his circumstances were well-known, or if he was close with Tilley, they would not require explanation.

Two letters regarding schooling made connections between health and performance more obliquely. Martin Brennan wrote on behalf of his son, Peter. Peter had taught for twelve years, but found "that calling not agreeing with his health." $" 598$ Instead he wanted something "either in Railroad, Customhouse, or any department whist govt has control." 599 John Campbell similarly explained to Tilley that he was unable to perform his duties as school inspector because of his "confinement for some few weeks in the early part to the winter, in consequence of illness." Furthermore, he explained, "I find my duties as Inspector very laborious and expensive." He specified that the travel involved was especially taxing, which was made worse since "my health the past winter has been very much impaired. ${ }^{, 600}$ Instead, he wanted a position that was more local, that would "enable me to remain more at home," and that was better suited to his health. Campbell suggested that a job in the customhouse would satisfy these requirements. ${ }^{601}$ Again there was some rhetorical balancing here. Campbell was explaining why his current job was difficult, while asking for another. His ambition and potential were linked to his body.

\footnotetext{
${ }^{598}$ LAC, Tilley Fonds, vol. 9, Martin C. Brennan to Tilley, 12 September 1860.

599 Ibid.

${ }^{600}$ LAC, Tilley Fonds, vol. 5., John Campbell to Tilley, 20 April 1859.

601 Ibid.
} 
Blaming his failing health for his difficulties to fulfill his responsibilities he was able to place his request within an accepted logic.

Travel was not the only characteristic that made a job physically demanding on the workers. H.H. Morton wrote a letter to the Commissioners, on behalf of the Post Office's Long Room and Dead Letter Branch. The letter complained about the health risks posed by 27 clerks "being obliged to work in a room 24 feet x 49 feet; or practically 24 feet $\mathrm{x} 43$ feet (6 feet being taken up by cupboards)." ${ }^{, 602}$ The crowded workspace was made worse, he continued, "as the lady clerks desire the temperature of the room to be maintained at 70 degrees (it is often much higher) and that the windows remain down, and as the only available door must be kept closed. ${ }^{\prime 603}$ The warm room was filled with dust from emptied newspaper sacks, which in turn rendered "the atmosphere vitiated, and thus a menace to the health of the strongest among us." ${ }^{\circ 04}$ The material work place was connected with sensory experience, health, vitality, and gendered bodies. Morton was addressing an issue of space, essentially requesting a larger office. In doing this, however, he connected the administrative workplace to an issue common in nineteenth factories - that of occupational health. Carolyn Steedman, in Dust, suggests that attention to dust became an increasing concern as more attention was paid to the environmental hazards produced by industrial work. ${ }^{605}$ Eileen Cleere, further notes that by the $1880 \mathrm{~s}$ sanitation required cleanliness, which was "an aesthetic and architectural decision that

\footnotetext{
${ }^{602}$ Canada, Parliament, Sessional Papers of the Dominion of Canada, vol. $11,7^{\text {th }}$ Parliament, $2^{\text {nd }}$ Session (Ottawa: S.E. Dawson, 1892), 16C-424. The physical organization of nineteenth-century factories was also structured according to gendered assumptions. Sonya O. Rose, Limited Livelihoods: Gender and Class in Nineteenth-Century England (Berkeley: University of California Press, 1992), 22.

${ }^{603}$ Parliament, Sessional Papers, 1892, 16C-425.

${ }^{604}$ Ibid.

${ }^{605}$ Steedman, Dust, 19-20; Jacqueline Karnell Corn, Response to Occupational Health Hazards: A Historical Perspective (New York: Van Nostrand Reinhold, 1992).
} 
had converted the ephemera of taste into the science of health." ${ }^{606}$ Administrative thinking drew from industrial and domestic issues. We have seen that how to organize an office, like a factory, was connected to supervision. In this example it was also connected to issues about how to protect the workers' bodies. A delivery clerk from Montreal wrote to Cartier and made concerns over occupational health explicit. "Owing to continual application under a close house atmosphere," he explained, "his health is commencing to show symptoms of failing." He asked for a change of position to "give him the benefit of a change of air." ${ }^{, 67}$ This is a shift from the letters above. The mail clerk was not asking for work because he was sick; he was sick because of his work. The solution to this problem was similar work, with different air.

Civil servants' bodies were affected by more than just the work they did; the spaces they inhabited, they way they moved through their offices, and the documents they kept were all experienced bodily. Moreover, their work was done under the watchful eye of supervisors. For example, in their report to the civil service commissioners in 1881, representatives from the Saving Bank Branch of the Post Office praised the "structural arrangements of the office." These offices were "large enough to allow the clerks to come under the eye of their immediate superior. The result of this arrangement is to promote the efficiency as well as the economy of the service." ${ }^{608}$ This was in line with other disciplinary institutions. Writing about American bureaucracies, John F. Kasson notes that offices, in the late-nineteenth century, became "as hierarchical and

\footnotetext{
606 Eileen Cleere, "Victorian Dust Traps" in William A. Cohen and Ryan Johnson, eds., Filth: Dirt, Disgust, and Modern Life (Minneapolis: University of Minnesota Press, 2005), 130.

${ }^{607}$ LAC, Cartier Fonds, Robert Duncan to Cartier, 3 July 1872, 2176-2177.

${ }^{608}$ Canada, Parliament, Sessional Papers of the Dominion of Canada, Vol. 10, 4th Parliament, $3^{\text {rd }}$ Session. (Ottawa: Maclean, Roger, 1881), 49.
} 
rule-bound as armies.. ${ }^{609}$ The physical arrangement of the workers and workspaces was connected to the quality of public service. This arrangement also literally arranged the workers' bodies in the office in a particular way. ${ }^{610}$ These reports and letters emphasize personal details that were overlooked as a single, all-encompassing set of regulations was placed on the civil service.

\section{Weather and Bodies}

Applicants at times asked for a new position in a new place, because the weather in their current location was not suited to their preferences or their health. For example, an Irish militia member wrote to Tilley in 1862 , explaining that he was considering moving to New Brunswick and applying to its militia. After a visit there, the applicant realized that "this cold wet climate [in Ireland] does not suit, and I found it much benefit from my last visit there." ${ }^{\prime 11}$ This was not explicitly about his health, but it was about how he physically experienced the environment in which he worked. Especially before the reforms of the 1880s and 1890s, these letters were often about how an applicant might be suited for a particular type of work. This letter is a reminder that, at times, where that work was done was part of this consideration.

\footnotetext{
${ }^{609}$ John F. Kasson, Houdini, Tarzan, and the Perfect Man: The White Male Body and the Challenge of Modernity in America, (New York: Hill and Wang, 2001), 11.

${ }^{610}$ In Discipline and Punish: The Birth of the Prison, Alan Sheridan, trans (New York: Vintage Books, 1979), Michel Foucault highlights how supervision and spatial organization were central to disciplinary power. He writes, "in organizing 'cells', 'places' and 'ranks'. The disciplines create spaces that are at once architectural, functional, and hierarchical...they mark places and indicate values; they guarantee the obedience of individuals, but also a better economy of time and gesture." Organizing offices so that they the supervisor could monitor the employees is one such organization. (148). In Colonising Egypt (Berkeley: University of California Press, 1988), Timothy Mitchell explores the use of spatial organization in colonial projects: "rural Egypt was to become, like the classroom and the city, a place wherever possible of continuous control, of tickets and registration papers, of policing and inspection" (97).

${ }^{611}$ LAC, Tilley Fonds, vol. 13, Henry J. Robinson to Tilley, 18 September 1862. Another letter to Tilley also expressed an interest in spending time in New Brunswick, although for slightly different reasons. James Brown, from Charlotte County, NB, explained that he had spent "thirty three winters in Fredericton," and that he "would like very much to make my yearly visit." To help pay for this trip, he asked if there was any public service work for "two or three weeks during the coming session." LAC, Tilley Fonds, vol. 13, James Brown to Tilley, 18 January 1863.
} 
Not everyone was so praising of the weather in New Brunswick. D.B. Skelly, a Tory party member from Ontario, complained that John A. Macdonald had left him "out in the cold. ${ }^{, 612}$ Skelly had contributed his own money to a conservative election campaign in the early 1870 s, at Macdonald's request. He expected a position as a pubic engineer in return. This did not play out as he imagined. Although his complaint was metaphorical, it did take on literal aspect. The only job he was offered was as a labourer on the railway in New Brunswick. One of Macdonald's advisors wrote that "he was sent away the winter and suffered in health and in pocket. ${ }^{, 613}$ In traveling from Ontario to New Brunswick in the winter, Skelly became sick. The cold that he accused Macdonald of leaving him in was a literal one, related to the seasons, in addition to the metaphorical lack of loyalty and reciprocity. That he was only offered a job in New Brunswick was made worse by the fact that "very many civil servants have died lately in Ontario." $\mathrm{He}$ added, "Their deaths have profited me nothing as yet." ${ }^{.614}$ Just as health and fitness were sometimes part of the applicants' claims, they could also be part of the circumstances in which those claims were made. Civil servants' health was relevant to those seeking positions as well as to those administering the appointment process.

Geography and weather were related to the health and the circumstances of the public workers that took jobs. Skelly preferred to stay in Ontario, rather than go to New Brunswick. Arthur Andy, whose mother wrote to Cartier on his behalf, also experienced health issues after traveling for a public position. According to Mrs. Andy's letters, Arthur's health was "precarious," resulting in his being "idle" and with "no prospects of

\footnotetext{
${ }^{612}$ LAC, Macdonald Fonds, MG26 A, vol. 359, Skelly to Macdonald, 6 June 1879, 165704.

${ }^{613}$ LAC, Macdonald Fonds, vol. 302, F. Smith to Macdonald, 8 October 1873, 137949.

${ }^{614}$ LAC, Macdonald Fonds, vol. 357 Skelly to Macdonald, April 141879
} 
getting employment, unless through some kind interference." ${ }^{, 615}$ In the spring of 1871 , Arthur left Quebec for Manitoba, where "he took seriously ill...with inflammation of the lungs." On the advice of "the Indian men" he returned to Quebec, because the "climate was too severe." 616 Again, the applicant's body and its interaction with the spaces in which it worked was part of the claim asking for help. Arthur Andy needed help because his health failed him, not because of a lack of ambition or effort.

A Montreal detective wrote to Cartier in 1870 and made a similar link between work, health and climate. He explained that his health "n'a pas résister dans ce climat, aux mille misères, aux quelles un détective est exposé nuit et jour." ${ }^{617}$ He was clear that he did not want a better paying job, but just something "plus analogues à mes forces."618 In earlier chapters we saw rhetoric from politicians treating civil servants as resources. Here, this same managerial rhetoric was applied by a civil servant to his own body. Knowing what you were capable of, and in what circumstances you could best work was part of the representation of the self. It was based on personal characteristics, but these characteristics were managed, and could be administered rationally. Furthermore, in this case, the personal forces were not only related to the worker's character or ability, but to the geography of the work. Whether as a detective or something less physically demanding, these letters suggest that this work was understood in bodily terms.

\section{Disability and Reciprocity}

In their letters asking for jobs, applicants linked their personal histories to the political context. In that they were lived histories, these histories were embodied. At

\footnotetext{
${ }^{615}$ LAC, Cartier Fonds, Mrs. E. Andy to Cartier, 12 May 1870, 786.

${ }^{616}$ LAC, Cartier Fonds, Mrs. E. Andy to Cartier, 9 January 1872, 1518-1519.

${ }^{617}$ LAC, Cartier Fonds, Vincent Lafon to Cartier, 13 June 1870, 927.

${ }^{618}$ Ibid.
} 
times, the applicant's body itself became part of this history of work, service and reciprocity. Some letters from job-seekers outlined injuries obtained while doing government work. These injuries created special circumstances that required assistance from those in power. They were also written about as being part of the past service, a physical manifestation of experience and reciprocity.

Didymus Cameron, a twenty-two year old sailor, wrote to Tilley in 1859, on the advice of his friends. He was working at a port in Saint John, when he lost three fingers "in the discharge of duty." This loss was "a great blight" to him. ${ }^{619}$ He asked for the consideration of the House, for a small sum, $£ 25$, or "any situation in the next appointment." ${ }^{\text {620 }}$ This was also the strategy used by James Smith, who claimed he "worked harder than my constitution would bear, consequently I have contracted a complaint or infirmity in my back, that renders me almost unfit for hard work." As such, he wanted "some lighter occupation." ${ }^{621}$ Smith suggested that running the new lighthouse, built on the Island of Grand Manan, would be something his body could withstand. Rhetorically, these are different approaches than the previous examples. We have looked at letter writers who explained lack of work because of sickness. In the cases of Cameron and Smith, like the mail clerk previously discussed, the injuries resulted from work. As we will see, in this era, sickness was, to a degree, related to character. This was less of a concern for those injured on the job. Although their bodies were weakened, this was from work they did, not a general weakness. Cameron made this link between his body and his character more directly. "I flatter myself as a son of temperance...possessed

\footnotetext{
${ }^{619}$ LAC, Tilley Fonds, vol. 5, Didymus Cameron to Tilley, 22 February 1859.

${ }^{620}$ Ibid.

${ }^{621}$ LAC, Tilley Fonds, vol. 5, James N. Smith to Tilley, 25 March 1859.
} 
of sturdy habits," he added. ${ }^{622}$ Unlike someone who was sick, this suggests he maintained control over his body. ${ }^{623}$ This control was linked to his reason and his self-possession the same characteristics that made him a good worker and citizen.

Arthur Mondou made this link between his case, his body and his past service to Cartier in terms of public service and the public good. "Sachant que vous avez a cœur l'avancement de Montréal, et surtout Montréal Est," he asked for a job as a copyist, bookkeeper, or "toutes situations analogues." ${ }^{624}$ He was essentially asking for a desk-job, because he could no longer do more physical work after losing his left arm working on the Grand Trunk Railway (GTR). Given Cartier's own interest in the GTR's fortunes, there may have been some networking here. Working for the GTR contributed to Cartier's and to Montreal's success. Because he was injured doing this work he was able to hope that Cartier "aurez pitié d'un orphelin" while maintaining that "Dieu merci je n'ai pas peur de l'ouvrage." ${ }^{\prime 625}$ This underscores the tensions that run through these letters. His circumstances allowed him to ask for pity - an emotional request that was at odds with codes of rationality, respectability, and masculinity. ${ }^{626}$ Although his body was no longer able to do a particular type of work, he was still suited to work in a record-keeping capacity.

Mondou asked Cartier for a job that was less physical than his previous one. P. Delaney made a request framed in similar terms, about his service and his body, but asked for a position that would provide a "long and complete abstention from reading," to

\footnotetext{
${ }^{622}$ LAC, Tilley Fonds, vol. 5, Didymus Cameron to Tilley, 22 February 1859.

${ }^{623}$ Jarrett Rudy, The Freedom to Smoke: Tobacco, Consumption and Identity (Montreal and Kingston: McGill-Queen's University Press, 2005), 5-6. Cheryl Krasnick Warsh, ed., Drink in Canada: Historical Essays (Montreal and Kingston: McGill-Queen's University Press, 1993).

${ }^{624}$ LAC, Cartier Fonds, Arthur H. Mondou to Cartier, 20 July 1872, 2238.

625 Ibid.

${ }^{626}$ The next chapter will further explore the emotive elements of many patronage requests.
} 
preserve his eyes "and give them a chance of restoration." ${ }^{.627} \quad$ Delaney's eyes were "failing," and he could no longer perform his job as editor of the Journal of Education. He suggested that working in the customhouse would let him rest his eyes, and there was a vacancy "through the death of Mr. Haçon. ${ }^{, 628}$ His letter differentiated between the type of work he could do ("anything at figures") and what he could not. It also highlighted that different types of work involved workers' bodies in different ways.

Based on the above examples there seemed to be different ways of asking for a position depending on different situations. Some of these requests involved age, sickness or injury. In participating in patronage networks, these applicants were able to turn their disadvantages into part of their request. That they weren't healthy or able-bodied was used to explain their dependence. Rhetorically, this allowed them to write themselves into a liberal political culture, based on self-possession. It also reminds us that even though civil service work involved a different type of physicality than other types of labour, it was still experienced at a bodily level.

\section{Standardizing Bodies}

The official and political rhetoric about the civil service also contained bodily elements. Whereas letters were framed in terms of exceptional bodies, this rhetoric focused on establishing a standard type of body for public work. Starting with the quickly put together 1868 Civil Service Act, the official documents concerning the civil service

\footnotetext{
${ }^{627}$ LAC, Cartier Fonds, P. Delaney to Cartier, 17 April 1869, 230. In the context of the antebellum American South, Peter John Brownlee has written on the debates over how to best protect eyes overused in urbanizing settings. This was a period when doctors, reformers, eye-specialists, and their public "established standards and practices concerning the properties and maintenance of eyes that delineated ways of seeing particular to this time and place." Peter John Brownlee, "Ophthalmology, Popular Physiology, and the Market Revolution in Vision, 1800-1850," Journal of the Early Republic 28: 4 (2008), 598. He goes onto to note that in this period specialists began examining and considering the eye's "economy" (608).

${ }^{628}$ LAC, Cartier Fonds, P. Delaney to Cartier, 17 April 1869, 230.
} 
took applicants' bodies into consideration. The candidate's age was one consideration. To receive an appointment, the candidate had to be between eighteen and twenty-five, unless they had special considerations or the support of a department head. ${ }^{629}$ Every candidate needed to provide evidence "as the Governor may think sufficient to his age, health, and moral character." ${ }^{630}$ One of the Civil Service Board's earliest duties was to monitor and keep track of this evidence and evaluate the quality of the candidates. The physical and moral characteristics were supported through testimonials from influential members of the applicants' communities. The examiners were also charged with evaluating the candidates to make sure they met the moral and bodily requirements. The Act left the methods of this examination to the Board's discretion. ${ }^{631}$

The 1868 Civil Service Act made links between moral and physical character. This was vaguely defined, but that the two were thought of side-by-side and evidenced in the same testimonials reflects that they were interrelated. This relationship between the body and the character was important to Victorian colonial culture. Mary-Ellen Kelm has written on how Canadian colonization acted upon the bodies of First Nations' people. Notions of European superiority were reinforced through arguments about aboriginal sickness. This process was supported by only collecting medical data that "only served to confirm preconceived ideas" about how First Nations were "naturally or inevitably diseased." ${ }^{632}$ Studies on India's colonial administration have also explored this relationship in detail. In an essay on corruption and political modernity, Dipesh

\footnotetext{
${ }^{629}$ Canada, Parliament, Statutes of Canada, $1{ }^{\text {st }}$ Session, $1{ }^{\text {st }}$ Parliament, (Ottawa: Malcolm Cameron, 1868), 42. ${ }^{630}$ Ibid., 43.

${ }^{631}$ Ibid., 48.

${ }^{632}$ Mary-Ellen Kelm, Colonizing Bodies: Aboriginal Health and Healing in British Columbia, 1900-50 (Vancouver: UBC Press,) 1998, 15.
} 
Chakrabarty explores how the British introduced the idea that the body and character were linked. He argues that the British used "the semiotics of the body" to reflect the relationships of colonial rule. This was a relationship that was based on racial superiority. When this was combined with the material body, "the British conflated character and physical strength, claiming to have an excess in both, unlike Indians." ${ }^{\prime 633}$ The majority of Canadian civil service history was less oppositional than India's. Especially in the Inside Service, where reforms were taken more seriously, administrators were generally the same race and ethnicity as those they oversaw. At times, however, racialized notions of the body were expressed in patronage letters, especially dealing with the West. A.A. Taché, the Archbishop of Manitoba, recommended Angus McKay as an Indian Agent for Manitoba. He made a list of qualifications that included the respect McKay commanded from the community, his knowledge of the law and the population. This list also included that "he is sober, industrial, strictly honest, and has a long experience of life. He is besides of a commanding appearance." ${ }^{334}$ These qualities were connected. His character could be read in his appearance. McKay was presented in a manner similar to William Kingsford and the other public men explored in Chapter Five. There was one key difference, identified by Taché: "[he] has Indian in his blood." ${ }^{635}$ This was an advantage, according to Taché, because he knew the region and the different languages used by those he would monitor. His abilities were connected to his appearance and to his ancestry; both were embodied. Mrinalini Sinha reminds us that these constructions about

\footnotetext{
${ }^{633}$ Dipesh Chakrabarty, Habitations of Modernity: Essays in the Wake of Subaltern Studies (Chicago: University of Chicago Press, 2007), 55. Chakrabarty makes links between the introduction of physical training in India and this logic of domination. He writes, "the whole history of modern physical training in India is rooted in the nationalist construction of modern imperial rule as an experience in direct physical humiliation. The body was, thus, central to the projection of European political strength in India" (56).

${ }^{634}$ LAC, Macdonald Fonds, vol. 327, A.A. Taché to Macdonald, 4 June 1888, 147899.

${ }^{635}$ Ibid.
} 
strength and morality were also gendered. She argues that in the late-nineteenth century colonial administration in India was built on assumptions about British masculinity and Bengali effeminacy. Colonialism worked because Indians were described as feminine, and consequently lacking independence, reason, and strength. ${ }^{636}$

The reforms of 1881-1882 made the bodily requirements more explicit and defined. ${ }^{637}$ The requirements for age and character remained the same as in 1868 . Regarding the body, the commissioners were more precise. They suggested that an applicant must be "free from any physical defect or disease which would be likely to interfere with the proper discharge of his duty." ${ }^{, 638}$ They also prescribed practices to safeguard the service from any of these "defective" bodies.

This logic was combined with that supporting a competitive examination. The Rules and Regulations of the Board of Civil Service Examiners, approved by the Governor General in 1882, set preliminary qualifications that examiners had to make sure candidates fit. The first was making sure the candidate was at least eighteen years old. The second was that "he is free from any physical defect or disease which would likely interfere with the proper discharge of his duties." The third condition was that "his

\footnotetext{
${ }^{636}$ Mrinalini Sinha, Colonial Masculinity: The 'Manly Englishman' and the 'Effeminate Bengali' in the Late Nineteenth Century (Manchester: Manchester University Press 1995), 7, 20.

${ }^{637}$ There is some evidence of politicians discussing the bodily aspects of public work before this. In 1878 , Tupper brought the House's attention to the case of Mr. Boggs, a dismissed train dispatcher from Truro, Nova Scotia. Boggs had caused an accident by giving "mistaken orders... while he was unfitted to discharge his duties in consequence of over-work." "637 "Tupper defended Boggs, referring to the renowned London medical journal, the Lancet - "the highest authority, perhaps, in the world upon this point" suggesting that it was the railway's fault for overworking the dispatcher. In this case, Tupper concluded "eight years good service [by Boggs] should not be forgotten because of fifty-nine hours of straight work." This indicates that this type of work was bodily. Boggs's attention was strained because he was tired from overwork. Canada, Parliament, Debates of the House of Commons, $3^{\text {rd }}$ Parliament, $5^{\text {th }}$ Session (Ottawa: Maclean, Roger, 1878), 1574. The link between the body and the actual work was made again in 1879 as George Casey motivated for reforms. Before an appointment was made, he wanted a measure for the government to ensure that "the young man was capable of discharging the duties which would be imposed upon him, and that he was honest and had the physical ability to withstand the strain of the work he had to do." Parliament, Debates, 1879, 1267.

${ }^{638}$ Parliament, Sessional Papers, 1881, 18.
} 
character is such as to qualify him for employment in the civil service. ${ }^{, 639}$ For all three qualifications the examiners deferred to established authority. Proof of age was checked in the Birth Registry. A practicing physician provided the evidence of health, while a "Minister of religion" wrote the testimonial of character. ${ }^{640}$ Character and the body were combined in the thinking about the competitive examinations. In their 1882 report, the commissioners suggested that an examination "supplemented by proper guarantees as to age, health and moral character...is the most just and practical means of supplying fit persons for the appointment...[and] it will give the best servants to the public." ${ }^{641}$ This is a democratic rhetoric. It is about public service, efficiency, and merit. It is also rhetoric, however, based on assuming an ideal body for the civil servant. Applicants that did not meet the linked physical and moral standards were deemed unsuitable.

This was stressed even more strongly when the commissioners suggested that the new system would be "open to the public instead of being.... a close corporation in the hands of politicians." This open system was not open to all people equally, however. Following the commissioners' recommendations, "opportunity would be given to all intelligent and educated young men to obtain by their merits alone, a start in a service, in which promotion by a continuance of intelligent self-improvement and well-directed labor, would be certain. ${ }^{, 42}$ Even as the commissioners wrote about open opportunities in the civil service, they were (re)making it as a space exclusively for young, healthy men. A British periodical in 1888 went so far as to suggest that the Civil Service examination should have a certain number of marks for health. This would act "an inducement to

\footnotetext{
${ }^{639}$ Canada, Board of Civil Service Examiners, Rules and Regulations of the Board of Civil Service Examiners (Ottawa: The Board, 1882), 4.

${ }^{640}$ Ibid.

${ }^{641}$ Ibid., 20.

${ }^{642}$ Ibid.
} 
schoolmasters and others to pay attention to. ${ }^{.643}$ In this editorial, they particularly meant the dangers of over-work that might be caused by applicants cramming too much before the exam. Regardless of the cause of the sickness, this suggests that civil servants' bodies were being increasingly scrutinized and administered. This follows the trend explored in Part One of this dissertation. The reforms to the civil service were promoted as being more democratic, more equitable, and more open. At the same time they were also more exclusionary in certain regards. As the civil service became more standardized the ideal civil servant became more clearly constructed as a healthy, educated young man. Connected to the narrowing of who was accepted as a suitable candidate, there was no provision for how women's bodies should be examined and evaluated. This follows with that fact that there was no parliamentary debate over women's employment in the service, and their being limited to the lowest class of clerk. Although the service's lowest class was technically opened to women, the regulatory apparatus that accompanied civil service reforms did not make space for female workers.

The age limits on the civil servants were related to how they would progress through departmental ranks. This too was deeply gendered since women were limited to third class, often temporary, positions with no chance of advancement. The senior clerk, however, "would necessarily be a man of mature years." ${ }^{444}$ They also suggested a process to make sure that this progress would be controlled: "men in the lowest grade should have to advance to the head of the next higher class, without interruption or hindrance, excepting misconduct." ${ }^{645}$ Similarly, promotions to the First Class should only be made when there was a vacancy, so as to limit the number of senior clerks. Although it was

${ }^{643}$ E. Ray Lankester, "Competitide [sic] Examination," The Universal Review (November 1888), 391.

${ }^{644}$ Parliament, Sessional Papers, 1881, 334.

${ }^{645}$ Ibid. 
important that men be of an advanced age when they reached the senior positions, it was also important that they not be too old. The upper limit on entering the service was designed to regulate this. The Commissioners also suggested civil servants retire and be superannuated at sixty-five, since "we think there are few positions in which a man of 65 cannot be well replaced by one younger. ${ }^{, 646}$ Replacing older workers with young ones abided with ideas about cost-efficiency. Resulting from the structure of annual pay increases, an older worker would likely earn more than a young or recently appointed one. More generally, this further reflected the increasing precision in the how the civil servant was constructed. It not just a place for men, but it became a particular type of man, in a particular age bracket.

Histories of middle and old age in the Victorian era have noted the prejudices faced by the elderly in the labour force. In her comparative study of age-reporting in Canadian and American censuses, Lisa Dillon describes the use of age-rounding and misreporting. There were a range of reasons for doing so, including uncertainty and vanity. Another cause for this misreporting was that "workers who faced age-based prejudices in the labour market may have found special incentives to underreport their age. ${ }^{, 647}$ Younger workers were thought to be faster, more innovative, and more comfortable with technology. Likewise, Margaret Morganroth Gullette has written on the social construction of aging. She suggests that from 1880, with the start of second industrial revolution, age competition was made systematic among working men. Industrial capitalism, she argues, "began to show that it wanted the younger more than

\footnotetext{
${ }^{646}$ Ibid., 335.

${ }^{647}$ Lisa Dillon, The Shady Side of Fifty: Age and Old Age in Late Victorian Canada and the United States (Montreal and Kingston: McGill-Queen's University Press, 2008), 119. Dillon draws on William Graebner's A History of Retirement: The Meaning and Function of an American Institution 1885-1978 (New Haven: Yale University Press, 1980).
} 
the older, whether the young body in the office or factory system, or the young mind in all organizations." ${ }^{648}$ As Canada's civil service was organized along the same lines as the commercial sector, this same age bias was instituted in public service. The construction of the ideal civil servant included assumptions about age, health, and gender.

The commissioners were relatively neutral in their language about age and the body, generally relying on a democratic rhetoric of efficiency and openness. The administrators interviewed in their report were more direct in their explanations about the relationships between the body and the character in the civil service. The commissioners frequently asked, "[h]ave you any employs in your office, who, from age, infirmity, bad habits, or other cause are unfit for office?" ${ }^{649}$ The Deputy Postmaster General, W.H. Griffin, worried that the strongest characters and bodies would generally prefer to work in the private sector. Even if the service offered superannuation and pay competitive to clerks in private business, he believed "[y]oung men of energy would rather take their chances in the business world." ${ }^{650}$ When asked if "the Civil Service has been looked upon as a refuge for people, who by reason of their indolence or lack of intelligence, could not succeed in other employment," Griffin responded: "to a considerable extent that is the case." $" 651$

A memorandum on the Post Office sent to the commissioners and included in their report further made these connections between character and body in the quality of the candidates. The memo detailed thirty-five "bad appointments." These appointments

\footnotetext{
${ }^{648}$ Margaret Morganroth Gullette, "Midlife Discourses in the Twentieth-Century United States: An Essay on the Sexuality, Ideology, and Politics of 'Middle-Ageism"' in Richard A. Shweder, ed., Welcome to Middle Age and Other Cultural Fictions (Chicago: The University of Chicago Press, 2004), 23.

${ }^{649}$ Parliament, Sessional Papers, 1881, 146.

${ }^{650}$ Ibid., 65.

${ }^{651}$ Ibid.
} 
included thirteen who were dishonest, nine drunkards, two who were too engaged in politics, and ten who "were utterly unfit for duty, being wanting in judgment and activity," and one "who had never learned the letters of the alphabet."(!) This list outlines the antitheses of a good civil servant. The bad included those who were immoderate, partisan, irrational, illiterate, and inactive. Discussion of another "bad appointment" made the link between morality and health more strongly. There was a letter carrier who suffered from epilepsy, and "during his fits, whilst on duty as letter-carrier, the correspondence entrusted him for delivery was, of course, left at the mercy of the public." ${ }^{652}$ These non-ideal appointees were lacking in moral, mental, emotional, and physical strength. Being a drunkard was a failure of character. It was connected to a lack of reason, and the inability to be moderate - that is to say, it was a failure of selfgovernment. The effects of drunkenness, however, are bodily. Similarly, having epilepsy made an employee a bad appointment. Perceived sicknesses were conflated together with a lack of reason, a lack of professionalism and a lack of knowledge.

This understanding of what constituted an unfit employee was not new, or unique to the Post Office. In an 1859 letter to Tilley, Oliver Arnold compared himself to another applicant. He referred to his competition's "indolent habits," that you "may judge from his appearance. ${ }^{\prime 653}$ Oliver suggested that you could read an applicant's habits and character from his appearance. In this logic, one's physical body was a presentation of less tangible characteristics. As in many colonial efforts, the link between the body and character was a strain of thought that was codified in this period. ${ }^{654}$ While writing about

\footnotetext{
652 Ibid., 135.

${ }^{653}$ LAC, Tilley Fonds, vol. 7. Oliver T. Arnold to Tilley, 10 October 1859.

${ }^{654}$ Kelm, Colonizing Bodies. 15. Pamela K. Gilbert connects individual bodies and morality to political affairs: "moral health was understood as coterminous with physical health; political normalcy was
} 
Nova Scotia's post office, Arnold extended this logic to public work in general. "[I]t would no doubt be pleasing to all particularly concerned," he continued, "to have the Buildings Reps in an neat and smug manner." ${ }^{\prime 65}$ This was for a bureaucratic position, but the applicant's body was under scrutiny. It could be read and evaluated against the imagined model of the civil servant. This model shaped how civil servants should act, but also how they should look.

In 1882, while debating civil service reforms, Edward Blake, the Liberal Party's leader, made a similar point. He listed two categories of "improper persons" in the civil service. The first was "men who, from want of education or strength of constitutional or general unfitness, have not and will never become efficient public servants." This relied on the rhetoric of efficiency common in these debates. Blake also made connections between physical and mental ability. Lack of strength was compared to lack of education, but made an applicant unfit and inefficient. The second category was caused by the retention "of men who by old age, incapacity, bad habits or continued idleness, become unavailable for useful purpose." ${ }^{965}$ The Globe echoed this in an 1887 article about superannuation. Referencing the commercial bias against aging workers, the paper warned that in a patronage system, "there is constant danger of the older Civil servants whose political influence has perished by lapse of time, and whose places are wanted for partisans who have rendered valuable service." ${ }^{957}$ Although less overt than Blake's

dependent on this healthy state," The Citizen's Body, 6. This etching of morality onto bodies could also be displayed. As Paige Raibmon suggests imperialist assumptions about aboriginal bodies were also broadcast consuming audience at world fairs and when tourists watched Aboriginal hop pickers work. Authentic Indians: Episodes of Encounter from the Late-Nineteenth-Century Northwest Coast (Durham: Duke University Press, 2005), 34-49, 116-134.

${ }^{655}$ LAC, Tilley Fonds, vol. 7, Oliver T. Arnold to Tilley, 10 October 1859.

${ }^{656}$ Canada, Parliament, Debates of the House of Commons, 4th Parliament, 4th Session (Ottawa: Maclean, Roger, 1882), 791.

${ }^{657}$ The Globe, "Superannuation," 6 January 1887, 4. 
statement, this relied on the link between old age and inefficiency. Providing a pension for older employees would offer a way to remove them, without leaving them with some "some means of protection against poverty in old age or in continued ill-health, and even of providing for the widows and children." ${ }^{658}$ The paper actually expressed mixedfeelings about this, arguing that while it was mostly favourable, it might also overburden the taxpayers. Despite grappling the fiscal realities of a public pension, this statement, like Blake's, reflected the increasingly technical view of the civil service. Employees were imagined as resources to be managed according to political economic principles, rather than personal characteristics. In this technical view the worker's body was still a consideration. Old age and "incapacity" were no longer related to loyalty and experience, but rather were linked with poor performance and inefficiency.

Matters of health were less of a concern to the Royal Commission of 1891-1892. The commissioners did make some suggestions, though, to increase the formalization of bureaucratic procedures. They recommended that whenever an employee took sick leave they should provide a medical certificate. Following general trends in professionalization, they added that a note from any doctor "good standing of an authorized medical association should be accepted. ${ }^{, 659}$ At least rhetorically, this was less about the connections between morality and physicality, and more about the everyday management of the civil service. This management reflected the governmentalization of the civil service. By the 1890s, Canadian administrators were more monitored, their processes more regulated, and their activities more documented than before. This governmentalization slowly replaced the logics of morality, reciprocity, and personality

\footnotetext{
${ }^{658}$ Ibid.

${ }^{659}$ Parliament, Sessional Papers, 1892, 16C-xxiv. Alvin Finkel, Social Policy and Practice in Canada: A History (Wilfrid Laurier Press, 2006), 79.
} 
with one of technicality. Even as the civil service became more technical, however, the civil servant's body was still a consideration. The extent to which it was considered differed according to the "nature of the office and the responsibility connected therewith." This was because different offices would lead to different amounts of "wear and tear upon the official's system," and would consequently require, at times, different "extent of leave given." ${ }^{660}$ Extending sick leave was about managing the civil service. Even in the more technical rhetoric used at the end of the century this reflected the embodied nature of this type of work and management. Here the contradictions of processes of state formation were brought to light. Older tropes about morality were replaced with ones about democracy and efficiency. This new rhetoric, however, still drew from the relationship about body and character. The older logic and order was still influential, even a more technical one was replacing it.

The reforms to Canada's civil service echo somewhat Philip Corrigan's suggestion that "from the start alphebetization and numeration are systems of empowerment/ disembodiment. ${ }^{, 661}$ In attempting to implement standard appointment procedures they standardized the type of body in the civil service. Letters referring to exceptional circumstances and sick, ageing, or injured bodies decreased after these reforms. This was championed as a victory of democratic progress. These standardizations were the remedies that the civil service required. It was remade as a healthier, more able public service. Despite the narrative of progress, this was a false dichotomy. It narrowed the type of person who could enter the civil service. Young,

\footnotetext{
${ }^{660}$ Parliament, Sessional Papers, 1892, 16C-162.

${ }^{661}$ Philip Corrigan, Social Forms/ Human Capacities: Essays in Authority and Difference (London: Routledge, 1990), 188.
} 
healthy men were given more privileges in this standardization. They were increasingly marked as standard. This standardization was in relationship with the society more generally. In Administering Civil Society, Mark Neocleous writes that "'the state does not simply regulate civil society, it actively shapes it according to necessary ends. ${ }^{\prime 662}$ The late-nineteenth century was a period of industrial, technical, and bureaucratic modernization and of professionalization. This ostensibly remade society as more efficient and productive. It also remade it as a society where certain bodies were privileged with access to space, work, and respectability.

Part of the power of these reforms is their bodily dimensions were fairly silent. In adopting rhetorics of efficiency and progress, these state practices were presented as natural and benign. The exclusionary aspects of standardization were never drawn out. There was general agreement about what type of person and what type of body was preferred in the civil service. While powerful, these silences also highlight the contradictory elements of state formation. The rhetoric of democratic improvement was used to marginalize a range of applicants. Letters asking for patronage articulated a range of experiences that did not fit the dominant constructions. This brought out specific understandings of public work that were elided in the abstractions of standardization.

\footnotetext{
${ }^{662}$ Mark Neocleous, Administering Civil Society: Towards a Theory of State Power (London: Macmillan
} Press, 1996), 4. Emphasis in original. 


\section{Chapter 7}

\section{Desiring a Position: Emotions and Patronage}

Bartleby had been a subordinate in the Dead Letter Office at Washington, from which he had been suddenly removed by a change in the administration. When I think over this rumor, hardly can I express the emotions which seize me. Dead letters! does it not sound like dead men?....Ah, Bartleby! Ah, Humanity!

Bartleby the Scrivener, Herman Melville, $1853^{663}$

"Being desirous of obtaining an appointment, I beg your good office for this object." ${ }^{664}$ So stated an 1867 letter to Samuel Leonard Tilley, New Brunswick’s premier and leading Confederation promoter, asking for a junior clerkship. This framing was common in letters requesting patronage appointments. On one level these writers were simply stating that they would like a certain appointment. Desiring a position, however, was different that stating that you were qualified or deserving of that position. Even when used without reflection, these expressions of desire suggest that the rational language of professionalization coexisted with references and appeals to emotions.

Earlier chapters have explained the growing focus on rationality in this period, and yet patronage letters remained saturated in emotion. Why was this so? What might we learn about political culture, about state formation, and about a Canadian state in formation if we take seriously the emotional histories of patronage? It is impossible to know what applicants genuinely meant and felt in these letters. By viewing them as rhetorical performances, however, it is possible to treat them as representations of the applicants' lives, contexts, and concerns. Emotional appeals during this era of bureaucratic professionalization and rationalization demonstrate the ongoing and

\footnotetext{
${ }^{663}$ Herman Melville, "Bartleby the Scrivener: A Story of Wall Street," in Warner Berthoff, ed., Great Short Works of Herman Melville (New York: Perennial Classics, 2004), 73-74.

${ }^{664}$ Library and Archives Canada (hereafter LAC), Sir Samuel Leonard Tilley Fonds, MG27 ID15, vol. 19, Thomas Mack to Tilley, 2 March 1867.
} 
sometimes contradictory interaction of the personal and the political, the intimate and the professional, within Canadian political culture.

George E. Marcus's The Sentimental Citizen calls for an examination of the role of emotion in American politics. He re-conceives reason and emotion as complementary and connected forces that should be considered in tandem. Drawing from neuroscience and psychology, Marcus's thesis goes further still arguing that "people are able to be rational because they are emotional; emotions enable rationality." ${ }^{, 655}$ Emotional responses, according to Marcus, are central to how an individual interprets a political event or ideal. Making a space for emotions in politics is a welcome complication of the traditional view of rational discussion in the public sphere. However, Marcus's approach fails to consider that rationality is itself a contested and changing social historical construction. ${ }^{666}$ Instead, he argues that by better understanding the role of emotions (such as affection, loyalty, fear, and loathing) in politics, people can better engage in political action and debate. In doing so, he repeats the traditional narrative of improving and rationalizing politics, albeit in interesting ways.

The reliance on neuroscience also leads Marcus to explain what people experience in a fairly rigid, deterministic manner. He writes, "[e]motion processes, processes that precede conscious awareness, shape what we pay attention to and how we pay attention." ${ }^{667}$ Nicole Eustace's monograph The Passion is the Gale provides a way out of this epistemological assumption. Examining the period leading to the American

\footnotetext{
${ }^{665}$ George E. Marcus, The Sentimental Citizen: Emotion in Democratic Politics (University Park, PA: Pennsylvania State University Press, 2002), 7.

${ }^{666}$ These historical transformations of rationalities in relation to politics and government are the explored in Michel Foucault's lectures on governmentalities. Especially, in Security, Territory, Population: Lectures at the Collège de France, 1977-1978, Michel Senellart, ed., Graham Burchell, trans. (New York: Palgrave Macmillan, 2004).

${ }^{667}$ Marcus, The Sentimental Citizen, 60.
} 
Revolution, Eustace focuses on the use of emotion in political tracts and personal correspondence. She differentiates between the "internal experience of emotion" and "the external expression of emotion through language. ${ }^{.668}$ Like Eustace, I want to focus on the latter. It is impossible to know what an individual letter writer felt, thought, or experienced from such a documentary fragment. All that is knowable is what that individual wrote or said, and to place such expressions in a cultural context. Whether expressing anxiety over social standing or gratitude to a politician these expressions were contributing to political rhetoric that drew from both professionalization and personal/partisan concerns. ${ }^{669}$ In writing their lives, these applicants were also writing a conception of the Canadian state. Even as professional/rational ideas became the espoused norm, emotional language and personal connections continued to be a crucial part of political language.

Based on letters to Canadian politicians from the late 1850 s to the late 1890 s, this chapter explores expressions of emotions in patronage requests and locates them in their relevant contexts. It begins by exploring letters that bridged the private and the public, by making intimate details the basis for a public position. The chapter then moves to expressions of partisanship and party loyalty. A section follows on how power relations were recreated, and at times, subverted in these letters. Appeals to a politician's

\footnotetext{
${ }^{668}$ Nicole Eustace, Passion is the Gale: Emotion, Power, and the Coming of the American Revolution (Chapel Hill: University of North Carolina Press, 2008), 12. This book is a study of eighteenth-century Pennsylvania, and argues expressions of emotions reflected class relationships and served as an element to negotiate and contest status.

${ }^{669}$ Norbert Elias, Essays III: On Sociology and the Humanities, edited by Richard Kilminster and Stephen Mennell (Dublin: University College Dublin Press, 2009), 140. Similarly, in The Civilizing Process, Elias underscores the relationship between self-government, emotions, and state formation. He writes: "The civilizing of conduct and the corresponding transformation of the structure of mental and emotional life cannot be understood without tracing the process of state-formation." Norbert Elias, The Civilizing Process: Sociogenetic and Psychogenetic Investigations, translated by Edmund Jephcott (London: Blackwell Publishing, 1939, 2000), 191.
} 
friendship and favor were political, although often based on personal loyalty and kindness. The chapter ends with a discussion of metaphors of political violence in patronage requests.

\section{Intimate Appeals}

The letters asking for patronage appointments combined the writers' public and private lives. As they described their lives, writers often revealed intimate information and expressed their concerns and ambitions in emotive language. In an 1858 letter, R.S. Bennison wrote to Tilley and made a connection between familial responsibilities and professional anxiety. He "despaire[d] of a situation being offered.... Were it not for my family, it would not be so disheartening. ${ }^{, 670}$ As was argued in Chapter Five, basing an appeal on family obligations was a common strategy, but Bennison's letter was noteworthy for its expressions of emotions - his despair and anxiety. Again in 1859 Bennison provided another impassioned description of his stressful circumstances and political frustrations. Regarding his inability to procure a situation, Bennison declared that "I am disgusted with them, all that I could do I have done. It has been brought to the notion of both governments." The failure to obtain an appointment led Bennison to consider moving to the United States to find work. He described his financial situation as being particularly dire: "in debt for my rent, with an invalid wife, who has lost the sight of one of her eyes... the loss of sight occasioned no doubt for want of medical advice which I have been and still am unable to procure for her." 671

\footnotetext{
${ }^{670}$ LAC, Tilley Fonds, vol. 4, R.S. Bennison to Tilley, 26 November 1858. Bennison wrote eight long letters asking for support and patronage from Tilley, from 1858 to 1862. In addition to asking for favors, he asks for support for his curriculum to teach music, and proposes a national penmanship

${ }^{671}$ LAC, Tilley Fonds, vol. 6, R.S. Bennison to Tilley, 12 August 1859.
} 
The stress that this placed on Bennison was revealed both in the content and the form of his letters. (See Figures 7.1 and 7.2) Taking aim at New Brunswick's dominant patronage networks he stated:

Were I a fool, no doubt, there would be some opening for me, or were I a reformed drunkard I should enlist the sympathy of the leading temperance men. But as it is now, I must patiently sit and sing 'Home, Home,' see strangers in places of employment while I am thrust out and basined from my family; and temperance men could care very little whether I became a drunkard, a maniac or a suicide. Were either to happen to me, many who now give me the cold shoulder would exclaim 'poor fellow! Who would have thought it?'672

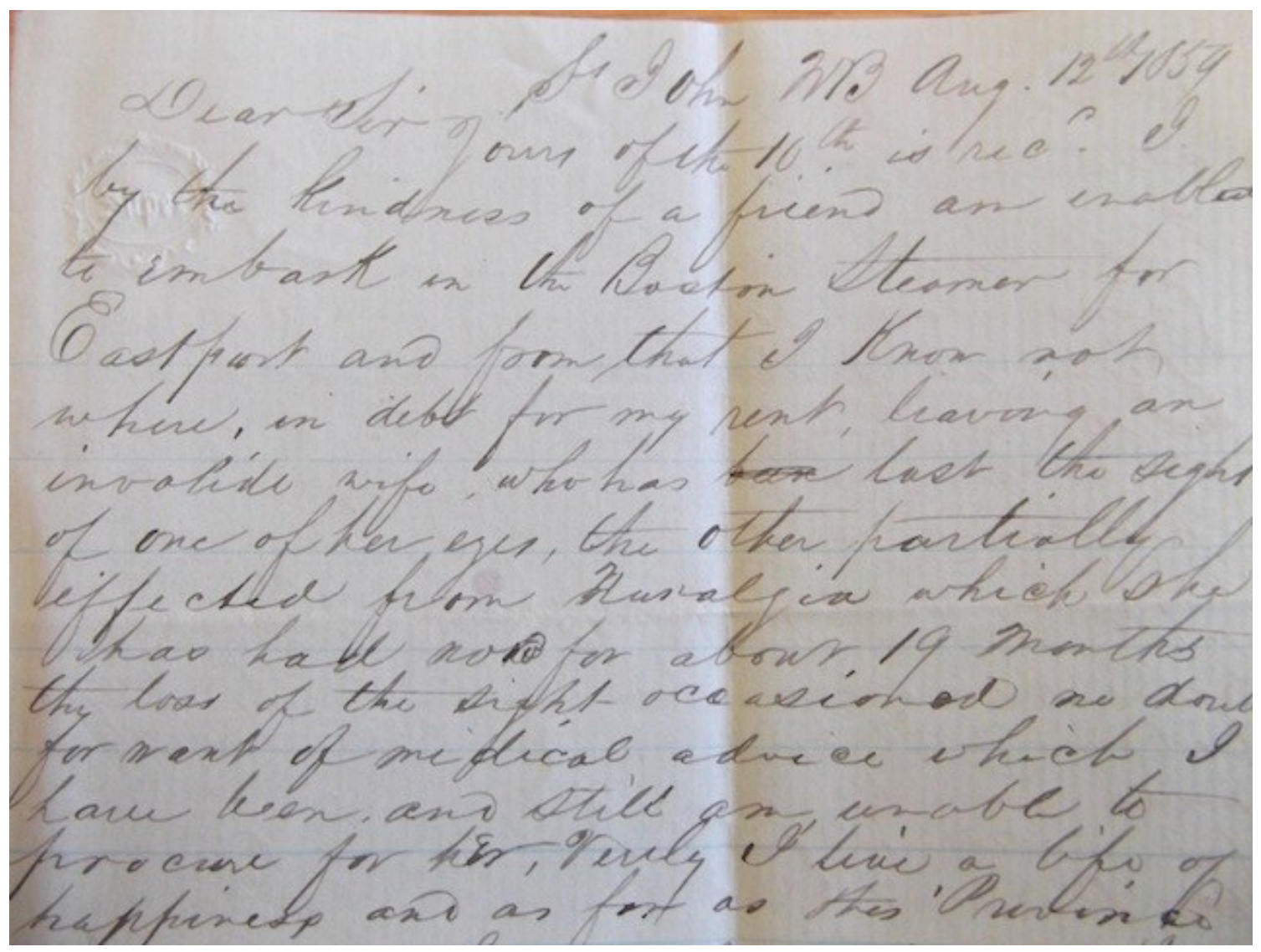

Figure 7. 1. Handwriting Sample. LAC, Tilley Fonds, vol. 6, R.S. Bennison to Tilley, 12 August 1859.

672 Ibid. 


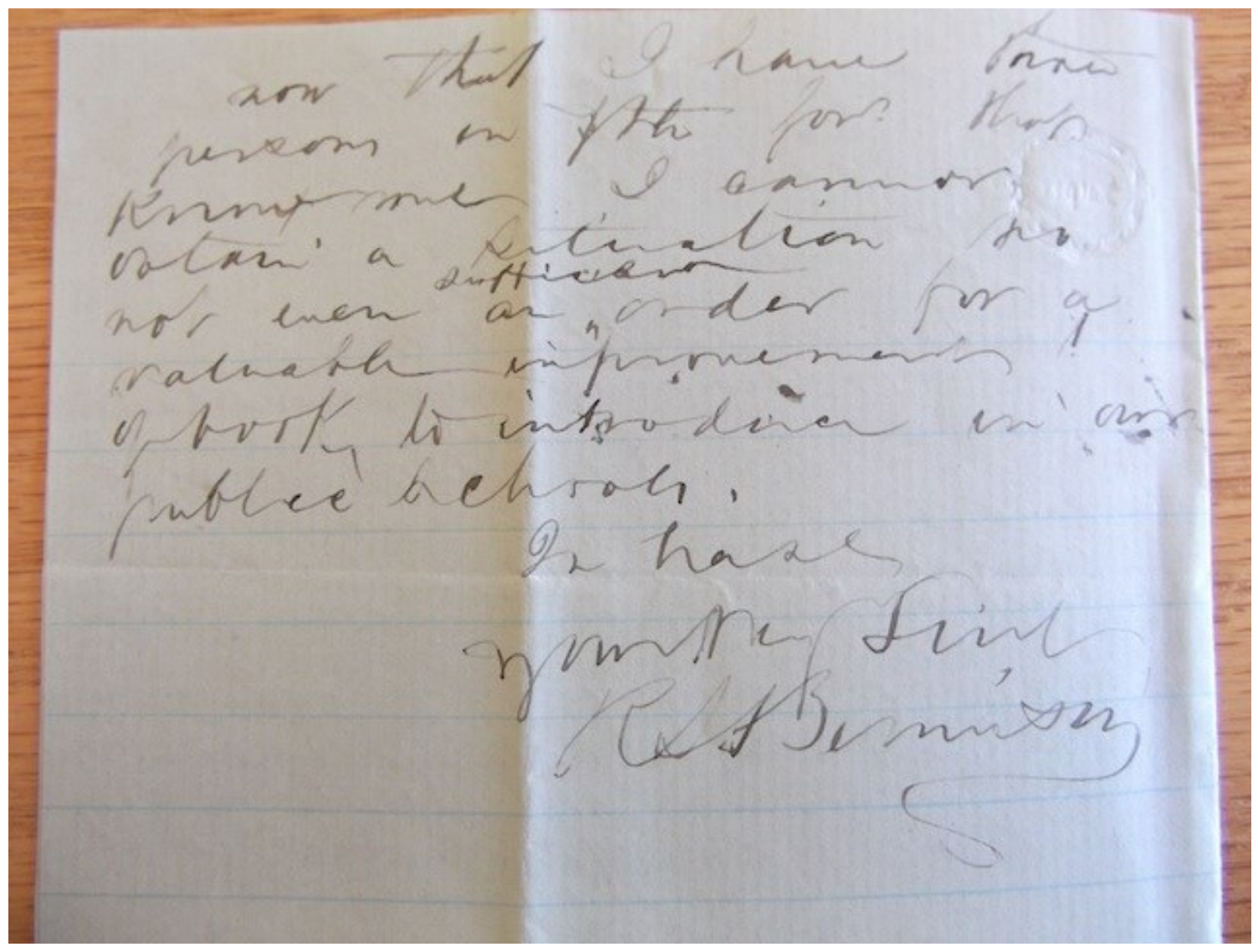

Figure7. 2. Handwriting Sample. LAC, Tilley Fonds, vol. 6, R.S. Bennison to Tilley, 12 August 1859.

Here, it seems, his anger caused him to forget the power relations involved in patronage networks, as he dismissed those who received government appointments as fools. The singling out of "temperance men" as people who ignored him was a pointed reference to Tilley, who was a leading supporter of temperance in this period. His disgust reflected his frustrations, but also condemns the quality of the appointees. And the lack of attention to his penmanship reflected, too, a man approaching a near-frenzy over his and his family's conditions. ${ }^{673}$

\footnotetext{
${ }^{673}$ The lack of attention to penmanship is especially telling given Bennison's interest in it as an art and his proposal for national instruction in the subject. In another letter to Tilley he declared "I have made an important discovery in the art of Penmanship." He was frustrated that teaching this art was not valued in New Brunswick, since "when I consider that the art of penmanship is considered of so much importance
} 
Other appeals based on anxieties of family concerns took more moderate tones. Paschal Leclerc wrote to George-Étienne Cartier, Quebec's leading Conservative politician, in 1870 and connected emotions, family responsibilities, and political activity. Asking for a place in the Montreal Post Office, he reminded Cartier of his political work, hoping Cartier "n'avez pas oublié ce que j'ai fais en temps pour la partie, et pour ce dont je vous refire [sic] à nos amis à Montréal." If Cartier were to grant the request he would "obligerez un père de famille qu'a perdu sa femme et dont la position n'est heureux." Leclerc highlighted the intimate complexities of patronage relations. Happiness, family situations, work, and reciprocity were entangled. Patronage appointments were used to allocate public positions and to consolidate patrons' authority. The effects of these appointments, however, were sometimes felt in intimate and personalized ways.

An 1874 letter to Nova Scotia's provincial secretary similarly used an emotional description of family concerns. Despite being written in a period when civil service reform was garnering support, the applicant buttressed his request for an appointment with reference to his personal anxieties: "If I am disappointed in getting the Inspector's situation I really must suffer this winter as I am not teaching and have lost what little money I had in trying to sell Howe's Book." ${ }^{675}$ The letter pointed to training as a teacher, and his allegiance with Joseph Howe, Nova Scotia's most prominent mid-nineteenth century politician, and a Minister in the Conservative cabinet, who passed away in 1873. It did not, however, give any indication as to his qualifications for the post. Although he

throughout the world, that for instruction in this art, in England especially, ten guineas is given as many lesson in this art." LAC, Tilley Fonds, vol. 6, R.S. Bennison to Tilley, 12 July 1858.

${ }^{674}$ LAC, Sir George Etienne Cartier Fonds, MG27 ID4, Paschal Leclerc to Cartier, 17 June 1870, 969-970.

${ }^{675}$ Provincial Archives of Nova Scotia (hereafter PANS), Provincial Secretary's Papers, RG 7, Volume 74, Folder 1, James A Smith to Hon W Annand, 19 October 1874. 
described his application as "reasonable and just," his request is framed in terms of anxiety over supporting himself through the winter.

Men sometimes used these letters as an opportunity to describe their personal concerns and anxieties. To conform to the dominant image of masculinity men asking for help rarely asked for sympathy. ${ }^{676}$ While making emotional appeals, men typically referred to ideals of respectability, and their desire for independence. This was not always the case, however. Arthur Mondou, whose letter was explored in the previous chapter, hoped that Cartier would "pitié d'un orphelin qui à perdu son bras gauche sur le Chemin de Fer du Grand-Tronc." ${ }^{977}$ More than making a sacrifice for a politically important railway, this injury seemed to be emasculating. By asking for pity he forfeited his independence; by comparing himself to an orphan he infantilized himself.

Women writing to politicians made similar emotional appeals, although they were usually on behalf of a husband or son, as women could not be civil servants until 1882 . As Cindy Sondik Aron notes for the American civil service in the 1850 s, women were given more leeway to show distress and concern in their letters. ${ }^{678}$ Nicole Eustace's recent work complicates this, arguing that women's expressions of emotion were more nuanced than they have been portrayed, mediating between expressions of anger and frustration with attempts to circumvent popular conceptions of women as passionate and consequently irrational. ${ }^{679}$ The women writing to Canadian politicians were not necessarily more emotional than men writing in the same period. The constructions of

\footnotetext{
${ }^{676}$ In Bowing to Necessities: A History of Manners in America, 1620-1860 (Oxford: Oxford University Press 1999), C. Dallett Hemphill refers to manners and other social rituals as "quietly creating, communicating, and controlling status" (9). Gender is one of the social rituals that governs expectations and how behaviour is read.

${ }^{677}$ LAC, Cartier Fonds, vol. 5, Arthur H. Mondou to Cartier, 20 July 1872, 2238.

${ }^{678}$ Cindy Sondik Aron, Ladies and Gentlemen of the Civil Service: Middle-Class Workers in Victorian America (Oxford: Oxford University Press, 1987), 102.

${ }^{679}$ Eustace, Passion is the Gale, 244.
} 
gender, however, did mean that women could sometimes ask for help in more direct ways than men. ${ }^{600}$

An 1869 letter to Cartier from Mme Labelle sought a position for her husband. She asked Cartier, "si de quelque manière nous pourrons espérer quelque chose. On me dit que 'vous pouviez tant, que les obstacles s'aplaniront devant son mot de votre part, est-ce que vous n'auriez pas un petit mot de sympathie pour nous ?"681 Resulting from the constructions of masculinity and femininity, independence was less a performative concern for women. Another woman writing to Cartier, Mme Fournier, made a plea for his help: “j'espère qu vous voudrez vous rendre à mes désirs." She then connected her family's dire circumstances to Cartier's good will: “vous êtes notre dernier ressource, si vous ne nous venez en aide, par quelques places que vous pourrez facilement lui faire avoir, il nous joindra de mettre dans quelques petits coins et là réunion nos enfants près de nous et de résigner à mourir, si personne daigne nous venir en aide. ${ }^{.682}$ Rather than list her husband's qualifications, she painted a picture of a family with few options struggling to survive. Rusty Bittermann explores a similar maneuvering between gender

\footnotetext{
${ }^{680}$ Cecilia Morgan raises the issue briefly in her 1994 study of Laura Secord in late-nineteenth-century nationalist and imperialism narratives. Morgan notes that, after her husband's death in 1841, Secord wrote two letters to Governor Sydenham. One letter asked that her son be made customs' collector, a position previously held by his father. The other letter asked for a pension. Cecilia Morgan, "'Of Slender Frame and Delicate Appearance': The Place of Laura Secord in the Narratives of Canadian Loyalist History," Journal of Canadian Studies, 5:1 (1994), 201. Carol Wilton further outlines examples of female petitioning on behalf of male relatives following the Rebellion of 1837. Even as these women engaged public, political issues this process affirmed rather than disrupted the masculinization of formal political space. For although often circulated by women, these petitions only collected signatures from men. Carol Wilton, Popular Politics and Political Culture in Upper Canada, 1800-1850 (Montreal and Kingston: McGillQueen's University Press, 2000), 6. For Britain, Mary Poovey notes that at times paternalism could be made to work to women's advantage: "in some very practical ways women had always been protected in the values and allegiances of paternalism." As paternalism was replaced with competition women were still tied to paternalistic values, but increasingly limited to the private sphere. Mary Poovey, The Proper Lady and the Woman Writer: Ideology as Style in the Works of Mary Wollstonecraft, Mary Shelley, and Jane Austen (Chicago: The University of Chicago Press, 1984), xv.

${ }^{681}$ LAC, Cartier Fonds, vol. 1, Mme Labelle to Cartier, 24 May 1869, 408.

${ }^{682}$ LAC, Cartier Fonds, vol. 2, Mme J.A. Fournier to Cartier, 21 March 1870, 580.
} 
constructions during the Escheat Movement in Prince Edward Island of the 1830s.

Bittermann shows how women appealed to gender stereotypes to avoid punishment for sometimes violent resistance to rent collectors and colonial authority. ${ }^{683}$ Modes of resistance in Bittermann's example, and modes of survival in the above were based in social conditions and expectations. This meant that even when seeking the same goals as men, women sometimes used different techniques. Directly asking for sympathy from a politician was a sharp contrast to the ways in which most men framed their requests.

Mme Labelle's letter further connected her request to concerns over French Canadian emigration. She wrote, "croyez que mon cœur soigner de laisser le Canada pour aller vivre dans cette terre des États ou je serais étrangère a tout, loin de ma patrie, loin des amies. Nous avons des offres assez avantageuses, mais je préférais vivre médiocrement et rester ici." She concluded that should her husband get a position "nous resterons et nous serons heureux." ${ }^{, 64}$ While framed in terms of remorse and happiness, this letter also used nationalist sentiment. French Canadian emigration to the United States was connected with concerns over the decline of traditions and of the French language. ${ }^{685}$ Mme Labelle connected her family's well-being and happiness with that of French Canadian culture and to the health of the French-Canadian social body in Quebec. Her letter combined personal and political, intimate and social circumstances.

\footnotetext{
${ }^{683}$ Rusty Bittermann, "Women and the Escheat Movement: The Politics of Everyday Life on Prince Edward Island" in Janet Guildford and Suzanne Morton, eds., Separate Spheres: Women's Worlds in the $19^{\text {th }}$-Century Maritimes (Fredericton: Acadiensis Press, 1994), 23-37.

${ }^{684}$ LAC, Cartier Fonds, vol.1, Mme Labelle to Cartier, 408.

${ }^{685}$ There is a large body of work on property, out-migration and French Canadian nationalism in the midand late-nineteenth century. See, for example, Gabriel Dussault, Le Curé Labelle: messainisme, utopie et colonization au Québec, 1850-1900 (Hurtubisie : Montréal 1983); J.I. Little, Nationalism, Capitalism, and Colonization in Nineteenth Century Quebec: The Upper St. Francis District (Montreal and Kingston: McGill-Queens University Press, 1990); and, Serge Courville, Rêve d'empire: le Québec et le rêve coloniale (Ottawa : Les Presses de l'Université d'Ottawa, 2000).
} 


\section{Partisan Feelings}

While some applicants used patronage requests to reveal details of their private lives, others used emotional connections to show their political connections and party allegiances. An 1863 letter to Samuel Tilley from Samuel Robinson asked for help finding his unemployed son-in-law, P.B. Vincent, a position as tidewaiter. He described Vincent as having "been in business in St. John but has not been successful." Although not elaborated on, the reference to "business," as explored in earlier chapters, tended to be shorthand for efficiency, economy, and merit-based promotion. This appeal was undercut, however, by Vincent's lack of success, which made him dependent on his father-in-law's connections. Seemingly acknowledging the unmistakable reality of the situation, Robinson instead appealed to Tilley's heart: "if you could secure him the situation you would not only confer a kindness on one of your old friends and his family but also on me.,

Relying on the emotive power of friendship was frequently used to circumvent the official route to a position. In 1863, Richard Robertson wrote to Tilley asking for appointment as Sheriff. As we saw in Chapter Five, he explained that, he could procure a petition "numerously and respectably signed." He would prefer not to, however, since "it seems to me degrading to have my name hawked around the country for the sake of a situation in the power of a friend to bestow. ${ }^{, 687}$ While suggesting that he could find the necessary community support, he made an appeal to Tilley's friendship. Presumably there was an expectation of reciprocity for his past support. This letter also speaks to the shifting relationship between respectability and independence in the period. Until the

\footnotetext{
${ }^{686}$ LAC, Tilley Fonds, vol. 14, Samuel Robinson to Tilley, 29 May 1863.

${ }^{687}$ LAC, Tilley Fonds, vol. 14, Richard Robertson to Tilley, 16 March 1863.
} 
reforms of the 1880s, presenting letters of support and a signed petition to the Government was the usual means to secure a position. To Robertson, however, seeking the support and assistance of respectable members of the community was more degrading than asking for help from his friend. Both options involved a forfeiting of his independence, but to different degrees.

This play between respectability and independence can again be seen in an 1870 letter to Cartier, from J. Hickson. Hickson opened by apologizing for trespassing upon Cartier's "time, on behalf of others, which I would certainly never think of doing on my own individual account." Here Hickson established his own independence. In addition to being a matter of pride and tact, this may also have strengthened his recommendation. The fact that he stated he would never write for his own account also implied that there was a stigma attached to asking for help. His pride and independence separated him from those who needed his and Cartier's help. In his appeal Hickson explained that "My present communication should be addressed to the Hon. Mr. Langevin, but as I do not know him as intimately as I know you, I want to enlist your kind offices in furthering the object I have in view." ${ }^{688}$ Here Hickson demonstrated a willingness to maneuver between official and personal networks. Langevin, as Minister of Public Works, oversaw much of the public appointment process. Hickson recognized this, but first turned to Cartier, whom he knew more "intimately."

Another letter to Cartier, from L.M. Lefaivre, noted an open position in the "bureau du revenue." Lefaivre worked in a penitentiary, but felt it was time to move to something else. Pointing to the embodied elements of work, he declared "je voudrais pas mourir en prison.” The solution to his concerns was his friendship to Cartier. He asked

\footnotetext{
${ }^{688}$ LAC, Cartier Fonds, vol. 2, J. Hickson to Cartier, 25 April 1870, 717-718.
} 
"Aurait-tu la bonté de penser a un ancien ami de collège et du jeune age pour me faire avoir cette situation?" ${ }^{689}$ Applicants attempted to take advantage of whatever avenues to appointment they could. Sometimes that meant referencing their qualifications or reciprocity. Other times, it involved making a sentimental appeal to friendship and longstanding connections.

This reliance on personal favours and connections was sometimes expressed with more urgency than in the previous examples. Supporting a prominent politician sometimes involved risks and sacrifices. In exchange for this support, once a politician was in power it was expected that he would repay his allies. For example, writing to Charles Tupper, the Conservative Minister of Public Works, in 1878, W. Miller expressed his frustrations with Tupper's failure to reward his support preceding Confederation. Miller stated, "since hour I supported confederation, I have never had a lucky day, and scarcely a happy one, however much I have tried to cancel my misfortunes." He also complained that "I see individual after individual without a tenth of my claims, and with none of my sacrifices, passed over my head by men whom I had a right to expect better things." Miller was vague about what positions he wanted, or how he was qualified for them. The basis of his claim was his long party service, and his support of Confederation, and his suffering for his fidelity. The lack of specificity may itself have reflected the intimacy between Miller and Tupper - perhaps, he did not need to state what positions he wanted because Tupper was (or should have been) already aware of them. By failing to reward his support, Tupper was not meeting expectations of reciprocity that underscored Canadian politics. Miller concluded with a note of

\footnotetext{
${ }^{689}$ LAC, Cartier Fonds, L.M. Lefaivre to Cartier, 12 April 1872, 1847-1848. This was one of the few letters where the outcome is known. Cartier's office responded to Lefaivre, explaining that Cartier looked into the situation "et qu'il s'est assure à son grand regret, que la place dont vous parlez était déjà donnée" (1850).
} 
disappointment: "I really expected different things from you, and you had given me reason to expect different than that." ${ }^{\prime 690}$ The pain here is not simply one of lost professional opportunity; it also reads as one of personal betrayal. This letter was written in 1878 , when debates on civil service reforms were gaining currency and even as members of parliament from both parties openly supported professionalization, Miller still framed his appeal to Tupper with expressions of emotion.

Miller expressed his frustrations and disappointments again in an 1881 letter. While criticizing an appointment Tupper made without his recommendation, Miller outlined his role as a local broker. In his work, he claimed to "have been guided by two objects - the efficiency of the public service and the just rewards of party claims." This restated the two understandings of patronage navigated in debates on civil service reforms. As a local advisor Miller was in an interesting position to comment on this. $\mathrm{He}$ was less reliant on patronage than those seeking appointments. At the same time, as someone in the community, he was in more contact with job-seekers than the top patrons. Miller's position also indicated the classed elements of patronage networks. While still subordinate to Tupper, he was less dependent on him than a typical job-seeker. Resulting from the semi-privileged position, he was able to comment in ways that other letters writers were not. He described this work as being "as thankless as it is very often unpleasant," adding "thankless treatment is no new thing to me since I have been in public life. ${ }^{691}$ Here he combined the language of public service with one of personal

\footnotetext{
${ }^{690}$ LAC, Sir Charles Tupper Fonds, MG26 F, Reel C3203, W. Miller to Tupper, 30 Nov 1878, 2190-2191.

${ }^{691}$ LAC, Tupper Fonds, vol. 5, W Miller to Tupper, 21 November 1881, 2464. Alan Gordon notes a similar frustration in the career of Edmund Bristol, the MP for Centre Toronto in the early twentieth century.

Bristol hoped to be made a senator. This appointment never came and as a result Bristol "took less and less interest [managing patronage] in his constituency." Alan Gordon, "Patronage, Etiquette, and the Science of Connection: Edmund Bristol and Political Management, 1911-1921," Canadian Historical Review, 80:1 (1999), 31.
} 
frustration. Rather than framing this as sacrifice, he expressed his service as one of personal insult. This was emphasized in his conclusion, when he stated "I have determined that for the future I shall not allow myself to be troubled or trammeled with these annoying affairs. I shall have nothing to do with the patronage of this county." ${ }^{692}$ He was stepping away from administering patronage because he felt he was not receiving the reciprocal benefits owed to him.

The reciprocal relationship between patrons and clients sometimes operated in reverse, with loyalty being promised in exchange for a position. An 1887 letter to Tupper sent on behalf of a successful applicant expressed that he was "pleased and intensely grateful." The appointee's brother wrote that "to see him so delighted with his appointment, makes us feel more deeply obliged to you. You have always had the very sincere admiration of this family. Now, more than ever, our heartfelt wishes for your success and prosperity in the important undertakings to which you devote your time." ${ }^{, 693}$ Here we see the patron-client relationship from the client's point of view. Their loyalty was Tupper's reward for making an appointment they sought, rather than the other way around. This letter also suggested that networks of support and reward were multifaceted, since not only would the applicant be indebted to Tupper, but so would his friends and family. Personal connections continued to be an important part of Canadian politics, even as reforming movements gained support, and such connections could manifest themselves in strong emotional declarations.

The connections of loyalty, service and reward were not always linear between patron and client. William Henry Thorne, a New Brunswick businessman and future Tory

\footnotetext{
${ }^{692}$ LAC, Tupper Fonds, vol. 5, W Miller to Tupper, 21 November 1881, 2464-2465.

${ }^{693}$ LAC, Tupper Fonds, vol. 6, C3204, Marshall Saunders to Tupper, 12 July 1887, 3493-3494.
} 
senator, made a sentimental appeal to the Tory leader, John A. Macdonald, for James Domville, without Domville's "solicitation, or...his knowledge." Domville had been a Conservative MP for New Brunswick, as such "in former years our relations were very intimate and friendly." After losing his seat in the 1882, Domville became critical of the National Policy and left the Conservative Party. Since then, according to Thorne "we have been of lesser on speaking terms. ${ }^{, 694}$ This was also true of Domville's relationship with Macdonald, to whom he had written several times but without receiving a response. In a letter to Lady Macdonald, Domville's wife, Anne, suggested that "perhaps the letters have gone astray or perhaps they have been mislaid." ${ }^{\circ 95}$ The decline of their relationship was related to party politics. At the same time, Thorne was able to ask Macdonald to find Domville something because of his past work, "his party service between ' 72 and '78." In addition to rewarding him for this service, Thorne "had received rather a heart-troubling letter from his wife. ${ }^{696}$ More than just friendship or reciprocity, Thorne claimed to be responding to an emotional appeal from Domville's wife. By acting as a broker between Macdonald and Domville, Thorne underscored the ongoing interaction between partisanship, reciprocity, public work, and private issues.

In the above example, Thorne stressed that he was writing without Domville's knowledge. This underscored that the reliance on personal connections and favors in patronage networks was at times quite complex. John Cameron, a Bishop in Nova Scotia frequently wrote to Charles Tupper regarding patronage and other political issues. In one

\footnotetext{
${ }^{694}$ LAC, Sir John A. Macdonald Fonds, MG26 A, vol. 331, William Henry Thorne to Macdonald, 21 January $1889,147910$.

${ }^{695}$ LAC, Macdonald Fonds, vol.331, Mrs. A.I. Domville to Lady Macdonald, 9 February 1889, 149713, She also asked Lady Domville to influence her husband "She appealed to Lady Macdonald "for the sake of old times."

${ }^{696}$ LAC, Macdonald Fonds, vol. 331, William Henry Thorne to Macdonald, 21 January 1889, 1149711.
} 
letter from 1888, he was promoting Donald Chisholm, a Member of Parliament from British Columbia, for appointment as a Senator. He noted, "Mr. Chisholm is not aware that I am interesting myself on his behalf, but if you succeed in obtaining for him the desired appointment you would doubly oblige me by letting know that I have written." ${ }^{697}$ In addition to wanting a position for his friend/ally, Cameron wanted Chisholm to be informed of his intervention. He asked Tupper for two favors (to get Chisholm a position and let him know). The second favor put Chisholm in a position of obligation to Cameron. Chisholm's obligation to Cameron had its own networking effects. According to Cameron, Chisholm had "a host of relatives in my diocese... who would be delighted at his promotion, and rendered much better disposed towards the Govt to which they should owe such a bon for their friend." ${ }^{, 698}$

Another letter from Cameron underscored that patronage relations involved the feelings of more than just patrons and clients. Recommending an applicant for Collector of Customs, Cameron asked Tupper if the appointment could be given "without offending the friends of their party in this Country." ${ }^{\circ 99}$ This was about balancing personal and local interests, which were important components in the appointment process. It was also, perhaps, about managing egos of local party members. As the example of W. Miller described above stressed, managing party relations was sometimes a personally exhausting and thankless task. Anxieties and emotions sometimes figured in how people recommended and responded to appointments. The appointment process involved more than consolidating political power. It was also about administering to the egos, reputations, and emotions of those making recommendations.

\footnotetext{
${ }^{697}$ LAC, Tupper Fonds, vol. 6, roll 3204, John Cameron to Tupper, 24 March 1888, 3819-3820. 698 Ibid.

${ }^{699}$ LAC, Tupper Fonds, C3202, John Cameron to Tupper, 13 Jan 1879, 2240-2241.
} 


\section{Writing Power Relations}

Participating in patron-client relationships was participating in unequal power relationships. ${ }^{700}$ In writing to politicians, job-seekers were explicitly addressing these relationships, and reiterating the legitimacy and their acceptance of this hierarchy. ${ }^{701}$ Even if the patron and client were close, there were certain conventions expected. In a study of American manners, C. Dallett Hemphill refers to manners as governing "rulebound and symbolic behaviors that we perform in the presence of others."702 Conduct manuals stressed that people, especially middle-class men, should present themselves as polite and cheerful, participating in market relations, and following established etiquette. These conventions governed how people spoke, dressed, and wrote letters. ${ }^{703}$ An 1856 letter to Cartier, then co-Premier of the United Province of Canada with John A. Macdonald, opened by noting that, “[j]e suis faché d'avoir à vous déranger au milieu de vos nombreuses occupations pour une affaire vraiment personnelle. Mais la situation toute particulière où je me trouve ayant à soutenir deux vieux parents me forcent de demander aujourd'hui à votre gouvernement ce que je n'ai jamais demandé à aucun ministre." The letter went on to ask for a position in "un département public" or even “pour le moment d'une emploi temporaire."704 His opening apology underscored the separation between personal and public matters, the latter of which should be the focus of

\footnotetext{
${ }^{700}$ Carl H. Landé, "Introduction: The Dyadic Basic of Clientelism," in Steffen W. Schmidt, Laura Guasti, Carl H. Landé and James C. Scott, eds., Friends, Followers and Factions: A Reader in Political Patronage (Berkeley: University of California Press, 1977), xxi; Vincent Lemieux, Le Patronage politique: une étude comparative (Québec : Les presses de l'Université de Laval, 1977), 217. D.B. Skelly stated this unequal relationship when he apologized for addressing Macdonald "too normally." LAC, Macdonald Fonds, vol. 302, D.B. Skelly to Macdonald, 24 October 1872, 137924.

${ }^{701}$ See also: LAC, Tilley Fonds, vol. 2, John Haws to Tilley, 16 July 1867; LAC, Tilley Fonds, vol. 1, Ebenezer Scribner to Tilley, 18 November 1857; LAC, Cartier Fonds, vol. 2, Thomas McGinn to Cartier, 20 April 1869, 259-269.

${ }^{702}$ Hemphill, Bowing to Necessities, 3.

${ }^{703}$ Ibid., 144-147, 217.

${ }^{704}$ LAC, Cartier Fond, vol. 2, Cyrille Boucher to Cartier, 18 July 1856, 17o-17p.
} 
an elected politician. Even though, as politicians frequently noted, much political work was assigning patronage appointments, by the late 1850s this type of request was seen as a forfeiting of independence. The applicant stressed that he would not ask any other minister for such a favor. In addition to showing his knowledge of patronage networks, this suggests the intimacy of the request. It was a personal and familiar matter, and a matter about which he was reticent to trouble Cartier. The use of the verb "force" is also telling, as it implied that the applicant was no longer in control of the situation and had exhausted all other routes. He was thus desperate in his personal needs, but also polite in his presentation of self.

These same tropes were used in an 1869 letter to Cartier. The writer recognized that it was "a time when measures of a very comprehensive and important character, so fully claim your time and consideration." Since public issues were pressing, "I feel that to obtrude minor matters, of a rather personal character upon your notice may not unfairly be regarded as inopportune, if not improper." Nevertheless, the writer hoped that "if urgent necessity may not be accepted to excuse the act, I feel that I have none other than to urge that could have equal weight or be equally true." ${ }^{705}$ This again highlights the separation between public and personal concerns. The writer suggested that public matters were more significant than his private concerns, while still asking for an intervention from Cartier. An 1870 letter from J.S. Theberge, a priest, on behalf of this brother-in-law stated this even more strongly: "Je commence par vous demander pardon si j'ose attirer votre attention sur un sujet qui est loin de regarder le bien public. ${ }^{, 706}$ Even though the vast bulk of Cartier's records at Library and Archives Canada are letters

\footnotetext{
${ }^{705}$ LAC Cartier Fonds, Thomas McGinn to Cartier, 20 April 1869, 259-260.

${ }^{706}$ LAC, Cartier Fonds, vol. 2, J.S. Theberge to Cartier, 2 April 1870, 622-625.
} 
requesting patronage, many of these letters apologize for intruding on his time with personal matters. Although the personal and the political were constructed as separate, they interacted in matters of administration and appointment.

But perhaps we ought to expect nothing less. As Patrick Joyce notes, nineteenthcentury liberalism "depended on cultivating a certain sort of self, one that was reflexive and self-watching. Yet this self, as it were, also watched liberalism., ${ }^{, 707}$ Stating their reticence in asking for help while still asking for help can be understood as such an act of watching and self-watching. In aiming to govern themselves and their households properly - i.e. independently - their letters demonstrated to the politicians that fit the characteristics of a deserving applicant. Theberge's letter reflected the ironic tension between performing liberalism while asking for help. He wrote, "C'est la seule faveur que j'ai jamais demandé. Je sais que les solliciteurs de faveur et les chercheurs de places ne sont pas agréables, mais que voulez-vous - il faut bien quelque fois s'aider." ${ }^{\text {708 }}$ Again he reiterated his own independence, and distaste for job-seeking, while pointing towards the circumstances that forced him to do so.

\section{Politics as Violence, Appointments as Strategy}

Rhetorics of violence were another feature of letters requesting appointments that complemented the more intimate approach we have been examining so far. In such letters partisan politics were cast in terms of spite and revenge. Martin Pâquet has written about sport metaphors and politics in nineteenth-century Quebec, arguing that these metaphors implied a shared set of rules and assumptions. Pâquet notes that especially during times of bipartisanship political rivals, like the Whigs and Tories or the Bleus and Rouges, are

\footnotetext{
${ }^{707}$ Patrick Joyce, The Rule of Freedom: Liberalism and the Modern City (London: Verso, 2003), 4.

${ }^{708}$ LAC, Cartier Fonds, vol. 2, J.S. Theberge to Cartier, 2 April 1870, 622-625.
} 
ordered like teams, where leaders face-off in a political arena. ${ }^{709}$ In his memoir detailing his dismissal from the public service, William Kingsford reflected this view. He stated, "the dispute ceases to be a tournament between two persons, each having his supporters, with the possibility of advancing pleasing and plausible arguments." ${ }^{, 710}$ The shift away from a tournament with understood codes of debate and conduct created a space where personal passions and interests were stressed. In contrast to rationalist language "pleasing and plausible arguments" - these arguments were cast in terms of personal distaste and revenge. In her study of the Colbys of Carrollcroft, Marguerite Van Die cites a revealing example of this. John A. Macdonald wrote to the Charles Caroll Colby during the 1891 election, warning that the "the Grits are fighting us all over the Dominion," and thus needing Colby to arrange for "funds to carry on the war."711 The use of violent and military images suggests a less cooperative and unified vision of democratic politics, one that reinforced some of the antagonistic qualities of Canadian liberal governmentality. ${ }^{712}$

\footnotetext{
${ }^{709}$ Martin Pâquet, "Le Sport de la politique" : transferts et adaptions de la culture politique britannique au Québec, 1791-1960' in Jean Morency, Helene Destrempes, Denise Merkle, et Martin Pâquet. Des cultures en contact: Visions de l'Amerique du Nord francophone. (Quebec: Nota Bene, 2005), 161. Pâquet also suggests that through ideas of spectators and participants, these metaphors entrenched elite bourgeois power.

${ }_{710}$ William Kingsford, Mr. Kingsford and Sir H. Langevin, The Case Considered with the Official Correspondence: A Memoir for the Historian of the Future (Toronto: R.G. McLean, 1882), 4.

${ }^{711}$ Stanstead Historical Society, Colby Fonds, Charles Carroll Colby Papers, Series 2:B, Box 2:3, Macdonald to CC 25 March 1891, quoted in Marguerite Van Die, Religion, Family and Community in Victorian Canada: The Colbys of Carrollcroft (Montreal and Kingston: McGill-Queen's University Press, 2005), 178.

${ }^{712}$ This antagonistic form of government was more pronounced and sustained for those outside the period's privileged construction of white, propertied males. Robin Jarvis Brownlee, notes that this liberal form of rule was "directly linked with the beginnings of an extended political and cultural conflict between the state and First Nations." Robin Jarvis Brownlee, "A Persistent Antagonism: First Nations and the Liberal Order," in Jean-François Constant and Michel Ducharme, eds., Liberalism and Hegemony: Debating the Canadian Liberal Revolution (Toronto: University of Toronto Press, 2009), 299. Dan Horner has explored the sometimes violent outcomes of this order. Dan Horner, “'Shame on You as Men!': Contesting Authority in the Aftermath of Montreal's Gavazzi Riot, 1853," Histoire sociale/ Social History, 44:87 (2011), 29-52; "Solemn Processions and Terrifying Violence: Spectacle, Authority and Citizenship during the Lachine Canal Strike of 1843," Urban History Review / Revue d'histoire urbaine, 38:2 (2010), 36-47; Taking to the Streets: Crowds, Politics and Identity in Mid-Nineteenth Century Montreal, PhD Dissertation (Toronto: York University, 2010).
} 
Antagonism was certainly prominent in an 1858 letter to Samuel Tilley, written to "make it known in the proper quarter with a view to displace a spoiled young man from an office [Crown Land surveyor] which he never could have been competent for."

Although he noted that the Surveyor was not qualified, he did not elaborate on what those qualifications were. The author instead explained that "he [the Surveyor] will certainly be a disgrace to the parties who were the means of having him appointed, and how such a looking character as he is could really get such an office I know not, he has not in the first place a particle of common sense, and therefore like all other such characters makes a clown of himself."713 This framed the necessary characteristics for the position with vague references to party loyalty, respectability and common sense. He went on to make a more personal and specific accusation, however. The letter went on to state his concern that "he would use his influence among his extensive acquaintances to injure me." This letter asking for dismissal can be understood then, as a reaction to a threat and as a form of revenge. Personal networks were not only used to help people. At times people would make use their of connections to disadvantage their rivals.

Charles J. Burpee, who went on to be a Liberal MP and eventually a Senator, wrote to Tilley after the pro-Confederation forces had been defeated in a general election. Following this election he was removed as Postmaster for Sheffield, New Brunswick. Burpee alleged that his opponents "make many excuses and assign many reasons for my removal, tho striking portions of this community fail to see in the act anything less spite and petty revenge." ${ }^{, 715} \mathrm{He}$ asked to be reinstated once the Confederation party was back in power. Partisan federal politics were enacted at a personal level. This is an example of

\footnotetext{
${ }^{713}$ LAC, Tilley Fonds, vol. 3, Letter to Tilley, May 211858.

${ }^{714}$ Ibid. Emphasis in original.

${ }^{715}$ LAC, Tilley Fonds, vol. 18, Charles J. Burpee to Tilley, 23 September 1865.
} 
the victor-spoils view of administration that was, at times, decried by reformers in the 1870s. ${ }^{716}$ Appointments were frequently referred to in oppositional and partisan terms. Even the motto 'to the victors go the spoils' drew upon militaristic imagery and relies on an antagonistic understanding of politics.

An 1870 request to Cartier also used partisan opposition as the basis for a claim.

M. Brouard, writing on behalf of his brother-in-law, asked for help with an appointment as a gardener in the St. Jean Dorchester Park. He explained that "le surintendant qui est un Rouge de la vielle école à été placé par M. Dorion et dit qu'il ne peut tous faire.” Brouard went on the establish his own independence and party loyalty, claiming that “c'est la premier [sic] fois que nous demande un faveur, ayant toujours travaillé pour vous comme vous savez." ${ }^{, 717}$ While the language in Brouard's letter was subtler than in the examples above, it still suggested that partisanship was crucial in obtaining a public position. He did not explain his brother-in-law's qualifications for the position, but instead highlighted that a political opponent was likely keeping him out. This also suggests how deeply partisanship was entrenched; even park gardeners were thought to need the appropriate political connections.

This aggressive partisan rhetoric continued even as the movement for professionalization gained momentum. An 1878 letter to Nova Scotia's provincial secretary lamented the fact that "Our friends/allies' enemy has gained his seat in Antigonish, I will not say how, but I feel ashamed to say that the Catholic constituency in the diocese of Arichat has returned three Grits to the Dominion Parliament." $" 718$ While it

\footnotetext{
${ }^{716}$ See Chapters 2 and 3.

${ }^{717}$ LAC, Cartier Fonds, vol. 2 M. Brouard to Cartier, 11 March 1870, 555-556.

${ }^{718}$ PANS, RG 7, vol.84, folder 1, John Macdonald to Provincial Secretary, 23 September 1878, 102. Arichat is the diocese where John Cameron, mentioned above, was Bishop.
} 
is unclear if it is because of his party affiliation only, or perhaps both that and his religious affiliation, it is significant that, in the context of a personal letter, the writer would speak of an 'enemy' in contrast to the more cordial rhetoric typically used in public political debates. A letter sent John A. Macdonald in the aftermath of the 1882 election also used combative imagery. While asking to be appointed to an Ontario customs office, G. Wilson noted that "[t]he Grits... are extremely docile now since they have discovered that they are so thoroughly beaten. And no doubt, for many years in the future." ${ }^{, 719}$ Rather than the idealized language of the public sphere - disregard for status, emphasis on public discussion and inclusion, and "bridg[ing] the gap between enlightened self-interest and orientation to the common good" - this was a rhetoric of struggle. ${ }^{720}$ At the same time that the civil service commission was attempting to remove partisanship, politicians still conceived of appointments as ways to engage in political combat.

Following the 1878 election new nominations for public offices were made. Macdonald noted that, "for the very reason of having him disappointed I write to you." Here we can see the appointment process being used as a tool to frustrate one's "enemy." Just as personal connections were used to make claims to an office, they were sometimes used to block another's claim. Of the nominee for school inspector, Macdonald wrote that he is "a dirty lump of a sycophant, a squatter without claim, although higher authority

\footnotetext{
${ }^{719}$ LAC, Macdonald Fonds, vol. 316, G. Wilson to Macdonald, 23 June 1882, 143088.

${ }^{720}$ Jurgen Habermas, "Further Reflections on the Public Sphere," Craig Calhoun, ed., Habermas and the Public Sphere (Cambridge, Mass: MIT Press, 1992), 448; Calhoun, "Introduction: Habermas and the Public Sphere," Habermas and the Public Sphere, 13. In his critique of how historians have used Habermas's theory of the public sphere, Harold Mah describes it as a "sphere of pure reason," which creates an authority above the State's. Harold Mah, "Phantasies of the Public Sphere: Rethinking the Habermas of Historians," The Journal of Modern History, 72:1 (2000), 156.
} 
among the people, which has no claim on you, may claim for him." ${ }^{721}$ In an ironic turn, the applicant's relationship with his patron was ridiculed for being sycophantic. This suggests the importance of perceived independence to public service - a point further emphasized by reference to the applicant being a squatter without property. This condemnation further highlights the coexistence of personal/partisan relationships with professionalizing ones. While making a personal attack Macdonald criticized his enemy for his personal relationships.

These metaphors of conflict and violence were not only used to describe opponents in political contests. An anonymous memo to John A. Macdonald discussed the Postmaster of the Morrisburgh, Ontario post office. The memo outlined how the local Conservatives' preferred candidate had not been appointed, mainly because of a petition circulated by "leader of the Grits aided by 3 or 4 disappointed conservatives." the memo was anonymous it is likely that it was worded more strongly than it would ordinarily have been. This was a fact the writers recognized, noting, "it may be said that strong language is used in this memorandum. This is admitted, but the result will show that the language used comes far short of the feeling that is intended to express, and the determination it conveys." ${ }^{, 723}$ The writers expressed their emotional response to the appointment: "the Friends of the Government are utterly discouraged and enraged.",724 Despite this discouragement, they stressed their determination with a rhetoric of violence, promising to "keep fighting" even though "we have suffered defeat at the hands of our

\footnotetext{
${ }^{721}$ PANS, RG 7, vol.84, folder 1, John Macdonald to Provincial Secretary, 23 September 1878, 102. In the same letter, Macdonald wrote of another nominee: "Copeland the druggist... is less of man than any of his breed and you know them."

${ }^{722}$ LAC, Macdonald Fonds, vol. 307, Anonymous to Macdonald, 1870, 139908.

${ }^{723}$ Ibid., 139911.

${ }^{724}$ Ibid., 139909.
} 
political opponents time after time." ${ }^{725}$ Interestingly, this reflected the sporting metaphors examined by Pâquet. Defeat was understood to be part of politics. Being disappointed by their own party was less expected: "we have never before received a direct slap in the face from the leaders of our own party at the instance of those who have fought the battle of Gritism in the County for over a generation." ${ }^{.726}$ This suggests that politics was more than a shared contest for the public good. Partisanship divided loyalties and people were intimately connected to these public issues. Not being rewarded for their service and their 'fighting,' caused "the feeling of complete humiliation and rage which has taken possession of the minds of the large majority of conservatives in the County." ${ }^{, 727}$ The realities of patronage-networks can explain this personal and emotional reaction. When expectations of reciprocity were not met people responded intensely and emotionally.

The case of D.B. Skelly also reflected how feelings of betrayal and revenge were raised when reciprocity was broken. As mentioned in previous chapters, Skelly was an engineer and Tory promoter from Hamilton. In addition to this, in the 1860s, he gathered information on the Fenians, specifically regarding their plots to assassinate Thomas D’Arcy McGee. ${ }^{728}$ In exchange for this work and his party contributions, Skelly expected a civil service appointment that would allow him to leave Hamilton, where "infest all the offices of the road are a ultra ranting pack of grits, if I get the situation they would make it "hot for me." " 729 As with others who relied on aggressive rhetoric, this was a contrast to an idealized public sphere based on reason. Regardless of the strength of his argument, he could not debate or work with 'ranting' opponents. Skelly moved to Atlantic Canada for

\footnotetext{
${ }^{725}$ Ibid.

${ }^{726}$ Ibid.

${ }^{727}$ Ibid., 139910.

${ }^{728}$ LAC, Macdonald Fonds, vol. 489, D.B. Skelly to Macdonald, 13 October 1890, 244624.

${ }^{729}$ LAC, Macdonald Fonds, vol. 348, D.B. Skelly to Macdonald, 18 March 1878, 160049.
} 
an appointment, but found neither the work nor the weather to his liking. After that, he did not receive another appointment, and found Macdonald non-responsive to his correspondence.

Skelly explained why he was being ignored in emotional terms as well. He claimed to have been informed that the "reason you have had all along for not fulfilling your promises to me, and my friend, was to pay me for showing your private letters and my going back on the party in 73." ${ }^{, 730}$ It is impossible to know Macdonald's motivation in not appointing Skelly to a position, especially since Macdonald did not respond to this letter. What this statement can show, however, is that Skelly understood partisanship, friendship, patronage, and elections as interconnected. Skelly’s logic in making Macdonald's letters and election strategies known was simple: revenge. He explained that "I never betrayed you or the party till you betrayed me." Interestingly, the betrayal seemed not to have been Macdonald's releasing letters from Skelly to a Hamilton magistrate, P.D. Kelly, which endangered Skelly's life, but rather the failure to find him a suitable patronage job. Skelly requested that his letters to Macdonald that dealt with gathering information on the Fenians be destroyed or returned to him. For reasons that are unclear (and without Macdonald's responses to Skelly, unknowable), Macdonald sent the package to P.D. Kelly, a magistrate in Hamilton. Given the similarities in their names, this could have been an innocent mistake. Nevertheless, it had serious repercussions. Once Skelly's activities against the Fenians were made public he did not know "whose head was in the most danger. McGee's or myne [sic]," and at a "moment's notice, with an nom'de plume, I left my business, family, and friends for parts unknown and for years worked hard and saw a little money, after years it became intolerable, knowing poor

\footnotetext{
${ }^{730}$ LAC, Macdonald Fonds, vol. 489, D.B. Skelly to Macdonald, 13 October 1890, 244624.
} 
McGee was murdered."731 Skelly eventually returned to Hamilton and worked for the 1872 election, after which he was offered a position in the Maritimes. It was not until "72 and my trip to the maritime provinces had left me today a poor man," that he made the letters public. ${ }^{732}$ Skelly’s actions were connected to partisanship, loyalty and betrayal, and threats of politically motivated violence. While the 1870 s and 1880 s, were periods of political reform, politics still involved a range of seemingly irrational factors. Skelly's relationship to Macdonald was personal and political, public and private. He wanted to know if the Prime Minister was "determined to keep spite after promising to 'bury the hatchet," while at the same time "opin[ing] many of my former friends have jumped at the conclusion that I am no further use to the party as I am poor."733

This conflating of emotional rhetoric with professional concerns continued at least until the end of the nineteenth century. An 1897 letter to Tupper, from H.N. Paint, dealing with patronage and elections in Nova Scotia again used aggressive language to describe partisan and personal relationships. Paint described the upcoming election:

At present there are about 3300 electors in Richmond Co, Maybe [sic]1300 French votes, but at least half of them hate him, Against 500 Irish votes, bosom friends of Flynn, with aid to crush Morrison for deserting Flynn, his old Grit associate for many years... These are not my friends, largely as Flynn has the custom house, I shall never again support either Benoit or Morrison in a Federal contest, My two old arch enemies. I did my best in the local election for them, and was honest and energetic in my support. ${ }^{734}$

The specific details of the election are less significant here than how Paint framed it. Again religious and linguistic tensions were noted. The Catholic voters were dismissed as 'bosom friends to Flynn.' The gendered imagery here is more than just corporeal. The image also was an allusion to emotional, and consequently irrational behavior. That

\footnotetext{
${ }^{731}$ Ibid., 244624.

732 Ibid., 244622.

${ }^{733}$ Ibid., 244626; 244628.

${ }^{734}$ LAC, Tupper Fonds, C3209, H.N. Paint to Tupper, 5 May 1897. Emphasis in original.
} 
Catholic voters were also described as wanting revenge - 'to crush Morrison for deserting Flynn' - which suggests that partisanship and personal grudges were not eliminated with the expansion of professional statecraft throughout the late-nineteenth century. In referring to Benoit and Morrison as 'old arch enemies,' Paint suggests that he too harbored personal grudges. He was willing briefly to put these personal biases aside for the party interests, but not without making his own claim on party favours: "[t]here might be a spree of consideration due for this." ${ }^{, 735}$

Canadian politics underwent significant transformations and formalizations from the 1850 s to the late 1890 s. This was a period of professionalization, with several civil service acts and commissions. Historiography tends to focus on this movement for reform. Events and issues that do not fit this narrative are treated as failures or anomalies. Bill Doherty writes that as late as 1893 "the plague of patronage was still burdening the civil service. ${ }^{, 736}$ Rather than judging the continued existence of patronage as a failure, it is important to consider what this says about Canadian state formation. Letters requesting and discussing patronage appointments show how personal and partisan issues remained part of political rhetorics. These letters frequently used emotional expressions as the rhetorical basis of the claim.

Throughout this professionalization of the civil service, what constituted a deserving applicant changed. Social expectations confronted and interacted with changing political definitions. Within this contested terrain, expressions of emotions were used to establish a claim on a politician. Ideas of loyalty, friendship, and revenge were

\footnotetext{
${ }^{735}$ Ibid.

${ }^{736}$ Doherty, Slaves of the Lamp. 17.
} 
used in requests for appointments. Framing letters in terms of social anxieties demonstrated that the applicant understood and fit the expectations of a deserving applicant, while simultaneously showing the exceptional, and sometimes dire, circumstances that caused them to seek assistance. Emotional language in patronage requests demonstrated these shifting social and political ideas. Rather than a progression from corrupt to democratic politics, or from irrational to rational administration, these processes reflect a series of negotiations, adaptations, and struggles between the technical and the personal in Canadian state formation. 


\section{Chapter 8}

\section{Conclusion}

Patronage has a long and multifaceted history in Canadian politics. It has been used as a tool to reward party support, as a weapon to punish opponents, and as a strategy to extend party goals into the different regions across the nation. It has been supported as a legitimate form of governing and challenged as a form of corruption that stood in the way of bureaucratic progress. These political and administrative histories are welldocumented. ${ }^{737}$ Patronage's social and cultural histories are less well known. The reforms of the 1880 s and 1890 s drew freely from transnational ideas on business, industry, politics, and administration. These were issues about how to staff, monitor, and discipline the civil service. They were also questions about to whom the civil service was accountable and how the state apparatus was defined. Central to these debates was how to imagine the ideal civil servant. This abstraction largely ignored the actual people who wanted positions in this apparatus. The people who sought these appointments, however, were more than passive participants in this culture. In writing letters asking for jobs, these applicants wrote about their lives, their own politics, and their own understanding of how the civil service should work.

\footnotetext{
${ }^{737}$ Gordon T Stewart, The Origins of Canadian Politics: A Comparative Approach (Vancouver: UBC Press, 1986); S.J.R. Noel, Patrons, Clients, Brokers: Ontario Society and Politics, 1791-1896 (Toronto: University of Toronto Press, 1990); Jeffrey Simpson, Spoils of Power: The Politics of Patronage (Toronto: Harper Collins, 1988); Ken Rasmussen, "Administrative Reform and the Quest for Bureaucratic Autonomy: 1867-1918," Journal of Canadian Studies, 29:3 (1994): 45-62; David E. Smith, "Patronage in Britain and Canada: An Historical Perspective," Journal of Canadian Studies 22:2 (1987): 34-54; O.P. Dwivedi and John Meisel, eds., The Administrative State in Canada: Essays in Honour of J.E. Hodgetts (Toronto: University of Toronto Press, 1982); O. P. Dwivedi, Mau, Tim A. Sheldrick, and Byron M., eds. The Evolving Physiology of Government: Canadian Public Administration in Transition (Ottawa: University of Ottawa Press, 2009).
} 
The debates over civil service reform and patronage highlight the ironies of state formation. Canada's civil service was contested and constructed both from above and from below. Patronage was a tool to protect dominant partisan interests, but it was also a tool that certain citizens used to improve their own circumstances. This patronage system coexisted with bureaucratic reforms throughout the 1880s and 1890s. In this period, reformers, and at times politicians, wanted to remake the civil service into an institution that would reward the self-governing, public men and that would follow business practices. At the same time, politicians continued to benefit from patronage. It was a useful tool to maintain partisan networks. For the ruling party, it was not in their interest to eliminate patronage. Even as they promoted themselves as modernizing reformers, having an entrance examination rather than a competitive one allowed partisan control over the appointment process. One of the reasons that patronage remained a useful political strategy was that the electorate continued to seek it. Even after politicians began publicly calling for reforms, people still wrote letters asking for appointments. For those seeking jobs, demonstrating party and community credentials remained a fruitful way to interact with politicians. There was not a straight path from patronage to bureaucracy, or from corruption to democracy. These ideas overlapped, informing each other as politicians and job-seekers both attempted to navigate the changing political culture.

Political rhetorics have histories. Terms such as 'professionalism,' 'democracy,' 'efficiency,' and 'independence' are often poorly defined in political debates - this is a political strategy. As short-story writer and essayist Jorge Luis Borges wrote, "ambiguity is richness." ${ }^{738}$ By using rich but vague rhetoric, politicians were less tied to a platform

\footnotetext{
${ }^{738}$ Jorge Luis Borges, "Pierre Menard, Author of the Quixote," in Labyrinths: Selected Stories and Other Writings, Donald A. Yates ad James E. Irby, eds., (New York: New Direction Publishing, 1962, 2007), 42.
} 
than if they were precise. Part One of this dissertation explores the sometimes contradictory positions taken up by politicians. Following the federal election of 1878 reformers urged the out-going Liberal government to reward its supporters, while Tories suggested that the government had lost the confidence of the electorate and therefore lost the right to benefit from the spoils system. Once the Conservative Party returned to power its members attempted to limit the reforms to the appointment process. Chapter Three explored how William Kingsford relied on both his professional independence and his political connections to contest his dismissal by Hector Langevin. In making the details of his case public, Kingsford appealed to an authority outside of parliament - the democratic public - while still asking influential politicians to overturn his case.

While the rhetoric of reform was often vague, the development of these terms is also a history of privilege. As outlined in the Reports of the Civil Service Commissioners, a permanent, non-partisan civil service was constructed as being made up by healthy, middle-class, relatively young men. Women, the elderly, the sick, and the injured were administered out of the civil service. The Report of 1892 (discussed in Chapter Four) showed that even when women performed tasks satisfactorily and 'efficiently' they were imagined as being less suited than men in the offices of Canada's administration because of assumptions about their bodies and their characters.

The letters asking for patronage, explored in Part Two, suggest that the changing constructions of ideal civil servants and the professional bureaucracy were not uniformly accepted by the population. If, as Gordon Stewart notes, nineteenth-century Canadian politics were "explicitly about patronage," then the letters asking for appointments were 
political documents. ${ }^{739}$ The construction of what makes a suitable public servant was addressed in a range of ways by those seeking appointments. The letters discussed in Chapter Five both reinforced and challenged the constructions of independent public manhood. These applicants attempted to demonstrate their ability to govern themselves the same ability that qualified them to govern others. ${ }^{740}$ This indicates that in the minds of patrons and clients in the Victorian era, patronage was thought of alongside efficient, democratic practices, not as anathema to them. People writing about their bodies or making emotive and sentimental claims, the subjects of Chapter Six and Seven respectively, found alternative ways to participate in this political culture. The rational rhetoric drawn from business practices and political economy existed alongside references to loyalty, friendship, and, at times, desperation.

Ideas about the efficient management of politics and society were central to nineteenth-century government. According to Michel Foucault, the intense changes in this period "gave rise to a certain way of thinking, reasoning, and calculating." civil service was one of the subjects rethought and re-ordered in this period. To whom it was responsible, how it was managed, and what kind of people it should hire were debated in political theatres, in public documents, and in private letters asking for appointments. As the statements made about the civil service and the letters asking for patronage show, this rationality was also a way of speaking and writing. Demonstrating self-government was a rhetorical strategy. These strategies were performed in traditional

\footnotetext{
${ }^{739}$ Stewart, The Origins of Canadian Politics, 31. Emphasis in original.

${ }^{740}$ Michel Foucault, "Governmentality," in Graham Burchell, Colin Gordon and Peter Miller, eds., The Foucault Effect: Studies in Governmentality (Chicago: University of Chicago Press, 1991), 91-92; Mitchell Dean, Governmentality: Power and Rule in Modern Society (London, Sage Publications, 1999), 12.

${ }^{741}$ Michel Foucault, Security, Territory and Population: Lectures at the Collège de France, 1977-78, edited by Michel Senellart, translated by Graham Burchell (New York: Palgrave Macmillan, 2007), 286.
} 
political history documents - Hansards, commission reports, and newspapers - as well as in patronage letters. Examining these types of statements together provides a fuller understanding of nineteenth-century Canadian politics.

The origins of this political system were not solely in Central Canadian practices, nor in administrative issues, nor in partisan efforts to consolidate political control. The management of the civil service, debated over and over, was not an isolated, administrative question. How to define the civil service was based on an ongoing series of negotiations between politicians, reformers, and job-seekers. Reformers drew on political practices from Britain, Indian, and the Unites States. They self-consciously presented these ideas as a movement towards a more democratic system, where professional managers, instead of politicians, governed the appointment process. This too was a rhetorical strategy, presenting their goals as tested, modern, and authoritative. The letters asking for appointments also contributed to, challenged, and drew from this rhetoric. Derek Sayer notes: "state forms or enactments do not merely constrain. They may also empower and enable.... Individuals and groups may creatively adapt and use the forms through which, on another level, they are confined and constrained. ${ }^{742}$ As applicants attempted to demonstrate that they governed themselves, while asking for help, they participated in this construction of the civil servant. Even if an application did not fit - if a body was failing or a connection to a patron was sentimental - requesting patronage was still a process of fitting their lives within the dominant rationality.

This dissertation's emphasis on the government of both the civil service and those attempting to present themselves as worthy of appointment introduces a range of avenues

\footnotetext{
${ }^{742}$ Derek Sayer, "Everyday Forms of State Formation: Some Dissident Remarks on 'Hegemony"' in Gilbert M. Joseph and Daniel Nugent, eds., Everyday Forms of State Formation: Revolution and the Negotiation of Rule in Modern Mexico (Durham: Duke University Press, 1994), 326.
} 
for further research. One possible exploration is the knowledge-producing practices of the Civil Service Lists. These lists recorded a range of descriptive information - age, religion, date of appointment, promotion history, salary, title, etc. - about the workers in different government departments. How these lists were produced, maintained, read, and archived could shed insight on the technologies of government used in the Canadian bureaucracy ${ }^{743}$ Those interested in biography and the relation between individual lives and state formation could ask another set of questions about the Civil Service Commissioners themselves. How did the commissioners' backgrounds, relationships, party connections, and personal interests affect their reports and their recommendations? Similar questions could be asked of George Elliott Casey's reforming work. ${ }^{744}$

The question of distance, central to the uneven formation of the Canadian state could be extended to how the culture and practices of patronage were instituted in Canada's West. This opens Canada's political and administrative history to the insights of postcolonial scholarship. The ideal civil servant was taken to be a white, propertied, man. In exploring the administration and settlement the West and Northwest, these assumptions of administrative whiteness came into more regular contact and conflict with the population they attempted to govern. ${ }^{745}$ In the 1892 Report a Dominion Land

\footnotetext{
${ }^{743}$ These type of questions run through Bruce Curtis's work. See, for example, "The Canada 'Blue Books' and the Administrative Capacity of the Canadian State, 1822-1867," Canadian Historical Review, 74:4 (1993): 535-565.

${ }^{744}$ The interaction of personal, business, and legal interests in processes of state formation is explored in Brian Young, The Politics of Codification: The Lower Canadian Civil Code of 1866 (Montreal and Kingston: McGill-Queen's University Press, 1994). Bruce Curtis, in The Politics of Population: State Formation, Statistics, and the Census of Canada, 1840-1875 (Toronto: University of Toronto Press, 2001) likewise explores the roles of head enumerators in the creation of the census.

${ }^{745}$ Adele Perry has already outlined the role of race and gender in British Columbia's joining Canada. This political history was involved regulating mixed-race relationships and providing acceptable, gender and racial behaviour in the West. Adele Perry, On the Edge of Empire: Gender, Race and the Making of British Columbia, 1849-1871 (Toronto: University of Toronto Press, 2001). Regarding policing, Keith D Smith has explored the importance of regulating and defining racial characteristics in the establishment of a liberal order in Western Canada. Keith D. Smith, Liberalism, Surveillance, and Resistance: Indigenous
} 
surveyor highlighted the interaction of race and class. Many of the assistants, he explained, were "the sons of gentlemen, who expect to be treated as equals, and it creates discontent in the camp, because they are practically holding the position of labourers." He then complained that "they are not scientific; they know nothing of the business...they are not as much use to us as an ordinary half-breed or labourer would be." ${ }^{746}$ In addition to the actual work being done, it would be interesting to see if and how race was treated in letters requesting administrative positions in Western Canada.

Chronologically this dissertation concludes at the end of the nineteenth-century; however, its insights invite further work on twentieth-century political culture. As much administrative history and public policy literature suggests, the civil service was more autonomous and regulated in this period. ${ }^{747}$ There continued, however, to be struggles about the civil service's role and responsibilities. How these struggles were waged, how the terms of debate were defined, and how the population participated in the new context could all be further examined. People have written on the history and the triumphs of the Public Service Commission. ${ }^{748}$ There are still questions to be asked about its everyday practices, internal rationality, references, and vocabulary. The public service, like the image of the state, was not made once and for all. Rather it was in-formation, being

Communities in Western Canada, 1877-1927 (Athabasca: AU Press, 2009). The relationship between law, order, race and liberalism in British Columbia is also explored by Tina Loo, Making Law, Order, and Authority in British Columbia, 1821-1871 (Toronto: University of Toronto Press, 1994).

${ }^{746}$ Canada, Parliament, Sessional Papers of the Dominion of Canada, vol. 11, $7^{\text {th }}$ Parliament, $2^{\text {nd }}$ Session (Ottawa: S.E. Dawson, 1892, )104.

${ }^{747}$ Luc Juillet and Ken Rasmussen, Defending a Contested Ideal: Merit and the PSC of Canada, 1908-2008 (Ottawa: University of Ottawa Press, 2008); Public Service Commission of Canada, The 100 Years of the Public Service Commission of Canada, 1908-2008 (Ottawa: Public Service Commission of Canada, 2008).

${ }^{748}$ Ken Rasmussen, "Administrative Reform and the Quest for Bureaucratic Autonomy: 1867-1918," Journal of Canadian Studies, 29:3 (1994): 45-62; Bill Doherty, Slaves of the Lamp: A History of the Federal Civil Service Organizations, 1865-1924 (Victoria, BC: Orca Books Publishers, 1991). 
remade as it was challenged and as it was celebrated. This process does not end - rather there is a continued movement between ideas and practices. What state practices do is connected to how and for whom people think politics should work.

The role, autonomy, and self-image of civil servants continue to be contested and challenged. How to have a professional, non-partisan administration is still a question that occupies much discussion of public policies. Likewise, what constitutes politics, partisanship, and professionalism is still debated. Contemporary commentators would be well-served to define these terms with more precision and reflexivity. The terms that are convincing on Parliament Hill are not necessarily the same that are required in the communities where those policies will be enacted. In the nineteenth century many who sought patronage did so not out of corruption or greed, but because that was how politics worked. Reformers in Ottawa challenged these ideas, but this history of Canada's bureaucracy is not only theirs. This was a history of abstraction and generalization. It was also a history that was challenged when confronted with local and personal circumstances that did not fit this centralized image.

As in the nineteenth-century, Canadian politics continues to experience tensions between the material and the abstract, the local and the general. The rhetoric used to navigate these tensions is neither innocent nor natural. Rhetoric, whether by professional civil servants, electioneering partisans, or even those seeking patronage, is politics itself. 


\section{Bibliography}

\section{Primary Sources}

\section{Archives of Ontario}

Alexander Campbell Fonds. F23-1.

William Kingsford Fonds. F 1016.

William Bain Scarth Fonds. F 67.

\section{Library and Archives Canada}

Sir George-Étienne Cartier Fonds. MG 27 ID 4.

Census of 1871 (online).

http://www.bac-lac.gc.ca/eng/census/1871/Pages/about-census.aspx. Last accessed 10 July 2013.

Census of New Brunswick, 1851 (online). http://www.collectionscanada.gc.ca/databases/census-1851/index-e.html. Last accessed 10 July 2013.

Department of Justice Fonds. RG 13.

Department of Militia and Defence Fonds. RG 9.

Sir John A. Macdonald Fonds. MG 26 A.

Sir Samuel Leonard Tilley Fonds. MG 27 ID 15.

Sir Charles Tupper Fonds. MG 26 F.

\section{Provincial Archives of Nova Scotia}

W.S. Fielding Fonds. MG 2.

Provincial Secretary's Papers. RG 7.

\section{Government Documents}

Canada. Board of Civil Service Examiners. Rules and Regulations of the Board of Civil Service Examiners. Ottawa, 1882. 
Canada. Parliament. Debates of the House of Commons, $3^{\text {rd }}$ Parliament, $5^{\text {th }}$ Session. Ottawa: Maclean, Roger, 1878.

_ _ _ Debates of the House of Commons, 4th Parliament, 1st Session, 1879, vol.1-2. Ottawa: Citizen Print. and Pub. Co., 1879.

- - - Debates of the House of Commons, $4^{\text {th }}$ Parliament, $3^{\text {rd }}$ Session. Ottawa: MacLean, Roger, 1881.

- - - Debates of the House of Commons, $4^{\text {th }}$ Parliament, $4^{\text {th }}$ Session. Ottawa: Maclean, Roger, 1882.

_ — - Debates of the House of Commons, $5^{\text {th }}$ Parliament, $1^{\text {st }}$ Session. Ottawa: Maclean, Roger, 1883.

- - - Debates of the House of Commons, $5^{\text {th }}$ Parliament, $2^{\text {nd }}$ Session. Ottawa: MacLean, Roger, 1884.

- - - Debates of the House of Commons, $5^{\text {th }}$ Parliament, $3^{\text {rd }}$ Session. Ottawa: Maclean, Roger, 1885.

- - - Debates of the House of Commons, $6^{\text {th }}$ Parliament, $1^{\text {st }}$ Session. Ottawa: MacLean, Roger, 1887.

- - - Debates of the House of Commons, $6^{\text {th }}$ Parliament, $2^{\text {nd }}$ Session. Ottawa: Hunter Rose, 1888.

- - - Debates of the House of Commons, $6^{\text {th }}$ Parliament, $4^{\text {th }}$ Session. Ottawa: B. Chamberlain, 1890.

- _ - Debates of the House of Commons, $7^{\text {th }}$ Parliament, $2^{\text {nd }}$ Session. Ottawa: S.E. Dawson, 1892.

_ - - Sessional Papers of the Dominion of Canada, Vol. 10, 4th Parliament, $3^{\text {rd }}$ Session. Ottawa: Maclean, Roger, 1881.

- - - Sessional Papers of the Dominion of Canada, vol. 11, $7^{\text {th }}$ Parliament, $2^{\text {nd }}$ Session. Ottawa: S.E. Dawson, 1892.

- - - Sessional Papers of the Dominion of Canada, Vol. 9, $7^{\text {th }}$ Parliament, $3^{\text {rd }}$ Session. Ottawa: S.E. Dawson, 1893.

_ - - Sessional Papers of the Dominion of Canada, Vol. 10, $7^{\text {th }}$ Parliament, $5^{\text {th }}$ Session. Ottawa: S.E. Dawson, 1895.

— — - Statutes of Canada, $1^{\text {st }}$ Session, $1^{\text {st }}$ Parliament. Ottawa: Malcolm Cameron, 1868. 


\section{Printed Primary Sources}

Daily Evening News. Saint John, New Brunswick, 1877-1881.

Kingsford, William. Mr. Kingsford and Sir H. Langevin, The Case Considered with the Official Correspondence: A Memoir for the Historian of the Future. Toronto: R.G. McLean, 1882.

— — - The History of Canada, volumes 1-10. Toronto: Rowsell \& Hutchison, 1887-1898.

Lankester, E. Ray. "Competitide [sic] Examination.” The Universal Review, November 1888: 372-413.

Lord Dufferin. Speeches and Addresses of the Right Honourable Frederick Temple Hamilton, Earl of Dufferin. Edited by Henry Milton. London: William Cowes and Sons Ltd, 1882.

Mill, John Stuart. Utilitarianism and On Liberty, Including Mill's Essay on Bentham and selections from the writings of Jeremy Bentham and John Austin. Edited by Mary Warnock. London: Blackwell Publishing, 2003.

National Post. Toronto, 7 December 2011.

Reade, John. “Canadian Histories.” Canadiana. 1:1(1889): 3-13.

Shannon, R.W. "A Canadian Historian: A Sketch for Mr. Kingsford.” The Canadian Magazine. 12:3 (1899): 191-195.

Smith, Goldwin. "The Political History of Canada." The Nineteenth Century and After: A Monthly Review. 20:113 (1886): 14-32.

Stead, Alfred and John Stead, editors. "Women in the Civil Service." The Review of Reviews. 47:277 (1913): 71-71.

The Dominion Illustrated. Volume 5, no. 128. 13 December 1890.

The Globe. Toronto, 1871-1892.

"The Indian Civil Service: Its Rise and Fall." John Blackwood, editor. Blackwood's Edinburgh Magazine. 89:545 (1861): 261-276. 


\section{$\underline{\text { Secondary Sources }}$}

Abrams, Philip. "Notes on the Difficulty of Studying the State." Journal of Historical Sociology 1:1 (1988): 58-89.

Adamoski, Robert, Dorothy E. Chunn and Robert Menzies, editors. Contesting Canadian Citizenship: Historical Readings. Peterborough, Ont.: Broadview Press, 2002.

Alaya, Flavia. "Victorian Science and the 'Genius' of Woman." Journal of the History of Ideas 38:2 (1977): 261-280.

Aron, Cindy Sondik. Ladies and Gentlemen of the Civil Service: Middle-Class Workers in Victorian America. Oxford: Oxford University Press, 1987.

Axelrod, Paul. The Promise of Schooling: Education in Canada, 1800-1914. Toronto: University of Toronto Press, 1997.

Barry, Andrew, Thomas Osborne, and Nikolas Rose, editors. Foucault and Political Reason: Liberalism, Neo-Liberalism, and Rationalities of Government. Chicago: University of Chicago Press, 1996.

Bayly, C.A. and D.H.A. Kolff, editors. Two Colonial Empires: Comparative Essays on the History of India and Indonesia in the Nineteenth Century. Century. Lancaster: Leiden University Press, 1986.

Bederman, Gail. Manliness and Civilization: A Cultural History of Gender and Race in the United Sates, 1880-1917. Chicago: University of Chicago Press, 1995.

Bélanger, Damien-Claude. Prejudice and Pride: Canadian Intellectuals Confront the United States, 1891-1945. Toronto: University of Toronto Press, 2011.

Belisle, Donica Retail Nation: Department Stores and the Making of Modern Canada. Vancouver: UBC Press, 2011.

Bellamy, David, Jon Pammett, and Donald Rowat, editors. The Provincial Political Systems: Comparative Essays. Toronto: Methuen, 1976.

Bernard, Jean-Paul. Les Rouges: libéralisme, nationalisme et anticléricalisme au milieu du XIXe siècle. Montreal: Les presses de l’Université du Québec, 1971.

Bhabha, Homi K. The Location of Culture. New York and London: Routledge, 1994.

Bitterman, Rusty. Rural Protest on Prince Edward Island: From British Colonization to the Escheat Movement. Toronto: University of Toronto Press, 2006. 
Blackhouse, Constance. Petticoats and Prejudice: Women and the Law in NineteenthCentury Canada. Toronto: The Osgoode Society, Women's Press, 1991.

Bliss, Michael. Northern Enterprise: Five Centuries of Canadian Business. Toronto: McClelland and Stewart, 1987.

Borges, Jorge Luis. Labyrinths: Selected Stories and Other Writings. Edited by Donald A. Yates and James E. Irby. New York: New Direction Publishing, 1962, 2007.

Boyer, Kate. "“Miss Remington' goes to work: Gender, Space, and Technology at the Dawn of the Information Age." The Professional Geographer 56:2 (2004): 201212.

Bradbury, Bettina. Wife to Widow: Lives, Laws, and Politics in Nineteenth-Century Montreal. Vancouver: UBC Press, 2011.

_ _ _ Working Families: Age, Gender and Daily Survival in Industrial Montreal. Toronto: McClelland and Stewart, 1993.

Breton, Albert. "Patronage and Corruption in Hierarchies." Journal of Canadian Studies 22:2 (1987): 19-33.

Brownlee, Peter John. "Ophthalmology, Popular Physiology, and the Market Revolution in Vision, 1800-1850.” Journal of the Early Republic 28:4 (2008): 597-626.

Burchell, Graham, Colin Gordon, and Peter Miller, eds. The Foucault Effect: Studies in Governmentality. Chicago: University of Chicago Press, 1991.

Calhoun, Craig, editor. Habermas and the Public Sphere. Cambridge, Mass: MIT Press, 1992.

Campbell, David and Michael Dillon, editors., The Political Subject of Violence. Manchester: Manchester University Press, 1993.

Certeau, Michel de. The Practice of Everyday Life. Translated by Steven Rendall. Berkeley: University of California Press, 1984.

Chakrabarty, Dipesh. Habitations of Modernity: Essays in the Wake of Subaltern Studies. Chicago: University of Chicago Press, 2007.

Chambers, Lori. Married Women and Property Laws in Victorian Ontario. Toronto: University of Toronto Press, 1997.

Chatterjee, Partha. Nationalist Thought and the Colonial World: A Derivative Discourse. London: Zed Books, 1986. 
Chen, Xiaobei. Tending the Gardens of Citizenship: Child Saving in Toronto, 1880s1920s. Toronto: University of Toronto Press, 2005.

Christie, Nancy, editor. Transatlantic Subjects: Ideas, Institutions, and Social Experience in Post-Revolutionary British North America. McGill-Queen's University Press, 2008.

Cohen, William A. and Ryan Johnson, editors. Filth: Dirt, Disgust, and Modern Life. Minneapolis: University of Minnesota Press, 2005.

Constant, Jean-François and Michel Ducharme, editors. Liberalism and Hegemony: Debating the Canadian Liberal Revolution. Toronto: University of Toronto Press, 2009.

Cooper, John Irwin. "The Origins and Early History of the Montreal City and District Bank.” CCHA Report 13 (1945-46): 15-25.

Corn, Jacqueline Karnell. Response to Occupational Health Hazards: A Historical Perspective. New York: Van Nostrand Reinhold, 1992.

Corrigan, Philip. Social Forms/ Human Capacities: Essays in Authority and Difference. London: Routledge, 1990.

_ _ _, editor. Capitalism, State Formation and Marxist Theory. London: Quartet Books, 1980.

- _ — and Bruce Curtis. "Education, Inspection and State Formation: A Preliminary Statement." Historical Papers/ Communications historiques 20:1 (1985): 156171.

- - — and Derek Sayer. The Great Arch: English State Formation as Cultural Revolution. Oxford: Basil Blackwell, 1985.

Courville, Serge. Rêve d'empire: le Québec et le rêve coloniale. Ottawa: Les Presses de l'Université d'Ottawa, 2000.

Creighton, Donald. John A. Macdonald, volumes 1-2. Toronto: The MacMillan Company of Canada, 1952-1955.

Curtis, Bruce. "On the Local Construction of Statistical Knowledge: Making Up the Census of the Canadas." Journal of Historical Sociology 7:4 (1994): 416-434.

- - - "Representation and State Formation in the Canadas, 1790-1850." Studies in Political Economy 28 (1989): 59-87. 
_ _ _. "The Canada 'Blue Books' and the Administrative Capacity of the Canadian State, 1822-1867.” Canadian Historical Review 74:4 (1993): 535-565.

_ _ - " “The Most Splendid Pageant Ever Seen': Grandeur, the Domestic, and Condescension in Lord Durham's Political Theatre." Canadian Historical Review 89:1 (2008): 55-88.

- - - The Politics of Population: State Formation, Statistics, and the Census of Canada, 1840-1875. Toronto: University of Toronto Press, 2001.

_ _ _. True Government by Choice Men: Inspection, Education and State Formation in Canada West. Toronto: University of Toronto Press, 1992.

Daston, Lorraine and Peter Galison. "The Image of Objectivity." Representations 40, Special Issue (1992): 81-128.

Davidoff, Leonore. "Class and Gender in Victorian England: The Diaries of Arthur J. Munby and Hannah Cullwick." Feminist Studies 5:1 (1979): 86-141.

— — - and Catherine Hall. Family Fortunes: Men and Women of the English Middle Class, 1780-1850. New York: Routledge, 1987, 2002.

Dawson, R. MacGregor. The Civil Service of Canada. Oxford: Oxford University Press, 1929.

Dean, Mitchell. Governmentality: Power and Rule in Modern Society. London, Sage Publications, 1999.

Decker, William Merrill. Epistolary Practices: Letter Writing in America Before Telecommunications. Chapel Hill: University of North Carolina Press, 1998.

den Otter, A.A. The Philosophy of Railways: The Transcontinental Railway Idea in British North America. Toronto: University of Toronto Press, 1997.

Dictionary of Canadian Biography. University of Toronto and Univserité Laval. http://www.biographi.ca/en/index.php. Last accessed 4 July 2013.

Dillon, Lisa. The Shady Side of Fifty: Age and Old Age in Late Victorian Canada and the United States. Montreal and Kingston: McGill-Queen's University Press, 2008.

Doherty, Bill. Slaves of the Lamp: A History of the Federal Civil Service Organizations, 1865-1924. Victoria, BC: Orca Books Publishers, 1991. 
Ducharme, Michel. Le concept de liberté au Canada à l'époque des Révolutions atlantiques, 1776-1838. Montreal and Kingston: McGill-Queen's University Press, 2010.

_ _ _. "Penser le Canada." Revue d'Histoire de l'Amérique Française $56: 3$ (2001): $356-81$.

Durbach, Nadja. Bodily Matters: The Anti-Vaccination Movement in England, 18531907. Durham: Duke University Press, 2005.

Dussault, Gabriel. Le Curé Labelle: messainisme, utopie et colonization au Québec, 1850-1900. Montreal: Hurtubisie, 1983.

Dwivedi, O.P. and John Meisel, editors. The Administrative State in Canada: Essays in Honour of J.E. Hodgetts. Toronto: University of Toronto Press, 1982.

Dwivedi, O. P. Mau, Tim A. Sheldrick, and Byron M., editors. The Evolving Physiology of Government: Canadian Public Administration in Transition. Ottawa: University of Ottawa Press, 2009.

Elias, Norbert. Essays III: On Sociology and the Humanities. Edited by Richard Kilminster and Stephen Mennell. Dublin: University College Dublin Press, 2009.

_ — - The Civilizing Process: Sociogenetic and Psychogenetic Investigations. Translated by Edmund Jephcott. London: Blackwell Publishing, 1939, 2000.

Elliott, Bruce S., David A. Gerber, and Suzanne M. Sinke, editors. Letters Across Borders: The Epistolary Practices of International Immigrants. New York: Palgrave MacMillan, 2006.

Eustace, Nicole. Passion is the Gale: Emotion, Power, and the Coming of the American Revolution. Chapel Hill: University of North Carolina Press, 2008.

Fecteau, Jean-Marie. La liberté du pauvre: crime et pauvreté au XIXe siècle québécois. Montreal: VLB éditeur, 2004.

Ferry, Darren. Uniting in Measures of Common Good: The Construction of Liberal Identities in Central Canada, 1830-1900. Montreal and Kingston" McGillQueen's University Press, 2008.

Finkel, Alvin. Social Policy and Practice in Canada: A History. Wilfrid Laurier University Press, 2006.

Fish, Carl Russel. The Civil Service and the Patronage. New York: Russell and Russell Inc, 1904, 1963. 
Forbes, E.R. Challenging the Regional Stereotypes: Essays on the $20^{\text {th }}$ Century Maritimes. Fredericton: Acadiensis Press, 1989.

- _ - and D.A. Muise eds. The Atlantic Provinces in Confederation. Toronto: University of Toronto Press, and Fredericton: Acadiensis Press, 1993.

Foucault, Michel. Discipline and Punish: The Birth of the Prison. Translated by Alan Sheridan. New York: Vintage Books, 1979.

_ _ _. Power/Knowledge: Selected Interviews and Other Writings, 19721977. Edited by Colin Gordon. New York: Pantheon Books, 1980.

- - - Security, Territory, Population: Lectures at the Collège de France, 1977-1978. Edited by Michel Senellart. Translated by Graham Burchell. New York: Palgrave Macmillan, 2004.

_ — - The Birth of Biopolitics: Lectures at the Collège de France, 19781979. Edited by Michel Sennart. Translated by Graham Burchell. New York: Palgrave, 2008.

Fyson, Donald. Magistrates, Police and People: Everyday Criminal Justice in Quebec and Lower Canada, 1764-1837. Toronto: The Osgoode Society for Canadian Legal History, University of Toronto Press, 2006.

Garner, John. The Franchise and Politics in British North America, 1755-1867. Toronto: University of Toronto Press, 1969.

Gidney, R.D. and W.P.J. Millar, Professional Gentlemen: The Professions in NineteenthCentury Ontario. Toronto: University of Toronto Press, 1994.

Gilbert, Pamela K. The Citizen's Body: Desire, Health, and the Social in Victorian England. Columbus: The Ohio State University Press, 2007.

Gordon, Alan. "Patronage, Etiquette, and the Science of Connection: Edmund Bristol and Political Management, 1911-1921." Canadian Historical Review 80:1 (1999): 133.

_ — - The Hero and the Historians: Historiography and the Uses of Jacques Cartier. Vancouver: UBC Press, 2010.

Graebner, William. A History of Retirement: The Meaning and Function of an American Institution 1885-1978. New Haven: Yale University Press, 1980.

Granatstein, Jack. The Ottawa Men: The Civil Service Mandarins, 1935-1957. Toronto: Oxford University Press, 1982. 
Greer, Allan. The Patriots and the People: The Rebellion of 1837 in Rural Lower Canada. Toronto: University of Toronto Press, 1993.

_ _ — - and Ian Radforth, eds., Colonial Leviathan: State Formation in MidNineteenth-Century Canada. Toronto: University of Toronto Press, 1992.

Guildford, Janet and Suzanne Morton, eds. Separate Spheres: Women's Worlds in the $19^{\text {th }}$-Century Maritimes. Fredericton: Acadiensis Press, 1994.

Gullette, Margaret Morganroth. Aged By Culture. Chicago: The University of Chicago Press, 2004.

Gunn, Simon and James Vernon, editors. The Peculiarities of Liberal Modernity in Imperial Britain. Berkeley: University of California Press, 2011.

Hacking, Ian. The Taming of Chance. Cambridge: Cambridge University Press, 1990.

Hannah, Matthew G. Governmentality and the Mastery of Territory in NineteenthCentury America. Cambridge: Cambridge University Press, 2000.

Hansen, Thomas Blom and Finn Stepputat, editors. States of Imagination: Ethnographic Explorations of the Postcolonial State. Durham: Duke University Press, 2001.

Heaman, E.A. The Inglorious Arts of Peace: Exhibitions in Canadian Society during the Nineteenth Century. Toronto: University of Toronto Press, 1999.

Hearn, Jeff. Men in the Public Eye: The Construction and Deconstruction of Public Men and Public Patriarchies. London: Routledge, 1992.

Hemphill, C. Dallett. Bowing to Necessities: A History of Manners in America, 16201860. Oxford: Oxford University Press 1999.

Henderson, George Fletcher. Federal Royal Commissions in Canada, 1867-1966: A Checklist. Toronto: University of Toronto Press, 1967.

Hodgetts, J.E. Pioneer Public Service: An Administrative History of United Canada, 1841-1867. Toronto: University of Toronto Press, 1955.

_ _ _ . "Review of The Ottawa Men.” International Journal 37:4 (1982): 636-638.

_ _ _ . The Canadian Public Service: A Physiology of Government, 1867-1870. Toronto: University of Toronto Press, 1973.

Hoogenboom, Ari. Outlawing the Spoils: A History of the Civil Service Reform Movement, 1865-1883. Urbana: University of Illinois Press, 1961. 
Horner, Dan. “'Shame on You as Men!': Contesting Authority in the Aftermath of Montreal's Gavazzi Riot, 1853." Histoire sociale/ Social History 44:87 (2011): 29-52.

_ _ _ _ "Solemn Processions and Terrifying Violence: Spectacle, Authority and Citizenship during the Lachine Canal Strike of 1843." Urban History Review/ Revue d'histoire urbaine 38.2 (2010): 36-47.

Iacovetta, Franca. Gatekeepers: Reshaping Immigrant Lives in Cold War Canada. Toronto: Between the Lines, 2006.

Johnson, J.K. and Bruce G. Wilson, editors. Historical Essays on Upper Canada, New Perspectives. Ottawa: Carleton University Press, 1989.

Joseph, Gilbert M. and Daniel Nugent, editors. Everyday Forms of State Formation: Revolution and the Negotiation of Rule in Modern Mexico. Durham: Duke University Press, 1994.

Joyce, Patrick. The Rule of Freedom: Liberalism and the Modern City. London: Verso, 2003.

Juillet, Luc and Ken Rasmussen. Defending a Contested Ideal: Merit and the PSC of Canada, 1908-2008. Ottawa: University of Ottawa Press, 2008.

Kasson, John F. Houdini, Tarzan, and the Perfect Man: The White Male Body and the Challenge of Modernity in America. New York: Hill and Wang, 2001.

Kealey, Gregory S. Toronto Workers Respond to Industrial Capitalism, 1867-1892. Toronto: University of Toronto Press, 1980.

Kirk-Greene, Anthony. On Crown Service: A History of HM Colonial Services and Overseas Civil Services, 1837-1997. London: I.B. Taurus Publishers, 1999.

Lanning, Robert. The National Album: Collective Biography and the Formation of the Canadian Middle Class. Ottawa: Carleton University Press, 1996.

Lears, T.J. Jackson. No Place of Grace: Antimodernism and the Transformation of American Culture, 1880-1920. New York: Pantheon Books, 1981.

Legg, Stephen. Spaces of Colonialism: Delhi's Urban Governmentalities. Oxford: Blackwell Publishing, 2007.

Lemieux, Vincent. Le Patronage politique: une étude comparative. Québec: Les presses de l’Université de Laval, 1977. 
Little, J.I., Nationalism, Capitalism, and Colonization in Nineteenth Century Quebec: The Upper St. Francis District. Montreal and Kingston: McGill-Queens University Press, 1990.

Loo, Tina. Making Law, Order, and Authority in British Columbia, 1821-1871. Toronto: University of Toronto Press, 1994.

Mah, Harold. "Phantasies of the Public Sphere: Rethinking the Habermas of Historians." The Journal of Modern History 72:1 (2000): 153-182.

Maheswari, Shriram. The Evolution of Indian Administration. Agra, India: Lakshmi Narain Agarwal, 1970.

Marcus, George E. The Sentimental Citizen: Emotion in Democratic Politics. University Park, PA: Pennsylvania State University Press, 2002.

Marshall, Dominique. The Social Origins of the Welfare State: Québec Families, Compulsory Education, and Family Allowances, 1940-1955. Translated by Nicola Doone Danby. Waterloo: Wilfrid Laurier University Press, 2006.

Martin, Ged. "John A. Macdonald and the Bottle." Journal of Canadian Studies 40:3 (2006): 162-185.

McDonald, Robert A.J. “The Quest for 'Modern Administration': British Columbia's Civil Service, 1870s to 1940s.” BC Studies 161 (Spring 2009): 9-34.

McKay, Ian. "The Liberal Order Framework A Prospectus for a Reconnaissance of Canadian History." Canadian Historical Review 81:3 (2000): 617-645.

McKenna, Katherine M.J. A Life of Propriety: Anne Murray Powell and her Family 1755-1849. Montreal and Kingston: McGill-Queen's University Press, 1994.

McKillop, A.B. A Critical Spirit: The Thought of William Dawson LeSueur. Toronto: The Carleton Library, McClelland and Stewart Ltd, 1977.

McNairn, Jeffrey L. The Capacity to Judge: Public Opinion and Deliberative Democracy in Upper Canada, 1791-1854. Toronto: University of Toronto Press, 2000.

Melville, Herman. Great Short Works of Herman Melville. Edited by Warner Berthoff. New York: Perennial Classics, 2004.

Miller, J.R. “Anti-Catholic Thought in Victorian Canada." Canadian Historical Review 66:4 (1985): 474-494.

Mills, Sean. The Empire Within: Postcolonial Thought and Political Activism in Sixties Montreal. Montreal and Kingston: McGill-Queen's University Press, 2010. 
Miron, Janet. Prisons, Asylums, and the Public: Institutional Visiting in the Nineteenth Century. Toronto: University of Toronto Press, 2011.

Mitchell, Timothy. Colonising Egypt. Berkeley: University of California Press, 1988.

_ _ - Questions of Modernity. Minneapolis: University of Minnesota Press, 2000.

_ _ _ - Rule of Experts: Egypt, Techno-Politics, Modernity. Berkeley: University of California Press, 2002.

Morency, Jean, Helene Destrempes, Denise Merkle, and Martin Pâquet, editors. Des cultures en contact: Visions de l'Amerique du Nord francophone. Quebec: Nota Bene, 2005.

Morgan, Cecilia. "'Of Slender Frame and Delicate Appearance': The Place of Laura Secord in the Narratives of Canadian Loyalist History." Journal of Canadian Studies 5:1 (1994): 195-212.

Neocleous, Mark. Administering Civil Society: Towards a Theory of State Power. London: Macmillan Press, 1996.

_ _ _ Imagining the State. Maidenhead: Open University Press, 2003.

Nichols, Barbara and Peter Leonard, editors. Gender, Aging and the State. Montreal: Black Rose Books, 1994.

Noel, S.J.R. Patrons, Clients, Brokers: Ontario Society and Politics, 1791-1896. Toronto: University of Toronto Press, 1990.

Otter, Chris. The Victorian Eye: A Political History of Light and Vision in Britain, 18001910. Chicago: The University of Chicago Press, 2008.

Owram, Douglas. Building For Canadians: A History of the Department of Public Works, 1840-1960. Public Relations and Information Services, Public Works Canada, 1979.

_ _ - The Government Generation: Canadian Intellectuals and the State, 1900-1945. Toronto: University of Toronto Press, 1986.

Pallares-Burke, Maria Lucia. The New History: Confessions and Conversation. Cambridge: Polity Press, 2002.

Palonen, Kari. Quentin Skinner: History, Politics, Rhetoric. Cambridge: Polity Press, 2003. 
Panitch, Leo, editor. The Canadian State: Political Economy and Political Power. Toronto: University of Toronto Press, 1977.

Paquet, Gilles et Jean-Pierre Wallot. Patronage et pouvoir dans le Bas-Canada (17941812). Montreal: Les Presses du l'Université du Québec, 1973.

Piva, Michael J. "Getting Hired: The Civil Service Act of 1857." Journal of the Canadian Historical Association 3:1 (1992): 95-127.

_ _ _. "Debt, Salaries and Civil Service Reform in Pre- Confederation Canada," National History 1 (1997): 127-I38.

Perry, Adele. On the Edge of Empire: Gender, Race and the Making of British Columbia, 1849-1871. Toronto: University of Toronto Press, 2001.

Peters, John Durham. Speaking into the Air: A History of the Idea of Communication. Chicago: University of Chicago Press, 1999.

Poovey, Mary. The Proper Lady and the Woman Writer: Ideology as Style in the Works of Mary Wollstonecraft, Mary Shelley, and Jane Austen. Chicago: The University of Chicago Press, 1984.

_ _ _ Uneven Developments: The Ideological Work of Gender in Mid-Victoiran England. Chicago: The University of Chicago Press, 1988.

Porter, Theodore M. Trust in Numbers: The Pursuit of Objectivity in Science and Public Life. Princeton: Princeton University Press, 1995.

Public Service Commission of Canada. The 100 Years of the Public Service Commission of Canada, 1908-2008. Ottawa: Public Service Commission of Canada, 2008.

Raibmon, Paige. Authentic Indians: Episodes of Encounter from the Late-NineteenthCentury Northwest Coast. Durham: Duke University Press, 2005.

Rasmussen, Ken. "Administrative Reform and the Quest for Bureaucratic Autonomy: 1867-1918.” Journal of Canadian Studies 29:3 (1994): 45-62.

Rodgers, Daniel T. Atlantic Crossings: Social Politics in a Progressive Age. Cambridge, Mass: The Belknap Press of Harvard University, 1998.

Rorty, Richard, J.B. Schneewind, and Quentin Skinner, editors. Philosophy in History: Essays on the Historiography of Philosophy. Cambridge: Cambridge University Press, 1984.

Rose, Nikolas. Powers of Freedom: Reframing Political Thought. Cambridge: Cambridge University Press, 1999. 
Rose, Sonya O. Limited Livelihoods: Gender and Class in Nineteenth-Century England. Berkeley: University of California Press, 1992.

Rosenbloom, David. "The Politics-Administration Dichotomy in U.S. Historical Context." Public Administration Review 68:1 (2008): 57-60.

Roy, Fernande. Histoire des ideologies au Québec aux XIXe et XXe siècles. Montreal: Boréal, 1993.

Rudy, Jarrett. The Freedom to Smoke: Tobacco, Consumption and Identity. Montreal and Kingston: McGill-Queen's University Press, 2005.

Samson, Daniel. The Spirit of Industry and Improvement: Liberal Government and Rural-Industrial Society, Nova Scotia, 1790-1862. Montreal and Kingston: McGill-Queen's University Press, 2008.

Sayer, Derek. "A Notable Administration: English State Formation and the Rise of Capitalism.” The American Journal of Sociology 97:2 (1992): 1382-1415.

Schmidt, Steffen W., Laura Guasti, Carl H. Landé and James C. Scott, editors. Friends, Followers and Factions: A Reader in Political Patronage. Berkeley: University of California Press, 1977.

See, Scott W. Riots in New Brunswick: Orange Nativism and Social Violence in the 1840s. University of Toronto Press, 1993.

Shweder, Richard A., ed. Welcome to Middle Age and Other Cultural Fictions. Chicago: The University of Chicago Press, 1998.

Silberman, Bernard S. Cages of Reason: The Rise of the Rational State in France, Japan, the United States and Great Britain. Chicago: Chicago University Press, 1993.

Silver, A.I. The French-Canadian Idea of Confederation, 1864-1900. Toronto: University of Toronto Press, 1982.

Simpson, Jeffrey. Spoils of Power: The Politics of Patronage. Toronto: Harper Collins, 1988.

Sinha, Mrinalini. Colonial Masculinity: The 'Manly Englishman' and the 'Effeminate Bengali' in the Late Nineteenth Century. Manchester: Manchester University Press, 1995.

Skinner, Quentin. The Foundations of Modern Political Thought, Volume I: The Renaissance. Cambridge: Cambridge University Press, 1978. 
Smith, David E. "Patronage in Britain and Canada: An Historical Perspective." Journal of Canadian Studies 22:2 (1987): 34-54.

Smith, Keith D. Liberalism, Surveillance, and Resistance: Indigenous Communities in Western Canada, 1877-1927. Athabasca: AU Press, 2009.

Steedman, Carolyn. Dust: The Archive and Cultural History. New Brunswick, New Jersey: Rutgers University Press, 2002.

Stein, Jeremy. "Time, space and social discipline: factory life in Cornwall, Ontario, 1867-1893.” Journal of Historical Geography 21:3 (1995): 278-299.

Steinmetz, George, editor. State/Culture: State Formation after the Cultural Turn. Ithaca: Cornell University Press, 1999.

Stewart, Gordon T. "John A. Macdonald's Greatest Triumph.” Canadian Historical Review 63:1 (1982): 3-33.

_ _ _ - The Origins of Canadian Politics: A Comparative Approach. Vancouver: UBC Press, 1986.

Stokes, Eric. The English Utilitarians in India. Oxford: Clarendon Press, 1959.

Sutherland, Gillian, editor. Studies in the Growth of Nineteenth-Century Government. London, Routledge and K. Paul, 1972.

Sweeny, Alastair. George-Etienne Cartier. Toronto: McClelland and Stewart, 1976.

Taylor, Graham D., and Peter A. Baskerville. A Concise History of Business in Canada. Toronto: Oxford University Press, 1994.

Taylor, Martin Brook. Promoters, Patriots, and Partisans: Historiography in NineteenthCentury English Canada. Toronto: University of Toronto Press, 1989.

Tillotson, Shirley. Contributing Citizens: Modern Charitable Fundraising and the Making of the Welfare State, 1920-66. Vancouver: UBC Press, 2008.

Tosh, John. A Man's Place: Masculinity and the Middle-Class Home in Victorian England. New Haven: Yale University Press, 1999.

Trevelyan, Humphrey. The Indian We Left Behind. London: Macmillam London Limited, 1972.

Underhill, Frank H. The Image of Confederation. Toronto: The Hunter Rose Company, 1964. 
Van Die, Marguerite, editor. Religion and Public Life in Canada: Historical and Comparative Perspectives. Toronto: University of Toronto Press, 2001.

_ _ _ Religion, Family and Community in Victorian Canada: The Colbys of Carrollcroft. Montreal and Kingston: McGill-Queen's University Press, 2005.

Wallace, David Foster. Consider the Lobster and other Essays. New York: Little, Brown and Company, 2006.

_ — . The Pale King. New York: Little, Brown and Company, 2011.

Walsh, John C. "Review of The Rule of Freedom, The Victorian Eye, and Spaces of Colonialism." Urban History Review/ Revue d'histoire urbaine 38:1 (2009): 3941.

- - — and Steven High. "Rethinking the Concept of Community." Histoire sociale/ Social History 32:64 (1999): 255-273.

Warsh, Cheryl Krasnick, ed. Drink in Canada: Historical Essays. Montreal and Kingston: McGill-Queen's University Press, 1993.

Welter, Barbara. "The Cult of True Womanhood." American Quarterly 18:2 (1966): 151-74.

Whitaker, Reg. "Between Patronage and Bureaucracy: Democratic Politics in Transition.” Journal of Canadian Studies 22:2 (1987): 55-71.

_ - - The Government Party: Organizing and Financing the Liberal Party of Canada, 1930-58. Toronto: University of Toronto Press, 1977.

Wilton, Carol. Popular Politics and Political Culture in Upper Canada, 1800-1850. Montreal and Kingston: McGill-Queen's University Press, 2000.

Wiseman, Nelson. In Search of Canadian Political Culture. Vancouver: UBC Press, 2007.

Young, Brian. George-Etienne Cartier: Montreal Bourgeois. Montreal and Kingston: McGill-Queen's University Press, 1981.

_ - _ . The Politics of Codification: The Lower Canadian Civil Code of 1866. Montreal and Kingston: McGill-Queen's University Press, 1994.

Zeller, Suzanne. Inventing Canada: Early Victorian Science and the Idea of a Transcontinental Nation. Toronto: University of Toronto Press, 1987. 


\section{Unpublished Theses and Dissertations}

Grittner, Colin J. 'A statesmanlike measure with a partisan tail:' The Development of the Nineteenth-Century Dominion Electoral Franchise. M.A. Thesis. Ottawa: Carleton University, 2009.

Horner, Dan. Taking to the Streets: Crowds, Politics and Identity in Mid-Nineteenth Century Montreal. PHD Dissertation. Toronto: York University, 2010. 